Florida International University FIU Digital Commons

$3-22-2018$

\title{
Dynamics of Iranian-Saudi Relations in the Persian Gulf Regional Security Complex (1920-1979)
}

Nima Baghdadi

Florida International University, nbagh001@fiu.edu

DOI: $10.25148 /$ etd.FIDC006552

Follow this and additional works at: https:// digitalcommons.fiu.edu/etd

Part of the International Relations Commons, and the Other Political Science Commons

\section{Recommended Citation}

Baghdadi, Nima, "Dynamics of Iranian-Saudi Relations in the Persian Gulf Regional Security Complex (1920-1979)" (2018). FIU Electronic Theses and Dissertations. 3652.

https://digitalcommons.fiu.edu/etd/3652 


\title{
FLORIDA INTERNATIONAL UNIVERSITY \\ Miami, Florida
}

\section{DYNAMICS OF IRANIAN-SAUDI RELATIONS IN THE PERSIAN GULF REGIONAL SECURITY COMPLEX}

$(1920-1979)$

\author{
A dissertation submitted in partial fulfillment of the \\ requirements for the degree of \\ DOCTOR OF PHILOSOPHY \\ in \\ POLITICAL SCIENCE \\ by
}

Nima Baghdadi 
To: Dean John F. Stack

Steven J. Green School of International Relations and Public Affairs

This dissertation, written by Nima Baghdadi, and entitled Dynamics of Iranian-Saudi Relations in the Persian Gulf Regional Security Complex (1920-1979), having been approved in respect to style and intellectual content, is referred to you for judgment.

We have read this dissertation and recommend that it be approved.

Ralph S. Clem

Harry D. Gould

Naisy Sarduy

Eric Lob

Benjamin Smith

Mohaddin Mesbahi, Major Professor

Date of Defense: March 22, 2018

The dissertation by Nima Baghdadi is approved.

Dean John F. Stack

Steven J. Green School of International and Public Affairs

Andres G. Gil

Vice President for Research and Economic Development and the Dean of the University Graduate School

Florida International University, 2018 
(C) Copyright 2018 by Nima Baghdadi

All rights reserved. 


\section{DEDICATION}

This is dedicated to my parents, Kimberly and Ascher. 


\section{ACKNOWLEDGMENTS}

I would like to begin by gratefully acknowledging the guidance, support and encouragement I received from my committee members. I extend my gratitude to Dr. Clem, Dr. Gould, Dr. Smith, Dr. Sarduy and Dr. Lob for committing to serve in my dissertation committee, guiding me throughout the way, keeping me motivated during this draining process, and helping me thrive both academically and personally. My special gratitude goes to my dissertation chair, Dr. Mesbahi for his patient mentorship, enthusiastic support, and compassionate care. Words cannot convey how blessed I feel to have had the opportunity to work with a mentor that is admittedly a father figure to me. I would not exaggerate if I said you made me a better person. I will be eternally grateful.

Also, I would like to thank all of our administrative staff at the Department of Politics and International Relations, specifically Martha Rodriguez, Maria Gil, and Maria Wilkinson-Diaz for their unwavering support during my career. I want to specially thank Maria Wilkinson-Diaz who on several occasions helped me put out fires along the way. You never hesitated to go above and beyond to help me personally and professionally. I look forward to years of friendship with you.

Ultimately, I want to humbly extend my sincerest appreciation to my parents, without whose sacrifice on many levels, I would not be here. You always guided me with your wise counsel and helped me overcome the hurdles along the way. You always trusted me and my choices, supported me unconditionally, and selflessly dedicated all you could to my success. I will be forever indebted. I owe a great debt of gratitude to my wife, Kimberly, for patiently bearing with all the difficulties of this whole process, for 
being understanding, loving and supportive. You were a caring companion and true cheerleader. You strongly supported my passion and never let me down. There are much brighter days ahead of us. I look forward to them. 


\section{ABSTRACT OF THE DISSERTATION}

DYNAMICS OF IRANIAN-SAUDI RELATIONS IN THE PERSIAN GULF REGIONAL

\section{SECURITY COMPLEX}

(1920-1979)

by

Nima Baghdadi

Florida International University, 2018

Miami, Florida

Professor Mohiaddin Mesbahi, Major Professor

This dissertation is an exploration of the dynamics of Iranian-Saudi relations from the earliest days of their encounter in the 1920s through 1979 Islamic Revolution in Iran. This is a period in the relations of the two states that has rarely been the subject of intellectual inquiry in the existing literature. This present research provides an analytical historiography of Iranian-Saudi relations with an aim to examine the elements constituting the dynamics of their relations. This is attained by contextualizing the milestones of Iranian-Saudi relations, triangulating historical accounts to identify the narrative among alternatives that best fits the meaningful causal processes explaining continuity and change, and weighing the impacts of factors playing a role in any given period of the Iranian-Saudi relations. 


\section{TABLE OF CONTENTS}

CHAPTER

PAGE

I INTRODUCTION 1

Literature Review $\quad 5$

Method $\quad 8$

Structure of the Project $\quad 9$

II STATE-SOCIETY RELATIONS IN IRAN AND SAUDI 15

ARABIA

The Idea of the State: Iran's Major Security Commodity Saudi 16

Arabia's Raison D'etre: A Challenge to the Authority of the 22

House of Saud

Assessment 35

III $\quad$ EARLY ENCOUNTERS AND THE RISE OF MUTUAL 37

SUSPICION (1924-1929)

1924 Khūzestān Rebellion $\quad 37$

A Brief History of Khūzestān and Arab Settlements in this 37

Region

Sheikh Khazal at the Clutch of the British Interests in the Great 39

Game

Sheikh Khazal's Rise to Power and Quest for Autonomy 46

The Rise of Reza Khan to Power 49

How Abdul Aziz Perceived the Developments in Persia 53

1927 Treaty of Jeddah: Foiling Iran's Claim to Bahrain and the 54

Resulting Increase in Mutual Skepticism

1929 Treaty of Friendship: Saudi's Unilateral Appeasement of $\quad 60$

Iran

IV IRANIAN-SAUDI RELATIONS IN THE 1930s: A CURIOUS

CASE OF DISREGARD IN FOREING POLICY Ontological

Security and Saudi Arabia's Quest for Regional Acknowledgement

Iran Entangled in Great Power Politics

Iran Facing Russia's Aspirations and the Communist Fervor Iran 69

Facing Britain's Aspirations and Entrenched Interests 70 
Germany as a Balancer, the Final Years of Reza Shah's Reign 96

Anti-Arab Sentiments: The Fate of Aryans Rests Elsewhere 99

$\begin{array}{ll}\text { Conclusion } & 108\end{array}$

V

WWII-STIRRED SHIFT OF POWER BALANCE AND

111

THE APILLOVER EFFECT OF NASSERISM AND

ARAB-ISRAELI CONFLCT (1944-1960)

1944 Test of the Treaty of Friendship, Halting of Diplomatic

Relations at a Hajj Incident

Post-War Context and International Security

International Security and Where Iran Fit in the United States'

Strategic Thinking

International Security And Where Saudi Arabia Fit In The

United States' Strategic Thinking

1951 Iranian Recognition of Israel

1951 Nationalization of Oil and 1953 CIA Coup in Iran

1953 - The Succession of King Saud and Disarray in Saudi

Foreign Policy

1955 - The Problematique of the Baghdad Pact

Nasserism, 1956 Suez Canal Crisis and the Sinai War

DEVELOPMENT OF AN IRANIAN-SAUDI

1979)

Factors Capturing the Essence of the Period 1962-1979

Key Features of King Faisal's Reign 1964-1975

Iranian-Saudi Encounters during King Faisal's Reign

1967 Arab-Israeli War

1962-1969 Yemeni War

186

Territorial Disputes in Anticipation of the British Withdrawal

from the Region

1973 Iranian-Saudi Coordination Against Iraqi Seizure of

Kuwaiti Outposts

1973 Yom Kippur/Ramadan War and Oil Embargo

Iran-Iraq Border Dispute/ 1975 Algiers Agreement

212

Iranian-Saudi Relations during King Khalid Reign

215

Hallmarks of King Khalid Reign

Iranian-Saudi anti-Communist Collaboration within the

Framework of Safari Club

Saudi's Perception of the Tumultuous Year Leading to the

Islamic Revolution in Iran 


\section{Chapter I}

\section{$\underline{\text { INTRODUCTION }}$}

A characteristic of the contemporary global politics is its "regional flavor."1 Two waves of regionalism are historically identifiable. The first wave began in the 1950s and continued into the 1970s. The still-ongoing second wave which is referred to as "new regionalism"2 started in the mid-1980s. ${ }^{3}$ Some scholars contend that "significant periods of economic regionalism" occurred in the interwar period and then only in the $1980 \mathrm{~s},{ }^{4}$ while Acharya and Johnston maintain that "regionalism has been a consistent feature of the global security and economic architecture since World War II."5

Security studies at the regional level is profoundly indebted to the various phases of decolonization specifically in the 1960 s and the end of the Cold War. ${ }^{6}$ Decolonization put an end to European imperialism and ushered in national states and sovereign equality. Such rough equality replaced inequalities characteristic of the colonial era. This

\footnotetext{
${ }^{1}$ Mark Beeson, M. "Rethinking Regionalism: Europe and East Asia in Comparative Historical Perspective,” Journal of European Public Policy, 12.6 (2005): 969-985.

${ }^{2}$ Michael Keating, The New Regionalism in Western Europe: Territorial Restructuring and Political Change (Cambridge University Press, 1998); Wilfred J. Ethier, "The New Regionalism," The Economic Journal, 108, 449 (1998): 1149-1161.; Bjorn Hettne, "Globalization and the New Regionalism: The Second Great Transformation." Globalism and the New Regionalism, 1(1999): 1-24.

${ }^{3}$ Jagdish Bhagwati, "Regionalism and Multilateralism: An Overview," New Dimensions in Regional Integration 22 (1993).

${ }^{4}$ Michael Kitson, \& Jonathan Michie. Trade and Growth, a Historical Perspective: From Managing the Global Economy (Oxford University Press. 1995).

${ }^{5}$ Amitav Acharya \& Alistair Ian Johnston, Crafting cooperation: Regional International Institutions in Comparative Perspective (Cambridge University Press, 2007), 18.

${ }^{6}$ Peter J. Katzenstein, "Re-examining Norms of Interstate Relations in the New Millennium," Kuala Lumpur: Paper for the 14th Asia-Pacific Roundtable, 2000); Patrick Morgan, "Regional Security Complexes and Regional Orders," in David Lake and Patrick Morgan, ed. Regional Orders: Building Security in a New World (Penn State University Press, 1997), 6-7.
} 
transformative shift had important ramifications for politics and security studies.

Regionalism was revived once the grand ideological rivalry between the two superpowers declined in the closing years of the Cold War. ${ }^{7}$ While some scholars doubt this thesis, ${ }^{8}$ the pervasive belief holds that regionalism is highly indebted to the end of the Cold War. The end of the Cold War ensued by weakening of global security arrangements, reduced the penetrative capacity and appetite of the superpowers considerably. The loss of power and appetite on the part of superpowers to actively engage in different world regions provided regional actors with more room to maneuver, exercise their sovereignty and quest for regional domination. ${ }^{9}$ In the absence of the great power influence, the new environment provided a fertile ground for a new international system wherein regional arrangements could assume greater importance. ${ }^{10}$ With the end of an era when the exigencies of superpower politics would condition regional affairs, states realized that they could conduct their regional security affairs and international alignments with greater liberty.

\footnotetext{
${ }^{7}$ Louise Fawcett, "Exploring Regional Domains: A Comparative History of Regionalism.” International Affairs, 80.3 (2004) 429-446.

${ }^{8}$ See Arthur Stein, and Steven E. Lobell, "Geostructuralism and international politics: the end of the Cold War and the regionalization of international security" in David A. Lake and Patrick M. Morgan, Regional Orders: Building Security in a New World (University Park: Pennsylvania State University Press, 1997) 101-122; Michael Mastanduno, "A realist view: Three images of the coming international order." International Order and the Future of World Politics, 1990, 19-40.; William C. Wohlforth, "The stability of a unipolar world." International security, 24, no. 1 (1999): 5-41.

${ }^{9}$ Barry Buzan, People, states \& fear: an agenda for international security studies in the post-cold war era (Ecpr Press, 2008); Richard Rosecrance, "Regionalism and the Post-Cold War Era." International Journal 46, no. 3 (1991): 373-393; Andrew Hurrell, \& Louise Fawcett, "Regionalism and international order?" in Andrew Hurrell, \& Louise Fawcett, eds. Regionalism in world politics: Regional organization and international order (Oxford University Press, 1995); Edmond J. Keller, "Rethinking African Regional Security." Regional Orders: Building Security in a New World (1997): 296-317.; Barry Buzan, and Gerald Segal. "The rise of "lite" powers: a strategy for the postmodern state." World Policy Journal 13, no. 3 (1996): 1-10.; Stein \& Lobell, "Geostructuralism”; David J. Pervin, "Building Order in Arab-Israeli Relations: From Balance to Concert." Regional orders: Building security in a new world (1997): 271-95.

${ }^{10}$ Buzan, People, states \& fear.
} 
Whether regions' rise in importance after the Cold War occurred due to an insideout thrust in the absence of the grand ideological struggle or, as Katzenstien maintains, as the result of the encouragement by the United Stated perceiving regions as foundational pieces to the global security puzzle under the aegis of "American imperium,"11 the unequivocal fact is that regions matter both in policy and academic debates.

Among all the regions of the world, the Middle East is perhaps the most volatile. The Persian Gulf as a sub-region of the Middle East stands further out due to its political, economic, strategic, and geopolitical complexities. The geostrategic significance of the region, the fact that it hosts unresolved historical multi-dimensional disputes among its littoral states, the existence of serious human security issues with upward pressure on the states' capacity to control, the weakness of regional governance institutions, the uncertainty caused by non-state actors and social dynamics; and the long-lasting presence of outside powers in it encourage intellectual probe into the security dynamics of this fascinating setting.

This research is an analytical historiography of Iranian-Saudi security dynamics from 1920s through 1979. This research begins with the 1920s because the earliest encounters between Persia and Saudi Arabia — which was in the making — dates back to these years. Also, the 1979 Islamic Revolution has been decided to offer a logical cut-off point for the scope and purpose of this research. The post-revolutionary Iran underwent a massive overhaul in its foreign policy concerns and practices, discouraging any juxtaposition of these two essentially distinct eras in one enterprise as large as a

\footnotetext{
${ }^{11}$ Peter J. Katzenstein, A world of Regions: Asia and Europe in the American Imperium (Cornell University Press, 2005). Katzenstein argues that the United States made "regionalism a central feature of world politics" so that it would serve its imperial interests across the globe.
} 
dissertation. The present research is informed by the pursuit of five themes/inquiries. First, this research problematizes mutual/dialectic construction of security perceptions, practices and policies between Iran and Saudi Arabia whenever such interconnectedness was historically demonstrable. Second, in this analytical historiography of Iranian-Saudi security relations, the notion of "agency" is traced and examined. An assessment of the degree to which players can manifest agential capacity, will and power within the rigidity of regional configurations is important in regional security studies. This research aims to challenge the notion that regional players simply lacked any meaningful agency prior and during the Cold War. This research contends that beyond British hegemony in the Persian Gulf region prior its withdrawal, and the Cold War grand superpower ideological rivalry, the Iranian-Saudi relations reflect considerable agential qualities. These qualities are typically overlooked in the literature that accentuates the role of the great powers in determining the course of events in the regions, and discounts regional conflicts outside the Cold War grand rivalry as simple microcosms of the overarching ideological struggle. The present research analyzes the role of super/great powers in the region in terms of regional players' response to their presence or quest for having a presence in the region. This approach will provide a better insight on the impact of outside forces on the regional security dynamics. ${ }^{12}$ Third, this research provides a fresh assessment of Iranian-Saudi security relations in the Western orbit during various phases of the Cold War. This theme is predicated on the notion that superpower clientele is not monolithic, rather there are

\footnotetext{
${ }^{12}$ Following Andrew Hurrell, this research bears that regions are not self-contained spaces and immune from outside pressures. According to Hurrell, indirect hegemonic influences are worth the inquiry in this regard. Some of empirical scholarship with this perspective are Ojendal 2004; Jones and Smith 2007; Ravenhill 2009. Acharya's quite comprehensive perspective about the role of outside powers in regional systems is perhaps the closest to what serves as the compass in this research.
} 
various degrees and types of clientelism, determining the extent to which regional players were willing to give up their autonomy in decision-making to their superpower patrons. During the interwar period and then the Cold War, Iran and Saudi Arabia represented two distinct approaches to the great/superpowers, causing, at times, a divergence in their policies toward the region and beyond. Fourth, this research investigates how the IranianSaudi relations in this period were influenced by the domestic vulnerabilities of either side. Domestic vulnerabilities can render a neighbor with the potential of posing a threat corresponding to those vulnerabilities as a structural threat. The role such vulnerabilities

- caused by the maladies of state-society relations in either country - played in determining the direction of Iranian-Saudi relations constitutes another major problematique in this research. Fifth, this study provides the historical context of some faultines to which the complexity of Iranian-Saudi relations are conveniently, yet erroneously reduced. It is important to identify the context and mechanism through which the Shiite-Sunni or Persian-Arab divide informs the relations between the two states among other factors, and avoid essentializing these relations by reducing them to the operation of these cleavages.

\section{Literature Review}

Due to a long-lasting tradition within the discipline that biased toward great power politics, the literature that examine the security dynamics among non-great powers within the bounds of regions is tenuous. The discipline of International Relations was developed after the WWII and within the context of the Cold War. In this environment, the primary concern of academics was the analysis of great power politics which led to massacres of 
the two world wars and/or the ideological rivalry of the two superpowers on the global scale. Academics in concert with politicians viewed regions of the world as stages for the colonial rule of the old European powers or the ideological/military maneuvers of the Cold War superpowers. In spite of that bias, regional level is where most of the action takes place for most of the states. While only few great powers have such massive capabilities which enable them to pursue their wide-range security interests over the whole planet or a substantial portion of it, almost all other states with limited capabilities largely confine their security interests and practices to their near neighbors. ${ }^{13}$

Several themes guide academic literature on the Iranian-Saudi relations either directly or within the broader inquiry on the Middle Eastern politics. These themes are atheoretical survey of Iranian-Saudi relations in the context of great power politics (Halabi 2009; Chubin \& Zabih 1974; Maoz 2013; Mirhosseini 2011; Keynoush 2016; Legrenzi 2013; Kraig 2006; Mangold 2013; Cooper 1997; Sciolino 1991; Neuman 1996); IranianSaudi relations as influenced by the geopolitics of the region or the regional order (Mojtahedzadeh 1998, 2013; Legrenzi 2013; Herrmann \& Ayres 1997; Graz 1990; Chubin and Tripp 2014; Potter 2002; Fox et. al. 2006) Iranian-Saudi relations as defined by the problematique of oil (Golub 1985; Glaser \& Kelanic 2016; Cooper 2012; Hurewitz 1975; Quandt 1981; Crystal 1995; Herrmann \& Ayres 1997); atheoretical account of historical relations and/or analytical account of mutual awareness (Cleveland 2012; Entessar 1984; Abrahamian 1982; Badeeb 1993; Kawtharni \& Haseeb 1998; Anthony 2015; Amir Ahmadi \& Entessar 1993; Al-Saud 2003; Ahmadi 2007; Weller 1993; Ehteshami 2003; Chubin and

\footnotetext{
${ }^{13}$ Barry Buzan, \& Ole Weaver. Regions and powers: The structure of international security. (Cambridge: Cambridge University Press, 2003).
} 
Tripp 2014; Afary 1996; Afkhami 2009; Ansari 2003; Mostyn 1991; Wilson 2011); Iranian-Saudi relations in light of the Persian Gulf conflicts, wars and militarization (Orgill 1995; Mughissudin 1977; Graz 1990; Gordon and Trainor 1995; Freedman and Karsh 1993; Cordesman and Gold 2014; Kennedy 1975; Gordon 1981; Mccuen 1987; Tripp and Chubin 1988; Pelletiere 1992; O’Neill 1992; Frank 1992; Rajaee 1993; Askari et. al 2010); Iranian-Saudi relations as influenced by the presence of foreign powers and/or their diplomatic/military strategy in the region (DeNovo 1963; Bromley 1991; Hudson 1996; Hunter 2010; Hurewitz 1972; Baram 1978; Adelson 1995; Nakhleh 1982; Kupchan 1987; Gause 1985; Dunnigan and Macedonia 1993; Miller 1980; Mangold 2013; Koury \& Nakhleh 1979; Joshua \& Gibbert 1969; Sick 1983; Acharya 1989; Kraig 2006; Cole 2003); Iranian-Saudi relations in light of their distinctive foreign policy making (Goldberg 1986; Fraser 1997; Brzegar 2008; Afrasiabi 1994; Ramazani 1972; Mirhosseini, S. M., \& Sandhu 2013; Barzegar 2008; Taheri 1975; Afrasiabi 1994; Boroujerdi 1996; Marschall 2003; Chubin and Litwak 2003); the role of Islamic intra-faith divisions in defining the IranianSaudi relations (Louer 2008; Buchan 2015; Dawisha 1983; Piscatori 1983; James 1984; Nasr 2004; Nakash 2003; Jones 2006; Kramer 1987; Bill 1984; Cole and Keddie 1986); and the Iranian-Saudi relations as a subset to the international relations of the Persian Gulf/ Middle East (Hinnebusch 2010; Dunnigan \& Macedonia 1993; Byman 2003; Moshaver 2012; Burrell 1972; Anthony 1981; Amirsadeghi 1981; Moshaver 2012; Kamrava 2011; Hurewitz 1956, 1972; Hunter 2010; Gause 2009; Halliday 2005; Lawson 2006; AdibMoghaddam 2006; Bayman and Wise 2003).

While there are overlapping between the scope of this research and some of the themes appearing in the literature on the Middle East and the Persian Gulf, this research is 
distinguished by its assessment of the Iranian-Saudi security dynamics with an approach that captures "a complex interplay of local, regional, and global forces, simultaneously involving states as well as non-state, market, and societal actors."14

\section{Method}

Process Tracing is the method that informs this study. Process Tracing is a distinct method in qualitative research that has recognition and widespread use among political scientists. Process Tracing involves research where, "the cause-effect link that connects independent variable and outcome is unwrapped and divided into smaller steps; then the investigator looks for observable evidence of each step." ${ }^{15}$ With this method, one can "peer into the box of causality to locate the intermediate factors lying between some structural cause and its purported effect." ${ }^{" 16}$

Process Tracing enables an investigator to narrow the list of potential causes for an outcome down to one or few causal paths and put aside alternative, yet less consistent, explanations. Methodologically, Process Tracing traces the causal process in a very specific, theoretically informed way; although some variations of the method tend to be less theoretical or atheoretical altogether. In more theoretically informed variant of the

\footnotetext{
${ }^{14}$ Samuel S. Kim, "Northeast Asia in the local-regional-global nexus: Multiple challenges and contending explanations." The International Relations of Northeast Asia, 41 (2004) 11.

${ }^{15}$ Stephen Van Evera, Guide to methods for students of political science. (Ithaca: Cornell University Press. 1997); Andrew Bennett, 'the mother of all "isms": Organizing political science around causal mechanisms.' in Ruth Groff, Revitalizing Causality: Realism about Causality in Philosophy and Social Science (Routledge, 2008) 205-219; Jeffrey T. Checkel, "Process tracing." In D. Prakash, \& A. Klotz, Qualitative methods in international relations, (Palgrave Macmillan UK, 2008) pp. 114-127; Jeffrey T. Checkel, "Tracing causal mechanisms." International Studies Review 8, no. 2 (2006) 362-370; Alexander L. George, and Andrew Bennett. Case studies and theory development in the social sciences. (MIT Press, 2005).

${ }^{16}$ John Gerring, "Single-outcome studies: A methodological primer." International Sociology 21, no. 5 (2006): 707-734.
} 
method, the researcher looks for a series of theoretically predicted intermediate steps to establish the verity or falsity of an alleged path of causality. This method overwhelmingly uses qualitative data that are usually garnered from various resources including but not limited to historical memoirs, expert surveys, interviews, press accounts, and documents. ${ }^{17}$

Process Tracing equips the researcher with a diagnostic perspective. With such outlook, the research can differentiate between those pieces of evidence that may constitute a major step on the causality chain and those with unsubstantial contribution to the correlation between the dependent and independent variables. Benefiting from the rigor of this method, a researcher will eventually support a hypothesis and overturns alternative competing hypotheses. This method could be effectively used to account for the deviant cases with outcomes that defy theoretical predictions or explanations.

In this research, the sequences and mechanism in the unfolding of hypothesized causal processes regarding Iranian-Saudi security interconnectedness in the Persian Gulf region is examined. This is not a one-directional approach since the causality chain is also examined backward from the observed outcomes to potential causes. Such two-directional examination of an apparently existing causal relationship between the variables helps with testing the theory against evidence and modification of it, if necessary. Through this process, the overlooked variables affecting causality chains will be uncovered.

\section{STRCUTRE OF THE PROJECT}

This dissertation is by and large structured periodically; however, a chapter that contains an overall analysis of the faultlines in state-society relations in Iran and Saudi

\footnotetext{
${ }^{17}$ Checkel, "Process Tracing."
} 
Arabia precedes the periodic organization of the rest. The logic behind including this chapter lies in the necessity of extrapolating the potential impacts of the states' vulnerabilities at the domestic level of analysis. These vulnerabilities determine the fears and threat perception of a state. These fears stemming from domestic politics might render other states in the region into structural threats even in the absence of hostile intentions on their parts. ${ }^{18}$

Chapter three titled "Iran-Saudi Arabia (1924-1929): Early Encounters and the Rise of Mutual Suspicion" provides a historical account of the very first encounter between Iran and Saudi Arabia which occurred as early as the mid-1920s, almost a decade before the official establishment of the Kingdom of Saudi Arabia in 1932. This encounter was stirred by the suppression of Sheikh Khazal's rebellion in Khūzestān. The context of the encounter, Saudis' perception of Persia created thereof, and the 1927 Treaty of Jeddah and 1929 Treaty of Friendship as manifest practical responses of the Saudi king in face of the growing Persia's power are analyzed in this chapter.

The fourth chapter, titled "Iranian-Saudi Relations in the 1930s: A Curious Case of "Disregard" in Foreign Policy" looks at a puzzling period of Iranian-Saudi relations. From 1932 (official establishment of Saudi Arabia) through the Second World War years, Persia pursued a policy of avoiding any engagement with infantile Saudi Arabia. In order to give presence to Saudi entity in the region and reaffirm their assumed identity, Saudis desired to engage Iran but much to their disappointment, Persia did not reciprocate that desire, making a curious case of 'disregard' in foreign policy. This chapter will make the case that

\footnotetext{
${ }^{18}$ Ole Wæver, "Conflicts of vision - visions of conflict.” In Wæver, Ole, Lemaitre, Pierre, \& E. Tromer, eds., European polyphony: Beyond East-West confrontation (London: Macmillan., 1989)
} 
geopolitically, Persia's primary concern rested with the threats posed by Russia and Britain. To be more precise, there was neither any real or perceived threat posed by the neighboring Arab states that would amount to that level of gravity, nor these states could be part of any solution to Persia's affliction with Russo-British interventionist policies. Reza Shah's hallmark of foreign policy during his reign was playing Russia and Britain against one another. In fact, nothing amounted to that level of urgency in Iranian foreign policy making than to find a way to rid the country from the menace of foreign influence or at least ameliorate its impact by balancing the two powers. In these calculations, there was no place for the infantile state of Saudi Arabia. Aside from the geopolitical aspect, the case will be made that there was an ideational/geo-cultural layer of analysis that gradually dominating narrative of Iranian nationalism predicated on a romanticized notion of glorious pre-Islamic Persia which was essentially anti-Arab. This narrative informed Reza Shah's European-style modernization and his pursuit of the Persian fate in relation with Europeans and not "racially sub-par Arabs." The (re)construction of Iran's classical past as an epoch in which the nation existed in its homogeneous and unsullied form was the foundation of the nationalist discourse that called for a return to pre-Islamic Iranian culture and an appropriation of racialist Aryanism. This essentially anti-Arab discourse defined Reza Shah's foreign policy toward Arab states, specifically Saudi Arabia.

The fifth chapter which focuses on the time period between 1944 through 1962 is titled "WWII-Stirred Shift of Power Balance and the Spillover effect of Nasserism and Arab-Israeli Conflict." With a noticeable shift in the regional balance of power during and immediately after the Second World War, the Iranian-Saudi relations entered an era marked by ever growing complexity. It is in this period that the United States enters the regional 
politics of the region not only because the United States needed raw material for its energyintensive economic model, but also because the United States realized that the entrenchment of Soviet power" in the Persian Gulf and possible Soviet disruption of oil flow from the region would have caused a "decisive shift in the world balance," and "the economy of the free world," leading to the ultimate "triumph [of the Soviet Union] throughout Asia, Africa, and Europe. Therefore, this chapter looks at where Iran and Saudi Arabia fit in international politics and Western strategic thinking. In this regard, the architecture of the 1955 Baghdad Pact strained the Iranian-Saudi relations. Furthermore, this period entailed signs that Iranian-Saudi relations are not immune to the spill-over effects of adjacent regions. In fact, Iran's de facto recognition of Israel in 1951 due to its strategic potentials, the rise of charismatic Gamal Abdel Nasser who espoused Third World neutralism and advocated Pan-Arab empire the Atlantic to the Persian Gulf under his leadership, and the 1956 Suez Canal Crisis and the Sinai War proved that Iranian-Saudi relations are notably sensitive to factors exogenous to the region. In addition, this chapter will cover two major developments in Iran and Saudi Arabia which could have had immense impacts on the relations of the two states. The first set of these developments that unfolded in the early 1950s entailed the 1951 Iranian nationalization of oil, Shah's departure of the country and the 1953 CIA-led coup to overthrow the democraticallyelected government of the Mosaddeq and reinstate the fleeing king. The second set of developments which unfolded in the aftermath of the passing of King Abdul Aziz swirled around the controversies, royal family infighting, economic crisis, and disarray in foreign policy as the result of King Saud's ineptitude and ambitions. Why Iran and Saudi Arabia 
did not seize the political opportunity to exert pressure on one another was an interesting feature of this period.

The sixth chapter, titled "the Development of an Iranian-Saudi Alignment: Cautious and Curtailed," analyzes the relatively amicable Iranian-Saudi relations between 1962 and 1979. Such amicability in spite of a variety of factors which could potentially distance the two states shapes the puzzle of the Iranian-Saudi relations in this period. Among the factors which could have negatively impacted Iranian-Saudi relations, one can note Iran's persistence with its ties with Israel, Iranian-Arab territorial disputes, change in Saudi leadership with the assassination of King Faisal, withdrawal of Britain from the region and a power vacuum created thereof, Iran's demonstrable regional assertiveness and its rapid military build-up, contention over the sovereignty of Bahrain, etc. Two factors being Egyptian President Nasser and his pan-Arab ideology, and cooperative norms propagated by the Nixon Doctrine encouraged Iran and Saudi Arabia to pursue cautious political ties, in spite of disagreements and differences. This chapter makes the case that despite the relatively stable period in which Iran and Saudi Arabia could align their policies and tacitly cooperate on many levels, that cooperation did not spawn a radical change in the historical patterns of amity/enmity between the two states as Saudi Arabia and Iran never surmounted their mutually stigmatizing differences deeply embedded in their political cultures. In other words, while the facade of interactions between the two states in this decade alludes to cooperation, the convergence of policies between the two countries did not occur as the result of a genuine transformation in historical perceptions. The reason is to be sought in an exacerbated Arab-Persian divide which was pushed to the back of geopolitical considerations, yet limiting the extent of an Iranian-Saudi integration. 
The concluding chapter revisits the five themes informing this research in order to trace the patterns of amity and enmity in the Iranian-Saudi relations. This chapter captures almost 60 years of Iranian-Saudi relations along the lines of security interconnectedness, agential capacity and power of the players, great power influence and clientelism, domestically generated vulnerabilities, Shiite-Sunni schism, and eventually Arab-Persian divide. 


\section{CHAPTER II}

\section{$\underline{\text { STATE-SOCIETY RELATIONS IN IRAN AND SAUDI ARABIA }}$}

According to Buzan, examining the state-society relations can provide insight into domestically generated vulnerabilities that can have important repercussions for the regional security. ${ }^{19}$ In any analysis of regional security interconnectedness, it is important to identify domestically generated vulnerabilities and what they mean for either actual or perceived regional threats. An important set of such vulnerabilities is determined by the state-society relations enshrined in the idea of the state. Problematizing the interplay between the levels of sociopolitical cohesion of a nation-state on the one hand, and the type of security dynamics generated thereof on the other is essential to analyze security patterns in a particular region. ${ }^{20}$ The sociological cohesion of a nation-state affects the way a given state perceives security and where threats to that security originate. While these threats or (mis-)perception of threats emanate from the domestic politics of the states, vulnerabilities as such, real or imagined, define the state's security fears and their potential response. ${ }^{21}$

The Persian Gulf region is mostly comprised of states that rank low on the scale of sociopolitical cohesion. These states are rentier in nature and/or artificial products of decolonization. These factors can hollow out state-society relations from any substance

\footnotetext{
${ }^{19}$ Barry Buzan, \& Weaver, O. Regions and powers: The structure of international security. (Cambridge University Press, 2003) 51.

${ }^{20}$ Barry Buzan, People, state and fear. (New York: Harvester Wheatsheaf, 1991) 96-107; Stephen D. Krasner, Defending the national interest. (Princeton: Princeton University Press, 1978) 55-56; Kalevi J. Holsti, The state, war, and the state of war. (Cambridge University Press, 1996); Robert H. Jackson, Quasistates: Sovereignty, international relations, and the third world. (Cambridge University Press. 1990).

${ }^{21}$ Ole Wæver, "Conflicts of vision - visions of conflict," in Ole Wæver, et al. eds., European polyphony: Beyond East-West confrontation (London: Macmillan, 1989).
} 
and degrade it to a contractual façade, typically maintained by the state's heavy hand.

The following sections identify state-society faultlines in Iran and Saudi Arabia and how these faultlines may serve as sources of national insecurity. Identifying these dynamics would enable any investigator to understand where domestically originated vulnerabilities in Iran and Saudi Arabia rest, and if there are exchanged threats in response to those vulnerabilities.

\section{The Idea of the State: Iran's Major Security Commodity}

Annals of Iran's ancient history have a lot to reveal about the debates over contemporary Iranian identity and politics. In order to trace the evolutionary trajectory of Iran, Iranian nation, and Iranian nationalism, one has to go back to $550 \mathrm{BC}$ in Babylon, where Achaemenids, ${ }^{22}$ undeniable achievements on civilizational grounds left a hefty legacy for Iranian nationalist movements for centuries. Iranian nationalism began its maturation during the Sassanid era, notably manifested in the idea of Eranshahr, Kingdom of the Iranians. Eranshahr was not yet representative of what Anthony W. Marx refers to as a "collective sentiment of bounded solidarity or identity," 23 but it did connote a meaningful degree of ethno-territorial awareness, and a sense of belonging. ${ }^{24}$ Gherardo Gnoli suggests that the idea of Eran emerged in the Sassanid era, ${ }^{25}$ but the

\footnotetext{
${ }^{22}$ In the $6^{\text {th }}$ century BCE, Cyrus the Great united two Iranian tribes that had moved into the region in the $11^{\text {th }}$ and 10th centuries BCE to form the first great Persian Empire known as Achaemenian Empire.

${ }^{23}$ Anthony W. Marx, Faith in nation: exclusionary origins of nationalism. (Oxford University Press, 2005) 6.

${ }^{24}$ Shireen T. Hunter. Iran divided: the historical roots of Iranian debates on identity, culture, and governance in the twenty-first century. (Rowman \& Littlefield, 2014).

${ }^{25}$ Gherado Gnoli, The idea of Iran: an essay on its origin. (Rome, 1989) Seen in "Iranian Identity Perspectives" Encyclopedia Iranica, http://www.iranicaonline.org/articles/iranian-identity-i-perspectives retrieved on 11/08/2016.
} 
nexus of ethnicity-territory embodied in the concept of Eranshahr dates back to Achaemenid era. ${ }^{26}$ The romanticist view of the origin of Iranian nation is predicated on such an impressive repertoire of mythological traditions as well as glorious factual history in Iran. ${ }^{27}$

Modernist historians and political scientists who believe that the concept of "nation" is a modern construct typically refute the primordialist view of Iranian identity. Modernists entertain the idea that nations are artificial constructs engineered by the ruling classes, and such arrangement could not have existed before the birth of the modern nations. According to modernists, nations do not primordially exist, rather they are "invented." ${ }^{28}$ Accordingly, Bert Fragner, a modernist Iranologist, argues that modern Iranian national identity is radically divorced from Iranian historical past.

There is a third synthetic approach in identifying and assessing nations' trajectory of evolution and the emergence of nationalist sentiments. ${ }^{29}$ This approach has a historicizing perspective, to which the present research subscribes. Accordingly, nations are deemed as modern constructs and elites play an important role in orchestrating topdown nationalist projects, however, the long-term historical forces and processes in the formation of modern nations are equally important. Time plays an important role in the synthetic approach. Time serves as a bedrock for the emergence and development of

\footnotetext{
${ }^{26}$ Richard N. Frye, "The political history of Iran under the Sasanians." The Cambridge History of Iran 3, no. 1 (1983): 116-180.

${ }^{27}$ For the three narratives of the Iranian identity, refer to Ahmad Ashraf, "Hoviyat e Irani be se ravayat," [Iranian Identity, Three Narratives] Iran Nameh, vol. 24, no. 2 \&3 (Summer and Fall 2008)

${ }^{28}$ See Eric Hobsbawm. Nations and nationalism since 1780: programme, myth, reality. (Cambridge University Press, 1990).

${ }^{29}$ Among Iranologists favoring this view of nationalism, Ehsan Yarshater, Gherado Gnoli, Ann Lambton, Roy Mottahedeh, Fereydun Adamiyat, Shahrokh Meskoob, Mohammadreza S. Kadkani are notable.
} 
myths, memories, values and symbols. It is the 'time' that allows for peoples of various creeds, languages, classes and strata to go through identical historical experiences and as a result develop shared identities and pass on similar stories to their descendants.

During the Sassanids,${ }^{30}$ the pre-Islamic Iranian identity reached the height of its fulfillment. The pillars of the pre-Islamic Iranian identity were the appeal to a heroic past and the Zoroastrian tradition. ${ }^{31}$ However, the Arab invasion of Iran was a landmark development in Iranian history and identity. ${ }^{32}$ The Muslim conquest of Iran is perhaps the most important historical episode in Iran's history with tremendous formative significance for how the ideational landscape of Iran is shaped. The arrival of Islam was a watershed to the pre-Islamic Iranian identity. Alessandro Bausani, the prolific Italian orientalist, acknowledged the gravity of the matter, and concluded that the foundation of modern Iranian identity is the medieval Irano-Islamic culture, not the pre-Islamic Achaemenid image. ${ }^{33}$ The conquest of Iran by Arabs was a historical moment that introduced Islam as an enduring pillar of Iranian identity. ${ }^{34}$ Nevertheless, it is important to note the embrace of Islam by Iranians was not coupled by an embrace of the Arabs and

\footnotetext{
${ }^{30}$ Sassanids, established in 224 CE by Ardeshir Babakan, was the last Persian Empire before the Muslim conquest of Iran. Sassanids neighbored their arch rival the Roman-Byzantine Empire for over 400 years. The Sassanids is considered the peak of ancient Iranian civilization. Will Durant in his Age of Faith, (1950) acknowledges the outreach of Iran's cultural influence eastward into India, Turkestan and China, westward into Syria, Asia Minor, Constantinople, the Balkans, Egypt and Spain.

${ }^{31}$ Touraj Daryaee, "National history or Keyanid history? The nature of Sasanid Zoroastrian historiography." Iranian Studies28, no. 3-4 (1995): 129-141.

${ }^{32}$ Following the passing of Prophet Muhammad in 532 CE, Muslim armies attacked the Sassanid Empire and achieved major victories in Qadisiya in 637, and at Nahavand in 641 which led to the end of the Sassanid Empire in 651 and the eventual decline of Zoroastrianism in Iran.

${ }^{33}$ Alessandro Bausani, the Persians, from the Earliest Days to the Twentieth Century. (St. Martin's Press, 1971).

${ }^{34}$ Hamid Ahmadi, "Unity within diversity: foundations and dynamics of national identity in Iran." Critique: Critical Middle Eastern Studies 14, no. 1 (2005): 127-147.
} 
their culture, ${ }^{35}$ a sign indicative of the voluntary nature of that ideational shift. This was the beginning of centuries-long coexistence of two competing sources of identity in Iran. This coexistence was at times peaceful and at others confrontational.

In the medieval era, Arabo-Islamic and ethno-nationalistic sentiments based on the pre-Islamic Iran's traditions continued to serve as two competing sources of identity. Fast forward to the $16^{\text {th }}$ century, another important episode in the formation of Iranian national identity took place with the Safavids' enforcement of a hybrid of Iranian-Shiite identity. ${ }^{36}$ Following his conquest of Iran, King Ismail I. embarked on a systematic Shiization of the country, an initiative that was picked up by other Safavid kings succeeding him. The compatibility between Shiism and traditional Iranian values, arguably, resolved the centuries-long ideational confusion of commitment to Islam and loyalty to Iran. ${ }^{37}$ From the earliest days of Islam, Iran was the cradle for the Shiite thoughts but it was not until the Safavid era that Shiism entered as an ideational elements in the ethnic consciousness of the Iranians, leading to a transformational shift in the Iranian perception of "self." 38

\footnotetext{
${ }^{35}$ Morteza Motahari, Khadamat e Moteghabel e Eslam va Iran [Mutual Contributions of Islam and Iran,] (Sadra Publication, 1987).

${ }^{36}$ Safavid dynasty ruled Iran from 1501 to 1722 with a brief period of restoration from 1729 to 1736 . At their height (during the reign of Shah Abbas I 1587-1628), they controlled all of modern Iran, Azerbaijan, Bahrain and Armenia, most of Georgia, the North Caucasus, Iraq, Kuwait and Afghanistan, as well as parts of Turkey, Syria, Pakistan, Turkmenistan and Uzbekistan. The Safavids gradually declined and were conquered by Afghans in 1722 which initiated a decade of instability.

${ }^{37}$ See Mohammad Ali Hajilou, Rishehaye Tarikhi Tashayyo Dar Iran [Historical Roots of Shiism in Iran] (Majma e Jahani Shia Shenasi, 2007).

${ }^{38}$ Ahmad Karimi Hakkak, "Nejad, Mazhab, Zaban: Ta'ammoli dar se engareye ghomiyat dar Iran," [Race, Religion, Language: A Thought over the Three Elements of Iranian Ethnicity] Iran Nameh, vol.11, no.4 (fall, 1993).
} 
Shiism deeply influenced the collective identity and, by necessity, the political culture in Iran. Shiism fostered a national unity that overcame the divisions along ethnic lines between the Persians and other minorities, most notably, Turkic speaking populations who had lived in Iran since the destructive invasions by Turks ${ }^{39}$ and Mongols. ${ }^{40}$ These invasions had extensively shifted the country's linguistic and ethnic balance. The new ethno-religious identity of Iranians in a context of rising Ottoman Empire in West Asia and North Africa, the Gurkani Empire in India, ${ }^{41}$ and the Uzbeks in Central Asia — all adhering to Sunni Islam — helped Iran assume a distinct status among these political entities. Such distinct sense of collective identity was a determinative factor in preserving the political and territorial unity of Iran in the face of the Ottomans who had brought the Sunni Arabs under their rule.

It is correct that the introduction of Shiism in Iran might have created its own faultline of sectarian nature as some Iranian peoples like Kurds remained Sunnis; however, the unifying effect of Shiism in Iran over the centuries outweighs its divisive effect. The notion that religion may play a constructive role in the formation of ethnonational identities might be debatable, but at least in two phases of Iranian history, religion has appeared to act as a catalyst for fostering strong nationalistic sentiments.

\footnotetext{
${ }^{39}$ The Saljuq dynasty was an Oghuz Turk Sunni Muslim dynasty who established both the Saljuq Empire and Sultanate of Rum, which at their heights stretched from Anatolia through Iran. In the 11th century, the Saljuqs migrated from their ancestral homelands into mainland Persia, in the province of Khurasan, where they encountered the Ghaznavid Empire. The Saljuqs defeated the Ghaznavids and after the siege of Isfahan by Tughrol in 1050-51, they established the Great Saljuq Empire. Saljuq easily assimilated into the culture and practices of Persia and became Persianate.

${ }^{40}$ The invasion of Mongols in 1219 and then Tamerlane (born in a Turkicized tribe of Mongol descent) in 1381 destroyed a huge portion of Iran and extensively changed its ethnic and demographic landscape.

${ }^{41}$ Self-designated term for the Mongol Empire based in the Indian Subcontinent which was ruled by a Muslim Persinate dynasty of Turkic-Mongol origin. Mongols referred to themselves as Gurkani which literally meant "son-in-law" of Chengiz.
} 
Hobsbawm identifies these two phases as pre-modern Iran with the role of Zoroastrianism in the formation of the Iranian ethno-national identification in the Sassanid era, and the modern Iran with the contribution of Shiism at the time of the Safavids. $^{42}$

During the $19^{\text {th }}$ century, Iran entered the age of nation-building and nationalism with a longstanding legacy of historical awareness and cultural consciousness of its identity. Comparative historians of nationalism acknowledge that Iran was among the few nations that experienced the era of nationalism with a deep historical root and experience of recurrent construction of its own pre-modern identity. ${ }^{43}$ The modern era of Westernstyle ideas of nation and nationalism conveying the ideals of autonomy, unity and prosperity only reinforced the rich historical repertoire of Iranian identity, which has lasted to the present day.

The religio-nationalist ideational basis of Iran makes the idea of the state strong and resilient. This ideational basis is highly encompassing, if not overarching. The length of history in Iran dating back to the immemorial time has allowed for the formation of a riveting mélange of pre-Islamic nationalist identities and Islamic/Shiite proclivities that is palatable to the majority of people living in territorial Iran across ethnic, religious, and linguistic cleavages. Even those who may repudiate either Shiism or glorified pre-Islamic Iranian history as a source of identity usually does so by assuming heavier leaning toward the other end. In other words, most peoples within the territorial limits of the country, find themselves somewhere on the gridlock of Shi'ism and Iranian ethno-nationalist

\footnotetext{
${ }^{42}$ Hobsbawm, Nations and Nationalism, 69, 137.

${ }^{43}$ See ibid; Hugh Seton-Watson, "An enquiry into the origins of nations and the politics of nationalism." Nations \& States.: 563 (1977); Anthony D. Smith, The antiquity of nations (Wiley, 2004).
} 
sentiments. Most Iranians comfortably and proudly identify with the territorial Iran despite their political, social, and economic grievances, and discriminations that target ethno-religious minorities. This is what makes Iran, according to Michael Axworthy, an "Empire of the Mind," 44 an empire that effortlessly binds together an ethnically and linguistically diverse nation.

\section{Saudi Arabia's Raison D'etre: A Challenge to the Authority of the House of Saud}

The idea of the Saudi state is extremely weak and fragile. Saudi Arabia is often presented as the result of the 1744 pact between a Najd ${ }^{45}$ oasis ruler, Muhammad Ibn Saud $^{46}$ and a Muslim revivalist, Muhammad Ibn Abd Al-Wahhab, ${ }^{47}$ but the fact of the matter is that the creation of Saudi Arabia is a far more recent phenomenon. Although, the 1744 pact was the normative basis for the Al-Saud's legitimacy to ascend to the throne almost after two centuries of failed attempts to create a polity, one has to acknowledge that there are more nuances to the emergence of a centralized government in Central Arabia for the first time in history.

In most scholarship on Saudi Arabia, the onerous event of Al Saud's rise to rule over Arabia with its extremely inhospitable environmental features and highly segmentary society in terms of political identity is often times neglected or reduced to the

${ }^{44}$ Michael Axworthy, A History Of Iran: Empire Of The Mind (Basic Books, 2010) 294.

Najd is the geographical central region of Saudi Arabia. Riyadh (the country's capital) is located in this region.

${ }^{46}$ Muhammad Ibn Saud (1710-1765) was the amir of Diriya and is considered the founder of the First Saudi State and the Saud dynasty

${ }^{47}$ Muhammad Ibn Abd Al-Wahhab (1703- 1792) was trained from an early age in Islamic texts, and later he received further instructions in Hijaz, Basra and Al-Ahsa. Through his travels, Abd Al-Wahhab got struck by the distortions Islam had undergone and the decadence of people's faith. He decided to revive the true essence of Islam, according to his own reading, by returning to the original principles of Islam, purified from innovations. 
military might that Al-Saud enjoyed in the beginning of the $20^{\text {th }}$ century. As a matter of fact, the success of Abdul-Aziz ${ }^{48}$ in establishing a central authority in Arabia was due to his political genius in understanding tribal networks, the political power of Islam, and the impact foreign powers could have on the course of local politics. ${ }^{49} \mathrm{~A}$ brief overview of the course of historical events that led to the formation of Saudi Arabia in 1932 illuminates why the idea of Saudi state is highly fragile.

Before the emergence of contemporary boundaries in the Arabian Peninsula, this terrain was divided into four distinct regions of Hijaz, Asir, Ahsa, and Najd. These regions were also referred to as Western Arabia, Southern Arabia, Eastern Arabia, and Central Arabia respectively. Among these regions, Najd, currently hosting the country's capital Riyadh, was home to the initial developments that led to the establishment of Saudi Arabia in 1932.

Central Arabia was a highly diverse social context with such fluidity in the boundaries of identity and loyalty that prevented the establishment of any central authority beyond the parochial traditional intra-tribal and inter-tribal hierarchies. Despite this fluidity, Abdul-Aziz's understanding of tribal networks and dynamics enabled him to effectively use the message of Islam in order to establish his authority across tribal lines. In a context in which the survival of individuals and groups relied heavily on the careful replication of centuries-old practices of their ancestors, Abdul-Aziz established Al-Saud authority in Central Arabia through such novelties in approach that were unique in the history of Arabia. Within such a forbidding context, Abdul-Aziz used a religious

\footnotetext{
48 Abdul-Aziz (1875-1953), usually known in the West as Ibn Saud, was the founder and first monarch of Saudi Arabia.

${ }^{49}$ Christine M. Helms, the Cohesion of Saudi Arabia (Routledge, 2015) 70.
} 
narrative to cut across tribal assabiyah, ${ }^{50}$ in a land where no sheikh or $a m i r^{51}$ had ever claimed authority on the basis of religion; he revamped the traditional patterns of authority within and between tribes by eliminating the traditional elements that would put in place and maintain the authority of tribal sheikhs, and the authority of one tribe over another; he boastfully claimed the noble pedigree of Al-Saud as a basis of his rule, ${ }^{52}$ which was an uncommon practice among amirs in Najd who intentionally sought neutrality from tribal rivalries for effective ruling; and he unapologetically established the hereditary rule of his sons in spite of oppositions both within Najd and the Al-Saud family. ${ }^{53}$

The religious narrative upon which Abdul-Aziz justified his authority in Najd, was Wahhabism. ${ }^{54}$ Abdul-Aziz capitalized on the popular Wahhabi message in order to establish his rule in Arabia, where authority had for centuries been a function of continuously "shifting balances." ${ }^{\circ 5}$ Having realized that only through religion could one

\footnotetext{
${ }^{50}$ Ibn Khaldun, the $14^{\text {th }}$ century historiographer, in his Muqaddimeh, popularized the term. Assabiyah, with a negative connotation, refers to excessive group solidarity and cohesion in the context of tribalism.

${ }^{51}$ In Central Arabia, the $b a d u$ (the plural form for bedouin which refers to nomadic pastoralists of the desert) chiefs were addressed by the title sheikh, but the urban leaders and badu sheikhs who had managed to gain control of the settled areas were known as amirs.

${ }^{52} \mathrm{Abd} \mathrm{Al}-\mathrm{Aziz}$, a political genius, in his bid for authority over the entire Najd in which there were quite a number of tribes of noble descent with strong military might, shrewdly claimed noble pedigree of Al-Saud by virtue of blood link to Anaza (The 'Anaza tribe is amongst the largest and oldest Arabian tribes. Its members can be traced back to Prophet Mohammed's companions and its descendants can be found across the Arabian Peninsula. The name of this tribe is associated with nobility) tribe and affirming his family's claim to hereditary leadership of an area they had managed to hold onto with only two major interruptions since early 1700s. Abd Al-Aziz emphasized the rights and obligation of a Saudi leadership over the traditional tribal and urban leaders because Al-Saud, Abd Al-Aziz claimed, represented a lawful Arab and Islamic government.

${ }^{53}$ See Helms, The Cohesion of Saudi Arabia.

${ }^{54}$ Wahhabism is an ultraconservative religious movement of Sunni Islam, named after the $18^{\text {th }}$ century preacher and scholar Muhammad Ibn Abd Al-Wahhab

${ }^{55}$ Helms, 29.
} 
overcome the difficulty of controlling a society as segmented as that of the Arabian Peninsula, Abdul-Aziz, in his quest for authority over tribal and urban leaders in Central Arabia, stressed that the Al-Saud would represent "a lawful Islamic government." This assertion resonated well with the people of the peninsula. The union of politics and religion went a long way for Abdul-Aziz as within two centuries — from 1744 to the beginning of the $20^{\text {th }}$ century - a majority of the Central Arabia's settled populations had identified with Wahhabism. Abdul-Aziz's recourse to the power of religion was of course propped up by the alliance of the families of Al-Saud and Al-Wahhab, dating back to the 1744 meeting of Muhammad Ibn Saud and Muhammad Ibn Abd Al-Wahhab, when the latter found protection in Diriya,${ }^{56}$ ruled at the time by Muhammad Ibn Saud. Benefiting from the two-centuries-old alliance with the Al-Wahhab family, Abdul-Aziz invoked the message of the Wahhabi religious movement, presented his rule as a divine representation of God's Divine law. It was this message that permitted him (and later Saudi rulers) to transcend parochial tribal and urban loyalties. The discourse on which Abdul-Aziz was claiming political authority was unprecedented as the authority to rule in Central Arabia had remained secular all along for centuries.

Due to ecological exigencies of Central Arabia, the social, economic and political activities within Najd were essentially structured by its patriarchal tribal system, and the nature of authority held by the tribal sheikhs. For centuries, the tribe acted, and still does in many capacities, as the medium and guarantor of one's survival in the desert life. This function of tribal life create such a strong spirit of bounded tribal solidarity that would preclude individuals from an identification with other sources of identity. Ibn Khaldun

\footnotetext{
${ }^{56}$ Diriya is a town located on the north-western outskirts of Saudi capital, Riyadh. This town was the original home of the Saudi royal family.
} 
referred to such tribal sentiment as Assabiyah..$^{57}$ This is not a recent $20^{\text {th }}$-century phenomenon, rather it has been woven into the fabric of desert life for centuries. AbdulAziz's claim to Islamic leadership required that he abolish some aspects of traditional tribal customary law in order to weaken the position of the tribal sheikhs. In a fascinating maneuver in this pursuit, Abdul-Aziz revoked $k h u w a^{58}$ and replaced it with zakat, a compulsory "religious tax" that could only be collected by the Islamic leader. Beyond being a source of revenue for the burgeoning Kingdom, zakat played a more important normative role in reinforcing the legitimacy of Abdul-Aziz's rule on Islamic grounds. Abdul-Aziz was successful with his initiative of changing the status of the tribes and their traditional patterns of authority and eventually turning them into his loyal fighting force. Eventually, Abdul-Aziz managed to establish a hereditary rule of his sons by having the tribal leaders pledge allegiance to his nominee, ${ }^{59}$ an initiative that received the British support as well.

By 1912, Abdul-Aziz had restored the power of his ancestors and brought Najd under Al-Saud's control. With the beginning of the First World War in 1914, the British began intervening into Western and Central Arabia, the fringes of the Ottoman Empire. The British, through treaties, imposed protectorates on Najd and its rival Hijaz ruled by the Hashemites. However, the British gradually leaned towards Al-Saud as their potentially main reliable ally in Arabia, and as a result supported Al-Saud's successful

\footnotetext{
${ }^{57}$ Ibn Khaldun, The Muqaddimah : an introduction to history, 3 vols. (Princeton University Press, 1969).

${ }^{58}$ Khuwa was the tax levied by a stronger tribe on a client tribe in exchange for military protection

${ }^{59}$ Harold Richard Patrick Dickson, the Arab of the Desert. A Glimpse into Badawin Life in Kuwait and Sau'di Arabia (Routledge, 2015) 117.
} 
bid over Al-Rasheed amirate in $1921,{ }^{60}$ the most formidable enemy of the Al-Saud in Najd. This move was the precursor to the British eventual support of Abdul-Aziz's procession to Mecca and Jeddah to end the rule of the Hashemite dynasty in Hijaz. ${ }^{61} \mathrm{By}$ the Treaty of Jeddah in 1927, the British recognized the independence of Abd Al-Aziz's rule as the Kingdom of Hijaz and Najd.

The conquest of Hijaz and later expansion of Saudi rule over Arabia was indebted to the Ikhwan's daunting warfare skills. ${ }^{62}$ Their militarist prowess, their mobility and stamina in spite of the constraining features of desert life, and their religious zeal had made Ikhwan such a formidable force, loyal to Abd Al-Aziz, that was feared all over Arabia. Ikhwan emerged from the traditionally nomadic $b a d u^{63}$ who had embraced the Wahhabi dawa. After Abdul-Aziz successfully brought the badu under his rule by settling them in "agriculturally oriented colonies called hijra,"

\footnotetext{
${ }^{60} \mathrm{Al}$ Rasheed, or the House of Rasheed were a historic Arabian House or dynasty that existed in the Arabian Peninsula between 1836 and 1921. They were the rulers of the Emirate of Jabal Shammar and were centered in Ha'il, a city in northern Nejd that derived its wealth from being on the route of the Hajj pilgrimage and was a city known for its trading, which absorbed many of the travelers that were bound to Mecca.

${ }^{61}$ The House of Hashim, or the Hashemites were the royal family of the Hejaz (1916-1925). The family also ruled Iraq (1921-1958), and still rules over Jordan (1921-present). The dynasty was founded by Sharif Hussein ibn Ali, who was appointed as Sharif and Amir of Mecca by Sultan Abdul Hamid II in 1908, then in 1916 was proclaimed King of the Arab Lands (but only recognized as King of the Hejaz) after initiating the Arab Revolt against the Ottoman Empire. The Hashemites claim to trace their ancestry from Hashim ibn 'Abd Manaf (died c. 497 AD), the great-grandfather of the Islamic prophet Muhammad.

${ }^{62}$ The Ikhwan were the bedouins who underwent a huge transformation in their economic and social lifestyle in response to Abd Al-Wahhab teachings.

${ }^{63} \mathrm{Badu}$ is the plural form for bedouin which refers to nomadic pastoralists of the desert.

${ }^{64}$ Hijra, literally, means emigration or departure, but in Wahhabi religious texts it means a departure from a sinful past to submit to Islam and God's divine law in all aspects of life. Those oases that the badu settled in were called hijra because they symbolized the badu's abandonment of nomadic life in favor of membership in the Islamic brotherhood.
} 
Islamic message of equality of all men, recognized Abdul-Aziz as the Imam of a lawful Islamic Imamate, branded themselves the Ikhwan, meaning "the brethren," and formed a self-appointed Wahhabi religious militia that ultimately played an important role in helping Abdul-Aziz establish himself as the ruler of the Kingdom of Saudi Arabia.

The Ikhwan, who had themselves received the basic tenets of Wahhabism through mutawwiun, ${ }^{65}$ sent out to them by Abdul-Aziz, took the Wahhabi message to another level and ultimately became so radical in their practice and dawa that, after a while, they became critical of Abdul-Aziz for religious laxity. The Ikhwan later rebelled against the Al-Saud's rule and its policies in 1929. The rebellion, under the leadership of Sultan bin Bajad Al-Otaibi and Faisal al-Duwaish, was triggered when Abd Al-Aziz curbed the expansionist zeal of the Ikhwan into the British protectorates of Transjordan, Iraq and Kuwait. Ikhwan's leaders charged Abd Al-Aziz for "dealings with infidels." ${ }^{\circ 6}$ Ultimately, the Ikhwan's rebellion was defeated in the Battle of Sibila, where Saudi forces, with the help of the British, crushed the Ikhwan mercilessly in $1930 .{ }^{67}$ This victory paved the way for Abd Al-Aziz to continue Saudi conquest of the peninsula. In 1932, the two kingdoms of the Hejaz and Najd were united as the Kingdom of Saudi Arabia.

One of the key factors in Abdul-Aziz's success was his understanding of the role that foreign powers could play in support or against his bid for authority over Arabia. Abdul Aziz's rapport with Britain secured his authority, credibility and power. Britain's role in the establishment of the Kingdom of Hijaz and Najd in 1925, and later the

\footnotetext{
${ }^{65}$ Muttawwiun, literally meaning those who obey or volunteer, were the most intolerant of all Wahhabis. They served as the only authorities in direct contact with hijras, assigned to teach the badu the basic tenets of Wahhabi doctrine. They were also responsible for the collection of Zakat.

${ }^{66}$ Joseph Kostiner, The making of Saudi Arabia, 1916-1936: From chieftaincy to monarchical state. (Oxford University press, 1993).

${ }^{67}$ Wilfred Thesiger, Arabian sands (Penguin, 2007).
} 
unification of the two in 1932 is undeniable. Also, Britain helped Abdul-Aziz consolidate his power by assisting him with the recalcitrant Ikhwan, stubborn Hijazi inhabitants, the financial difficulties of the kingdom, and international recognition of his state. Of course, one cannot discount how a rapport with Saudi Arabia was beneficial also to Britain, as a strong ruler in Hijaz and Najd could bring peace to Central Arabia and stability to the regions bordering the British protectorates.

This brief historical account on the formation of the modern Saudi state demonstrates has interesting insights on the strength of the idea of Saudi state. The most difficult challenge that Saudi Arabia faces within its own polity is the weakness of the idea of Saudi state. The concept of nation in Saudi Arabia is highly underdeveloped to the extent that the real meaning of being a "Saudi national" is subject to public debate. The weakness in the idea of the state in Saudi Arabia could be accounted for form three dimensions: temporal, ideational, and structural.

From the temporal point of view, the fact that Saudi Arabia as a modern state, as opposed to centuries-long history of Arabia, has been around for slightly more than eighty years, explains why the idea of the state might still struggles to bring about loyalty to the central authority within the territory of the state. Identification with the higher sources of identity by individuals and groups does not happen instantaneously, rather it takes a long time for groups forming a community to go through identical historical experiences that would bind them through the creation of the same actual or mythical narratives. These narratives get passed on to next generations who would help, on their part, strengthen the national imagining. The emergence of Saudi Arabia as a state, 
compared to other Arab states of the region, was quite glorified. ${ }^{68}$ Although one may think that such narrative would spur valorization of one's state, in fact, perhaps only in Najd, the events leading up to the 1932 independence are reminisced, as these events were humiliating and painful for those who lost their autonomy to an outsider in Arabia. The other milestones in Saudi Arabia's relatively short history are of the same exclusionary essence, and not contributing to the strength of nationalistic sentiments. The Saudi establishment, through various top-down nationalist projects such as the annual Jenadriyah festival, ${ }^{69}$ attempts to enforce submission to the idea of the state through fostering a sense of national belonging among Saudi nationals; however, it seems that the kingdom is years away from experiencing the national awareness and solidarity enjoyed by older states.

On the ideational grounds, one has to look at the "organizing ideology"70 of the Saudi state which happens to be the state's raison d'etre. Once the idea of the state (its raison d'etre) is not self-referential and relies on an imposed ideology, this can turn into a host of threats to the survival of the state. Al-Saud's rule over the peninsula, began and was sustained over the years solely based on its heavy reliance on the message of Islam, particularly according to Wahhabi teachings. Wahhabi ideology grants legitimacy to Saudi political authority in so far as it conforms to the Divine Law and seeks to protect the Islamic $u m m a^{71}$ from disruptive forces and civil disturbance. The exclusionary nature

\footnotetext{
${ }^{68}$ Al-Saud expanded its rule over Arabia through a series of territorial conquests, and an anti-Ottoman, and later anti-British narrative. In other words, Saudi Arabia was not an arbitrary creation by the colonial powers.

${ }^{69}$ Al-Jenadriyah is a cultural and heritage festival held in Jenadriyah near Riyadh in Saudi Arabia each year since 1985, lasting for two weeks. It is organized by the National Guard.

${ }^{70}$ Buzan, People, State and Fear, 79.

71 This term is usually used to refer to the collective community of Islamic peoples.
} 
of such strict reading of Islam alienates non-Wahhabi Muslims, and even those Wahhabis whose adherence to Wahhabism is not considered "up to par." The issue with Shiites, constituting 10 to 15 percent of the population, is straightforward. Shiites have hardly ever been accepted in the Wahhabi dominated society and they have been subject to systematic discrimination. Not only are Shiites doubted by the Wahhabis to be truly Muslim, but they are often times lumped with Iranians and referred to as Majus which is a pejorative term for Persians.

The case with non-Wahhabi Sunnis is trickier. It might be argued that some moderation in the Saudi's organizing ideology can help make it less exclusionary so to include more non-Wahhabi Sunnis from other schools of jurisprudence; however, this is not a simple maneuver. Al-Saud family has learned from the turbulent years of the 1920s and 1930s that any retreat from their position could be highly detrimental to their rule. Ikhwan's challenge to the Saudi rule in the late 1920s, the seizure of the Mecca Grand Mosque by Juhayman Al-Oteibi ${ }^{72}$ in 1979, the political activities of Safar Al-Hawali ${ }^{73}$ as a part of Al-Sahwa Al-Islamiyah movement ${ }^{74}$ and Al-Qaeda's accusation of the Saudi ruling family are among the examples that can be seen from this prism. In other words, Saudi rulers always face the highly destabilizing threat that the idea of the state,

\footnotetext{
72 Juhayman ibn Muhammad ibn Sayf al-Otaybi (1936-1980) was a religious activist and militant who protested against the Saudi monarchy because, he believed, the House of Saud had lost its legitimacy through corruption and imitation of the West.

${ }^{73}$ Safar al-Hawali was one of the leaders of The Committee for the Defense of Legitimate Rights (CDLR) that was a Saudi dissident group created in 1993 and was the first ever opposition organization in the Kingdom openly challenging the monarchy, accusing the government and senior ulama (religious leaders) of not doing enough to protect the legitimate Islamic rights of the Muslims.

${ }^{74}$ Sahwa movement is a call for a greater role for clergy in governing, curbs on the royal family's privileges, greater transparency for public funds, and a more Islamically conservative society as a defense against Western cultural influences.
} 
regardless of its deficiencies, could be appropriated by a group claiming to profess the idea better than the state does.

There are some structural hindrances that prevent the full anchorage of the idea of the Saudi state. The existence of strong social forces such as regional, and tribal/familial ties which have never fully and willingly succumbed to the Saudi idea of social and political order is a direct challenge to the state's sovereignty within its territory. These are strong sources of identity that have to be reckoned with. When Saudis refer to the region they are from or their tribal affiliation, they make a fully-loaded statement of their class and social standing. Looking at the Hijaz region, the other regional pole of the Saudi state other than Najd, reveals how the "population has never fully accommodated to Saudi and Wahhabi rule." ${ }^{75}$ The cosmopolitan people of Hijaz look to the Red Sea, Egypt, and Syria for cultural sustenance, not to the desert of Najd with its strict Wahhabi ideology. In Asir, on the border with Yemen, Wahhabism is accepted only sporadically and reluctantly and the region has maintained its distinct traditions. ${ }^{76}$ In most regions other than Najd, the Saudi rule is perceived as an imposed concoction of Najdi rule with a distinctly myopic reading of the religion. ${ }^{77}$

On another important front, the idea of Saudi state is at constant competition with tribes which are traditionally reliable sources of identity in Arabia, and often than not, have delivered their promises. The natural impositions of Arabia's geography, for centuries, forced the inhabitants of the region to structure their social life in a way that

\footnotetext{
${ }^{75}$ Bruce Riedel, "Brezhnev in the Hejaz." The National Interest 115 (2011): 27-32.

${ }^{76}$ Mai Yamani, Cradle of Islam: The Hijaz and the quest for an Arabian identity (I.B. Taurus, 2009).

${ }^{77}$ See Madawi Al-Rasheed, ed. Transnational connections and the Arab gulf. Routledge Research in Transnationalism (London, Routledge, 2004).
} 
was not hospitable to the formation of any central authority. In an environment where man had to be on a constant move for his survival, and where tribal structures and traditional customary values would preclude the formation of allegiance to any other source of authority, the natural course of events would likely not have culminated in the emergence of any state, in a bottom-up process as it did, for example, in Japan. The tribal sentiments characterized by assabiyah, even in its diluted form, "corrode the foundation of urban citizenship" ${ }^{, 78}$ by resisting the eradication of traditional solidarities and intermediary linkages in favor of identification with and loyalty to the abstract of the state, which seems to require, more than anything, in Arab societies, a leap of faith. The establishment of Saudi Arabia is indebted to the brilliance and talent of a political entrepreneur, Abdul-Aziz. Abdul-Aziz realized the imperative of the top-down process of forming a "state-nation,"79 in which the state fosters an encompassing identity with which individuals and groups can identify beyond other allegiances. Abdul-Aziz used the powerful message of Islam to construct a new reality for $\operatorname{arab}$ and $h a d a r^{80}$ of mixed tribal populations, a reality that would supersede customary tribal bonds, laws and values. As the result of his initiatives, Saudi Arabia was brought into existence, nevertheless, unaccompanied by a strong idea of Saudi state.

The idea of the Saudi state is weak which requires that the Saudi leaders continually work to procure and maintain the loyalty of Saudi citizens, the fact that

\footnotetext{
${ }^{78}$ Bryan S. Turner, "A sociology of citizenship and human rights." in Rhiannon Morgan and Bryan S. Turner, eds. Interpreting Human Rights (London: Routledge, 2009) 177.

${ }^{79}$ Buzan, People, States and Fear, 76.

${ }^{80}$ The inhabitants of Central Arabia, regardless of their tribal origin, fell into two categories of Arab and hadar. The former groups lived in movable tents, but the latter were permanently settled.
} 
connotes a lack of "cultural sensitivity of sovereignty" ${ }^{\prime 81}$ among Saudi nationals. This is a point of concern for Saudi officials and a host of serious national security challenges. As Juergensmeyer aptly puts, "attachment to the spirit of social order" is inseparable from submitting to an "ordering agent." 82 Juergensmeyer argues that the degree of submission to the social order and the ordering agent correlates with political stability.

Saudis' traditional way of tackling challenges to the political stability has been one of coopting tribes and receiving their loyalty to the king. The rapid modernization of the oil era enabled the Saudi regime to pursue this policy quite effectively as it could incorporate tribes into the political system and rent distribution networks through informal patron-client linkages. To be fair, over the years, this policy helped strengthen Saudi national identity, but not on a solid and sustainable basis. Saudi nationalistic sentiments are, for the most part, a fragile function of the state's ability to handle economic crises, and provide employment, basic services and other public goods. There is no primordial, nor self-referential attachment to the Saudi state that would be on a par with the appeal and attraction of other social, centrifugal forces. In other words, the attachment does not go beyond the contractual level of interaction between the state and society.

This ties to the ideational dimension of the state the economy of Saudi Arabia which, understandably, tends to be highly politicized. The politicization of the economic sector in Saudi Arabia arises from the fact that the performance of economy, or lack

\footnotetext{
${ }^{81}$ Anthony Giddens, The Nation-State And Violence (University of California Press, 1985) 219.

${ }^{82}$ Mark Juergensmeyer, "Rethinking the Secular and Religious aspects of Violence," in Craig Calhoun, Mark Juergensmeyer, and Jonathan Van Antwerpen. Rethinking secularism (Oxford University Press, 2011). 195.
} 
thereof, has serious security ramifications. In the absence of an organic submission to the idea of the state, the ability of the central government to provide Saudi nationals with real jobs, and adequate income remain to be a critical measure of national security. One might think that Saudi Arabia, the oil rich country, should have no problem paying for the loyalty of its nationals. This is not true. Saudis face some serious conundrums in economic sector. Saudi Arabia's high dependence on oil revenues bears serious political and economic ramifications. Typical authoritarian character of most rentier states which tend to be the benefactor of society, an economy that dissuades innovation in the private sector, high level of unemployment and serious socioeconomic inequalities are among the most notable of these ramifications.

\section{Assessment}

The challenges and opportunities provided by the Iranian/Saudi idea of the state are inordinately in favor of the Iranian side. It appears that Saudi Arabia does not have much leverage over Iran's political processes and the challenges to the ruling elite as the result of these processes. For most of the period investigated in this research, Iran's political processes have been engineered and/or controlled, accommodating various political discourses, unless they surpass certain lines. Most Iranian political trends during the past century have operated within the legally defined boundaries of political activity — in spite of all deficiencies — and pushed the boundaries only slightly and sporadically. A glimpse over the records of political activities in Iran demonstrates that none of major political trends, Islamic, moderate, reformist, liberal, and leftist sought 
directions from the Arabs in the region, nor they had anything in common with the Saudis' political discourse.

On the other hand, Iran does not seem to have much leverage on the political processes in Saudi Arabia. The royal family politics in Saudi Arabia is more in tune with the power politics in other royal families in the region. John Duke Anthony documents interesting political interaction between Saudi Arabia and other conservative Arab states in the region on dynastic rivalries. ${ }^{83}$ Also, by assigning reliable family members to senior national security related cabinet posts, the Saudi royal family has maintained — with few exceptions - its control over the national and bureaucratic politics. Except from the Shiite opposition that may have been receptive to Tehran's directives after the 1979 revolution, almost no brand of oppositionists to the royal family, either secular or religious, looks up to Iran for directions. The discourse of the Sunni religious opposition has rarely, if ever, had any commonality with the Iranian anti-Saudi discourse. Yet, from within, it is apparent that Saudi Arabia is "formed out of force main and religious convictions in a forbidding land, ordered by divine law and a highly developed sense of shame, and governed by hereditary rulers strongly attached to a single of its regions." Therefore, the condition in Saudi Arabia remains "ripe for change." 84 This condition encourages certain approaches and policies by the Saudis that brings about conflict of interest, rivalry, tension and possibility of conflict between the two states.

\footnotetext{
${ }^{83}$ John Duke Anthony, "Aspects of Saudi Arabia's Relations with Other Gulf States," in Timothy Niblock, State, Society and Economy in Saudi Arabia (Routledge, 2015)

${ }^{84}$ James Buchan, "Secular and Religious Opposition in Saudi Arabia," in Timothy Niblock, State, Society and Economy in Saudi Arabia (Routledge, 2015) 106.
} 


\section{CHAPTER III}

\section{IRAN-SAUDI ARABIA (1924-1929): EARLY ENCOUNTERS AND THE RISE OF MUTUAL SUSPICION}

\section{Khūzestān Rebellion}

The very first encounter between Iran and Saudi Arabia occurred as early as the mid-1920s, almost a decade before the official establishment of the Kingdom of Saudi Arabia in 1932. This encounter was stirred by the suppression of Sheikh Khazal's rebellion in Khūzestān. ${ }^{85}$ This encounter came on the heels of the first direct confrontation between the Soviet Union and Western powers. The site of this confrontation was Iran, a country whose strategic location had rendered it the object of British and Russian rivalry as early as the end of the nineteenth century. ${ }^{86}$ Before delving into the developments leading up to Reza Shah's move to put an end to Sheikh Khazal's revolt, a brief historiography of Khūzestān, the center stage of this encounter, is warranted.

\section{A Brief History of Khūzestān and Arab Settlements in this Region}

It was in the early Islamic times that Arab geographers used the name Khūzestān to refer to the land inhabited by the Khūzīs, who are believed to be ancient Elamites'

\footnotetext{
${ }^{85}$ Khūzestān is an Iranian province located in the southwest of the country, bordering Iraq and the Persian Gulf. Khūzestān is deemed to have the oldest history, and referred to as the "birthplace of the nation." Historians believe that Khūzestān is by and large equivalent to ancient Elam where the Elamites inhabited.

${ }^{86}$ William R. Keylor, The Twentieth-Century World (Oxford: Oxford University Press, 1992) 255.
} 
descendance ${ }^{87}$ Elamites had preceded both Arabs and Persians ${ }^{88}$ and were related to neither. ${ }^{89}$ This community also gave its name to the region's capital, Suq al-Akhwaz. (market of the Khūzīs), which later became al-Ahwaz/Ahvaz. Before the Islamic conquest, the Achaemenids and Sassanids ruled over Khūzestān uninterruptedly, yet one needs to bear in mind that the history of Khūzestān in this period reveals extensive Persian-Arab interactions, as well as Arab tribal residence well before the Muslim conquest in the seventh century. ${ }^{90}$ With the Arab conquest, the Arab population in conquered areas rose significantly, before another round of Arab settlement in Khūzestān in the tenth century. ${ }^{91}$ Due to the geopolitical necessity of buffering against the Sunni Ottomans, the Safavids invited Shiite Arab tribes from Central Arabia to settle in Khūzestān.

The arrival of Shiite Najdi tribes at the invitation of the Safavids rendered the demographic mode of southern Khūzestān Arab. ${ }^{92}$ This massive Arabization explains why the western part of Khūzestān, and later in the eighteenth century the entire province came

\footnotetext{
${ }^{87}$ Vahid Rashidvash \& Mahmoud Jafari, "Iranian People and the Race of People Settled in the Iranian Plateau" JHSS, 17 (2012) 24.

${ }^{88}$ The ancient Elamite civilization stretches back as far as 3200 B.C. They were defeated by Assyrians in 640 B.C.

${ }^{89}$ Vasilli V. Barthold, An Historical Geography of Iran, trans. Svat Soucek (Princeton, NJ: Princeton University Press, 1984) 183-85.

${ }^{90}$ Among the Arab tribes residing in Khūzestān, Wa'el and Tamim are notable. See, Gharayaq-Zandi, D. Ir $^{-}$aniy' ${ }^{-}$an-e 'arab-tab ${ }^{-}$ar: mardom-shen ${ }^{-}$asi-ye $\mathrm{s}^{-}$akht $^{-}$ar-e qowmi-ye a' $\mathrm{r}{ }^{-}$ab-e khuzest ${ }^{-}$an [Iranians of Arab Origins: An Anthropology of the Ethnic Structure Among Khuzestan's Arabs], (Tehran: Nashr-e Afkar, 2008) 75.

${ }^{91}$ Rasmus C. Elling, Minorities in Iran: Nationalism and Ethnicity after Khomeini (Palgrave Macmillan, 2013) 37.

${ }^{92}$ See Amir Hossein Khonji, "Sabegheye tarikhi e eskan e ashayer e Arab dar khuzestan," [The History of Accommodation of Arab Tribes in Iran]. Persian Gulf Studies, Retrieved from http://www.persiangulfstudies.com/userfiles/files/Arabs-in-Persiangulf.pdf accessed on 1/27/2017.
} 
to be referred to as Arabistan. ${ }^{93}$ "Even though medieval Iranian rulers often left the Arab sheikhs of Khūzestān to their own devices,"94 the name Arabistan never implied the formation of any autonomous political entity, independent from Persian central government. This is not to contend the geographic and demographic proximity of Khūzestān to Mesopotamia, but politically, this province has been connected to the adjacent Iranian plateau for millennia, under both Persian and non- Persian dynasties. ${ }^{95}$

\section{Sheikh Khazal at the Clutch of the British Interests in the Great Game}

Under Qajar rule, Arabistan had a hereditary local ruler, who was subordinate to Tehran. However, by 1923, Khūzestān was effectively outside Tehran's weakened control. The province at the time was ruled by an ambitious local Arab leader, Sheikh Khazal who enjoyed the British protection delivered by the British army operating in southern Iran. ${ }^{96}$ Since Sheikh Khazal's defiance toward Tehran and his bid for independence were reinforced by the British promise of support against the central government, therefore, the support and protection that the United Kingdom offered Sheikh Khazal needs to be contextualized. This protection is best explicated by the long-standing, yet growing in complexity, British interests in the Persian Gulf in early years of the $20^{\text {th }}$ century.

\footnotetext{
${ }^{93}$ Barthold, An Historical Geography.

${ }^{94}$ Elling, Minorities in Iran, 37.

${ }^{95}$ Barthold, an Historical Geography.

${ }^{96}$ See Yadullah Shahibzadeh, the Iranian Political Language: From the Late Nineteenth Century to the Present. Springer, 2015); Kaveh Farrokh, Iran at War: 1500-1988 (Osprey Publishing, 2011)
} 
In the decades prior the First World War, Iran had turned into a stage for BritishRussian rivalry, with the two parties having Iran effectively partitioned into their spheres of influence. The discovery of massive amounts of oil in Iran elevated the British stakes in the Great Game. The advent of oil and the exclusive oil rights granted to a New Zealander, William Knox D'arcy, ${ }^{97}$ in 1901 for 60 years virtually turned Iran from a terrain solely serving as a buffer between the Tsarist Russian Empire and the British interests in the region to an important geopolitical and geo-economic asset.

According to Spykman and Rollins, a historically evidenced common behavior among states is their push toward the sea. ${ }^{98}$ Perhaps, Russia represents the most striking case of such behavior. Historically, Russia has been persistently pursuing access to the open seas. After the founding of St. Petersburg by Peter the Great in 1703, Russia's avarice for real estate shoring on various bodies of water began. From 1703 through 1808, Russia's conquest of the lands from Sweden and Finland, in this pursuit, did not quite yet put Russia on the North Sea or the Atlantic Ocean. Within two centuries, Russia tried every direction and all means for access to the open seas, including fighting seven wars with the Ottomans in an attempt to reach the Mediterranean by way of Constantinople, aggressive policies towards Serbia aiming at securing an Adriatic port, establishing Nikolaievsk at the mouth of Amur in 1851 and Vladivostok in 1860; and leasing Liaotung and Port Arthur to reach to the Korean Peninsula. Russia's effort to access the open seas was opposed and rejected by major powers or a coalition of them at every turn. Consequently, at the opening years

\footnotetext{
${ }^{97}$ For documents regarding the concession, refer to Ali Farahmand, "Nagofteh haye emtiaz e d'arcy" [The Untold of the D'arcy Concession] Tarikhe Ravabete Khareji, no.29 (2006).

${ }^{98}$ Nicholas J. Spykman \& Abbie A. Rollins, “Geographic Objectives in Foreign Policy, II.” American Political Science Review, 33, 04 (1939) 591-614.
} 
of the twentieth century, Russia found itself with an unrealized dream of shoring a major warm water port. ${ }^{99}$ Particularly after its unsatisfactory bid to obtain predominance in the Balkan Peninsula and control of the Turkish Straits, Russia redirected its expansionist drive to a dormant quest for access to the warm waters of the Persian Gulf. Russia rightfully deemed bidding for the Persian Gulf as a more plausible strategy than going for the Mediterranean. Access to the Mediterranean was guarded by the Ottomans who, in the hindsight, were a couple of decades away from their demise. On the other hand, nominally independent Persia, blocking Russia's access to the Persian Gulf, was dramatically weakened during the Qajar rule, thus impotent to effectively hinder Russia's encroachments.

Russia's effort to increase influence and presence in Iran did not go unchecked because of Iran's significant role in the protection of the British interests in the region. Russian economic penetration of Persia in the early years of the twentieth century, which included the issuance of loans, plans to construct a railroad from the Russian frontier to the Persian Gulf, and the acquisition of favorable tariff treatment for Russian exports, had resulted in an acute rivalry with Great Britain. London viewed the prospect of Russian economic hegemony in Persia as a prelude to political predominance, a menace to the security of the British sea lanes to the Far East. The British also felt threatened by the same encroachments in Afghanistan, the traditional buffer between Russia and British India. As a consequence, Russian expansionism in southern Asia met with British opposition at every turn. ${ }^{100}$

99 ibid. 600.

${ }^{100}$ Keylor, The twentieth-century world, 11-12. 
The constitutional movement in Persia at the turn of the century gave Britain an edge over Russia. In December 1905, the constitutional movement began as a protest by a coalition of reformers of all walks of life who demanded the government to accede to their demands for a constitutional government. ${ }^{101}$ The constitutional movement was more inclined to receive support from Britain than Russia because it was a parliamentary democracy, unlike the authoritarian nature of the tsarist Russia. ${ }^{102}$ Mozaffar e Din Shah eventually succumbed to protesters' demands in August 1906 and issued a decree to allow for a constitutional assembly to convene. Mozaffar e Din Shah's death was a turning point in this balance. Upon the passing of Mozaffar e Din Shah, his pro-Russian son Mohammad Ali ascended to the throne in 1907. Mohammad Ali Shah was subservient to Russia's imperialism in Iran from the outset, the sign of which was his heavy reliance on the Russian-officered Persian Cossack Brigade. ${ }^{103}$

The weight of Russian influence, however, waned temporarily with the 1917 Bolshevik revolution and the collapse of Tsarist Empire. This meant that the British had the opportunity to organize and supervise the exploitation of the vast reserves of recently discovered petroleum while striving to establish predominant political influence on the government in Tehran. D'arcy, on behalf of the British government, approached the Anglo Iranian Oil Company (APOC) which had discovered oil ${ }^{104}$ in commercial quantities in

\footnotetext{
${ }^{101}$ William L. Cleveland \& Martin P. Bunton, A History of the Modern Middle East. ed. (Westview, 2012) 142.

102 Janet Afary, the Iranian Constitutional Revolution, 1906-1911: Grassroots Democracy. (Columbia University Press., 1996) 33.

${ }^{103}$ See Firuz Kazemzadeh, "Iranian relations with Russia and the Soviet Union," in The Cambridge History of Iran. Vol. 7: From Nadir Shah to the Islamic Republic (1992) 314-342.

${ }^{104}$ Rose Greaves "Iranian Relations with Great Britain and British India, 1798-1921," in The Cambridge History of Iran, 7 (1991) 412.
} 
Khūzestān in 1908, the first of such discovery in the Middle East, ${ }^{105}$ in order to pave the way for Britain's involvement in the Iranian oil business. Soon, the British government and APOC were engaged in business deals without consulting Tehran, turning Iran into the first and primary oil producer for the British Empire.

The significance of oil for Britain was first and foremost in its utility for the oilmilitary complex. New technology has always been cited as an impactful element on the assessment of "threats, vulnerabilities and the (in)stabilities of strategic relationships." 106 Such an impact is as much a function of non-military technology as it is a function of the military kind as the history of military and civilian technologies is one of interplay and "dual use."107 By 1912, the British Navy was converting the fuel systems of its vessels from coal to oil for more efficiency and potential outmaneuvering the German fleets. ${ }^{108}$ This was a transformational shift in the British strategic calculations. While the disadvantages of coal were reflected in Churchill's advocacy for the use of oil, ${ }^{109}$ it was difficult to justify transitioning the royal fleet from the use of coal to oil, considering Britain's massive strategic reservoir of coal and the scarcity of oil resources. Even Churchill had his own hesitations. He knew that "the advantages conferred by liquid fuel were inestimable" but he also recognized that to switch "the foundation of the navy from

\footnotetext{
${ }^{105}$ Roger Adelson, London and the Invention of the Middle East: Money, Power, and War, 1902-1922 (Yale University Press, 1995) 97.

${ }^{106}$ Barry Buzan \& Lene Hansen, The evolution of international security studies (Cambridge University Press, 2009) 53.

107 ibid. 53-54.

108 Adelson, London and the Invention, 97-98.

${ }^{109}$ Churchill believed that "the ordeal of coaling ship exhausted the whole ship's company. In wartime, it robbed them of their brief period of rest; it subjected everyone to extreme discomfort." Winston Churchill, The world crisis, 1911-1918 (Simon and Schuster, 2005) 134.
} 
British coal to foreign oil was a formidable decision in itself." ${ }^{110}$ Eventually, with the advisory of Admiral Fisher, ${ }^{111}$ the First Lord of the Sea from 1904 to 1910, who regularly offered Churchill advice on a variety of naval matters, ${ }^{112}$ and also the assessment of the war college ${ }^{113}$ Churchill started to believe that outmaneuvering the German fleet would only happen with his endorsement of the transition. This evolution redefined the significance of the Persian Gulf in strategic calculations of the Britain.

In face of the growing strategic significance of the region and encroachment of Russia and other rival European powers, Great Britain found it imperative to keep all the Arab rulers onboard to protect this important body of water from hostile approaches. Britain's comprehensive policy of tasking the local Arab rulers to defend British geopolitical and oil interests gradually prevailed the entire region. The Sultanate of Muscat and Oman overlooked the longest coastline in the Arabian coast of the Persian Gulf nearly 1000 miles stretching from the frontier of Hadhramaut Protectorate on the Arabian Sea, round the cape of Ras al-Hadd, and along the south coast of the Gulf of Oman to the Straits of Hormuz. During the 19th century, The Sultanate had concluded several treaties of friendship and commerce, reinforced by the 1908 Agreement of Friendship. ${ }^{114}$ On another front, by the Exclusive Agreement of March 1892, Britain had the seven Trucial Sheikhs,

\footnotetext{
110 ibid. 133-136.

${ }^{111}$ Admiral Fisher was known as an "oil maniac" as early as 1886. See John A. Fisher, Records by Admiral of the Fleet, Lord Fisher (Hodder and Stoughton, 1919) 202.

112 ibid, 402.

${ }^{113}$ Erik J. Dahl, Naval innovation: from coal to oil. (National Defense University, Washington DC Institute for National Strategic Studies, 2001) 52.

114 John C. Wilkinson, "The Oman question: The background to the political geography of Southeast Arabia," Geographical Journal, (1971) 361-371.
} 
shoring on 400 miles of coastline beyond the Strait of Hormuz, pledge not to enter into an agreement or correspondence with any government except the British Government, and not to receive foreign agents and make concessions. ${ }^{115}$ Therefore, there was not much of an effort needed on the part of Britain to socialize the Trucial Sheikhs into the arrangement. The Sheikhdom of Qatar entered an agreement containing similar stipulations with Great Britain in 1916. ${ }^{116}$ British relations with Bahrain were even closer as the ruling dynasty had been in treaty relations, first with the East India Company, and then with the British Government since 1820. Bahrain had considerable economic importance for Britain because of its pearl fisheries, its placement in the corridor of trade to Najd and Al-Ahsa, and then later because of oil discovery in 1932, and eventually its excellent airbase on the island of Muharraq on the Imperial Airways Route to India. The ruler of Bahrain had committed to Britain not to enter into relations with any other foreign power. Kuwait, on the bay of the Arabian coast near the head of the Persian Gulf and contiguous with Iraq was already formal British Protectorate. The Kuwaiti Sheikhdom included the island of Bubiyan which could serve as an important base in the defense of hostile approaches to the Shatt Al-Arab. In case of Iraq, Great Britain had special treaty relations with this country despite its very short coastline at the head of the Persian Gulf. Even beyond that, the important port of Basrah, just like all other ports in the Arabian coast of the Persian Gulf was "to some extent liable to British control."117

\footnotetext{
${ }^{115}$ Husain M. Albaharna, The legal Status of the Arabian Gulf States: a study of their treaty relations and their international problems. (Manchester University Press, 1968) 29-32.

116 ibid. 38.

${ }^{117}$ M.B. "British Interests in the Persian Gulf” Bulletin of International News vol. 18, No. 19 (1941) 1197.
} 
In the order that the British had designed for the Persian Gulf region, Iran could have played a significant role; however, Qajar kings had proved to be highly incompetent to enforce effective rule throughout an already shrinking country. During Qajar rule, Iran lost large swaths of its integral territories to Russia and it was not surprising that the British did not want to risk their interests in the region by handing over the protection of their assets to the inept central government in Tehran. Britain had no confidence in Qajars and the central government in Tehran for securing their oil and regional interests. ${ }^{118}$ As the result, Britain began forging ties with many of Iran's southern tribes, notably the chiefs of Bakhtiari tribes ${ }^{119}$ and Sheikh Khazal, the leader of Khūzestān's Arab-speaking population, ${ }^{120}$ with the hope that they would protect the APOC facilities. ${ }^{121}$

\section{Sheikh Khazal's Rise to Power and Quest for Autonomy}

Khūzestān had been semi-autonomous but subject to the Iranian crown for several centuries. Qajar shahs typically appointed a governor-general to manage the affairs of the province. Following the same pattern, the leadership of the Bani Kaab and the city of

\footnotetext{
${ }^{118}$ As noted by Adelson (1995), "Given the weakness of the government in Tehran, APOC [Anglo-Persian Oil Company] simply negotiated with Arab chiefs in Khūzestān and arranged for Bakhtiyari tribal leaders to guard the company facilities;" See also William Strunk, "Britain, Persia, and Shaykh Khaz'al: The genesis of a special relationship." in Roger Olson (ed.), Islamic and Middle Eastern Societies, (Brattleborough, VT, 1987), pp. 152- 71.

${ }^{119}$ See Ghaffar Pour Bakhtiar, "Khaneine bakhtiari, dolat e englis va siasathaye nafti," [Bakhtiari Tribes, Britain and Oil Policies] Tarikh e Ravabet e Khareji, no. 41, 2009.

${ }^{120}$ Pezhmann Dailami, "The populists of Rasht: Pan-Islamism and the role of the Central Powers," in Touraj Atabaki, Iran and the First World War: Battleground of the Great Powers, ed. (London: I. B. Tauris, 2006) p.148.

${ }^{121}$ Adelson, London and the Invention, 97.
} 
Muhammara $^{122}$ was assumed by Maz'al Khan in 1881 , whose position as a governorgeneral was confirmed by a royal edict from Tehran. In 1987, Maz'al Khan was killed by his brother Khazal in his quest to become the sheikh of Muhammara. ${ }^{123}$ While the Qajar's authority in Khūzestān was plummeting and it was not long before Tehran's control over the province was only nominal, the king approved Khazal's position as the new governorgeneral of Khūzestān and gave him the Neshan e Aqdas medallion in 1920. By 1921, Sheikh Khazal had achieved complete dominance over Khūzestān and rough independence from Tehran.

As mentioned above, Britain found utility in creating and maintaining a bond with the governor-general of Khūzestān. The first written assurance of support to Sheikh Khazal by the British goes back to 1902 which was repeated in 1907 by Sir Percy Cox. ${ }^{124}$ The most serious of such assurances came after the discovery of oil in massive quantities in Iran, which urged the British to sign a treaty with Sheikh Khazal in 1909-1910 assuring him of their support against any attack against his rule. ${ }^{125}$ This treaty honored Sheikh Khazal by giving him the title, "Knight Commander of the Indian Empire." ${ }^{126}$ In exchange, Sheikh Khazal vowed to protect British oil assets and ensure stability in the region. By 1919, the

\footnotetext{
${ }^{122}$ Muhammara is today's Khorramshahr, an Iranian town in the southwest.

${ }^{123}$ Henry James Whigham, the Persian Problem. (Isbister and Company Limited, 1903) xi.

${ }^{124}$ Major General Sir Percy Zachariah Cox (1964-1937) was a British Indian Army officer and Colonial Office administrator in the Middle East.

125 Steven R. Ward, Immortal: A Military History of Iran and Its Armed Forces, update ed. (Georgetown University Press, 2014) 138.

${ }^{126}$ Michael P. Zirinsky, "Imperial Power and Dictatorship: Britain and the Rise of Reza Shah, 1921-1926." International Journal of Middle East Studies, 24, 4 (1992) 563; Robert M. Burrell, and Robert L. Jarman, Iran: Political Diaries, 1881-1965, (Cambridge University Press, 1997) vii.
} 
British had equipped Khazal with 3000 rifles, ammunition and a steamer for the specific purpose of protecting British oil assets. ${ }^{127}$

There is evidence that Sheikh Khazal's bid for dominion over Khūzestān had more substance to it than the age-old problematique of center-periphery relations. In fact, Sheikh Khazal had claimed the mantle of Arab nationalism. He had consciously relinquished his identity and ethnicity from Arab-Iranian to Arab so that he could obtain Great Britain's attention and connect with the rulers of the Arabian coast of the Persian Gulf. ${ }^{128}$ For that matter, Persians consider the British treaty with Sheikh Khazal "as a national humiliation." 129 This historical low point in the collective memory of the Iranian explains why Sheikh Khazal has often been negatively portrayed in the contemporary Iranian history. ${ }^{130}$

Britain trusted Khazal as he increasingly demonstrated a cooperative attitude and unwavering commitment to securing the British interests in the region. This bond strengthened to the point that in 1909, Khazal negotiated the Cox-Khazal agreement on behalf of the Anglo-Persian oil company (APOC) without consulting Persia's central

\footnotetext{
${ }^{127}$ Stephanie Cronin, "Building a New Army: Military Reform in the Qajar Era." in Roxane Farmanfarmaian, War and Peace in Qajar Persia: Implications Past and Present (London: Routledge, 2008) 66-67; See also Zirinsky, "Imperial Power," 653-654.

${ }^{128}$ Sian Jones, the Archaeology of Ethnicity: Constructing Identities in the Past and Present, (Routledge, London. 1997) 82.

${ }^{129}$ Peter Hopkirk, On Secret Service east of Constantinople: The Plot to Bring down the British Empire. (Oxford University Press, 2001)106.

${ }^{130}$ Leila P. Yazdi, "What He Thought... What He Did: An Archaeological Study of the Persian Gulf Coasts Colonial Sites of Sheikh Khazal Khan in the Early Twentieth Century." International Journal of Historical Archaeology, 17, 1 (2013) 2; Sheikh Khazal is referred to as a hero by Pan-Arabists of Khūzestān, See Berch Berbeglou, Nationalism and Ethnic Conflict: Class, State and Nation in the Age of Globalization, (Rowman and Littlefield, Lanham, 2006).
} 
government. ${ }^{131}$ Sheikh Khazal had greater ambitions. According to Ferrier and Bamberg, the stature he was aspiring was becoming the mere trusted agent in the region assuming responsibility for the safety of the oil fields in all Arabia. ${ }^{132}$ Sheikh Khazal remained effectively outside Tehran's control as late as the early 1920s. ${ }^{133}$ Sheikh Khazal benefited the weakness of the central government, and established - with the British support and encouragement - an autonomous Sheikhdom in Khūzestān and brought oil bearing territories under British suzerainty and control. ${ }^{134}$

\section{The Rise of Reza Khan to Power}

Some other crucial developments were unfolding during these years in Iran. In January 1921, the commander of British forces in Iran, General Edmund Ironside chose to promote Reza Khan, who had been leading the Tabriz battalion, to lead the entire brigade. ${ }^{135}$ Within only a month, Reza Khan led his detachment of the Cossack Brigade to Tehran and seized the capital. He forced the dissolution of the previous government and demanded the appointment of Seyyed Zia'eddin Tabatabaee as Prime Minister. Britain assisted Reza Khan with the 1921 coup d'état, hoping that it would slow down and ideally halt the Bolsheviks' penetration in Iran. Britain received the rise of Reza Khan exuberantly

\footnotetext{
${ }^{131}$ Farmanfarmaian, War and Peace. 219.

${ }^{132}$ Ronald W. Ferrier \& Bamberg, J. H. The History of the British Petroleum Company (Cambridge University Press, Cambridge. 1982) 393.

${ }^{133}$ Ward, Immortal, 69-71.

${ }^{134}$ Mohammad G. Majd, Great Britain and Reza Shah: The Plunder of Iran, 1921-1941 (University Press of Florida, Gainesville, 2001) 242.

${ }^{135}$ Cyrus Ghani, Iran and the Rise of the Reza Shah: From Qajar Collapse to Pahlavi Power. (IB Tauris, 2000) 147.
} 
as this policy seemed to be providing what it had promised at its face value. In a situation report to the British War Office on Dec. $8^{\text {th }}, 1920$, General Ironside praised Reza Khan as a capable Persian officer in command of the Cossacks which "would solve many difficulties [for Britain] and enable [them] to depart in peace and honor."136

Reza Khan spent the rest of 1921 securing Iran's interior, responding to several revolts that erupted against the new government and suppressing the federal rulers of Qajarid Iran. ${ }^{137}$ In the same year, alerted by Reza Khan who had just staged a coup with Seyyed Zia'eddin Tabatabaee, ${ }^{138}$ Khazal proceeded to take steps to protect himself. Khazal attempted to form an alliance with all the Bakhtiari, Lur and Khamesh tribes, believing that such tribal alliance would become an impenetrable barrier in the Zagros Mountains against the forces of the central government. Khazal's tribal alliance proposal, nevertheless, remained mostly unanswered. Khazal then tuned to Ahmad Shah Qajar and the Imperial Court of Tehran, presenting himself as a loyal defender of the dynasty, calling upon the Court to take necessary actions against the ambitions of Reza Khan. This initiative was not successful either. Khazal's next recourse was to seek alliance with the opposition to Reza Khan in the parliament. In this pursuit, he wrote a letter to Ayatollah Modarres, presenting himself as a constitutionalist, a liberal democrat and a fierce Iranian nationalist. Although the opposition cautiously accepted his proposal but the parliamentary opposition to Reza

\footnotetext{
${ }^{136}$ Richard H. Ullman, The Anglo-Soviet Accord (Princeton University Press, 1972) 384; See also Ali M. Ansari, Modern Iran since 1921: The Pahlavis and After (Pearson Education, 2003) 26-31.

${ }^{137}$ Hossein Makki, The History of Twenty Years, Vol.2, Preparations for Change of Monarchy (Mohammad-Ali Elmi Press, 1945) 87-90, 358-451; See also Ghani, Iran and the Rise of the Reza Shah, 270-273.

138 Zia'eddin Tabatabaee (1888-1969) was an Iranian politician, Mayor of Tehran (1921-1923) and Prime Minister of Iran from February to May 1921 under Ahmad Shah, the last king of Qajar.
} 
Khan failed on its very own mission. ${ }^{139}$ In 1924 , Khazal decided to take his case to the League of Nations and gain international recognition for the secession of his sheikhdom from the Iranian territory, yet this attempt ended in failure as well.

In November 1924, Reza Khan sent 3000 soldiers to subdue the rebellious Sheikh. ${ }^{140}$ Khazal turned to the British for help; however, Britain did not honor Sheikh's request as they had already determined a new course of policy toward Iran and the region. After refusing to mediate between Sheikh Khazal and Reza Khan, ${ }^{141}$ Britain had to decide whether to continue supporting Sheikh Khazal's local autonomy or side with a strong central government that was forming up in the hands of Reza Shah. British policymakers embarked on debates over the utility and feasibility of such a policy shift. ${ }^{142}$ Sir Percy Loraine, the British minister in Tehran from 1921 through 1926, called London on May 5, 1923, urging a policy reexamination toward Iran. Loraine argued that "support[ing] Minister of War, [Reza Khan] ... might enable [Britain] to control [him] to some extent and perhaps tie him down to definite assurances. [This] support would also strengthen bulwark against Russia." He continued that opposing Reza Khan meant the "gradual collapse of our position and influence ... [which can play] into the hands of Russia." ${ }^{" 143}$ At first the Foreign Office opposed Loraine's guidance and argued for the support of the

\footnotetext{
${ }^{139}$ Richard W. Cottam, Nationalism in Iran (University of Pittsburgh Press, Pittsburgh, 1964) 113.

${ }^{140}$ Michael Zirinsky, "The rise of Reza Khan." in John Foran, A Century of Revolution: Social Movements in Iran, ed. (University of Minnesota Press, 1994) 44-77.

${ }^{141}$ Gordon Waterfield, Professional Diplomat, Sir Percy Loraine, (Murray, London, 1973) 68-70; See also Zirinsky, "Imperial Power and Dictatorship," 654.

${ }^{142}$ Waterfield, Professional Diplomat; Zirinsky, "Imperial Power and Dictatorship,” 564.

${ }^{143}$ Loraine, Tehran, 5 May, 1923, FO, 37119024 quoted in Zirinsky, "Imperial Power and Dictatorship," 564.
} 
Bakhtiaris and Sheikh Khazal even if it takes "dispatching a gunboat to Muhammarah."144 However, in an October memorandum prepared by military attaché Lieutenant-Colonel Sanders, Loraine explained to London that the tribes are no match for Reza Khan's growing power. ${ }^{145}$ Once the crisis began, the Foreign Office instructed Loraine to support Reza Khan even at the expense of the Sheikh's "disappearance from Arabistan."146 Eventually, Britain completely withdrew its support and protection of Khazal's rule, telling Sheikh that the only reason they had supported him to begin with was due to the central government's inability to properly enforce its rule in Khūzestān. ${ }^{147}$ Reza Khan's arrival to Bushehr and concentration of Iranian soldiers around Ahwaz were enough to convince Sheikh Khazal to seek a negotiated settlement. Sheikh Khazal then disbanded his Arab forces and retired to Mohammerah. Later in 1925, Reza Khan forcibly took him to Tehran, liquidated his assets in the Iranian territory, and put him under house arrest until his death in 1936. There are doubts whether his death was due to natural causes or he was murdered by one of the guards at the direction of the Shah. ${ }^{148}$ The latter is by no means an unlikely scenario. In his Inside Asia, John Gunther describes the climate of fear during Reza Shah's reign:

There is no trial, no sentence. Enemies are supposed to be removed, if removal for good is deemed necessary, not by the headman's ax or firing squad but by more melodramatic method of poisoning. The disgruntled call it cheerlessly the inoculation Pahlavi. A pellet in the breakfast coffee one

\footnotetext{
${ }^{144}$ Churchill, Foreign Office, 9 May 1923, FO 37119024.

${ }^{145}$ Lorraine, Tehran, 6 October 1923, FO 37119025 quoted in Zirinsky, "Imperial Power and Dictatorship," 654.

${ }^{146}$ FO 371, 34 (Persia) files, 1924; FO 1011 quoted in Waterfield, Professional Diplomat, 83-98.

${ }^{147}$ Ward, Immortal, 139; See also Masoud Kazemzadeh, "Tribal Politics in Iran: Rural Conflict and the New State, 1921-1941.” Middle Eastern Studies, 44.1 (2008) 153-157.

${ }^{148}$ For example, see Ervand Abrahamian, E. Iran between two revolutions (Princeton University Press, 1982) 150; Denis Wright, The English amongst the Persians: during the Qajar period 1787-1921 (I.B. Taurus, 2001) 72 .
} 
fine day — and then there aren't any more fine days. It may be announced that the victim died of a stroke. ${ }^{149}$

\section{How Abdul Aziz Perceived the Developments in Persia}

These developments in Iran did not go unnoticed by Abdul Aziz who at the time was unifying the Arabian Peninsula under his rule. There is no evidence of direct contact between Abdul Aziz and Sheikh Khazal at the time of the crisis; however, a close rapport among Sheikh Khazal and Abdul Aziz of Najd and Sheikh Jaber Al-Mubarak, the Amir of Kuwait has been documented. ${ }^{150}$ Al-Qassemi, the widely recognized Emirati commentator on Arab affairs, corroborates this assumption and argues that Sheikh Khazal, during his reign "was in constant contact with the tribal chiefs of Basra (both Sunni and Shia), Kuwait, and Saudi Arabia. In fact, he had called for an Arab alliance in the face of what he saw as a growing Persian threat." ${ }^{151}$ Although Al-Qassemi does not directly refer to the ruler of Najd, but it is strongly likely that Sheikh Khazal, considering his political opportunism, was in tune with the developments in Central Arabia from 1912 onward. An edited document on the career and legacy of Abdul Aziz contains a picture of him with some of his entourage in Basra with Sheikh Khazal standing on his immediate right-hand side. ${ }^{152}$ Therefore, it is not unimaginable that Abdul Aziz would have found the developments in

\footnotetext{
${ }^{149}$ See John Gunther, Inside Asia, (Harper, 1939) 499-516.

${ }^{150}$ Efraim Karsh \& Inari Karsh, Empires of the Sand: The Struggle for Mastery in the Middle East, 17891923, (Harvard University Press, Cambridge, 2009) 139-140; See also Menahim Mansoor, Political and Diplomatic History of the Arab World, 1900-1967: A Chronological Study (University of Michigan Press, Ann Arbor, 1972).

151 Sultan Al-Qassemi, S. "Tribalism in the Arabian Peninsula: It is a Family Affair,” Jadaliyya, February 1, 2012, retrieved from www. jadaliyya. com/pages/index/4198/tribalism-in.

${ }^{152}$ Retreived on 1/17/17 from http://bfg-globals.com/portal/monthly/english/issue/1-ensalman.pdf
} 
Khūzestān, and Reza Shah's ambitions in the region alarming, particularly with respect to Bahrain. The Persians had long claimed sovereignty over Shiite majority Bahrain, and it was not hard to assume the same fate for the rulers of Bahrain as that of Sheikh Khazal in Khūzestān.

\section{Treaty of Jeddah: Foiling Iran's Claim to Bahrain and the Resulting Increase in Mutual Skepticism}

Saudi Arabia's major international base of support was Britain. In fact, the link with Britain helped Abdul Aziz maintain his power and strengthen his regional position both during and after the First World War up to the Second World War. The initial pressure to initiate close relations was pursued by Abdul Aziz rather than the British. ${ }^{153}$ Abdul Aziz had reached out to British representatives in the region almost immediately after his conquest of Riyadh in 1902, hoping to consolidate his power by persuading the British to offer protection for his emirate against other local emirates.

At the turn of the century, the Ottomans who had overall suzerainty over the interior regions of the Arabian Peninsula, therefore, Britain was more invested in coasts of the Persian Gulf fearing that any meddling in the interior of the peninsula would jeopardize their relationship with the Ottomans. Even when Ikhwan forces took control of Al-Ahsa in 1913, thereby reaching the Persian Gulf coast, Britain refused to give Abdul Aziz any commitment. ${ }^{154}$ Britain's position, however, changed radically with the outbreak of the First World War, especially after 30 October 1914, when the Ottomans declared war on

\footnotetext{
${ }^{153}$ Tim Niblock, Saudi Arabia: Power, legitimacy and survival (Routledge, 2004) 28.

${ }^{154}$ Shafi Aldamer, Saudi Arabia and Britain: Changing Relations, 1939-1953 (Ithaca, 2003) 55-56.
} 
Britain, France and Russia in alliance with Germany and Austro-Hungary. In December of the same year, negotiations for a treaty of alliance between Abdul Aziz and Britain were revived which eventually led to the signing of a treaty on 26 December 1915 . The treaty described Abdul Aziz as an independent ruler yet giving the responsibility of the emirate's foreign affairs to Britain in exchange for guarantees against external attacks. The treaty also brought Abdul Aziz access to weapons and subsidies.

Despite the 1915 Treaty, the extent of British involvement with Abdul Aziz remained limited and it was not until 1926 when Abdul Aziz completed his conquest of Hejaz that Britain began a permanent representation in Abdul Aziz's territories. It was evident at this time that the control of Abdul Aziz's external relations was no longer a realistic option for Britain. Abdul Aziz was so intent on expanding his territorial control that the British believed curbing that ambition would be costly. ${ }^{155}$ With that understanding, Britain did not try to restrain Abdul Aziz's territorial expansion into northern and eastern Arabia, leading to the removal of Britain's ally, Sharif Hussain in Hijaz. ${ }^{156}$ Nevertheless, Britain's role in determining the course of Saudi's borders with Kuwait, Transjordan and Iraq was substantial. In February 1926, Britain recognized Abdul Aziz as King of Hejaz, Najd and its Dependencies, and proceeded to negotiate a new treaty which was concluded in May 1927 in Jeddah. This treaty had important aspects to it regarding Iranian-Saudi relations. Below is an overview of this treaty and some of its implications.

The fall of Sheikh Khazal and the impending threat to Bahrain was highly alarming for Abdul Aziz but the disparity of military might between Iran and the Kingdom of Hijaz

\footnotetext{
155 ibid. 55-57.

${ }^{156}$ Madawi Al-Rasheed, A history of Saudi Arabia (Cambridge University Press, 2010) 42-43.
} 
and Najd had eliminated the option of countering Reza Shah militarily. Politically savvy Abdul Aziz, however, masterfully preempted the first formal Iranian claim to Bahrain through 1927 Treaty of Jeddah with the Great Britain. Under this treaty, Britain recognized the "absolute independence of the dominions" of Abdul Aziz and in return Abdul Aziz agreed to respect British treaties with the Trucial Sheikhs. ${ }^{157}$ The Clause 6 of this treaty states that Abdul Aziz undertook "to maintain friendly and peaceful relations with the territories of Kuwait, Bahrain, and with the Sheikhs of Qatar, and the Oman Coast who were in special treaty relations with His Britannic Majesty's Government."158 This treaty was an implicit acknowledgement of Bahrain's sovereignty, thus a challenge to Persian claims in the Persian Gulf including sovereignty over Bahrain and a number of islands in the lower Gulf, namely Greater and Lesser Tunbs and Abu Musa.

In response to the Treaty of Jeddah, the Iranian government emphatically protested the inclusion of Bahrain in the clause on the grounds that this was an infringement of Persia's territorial integrity. ${ }^{159}$ In response, Reza Shah ordered his envoy in Cairo to submit a "memorandum of objection" to the Saudi government and demand the return of Bahrain to the Persian domain of authority. On 26 November 1927, Persia lodged an official complaint with the League of Nations. ${ }^{160}$ The letter cited Iran's earlier protest of 1869 and Lord Clarendon's reply as proof of its proprietorship over Bahrain. In the letter, it was

\footnotetext{
${ }^{157}$ Gary Troeller, The Birth of Saudi Arabia (F. Cass, 1976).

${ }^{158}$ Treaty Series, HMSO, London, 1927, No.25, Cmd 2951 quoted in Niblock, Sate, Society and Economy in Saudi Arabia, 74.

${ }^{159}$ H.A. Baharna, The Legal Status of the Arabian Gulf States (Manchester University Press, 1968) 167195.

${ }^{160}$ FO 416/81: Acting Minister for Foreign Affairs to Sir R. Clive, (November 22, 1927) quoted in Meir Litvak, Constructing Nationalism in Iran: From the Qajars to the Islamic Republic (Routledge, 2017)129.
} 
asserted that a private treaty between Shaykh Isa bin Ali al-Khalifa, the ruler of Bahrain, and the British government was contrary to the territorial integrity of Iran. ${ }^{161}$ Britain, however, denied the validity of Iran's claim ${ }^{162}$ and informed the secretary general that the two countries would resolve the dispute in direct negotiations. ${ }^{163}$ It is believed that Britain disfavored any arbitration by the League of Nations in fear that it would weaken the confidence of the region's Arab rulers who were in treaty relations with Britain, mostly as as a protection against Persian expansionism. Also, Britain worried that giving in to the idea of arbitration could set a precedence for other powers in the region such as Abdul Aziz who might have wished to challenge Britain's position in Kuwait. ${ }^{164}$

In spite of the British denial, Iran insisted on its claim. In the aftermath of the British treatment of Iran in the League of Nations regarding the issue of Bahrain, there are indications that the Iranian government had adopted a deliberate policy of challenging British supremacy throughout Persian Gulf. ${ }^{165}$ These provocative policies compelled the British government to seek resolution to the crisis. The British government prepared several draft treaties for the settlement of issues between Britain and Iran. The main aims of the British government throughout the negotiations were to normalize their position at Hengam Island where they already maintained a naval base; attain Iran's recognition of the

\footnotetext{
161 ibid.

162 Robert Burrell, The Persian Gulf (New York, Library Press, 1972).

163 The League of Nations, Official Journal, May 1928, 605-6; FO 416/82: Sir Austen Chamberlain to Sir R. Clive, January 12, 1928.

${ }^{164}$ Chelsi Mueller, “Anglo-Iranian Treaty Negotiations: Reza Shah, Teymurtash and the British Government, 1927-32,” Iranian Studies, 49.4 (2016) 582.

165 Annual Report on Persia for the Year 1928, in Robert Burrell \& Robert Jarman, Iran Political Diaries: 1881-1965 (London: Archive Editions, 1997) 264-69.
} 
Persian Gulf Arab rulers and Britain's treaty relations with them; obtain a renunciation of Iran's claims to Bahrain, Abu Musa and the two Tunbs; and to reach a settlement on a host of secondary issues such as the issues surrounding the Slavery Convention of 1882, the Zahedan railway, lighting and buoying in the Persian Gulf, the transfer of wireless and telegraph stations, and a settlement of Iran's "war debt." 166 Iran's aims, as described by Teymourtash in his letter on 10 May 1928, were to normalize Iran's status vis-à-vis Great Britain and to secure London's recognition of Iran's "legitimate aspirations," particularly in the Persian Gulf. ${ }^{167}$ Iran wanted to reduce British influence in the south of Iran and secure what it believed to be its rightful place in the Persian Gulf waterway. Iran desired to see all islands in the Persian Gulf, including Bahrain, restored to Iranian sovereignty. Iran wanted full responsibility for policing the Persian Gulf, maintaining lighthouses and buoys and operating telegraph and wireless stations on its territory. Furthermore, it wanted Britain to accept and abide by new restrictions on the use of its port facilities. ${ }^{168}$ Intent on acquiring what Tehran believed to rightfully belong to Iran, Iranian government launched an initiative in 1930 to build a navy to strengthen its position in the Persian Gulf waters.

Iran viewed the Persian Gulf as Iran's rightful sphere of influence, and Reza Shah viewed the ability to bring Iran's influence to bear upon the Persian Gulf contested islands, waterway and littoral states as a vital test of Iran's independence and sovereignty. The Iranian policies toward Muscat and the Arab sheikhdoms of the lower Persian Gulf during

\footnotetext{
${ }^{166}$ FO 416/85: Proposed Anglo-Persian General Treaty presented to Teymourtash on August 10, 1929, in Mueller, "Anglo-Iranian Treaty Negotiations."

${ }^{167}$ FO 416/82: Teymourtash to Sir R. Clive, May 10, 1928, in Mueller, “Anglo-Iranian Treaty Negotiations."

${ }^{168}$ FO 416/87: M. Forughi to Sir R. Clive, August 9, 1930, in Litvak, Constructing Nationalism.
} 
this time became so challenging that Britain sought to compel Iran within the framework of the treaty to recognize its role as protector and sole intermediary in the foreign affairs of these Arab states. Yet Iran's policy, under Reza Shah, was to deny the legitimacy of Britain's claim to protect the Arab rulers of the Persian Gulf. ${ }^{169}$ It appears that this approach was meant as a pressure point in negotiations about the fate of Bahrain. ${ }^{170}$ Nevertheless, the protracted negotiations of 1927-1932 between Britain and Iran failed to produce any agreement. Teymourtash had maintained that the Iranian government "would never agree to a treaty which, on the face of it at any rate, appeared to involve considerable territorial sacrifices." ${ }^{171}$ Iran demanded that as part of any agreement, Britain should recognize at least one of its territorial claims in the Persian Gulf namely Bahrain, Abu Musa or Tunb; however, the British were not willing to consider any of such demands. After hearing several proposals for compensation by Teymourtash, the British came to understand that sufficient compensation in Iran's eyes, was Britain's acquiescence to Iran's rise as a regional power. ${ }^{172}$ Nevertheless, Tehran did not drop its claim to Bahrain until 1970, during the period of British withdrawal from the Persian Gulf region. ${ }^{173}$

\footnotetext{
${ }^{169}$ FO 416/83: M. Pakravan to Mr. Parr, (September 20, 1928), in Mueller, "Anglo-Iranian Treaty Negotiations."

${ }^{170}$ FO 416/84: Sir R. Clive to Sir Austen Chamberlain, January 8, 1929, January 19, 1929, and March 6, 1929, in Mueller, "Anglo-Iranian Treaty Negotiations.”

${ }^{171}$ FO 416/86: Sir R. Clive to Mr. A. Henderson, April 18, 1930, in Mueller, “Anglo-Iranian Treaty Negotiations."

${ }^{172}$ FO 416/85: Sir R. Clive to Mr. A. Henderson, August 21, 1929; and FO 416/87: Mr. A. Henderson to Sir R. Clive, September 18, 1930.

173 Roham Alvandi, "Muhammad Reza Pahlavi and the Bahrain Question, 1968-1970." British Journal of Middle Eastern Studies, 37.2 (2010) 159-177.
} 


\section{Treaty of Friendship: Saudi’s Unilateral Appeasement of Iran}

Reza Shah's challenge of the British influence continued as his suspicion of Britain's role in the region grew stronger. ${ }^{174}$ Interestingly, Abdul Aziz was becoming increasingly skeptical about how much he could rely on Britain to deliver its promises. As the result, Abdul Aziz decided to directly reach out to Reza Shah, the outcome of which was the 1929 Treaty of Friendship. This treaty might have been referred to as a cautious beginning of diplomatic relations between the two countries, which indeed was the case, but what the literature has ignored altogether about this treaty is the fact that it was a classic example of bandwagoning in international relations. Stephen Walt illustrates the causes and pathways leading to alliances in response to threats. According to Walt, states that respond to real or perceived security threats either bandwagon or balance. The balancing behavior, which according to Walt is more prevalent and typically the preferable choice, runs on the balance of power theory and entails forming coalitions against states or a coalition of states posing a threat. Bandwagoning on the other hand, Walt explains, is joining the sources of the threat in hopes that appeasement of the weaker side may encourage the stronger side to divert attention elsewhere. ${ }^{175}$

In the closing years of the 1920s, all crucial elements that Walt identifies for deciding moves towards alliances were in place. Iran's aggregate power compared to Abdul Aziz's state which was in its infantile years had rendered Iran as a potential threat to the

\footnotetext{
174 Shareen B. Brysac, “A very British coup: how Reza Shah won and lost his throne,” World Policy Journal, 24.2 (2007) 90-103.

175 Stephen M. Walt, The origins of alliance. (Cornell University Press, 1990) 17-40.
} 
territories controlled by Abdul Aziz. Persian nationalism which was essentially a blend of anti-colonialism and anti-Semitism was on the rise in Iran and purposively channeled behind Iran's territorial claims and regional aspirations. ${ }^{176}$ On the other hand, Abdul Aziz was facing the Ikhwan revolt beginning in 1927, a nation unwilling to surrender to his authority, and a long way before having his sovereignty consolidated within the territory under his control.

The Ikhwan rebellion in 1929 is among the earliest crisis that Abdul Aziz had to deal with. The roots of this crisis are to be sought in Abdul Aziz's religious crusade that had instilled in the Ikhwan the idea that the days of the Prophet had returned. The Ikhwan was Abdul Aziz's primary means of extending his authority in Arabia through raids on tribes and forcible conversion of them to Wahhabism. However, the boundaries delineated in the period following World War I had effectively prevented further territorial expansion of the Al-Saud's rule to the north and west. Once the Ikhwan stepped over the boundaries into the British mandates, Abdul Aziz had to curb the Ikhwan's expansionist zeal. Britain forced Abdul Aziz to acknowledge fixed borders through a series of treaties with the mandates of Iraq and Transjordan. Abdul Aziz's surrender to the British imposition put Ikhwan's pent-up grievances on fire, leading them to accuse "Saudi Imamate of subverting Islamic ideals," and rebel against both Saudi rule and the British protected territories. ${ }^{177}$

Ikhwan's grievances against Abdul Aziz were older than what immediately caused the rebellion. The beginning of Ikhwan's dissatisfaction with the Saudi rule may be traced

\footnotetext{
${ }^{176}$ The documents of 1927-1932 Anglo-Iranian negotiations reveal the Iranian government's intentional mobilization of such sentiments behind its national and regional causes.

${ }^{177}$ Christine Moss Helms, The Cohesion of Saudi Arabia (Routledge, 2015) 251.
} 
to the successful completion of their campaign against al-Hijaz. After this success, much to the surprise of Ikhwan commanders Ibn Bijad and Faisal al-Duwish, Abdul Aziz did not treat them as they expected. Ibn Bijad had anticipated an appointment as the General Commander of the Saudi forces and al-Duwish aspired for governorship of Medina including surrounding territories and villages. Nevertheless, Abdul Aziz felt insecure in face of Ikhwan's growing strength, hence he decided to reward neither of the commanders. ${ }^{178}$ Ikhwan's grievance of Abdul Aziz grew when Abdul Aziz, in his effort to transition from a religious leader to a political leader, prevented Ikhwan's further massacres and looting in Hijaz, whereas the Ikhwan believed that Hijazis deserved a "divine wrath."

The fanaticism of Ikhwan was no longer appropriate under Abdul Aziz's new policy of reconciliation. In 1925, Abdul Aziz decided to send the Ikhwan empty-handed back to their hijras. The warriors returned home in 1925 only to find that drought had decimated their herds, and their women and children had turned to panhandlers. ${ }^{180}$ Almost a year after, al-Duwish and Ibn Bijad convened a meeting of Ikhwan tribes in 1926 and listed a number of complaints against the Saudi leader, among them allegations of Abdul Aziz's religious laxity; inappropriate treatment of apparent manifestations of disbelief, idolatry and polytheism; giving in to the use of cars, telegraphs and telephones which they referred to as "innovations of the Devil;" and insufficient enforcement of Wahhabism among the Shi'ites in al-Ahsa and Iraq. Once notified of the Ikhwan's gathering, Abdul Aziz responded by convening Ikhwan leaders with Wahhabi ulema in al-Riyadh to issue a fatwa that

\footnotetext{
178 ibid. 252.

179 ibid.

180 Louise Dame, "Four Months in Nejd," The Muslim World, 14.4 (1924) 354.
} 
conceded many of the Ikhwan demands. ${ }^{181}$ The compromise reached in al-Riyadh did not last long. Ikhwan began their raids in growing intensity and savageness on British mandate territories. After several failed efforts by Abdul Aziz to manage the crisis, Abdul Aziz ordered his troops to attack Ikhwan forces on 30 March 1929 in the battle of Sabila to crush Ikhwan decisively. Ironically, Abdul Aziz had to suppress the very force that helped him expand his territorial authority, the force that was founded on the same Wahhabi doctrine that legitimized his own political authority.

Above was only a synopsis of the political circumstances in Iran and Saudi Arabia in the turbulent decade after WWI meant to make the case for the massive discrepancy in the aggregate powers of the two polities. Such power disparity was coupled by the geographical proximity between the two states. This proximity had magnified the gravity of any assault by Iranians since Saudi controlled territories could easily be among the first in Reza Shah's harm's way. The growing power of Reza Shah in the region, his aggressive approach and intentions, the revival of exclusionary anti-Arab nationalist sentiments in Iran, and the British favorable view of him due to coincidence of Reza Shah's power with the British interests had turned Iran into an offensive power able to "threaten the sovereignty or territorial integrity of [neighboring states] at an acceptable cost." 182 Abdul Aziz, being a political savvy, could not afford to overlook these developments.

Cynical of Reza Shah's intentions, wary of Iran's growing power, and disenchanted by the precedence that the British had set in leaving the side of Sheikh Khazal despite all the promises of protection, and Britain's lenience toward Reza Shah over the issue of slave

\footnotetext{
181 See Hafiz Wahbah, Arabian days. (London, Barker, 1964) 133-136.

${ }^{182}$ Walt, The Origin of Alliance, 24.
} 
trades, ${ }^{183}$ Abdul Aziz decided to unilaterally appease Iran. Having realized that the cost of balancing the stronger and seemingly adversarial Iran would exceed its benefits for the infantile Saudi state which was at the time still grappling with domestic challenges, Abdul Aziz sent a Saudi delegation led by Sheikh Abdallah Al-Fadl, the Supervisor of Foreign Affairs, to Tehran on August 10, 1929 to negotiate and conclude a security alliance with the regional powerhouse. This proposal was rejected by the Persian government and as the result the two countries only agreed to the less binding promise of non-aggression, which was a satisfactory progression for Abdul Aziz. However, the Saudi-Iranian Friendship Treaty signed on August 24 set out the basic principles for establishing political, diplomatic and commercial relations between the two countries.

183 The issue of the slave trades in the region was among the important challenges posed by Persia to the British interests in these years. Slave trade was among the most lucrative commercial activities in the Persian Gulf region at the time. Britain had for so long attempted to curb Persia's involvement in the slave trade, but did not put much pressure on the Arabia's slaveholding practice. Persia was a signatory to two anti-slavery conventions with Britain (Wright, The English Amongst the Persians, 70) and in 1926, the Persian government had signed the slavery convention of the League of Nations. Persia objected to the 1882 convention finding it an encroachment on the Persian sovereignty and derogatory to Persian identity. According to the convention, Britain had the right to search Persian vessels on the high seas, both in the Persian Gulf and in Persian territorial waters. Once Persia unilaterally abrogated the convention, Britain showed willingness to give in on searching Persian vessels in return for a reaffirmation of banning slavery by Persia. Nevertheless, British-Persian talks on slavery broke down and the Persians continued to engage in the slave trafficking between Iran and Arabia for some time (See Thomas M. Ricks, "Slaves and slave traders in the Persian Gulf, 18th and 19th centuries: an assessment," Slavery and Abolition, 9.3 (1988) 6070; Jerzy Zdanowski, Slavery and Manumission: British Policy in the Red Sea and the Persian Gulf in the first half of the 20th Century. Ithaca Press, 2012). 


\section{CHAPTER IV}

\section{IRANIAN-SAUDI RELATIONS IN THE 1930S: A CURIOUS CASE OF "DISREGARD" IN FOREIGN POLICY}

From 1929 through 1943, an overwhelming stability in the Saudi-Iranian relations is traceable. The literature on Iranian-Saudi relations typically attributes this stability to the 1929 Treaty of Friendship, which unlike its title was primarily an appeasement of Iranian rising power by the Saudis. Some credence given to the regional order imposed by the British is traceable in the literature as well. There are some merits to these two analyses. Even though 1929 Treaty of Friendship was far from a documentation or an articulation of friendship between the two states, a successful move by Saudis to appease Iran under Reza Shah might have contributed to the stability of the region during this period. On another level, Britain was at the zenith of its hegemonic power, and as the result had effectively constricted the foreign policy of both countries. Unlike Iraq that was hamstrung in its foreign policy-making by the restricting clauses of its 1930 treaty with Britain, Iran and Saudi Arabia willingly refrained from adventurous regional policies in face of disproportionate British strength which kept them in awe. Britain had considerable interests in these two countries and neither of them wanted to jeopardize its relationship with Britain for minor gains in the region. This leverage allowed Britain to create a political order with careful balancing of regional forces. With such a balance, Britain could partially appease Iran and manage Saudi pressures in this decade. There were, however, more nuances to the stability characterizing this period of Saudi-Iranian relations. 


\section{Ontological Security and Saudi Arabia's Quest for Regional Acknowledgement}

Once King Abdul Aziz consolidated his gains domestically and established Saudi Arabia in 1932, he began to look outward. He believed the destiny of the new kingdom entailed an important role in the regional configurations. Matters of behavior predicated on a belief of the trajectory and end-point of one's destiny are typically entwined with a conception of oneself. Self-conceptions could be fragile. They are neither immutable nor imperishable. As a matter of fact, in a social world, the 'conception of self' fades out or simply loses coherence unless they are reinforced by commensurate practices. Accordingly, Abdul Aziz needed to engage in practices that would solidify the vision he had for his kingdom. Even though Abdul Aziz's political experience might have sounded limited to traditional inter-tribal Arab politics, but as Jacob Goldberg documents, he had a solid grasp of the "complexities of international politics" and he mastered the "art of diplomatic negotiations with all the linguistic nuances and subtlety that it entailed." ${ }^{184}$ His pragmatism instructed him away from confronting militarily superior Britain over Saudi’s historical claims of disputed territories of Bahrain and Trucial states, but he found it crucially important to assert Saudi Arabia regionally by engaging Iran in multiple ways.

Considering the messianic zeal that characterized years of Najdi conquest and expansion in Arabia, engaging Iran was extremely important for the Saudi infantile state. This had to with preserving Saudi’s “ontological security."185 Ontological security explain

\footnotetext{
${ }^{184}$ Jacob Goldberg, The Foreign Policy of Saudi Arabia: The Formative Years, 1902-1918 (No. 19). (Cambridge, Mass.: Harvard University Press. 1986), 174.

${ }^{185}$ See Jennifer Mitzen, "Ontological security in world politics: State identity and the security dilemma." European Journal of international relations, 12, 3 (2006): 341-370. Also, Brent Steele, Ontological security in international relations: self-identity and the IR state. (Routledge, 2008).
} 
how routinized social relationships can help sustain 'identity' and a sense of agency through creating "cognitive certainty." Ontological security is about the subjective sense of 'self' and 'continuity' which in a dialectic manner both motivates actions and receives support by sustained actions that are commensurate to that identity over time. Ontological insecurity could be, as Jennifer Mitzen argues, "incapacitating" and leading to agential dysfunction, ${ }^{186}$ that is why establishing or joining routinized social relationships are of great importance. These relationships create a basic trust system ${ }^{187}$ where actors' uncertainty and anxiety for the reproduction of their cognitive world diminish.

The outset of Saudi-Iranian relationships was characterized by mutual skepticism. Following the victory over the Hashemite Kingdom of the Hejaz in 1925, Abdul Aziz established the dual monarchy of the Kingdom of Hejaz and Najd; however, Persia withheld its recognition of that entity until 1929. After the unification of the two monarchies and the official establishment of Saudi Arabia, in May 1932, King Abdul Aziz sent his son Prince Faisal, the viceroy of Hijaz at the time, to meet with Reza Shah. During the visit, Prince Faisal delivered to Reza Shah a personal message from his father and discussed several issues with the Persian Foreign Ministry officials. Even though the entire mission was termed as "successful" in diplomatic parlance, Reza Shah never returned the visit to Saudi Arabia. ${ }^{188}$

\footnotetext{
${ }^{186}$ Mitzen, "Ontological Security,” 345.

${ }^{187}$ Anthony Giddens, Modernity and Self-Identity. (New York: Polity Press, 1991) quoted in Mitzen, "Ontological Security," 346.

${ }^{188}$ Saeed M. Badeeb, Saudi-Iranian Relations 1932-1982. (Al Saqi, 1993), 49.
} 
The customary practice of diplomatic representation and returning official visits are deep rooted in the history of politics. These practices are expected to be carried out honorably and with high respect among states. Breaking from customary diplomatic practices, in any form, is typically a sign of disapproval, discontent, or new direction in foreign policy making, which can have strong and durable ramifications for inter-state relations. The fact that Reza Shah did not act along what is customarily practiced by state officials demonstrates that Abdul Aziz's endeavor to "stabilize" Saudi's identity was not received as anticipated by Persia as a "powerful external [actor]" and in an environment that suggested possible "hostility." 189

Reza Shah's decision not to return the visit was only an instance of a larger attitudinal pattern toward Arabs that characterized Iran's foreign policy in this period. Reza Shah's foreign policy was marked by a dismissive attitude toward Persia's Arab neighbors. According to Saeed Badeeb this attitude was deemed by the Arab states in the region as "hostile isolationism." 190 Such dismissiveness needs to be properly contextualized in before making the case for the relatively stable Saudi-Iranian relations in this period. Two aspects of this context are notable. First, geopolitically, Reza Shah was concerned with interventionist policies of Russia and Britain and the threat they posed to Iran's territorial integrity and sovereignty. The Arab states littoral to the Persian Gulf posed no threat on their own rights in this period. Second, geo-culturally, the growth of anti-Arab sentiments among the nationalist Persian literati who were shaping the discourse of Iranian nationalism in a bottom-up process at the time, coupled with Reza Shah's predilection

\footnotetext{
${ }^{189}$ Mitzen "Ontological Security,” 347.

190 Badeeb, Saudi-Iranian Relations, 48.
} 
towards European-style modernization had him pursue the Persian fate in relation with Europeans and not in dealing with "inferior Semitic folks."

\section{Iran Entangled in Great Power Politics}

Any explanation of Iran's modern history has to account for the role that outside powers played in shaping, or at least influencing, Iranian politics. The geostrategic location of Iran warranted great powers' motivation to impact the course of events in Iran and have them unfold in their favor. Reza Shah's ascent to power took place during and after the First World War when Iran was largely disintegrated as an independent and autonomous entity. Large swaths of Iranian territory were occupied by Russian and British troops in clear violation of Iranian sovereignty and declared neutrality.

Reza Shah had utmost despise of foreigners' influence in Iran. Such resentment of the foreign influence in Iran apparently predated Reza Shah's rise to power. Muhammad Reza, Reza Shah's son, recounts in his interview with Karanjia that his father "resented" receiving orders from Russian officers when he was in the Cossack Brigade, ${ }^{191}$ and as a soldier he would "ponder over... how to minimi[z]e all foreign influence in Persia and rescue at least the army from Russian domination." ${ }^{192}$ In a declaration that then Reza Khan made shortly after his February 1921 coup, he asserted that he desired to "establish a government that [would] not be an instrument of foreign politics." As the king of Persia, Reza Shah routinely lectured the Iranian people against the evil of foreign interference in

\footnotetext{
${ }^{191}$ Rustom K. Karanjia, the Mind of a Monarch. (Allen \& Unwin, 1977), 33.

192 ibid. 34.
} 
the country's domestic affairs, and his desire to end the dependency of his country on foreigners. ${ }^{193}$ An excerpt of one of Reza Shah's speeches is telling in this regard:

I consider myself duty bound to warn the public of the incalculable harm of such dependence and to demand its immediate cessation. No civilized person anywhere in the world should take upon himself the shame of appealing to foreigners in order to attain his aims. It is incumbent on every Iranian to maintain the glory of Iranian history by learning to rely upon himself and upon the powerful force of the nation. The Iranians should be of an independent mind, and should live with an independent will. Compatriots! It is a thousand times better to starve in poverty and destitution rather than prostrate yourself in humiliation before foreigners. ${ }^{194}$

\section{Iran Facing Russia's Aspirations and the Communist Fervor}

Below is a discussion of the gravity of Russia's influence in Iran and Reza Shah's counter-measures. During the 1920s and 1930s, Iran was demonstrably preoccupied with countering Russia's geopolitical aspirations and their ideological thrust. Russian presence and influence in Iran during this period were not unprecedented. In fact, the tragic changes caused by the Constitutional Revolution and its aftermath paved the way for a smooth and sweeping penetration of Russians in Persian politics.

With the unexpected death of Mozaffareddin Shah, his son, Mohammad Ali succeeded to the throne in 1907. Mohammad Ali rescinded his father's agreement to the new constitution which antagonized the constitutionalists. Mohammad Ali Shah sought support from Russia, and the Russians, motivated by their colonial aspirations in Persia

\footnotetext{
${ }^{193}$ Marvin Zonis, Majestic Failure, the Fall of the Shah (University of Chicago Press, 1991) 214.

${ }^{194}$ Donald N. Wilber, Riza Shah Pahlavi: the resurrection and reconstruction of Iran. (Hicksville, NY: Exposition Press, 1975) 73.
} 
and the vagaries of the "big game" among competing imperial powers, obliged. Therefore, in the dusk of the century, Russia and England, longtime rivals in the "Great Game" of influence in the Middle East and Central Asia, took advantage of the unrest and divided Iran into their "zones of influence" with Russia in the north and Britain in the south. In this agreement, the central region was left nominally to the Iranian government as a buffer.

Russians had never been shy expressing what they sought in Iran. In 1904, Russia's foreign minister, Count V. N. Lamsdorf, sent a memo to A. N. Shteyer, his minister in Iran, explaining Russia's aims, "We have tried gradually to subject Persia to our dominant influence, without violating the external symbols of its independence or its internal regime. In other words, our task is to make Persia politically obedient and useful, i.e., a sufficiently powerful instrument in our hands. Economically — to keep for ourselves a wide Persian market using Russian work and capital freely therein.” ${ }^{195}$ By 1914, Russian influence in the Iranian north had become fully entrenched, to the extent that George Buchanan, the British ambassador in St. Petersburg, complained to the Russian tsar that "Northern Persia was now to all intents and purposes a Russian province."196

Buchanan's diplomatic memoirs reveal that Russians entertained the idea of dividing the Persian neutral zone with the British, but the outbreak of war and the Bolshevik revolution curtailed the pursuit of this policy. The Treaty on the Division of Persia (as the 1907 Anglo-Russian Convention was known in Russia) came under fire by the international resolutions that the post-revolution Soviet state adopted. On October 26,

\footnotetext{
${ }^{195}$ Quoted in Aryeh Y. Yodfat, The Soviet Union and Revolutionary Iran (New York: St. Martin's Press, 1984), 6 .

${ }^{196}$ Quoted in Yodfat, Soviet Union and Revolutionary Iran, 8; also George Buchanan, My Mission to Russia and Other Diplomatic Memoirs, 2 vols. (Boston: Little, Brown, and Co., 1923), 1: 169.
} 
1917, the second All-Russian Congress of Soviets passed the "Decree on Peace" declaring the abrogation of all unequal treaties between the tsarist Russia and other nations. Lenin clearly specified in his decree that "in accordance with the sense of justice ... any annexation or seizure of the foreign lands... without precisely, clearly and voluntarily expressed consent $\ldots$ of that nation" under any circumstance was impermissible. ${ }^{197}$ On December 3, 1917, Soviets published the Appeal of the Soviet government "To All Working Muslims of Russia and the East." Among other items, this document called for the annulment of the Treaty on the Division of Persia. ${ }^{198}$ Accordingly, it was decided that once the military activities of the Russian troops in Persia were over, their troops would withdraw and the Persians would be granted the right to freely decide their destiny on their own. ${ }^{199}$ These resolutions were palatable to the Persian government; therefore, it was among the first governments to recognize the Soviet government in December 1917.

Russia's adamant pursuit of its commitments even led to their persistence on including some clauses in the text of the 3 March, 1918 Brest-Litovsk peace treaty signifying the necessity of withdrawing foreign troops from Persia. ${ }^{200}$ The Russian Revolution arguably saved Iranian independence and territorial integrity. Mohammad Taghi Bahar renowned Persian poet, politician, journalist and historian figuratively

\footnotetext{
197 Vladimir Lenin, Decree on Peace. In Second All-Russia Congress of Soviets of Workers' and Soldiers' Deputies (1917, November).

198 Jacob C. Hurewitz, ed. The Middle East and North Africa in World Politics: A Documentary RecordBritish-French Supremacy, 1914-1945, vol. 2 (Yale University Press, 1979), 108-110.

199 Jacob C. Hurewitz, ed., Diplomacy in the Near and Middle East: 1914-1956, vol. 2 (Van Nostrand. 1956) 28.

${ }^{200}$ The Treaty of Brest-Litovsk was signed in the city of Brest-Litovsk between Russia and the Central Powers including Germany and its allies Austria-Hungary, Ottoman Empire, and Bulgaria. This treaty ended Soviet's participation in World War I (1914-18).
} 
captures the sense and essence of the time writing, "two enemies each pulling one side of a rope, were strangling a man. Suddenly, one of them let the rope go and said 'poor man' ... and the miserable man was freed. The man who let the rope go on our throat was Lenin." 201

Just as much the Soviet decision to ease on Persia stemmed from an ideational turn in Russian foreign-policy making after the Bolshevik Revolution, ${ }^{202}$ it was pragmatist. Faced with the civil war, turmoil in Transcaucasia, and the challenge of consolidating its authority over the Russian territory, the Soviet regime found it prudent to court neighboring Turkey and Persia. The Soviet Commissar of Foreign Affairs, Leon Trotsky, as one of the earliest gestures of friendship toward Persia, denounced on 14 January, 1918 the AngloRussian Convention of 1907 and "the preceding as well as subsequent [tsarist] treaties which, in whatever form, limit[ed] and restrict[ed] the right of the Persian people to a free and independent existence." ${ }^{203}$ In a memorandum to the RSFSR government dated 20 January 1918, the Persian government expressed "readiness to start negotiations for concluding new treaties ... on the principle of free agreement and mutual respect of peoples." 204

\footnotetext{
${ }^{201}$ Mohammad-Taghi Bahar, Tarikh-e-Ahzab Siassi [The History of Political Parties], vol.1 (Tehran, 1945), 27.

202 Touraj Atabaki, "Tanavvo e ghomi dar Iran va hoviyat e melli ye Iranian," [Ethnic Diversity in Iran and Iranian National Identity] Iran Nameh, vol. 24, no. $2 \& 3$ (Summer and Fall, 2008).

${ }^{203}$ James Rivs Childs, trans. Perso-Russian Treaty and Notes 1828-1931, Translated from Persian. (1935) 64-65.

${ }^{204}$ Dokumenty vneshne politiki SSSR (Documents of Foreign Policy of the USSR), vol. 1, Moscow, 1957. p. 92 cited in "Iranian-Soviet Relations 1917-1991," http://www.iranicaonline.org/articles/russia-ii-iraniansoviet-relations-1917-1991 retrieved on 08/19/2017.
} 
In February 1918, as the prospects for the Parliament's ratification of AngloPersian Agreement faded, the Soviet government became more insistent in its negotiations with Iran apropos of the promises made. Subsequently, the Soviet government officially ordered the General Headquarters of the Caucasian Front to evacuate the Russian troops from Persia, and by the end of March, the evacuation was over. On June 26, 1918, Foreign Commissar Georgi Chicherin addressed a more explicit note to the Persian government, announcing the voluntary nullification by Moscow of all Russian concessions, debts and special privileges, among them the capitulations. The Persian government responded a month later with a supplementary decision, abrogating all earlier Russian instruments. Yet, the matter was not formally settled until the treaty signed on 26 February 1921 went into effect. $^{205}$

The Russian withdrawal from northern Persia created a power vacuum. This was an opportunity for Britain. Lord Curzon, ${ }^{206}$ defying the British government's desire to constrain commitments in the Near and Middle East, found Persia "the most vital link" in realizing his dream of "creating a chain of vassal states stretching from the Mediterranean to the Pamirs. ${ }^{, 207}$ He seized the opportunity to force Persia into preferential treaty relations with the United Kingdom. The 9 August, 1919 agreement between Great Britain and Persia was the embodiment of this policy.

\footnotetext{
${ }^{205}$ See George Lenczowski, Russia and the West in Iran, 1918-1948 (Ithaca, NY: Cornell University Press, 1949), 94-95 ; Baron Max Beloff, The Foreign Policy of Soviet Russia 1929-1941. Vol. 2 (Oxford University, 1955).

${ }^{206}$ Curzon was the acting British Foreign Secretary at the time.

${ }^{207}$ Harold Nicolson, Curzon the Last Phase 19191925 (London. 1934), 121-122.
} 
In response to the Anglo-Persian Agreement of 1919, the Soviet government in its appeal "To the Workers and Peasants of Persia" made clear that it did not recognize the Anglo-Persia Agreement. Aiming to weaken the British position in Persia and acting from ideological considerations — mainly having the idea of spreading the proletarian revolution to the East — the Soviet leadership started to provide considerable help to the Jangali movement of Mirza Kuchak Khan. ${ }^{208}$ The order of the political office of the Revvoensovet (Revolutionary Military Council) of the RSFSR No. 107, dated October 8, 1920, stated that "political work in the East is the most vital objective for the RSFSR. This work must be taken up with as much determination as was done for the preparation of October."209

Almost three years of negotiations and the "political work in the East" came to fruition with the Soviet-Iranian Treaty signed on 26 February, 1921. This treaty had been prepared and agreed upon prior to the military coup of Reza Khan on 21 February, 1921. The new Persian government sought international recognition; therefore, mutual understanding was advantageous to both states. ${ }^{210}$ According to the terms of the treaty, the Soviet government annulled all its previous treaties with Persia, as well as other treaties of the tsarist government concluded to the detriment of Iranian interests. The treaty lay the ground for the renunciation of all Persian debt and economic concessions to the Russian Tsarist government and/or its subjects, and the return to Persian government of all

\footnotetext{
${ }^{208}$ See Mohammad Shoomij, "barresiye tatbighiye ravabete roosiye e tazari va shoravi by nehzate jangal," [Comparative Study of the Relations of Tsarist Russia and Soviet Union with the Jangali Movements] Tarikhe Ravabet Khareji, no. 30 (2008).

209 “RUSSIA ii. IRANIAN-SOVIET RELATIONS (1917-1991).” Encyclopedia Iranica. http://www.iranicaonline.org/articles/russia-ii-iranian-soviet-relations-1917-1991

${ }^{210}$ Hurewitz, Diplomacy in the Near and Middle East, 90
} 
properties acquired in Iran under such concessions. According to the article 6th of the treaty, ${ }^{211}$ the two states pledged mutual cooperation to prevent their territories to become bastions for any hostile activities targeting the other side. This article entailed an important caveat which provided the possibility of the Soviet troops entering Iranian territory if the Persian government proved unable to avert a foreign attack. Later in the mid-1930s, this controversial clause which was clearly a violation of the Persian sovereignty overturned a trend that bore an improvement of Perso-Russian relations starting in the mid-1920s. ${ }^{212}$

These policies began to be implemented at a time when Reza Khan was consolidating his power and influence over Persia. Even though Reza Khan was concerned over the expansion of communism and even his assassination by agents of the NKVD [People's Commissariat of Internal Affairs] ${ }^{213}$ History of Russo-Persian relations provided ample evidence as to why he could not neglect Russians in either tsarist or socialist guise. In February 1926, Reza Shah made a statement to Sir Percy Loraine which he reported as follows:

...because Persia has to live somehow with Russia, he and his government have got to keep the Russians in play, yielding as little as possible and

\footnotetext{
${ }^{211}$ The 6th Clause of the Treaty reads, "If a third party should attempt to carry out a policy of usurpation by means of armed intervention in Persia, or if such power should desire to use Persian territory as a base of operations against Russia, or if a foreign power should threaten the frontiers of Federal Russia or those of its allies, and if the Persian government should not be able to put a stop to such menace after having been once called upon to do so by Russia, Russia shall have the right to advance her troops into the Persian interior for the purpose of carrying out the military operations necessary for its defense. Russia undertakes, however, to withdraw her troops from Persian territory as soon as the danger has been removed." See British and Foreign State Papers, Vol. 114, pp.901-909.

${ }^{212}$ See Donald N. Wilber, Riza Shah Pahlavi: the resurrection and reconstruction of Iran. (Hicksville, NY: Exposition Press. 1975), 34.; Lenczowski, Russia and the West in Iran, 94-95; Beloff, The Foreign Policy of Soviet Russia.

${ }^{213}$ M. T. Mokhtari, "K voprosu ob otnosheniyakh Irana i Rossii" (About the question of relations between Iran and Russia), Islamskaya Respublika Iran v 90-e gody (Islamic Republic of Iran in the 90s), Moscow, 1998. P.53 cited in "Iranian-Soviet Relations 1917-1991." http://www.iranicaonline.org/articles/russia-iiiranian-soviet-relations-1917-1991 retrieved on 08/19/2017.
} 
leaving the nation through its Parliament free to decide where the limits of national security and essential interest lie. ${ }^{214}$

Reza Shah elaborated on his position to the new British minister, Clive:

The basic thing in the foreign policy of Persia today was to free herself from the danger threatening her from the North and to make herself stronger to resist any pressure which might come from that quarter. Secondly, Persia wished to live on the friendliest possible terms with Great Britain and hoped to draw British sympathy to herself and to be able, should danger threaten imminently from the North, to count of British encouragement if not actually British help to save herself. ${ }^{215}$

Once Reza Shah ascended to the throne, he found normalized relations with the Soviets in the interest of the country. Initially, Soviets were skeptical of Reza Shah due to the role Britain allegedly played in his ascent to power, and the notion that his effort to centralize power in Persia was in line with British hostile policies of containing Russia and curtailing its interests. ${ }^{216}$ Russia demonstrated its disapproval of the turn of events by putting an embargo, without prior warning, on all Iranian exports short of cotton, which was later included in the ban. ${ }^{217}$ This was a considerable blow to the Iranian economy at the time, considering the volume of trade between the two countries. ${ }^{218}$ This view changed, nevertheless, as Soviets found Reza Shah's success in establishing order and eliminating

\footnotetext{
${ }^{214}$ M.A. Medlicott, Douglas Dain and M.E. Lambert, Documents on British Foreign Policy 1919-1939, Series IA, vol. I (London 1966) 812.

215 ibid. Vol. II, 832.

216 There is no evidence documenting the British Foreign Office involvement in the coup but the commander of British military forces in Iran, General Ironside, backed Reza Khan's rise to power in the Cossack Brigade and encouraged him to undertake a coup. See Keddie \& Richard, Modern Iran, 80.

${ }^{217}$ Donald N. Wilber believes that the embargo was due to the fact that Iranian parliament had not ratified a commercial treaty signed between the countries in 1923 and the agreement covering the Caspian Sea fisheries, concluded in 1925 had been rejected by Iran. See Wilber, Riza Shah Pahlavi,121.
}

218 Ali Asghar Zargar in his History of Anglo-Iranian Political Relations during Reza Shah Documents that in 1912, seven years before the Bolshevik Revolution, 74.4 percent of the entire Iran's trade was with Russia. This number fell after the 1919 Revolution to 21 percent which was still substantial. 
British privileges reassuring. This was an enhancement in the Persia's function as buffer state between the two powers. Another reassuring factor was Reza Shah's modernization project which was turning Persian society from feudalism to capitalism. Soviets believed that this would prepare the country for a socialist transformation. ${ }^{219}$

On 1 October, 1927, Persia and the USSR signed two treaties. One of the two treaties, the Soviet Caspian Sea Fisheries Concession in Persia, ${ }^{220}$ addressed the difficulties arising from the stipulations in Soviet-Persian treaty of 1921 regarding Caspian fisheries. By the act of the other agreement, the Treaty of Guarantee and Neutrality, ${ }^{221}$ Persia was brought into Soviet defense arrangements. Accompanying this treaty were two protocols in which the signatories declared that they had "no international obligations whatsoever contrary to the said Treaty and will not undertake such obligations during the whole duration of that Treaty." The signatories also stated the article 6 of the 1921 Treaty continued in full vigor. ${ }^{222}$

These treaties did not placate Reza Shah's skepticism of the Soviets, nor slowed down Russia's intelligence activities in Persia that were at best disruptive if not subversive. In October, 1930, the Agabekov revelations, published first in a series of article in $L e$ Matin, made clear that he had been sent to Iran in the spring of 1927 nominally as an attaché of the Soviet embassy, but in reality as a resident general of the OGPU to improve the

\footnotetext{
${ }^{219}$ Sheerin Hunter, "The Soviet Union and the Islamic Republic of Iran," in Hafeez Malik, Soviet-American Relations with Pakistan, Iran and Afghanistan, (Palgrave Macmillan, UK, 1987), 249.

${ }^{220}$ League of Nations, Treaty series, No. 2621, Vol. 112 (1931) 350-260.

221 ibid, 292-295.

${ }^{222}$ See Baron Max Beloff, The Foreign Policy of Soviet Russia. 1929-1941 (Oxford University Press, 1952).
} 
coordination and efficiency of the Soviet Secret Organization. ${ }^{223}$ The Russian defector, Yuri Agabekov, outlined Soviet aims in Iran and named many agents from the Persian network who worked for him. Agabekov was instructed by Moscow to overhaul the existing OGPU apparatus and to concentrate its attention on the potentially disquieting situation in the northern provinces, as well as to investigate the problems and grievances of the national and tribal minorities. ${ }^{224}$ Particularly alarming was the revelation that the Soviets planned to help Kurdish tribal area secede from Iran. Moscow hoped that this support would encourage the Kurdish tribesmen fight for the Soviet Union, should there be any conflict with Britain. ${ }^{225}$ With that in mind, in 1927, the Politburo had entertained the idea of creating an independent Kurdish Republic of that small part of Kurdistan which lay within Soviet territory. ${ }^{226}$ The purpose of this scheme was to attract Kurdish sympathies in Iran, Iraq and Turkey; and it appeared to be highly favored by the Foreign Department of the OGPU. ${ }^{227}$ This proposal was not followed through. ${ }^{228}$ Instead, the Soviets decided to set up a network of agents among the Kurds in order to conclude a secret alliance with their tribal leaders. In spite of Tehran's slow response to these revelations, this turn of events further corroborated Reza Shah's distrust of the USSR and its subversive activities.

\footnotetext{
${ }^{223}$ Grigorii Agabekov, OGPU, the Russian Secret Terror. (Brentano's, 1931), 127.

${ }^{224}$ Miron Rezun, The Soviet Union and the Iran: Soviet Policy in Iran from the Beginnings of the Pahlavi Dynasty Until the Soviet Invasion in 1941, Vol. 8, (Brill Archive, 1981), 98.

${ }^{225}$ William G. Elphinston, “The Kurdish Question.” International Affairs (Royal Institute of International Affairs), 22,1 (1946), 91-103.

${ }^{226}$ Agabekov, OGPU, 118.

${ }^{227}$ Ibid.

228 ibid.
} 
Irrespective to the distrust Reza Shah felt toward Russians, he opted for keeping the prospect of economic cooperation with the USSR open and strong. The framework of such cooperation was provided on March 1, 1931, when the Persian parliament ratified a treaty of commerce with the USSR. The treaty was highly unpopular among merchants of the northern regions in Iran, ${ }^{229}$ yet Reza Shah's primary concern rested elsewhere, the problematic 1921 Treaty.

Ever since the inception of the League of Nations, Iran had solemnly attempted to uphold the Article 10 of the Covenant being collective security measure with the hope that it would protect Iran against any threat and coercion. ${ }^{230}$ When the USSR joined the League of Nations in 1934, Iran seized the moment and tried to persuade the USSR to eliminate clause 6 from the Treaty of 1921, on the grounds that the Charter of the League of Nations itself guaranteed the members' security. The USSR government turned the request down. The Soviet's refusal to amend the 1921 Treaty following Agabekov's revelations in 1930 adversely affected any further development of relations between the two countries in the years to come. The Soviets had already had their grievances against Reza Shah's repressive measures against Iranian communists, and the latest developments were enough for the Soviet government to expel Iranian migrants from the USSR. Ensuing these developments, the USSR cut down the network of its consulates, and demanded the Iranian government to follow suit. This encounter was the tipping point of relations between the two states in the years preceding the Soviet occupation of Iran during WWII.

\footnotetext{
${ }^{229}$ Wilber, Riza Shah Pahlavi, 145.

${ }^{230}$ See Mojtaba Tooyserkani, "Iran va jame e ye melal" [Iran and the League of Nations] Tarikhe Ravabete Khareji, no. 24/25 (2005).
} 
Persian communist movement was the other major challenge that Reza Shah had to face in connection with the Soviet Union, even though he would not have attested to the gravity of the matter. Once asked whether he thought there was any threat of Bolshevism in Iran, Reza Shah replied, "Not at all" and continued, "Enough Persians travel to Baku and Yerevan to be able to compare the poverty and misery of Russia with the conditions existing in their own country. They are too wise to wish to exchange."231 Reza Shah's policies, nevertheless, proved otherwise. As a matter of fact, the drive against communist and communist sympathizers persisted all along during his reign.

The founding of the Tudeh in 1941 is commonly regarded as the beginning of the modern communist movement in Iran, discounting the old Persian Communist Party, or PCP, founded in 1920, as an organization with few, if any, historical connections to the Tudeh. That is not true. As a matter of fact, the PCP had a strong organizational as well as ideological influence on the formation of the Tudeh. The Persian communist movement, which had strong ties to the Russian Bolshevik party, was born among Iranian workers in the Caucasus. In 1905-1907, Social-Democratic Party of Iran $^{232}$ emerged among those workers. During World War I, the more radical members of the party, such as Assadullah Ghafar Zadeh and Bahram Agayev, formed a clandestine organization, Ferqa-ye 'Adālat (Justice Party). Ferqa-ye 'Adālat later renamed to Ferqeh Komonist-i Iran, or Communist Party of Iran (PCP) in its first congress held on Iranian soil on July $23^{\text {rd }}, 1920 .{ }^{233}$ This

\footnotetext{
${ }^{231}$ Wilber, Riza Shah Pahlavi, 136.

${ }^{232}$ Ferqa-ye ejtemā '`ỳün-e 'āmmīyūn-e İrān

${ }^{233}$ See Mostafa Fateh, Fifty Years of Iranian Oil (Chehr stock company, Tehran. 1956), 262.
} 
congress came on the heels of the Soviet naval forces' entrance at the Persian Caspian port of Anzali in pursuit of the remnants of the White army. The presence of Soviet forces in Anzali substantially reinforced Adalat. ${ }^{234}$

After the 1917 revolution, Adalat joined forces with Bolshevik organizations in the Caucasus, recruiting Persian workers and other immigrants to join in the Russian civil war against the Whites. ${ }^{235}$ Adalat's leading theoretician, Avetis Sultanzadeh was impatient for a world revolution which would extend to Iran. ${ }^{236}$ The party published several newspapers as part of a vast propaganda campaign among Persian immigrants in the Caucasus and Central Asia, with the aim of recruiting them for the "Iranian Red army." Adalat also sent activists to other major towns in northern Persia to revive the declining old SocialDemocratic Party of Iran which had maintained ties with the Persian labor movement from its early days. In Tehran, the PCP formed a parliamentary alliance with the Socialist party which also had historic ties to the Russian Social Democratic party. ${ }^{237}$

At a meeting on 25 January 1922, representatives of the Comintern, the Caucasian bureau of the Bolshevik party, and the various central committees agreed on a new composition of the central committee in Persia. The cornerstone of the new approach was the acceptance of, and operation within, the existing Persian political framework, that is,

\footnotetext{
${ }^{234}$ Ebrahim Fakhra'i, Sardār-e jangal Mīrzā Küček Kāan, (Tehran, 1972). 225-235.

${ }^{235}$ Delegates of Adalat attended the Sixth Congress of the Bolshevik Party, an indication of their strong ideological leanings toward Bolshevism. See, M. Reza Ghods, "The Iranian Communist Movement under Reza Shah.” Middle Eastern Studies, 26, no.4, (1990) 506-513.

${ }^{236}$ Cosroe Chaqueri, Avetis Sultanzade, the Forgotten Revolutionary Theoretician (Antidote Publications, 1985)

${ }^{237}$ Ghods, “The Iranian Communist Movement," 507.
} 
the new government dominated by the commander of the army, Reza Khan, whom the Soviets recognized as "representative of the Iranian national bourgeoisie." During this phase the communist party conducted its activities in semi-clandestine fashion, recruiting and educating new cadres in Persia and striving to spread its revolutionary message. The newspaper Haqīqat (Truth), which began publication on 30 December 1921 under the editorship of Mohammad Dehghn was the principal instrument in this effort. The paper claimed to be the "supporter of workers and labor unions," and its editor had vowed to express "the interests of workers and peasants, preach class struggle, and fight, in the most vigorous manner, against the existing regime."238 Reza Khan closed the newspaper in 1922.

In the ensuing period, the communist party made a concerted attempt to achieve a modus vivendi with the government of Reza Khan. In March 1923 a more moderate communist newspaper, $K \bar{a} r$ (Labor), began publication under the editorship of Abul-Fazl Lesani who praised Reza Khan's "struggle against the landed aristocracy." 239 By the same token, Sultanzadeh, declared that Reza Khan enjoyed "great popularity," and he was an “esteemed politician." 240 Despite this conciliatory attitude, Reza Khan pursued his repressive policy of crushing all labor unions and newspapers with communist tendencies. The breaking point for the party must have come in December 1925, when Reza Khan chose to establish a dynasty, rather than the republic on which both the Soviets and the

\footnotetext{
${ }^{238}$ Kaveh Bayat, ed., Fa àlīyathā-ye komūnīstī dar dawra-ye Reżă Šāh, 1300-1310 [The Communist Activities in Iran during Reza Shah's Reign.] (Tehran, 1992), 117.

${ }^{239}$ Cosroe Chaqueri, “Communism in Persia to 1941.” http://www.iranicaonline.org/articles/communism-i, retrieved on 08/20/2017.

${ }^{240}$ Ibid.
} 
party had counted. ${ }^{241}$ The influence of the communist party on Persian domestic politics in the initial years of Reza Shah's reign was marginal and by the time the party was reorganized in late 1927, all hopes of conciliation with Reza Shah had been lost.

The second congress of the PCP, known as the Urmia congress, revitalized the party for another round of communist propaganda in Iran. In this congress, Sultanzadeh assessed the history of the party since its foundation in June 1920 and emphasized the "revolutionary experience" that the party had acquired "[despite] periods of defeat and division." The representatives at this congress indirectly criticized the Soviets for having fallen victim to Reza Shah's "clever hypocrisy." 242 The congress emphasized the necessity for close collaboration with the peasantry, "the seizure of power in the cities ... with the [help of the] revolutionary segment of the population ... the workers, artisans, and petty bourgeoisie;" and "the penetration of revolutionary ideas into the army and the passing of troops to the side of the people in struggle." ${ }^{243}$ These three elements constituted the party's program of "national revolution." As its immediate tasks, the second congress called for the overthrow of monarchy and abolition of special privilege; establishment of a "popular, revolutionary, independent, and federated republic" in Persia; confiscation of all large landed estates, as well as government properties; nationalization of factories, oilfields, and the installations by the Anglo-Persian Oil Company; and cancellation of all treaties

\footnotetext{
${ }^{241}$ See Chaqueri, "Sultanzade: the forgotten revolutionary," 215-235.

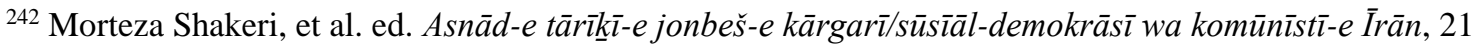
vols. (Tehran, Elm, 1979). 85-115.

243 ibid, 169.
} 
detrimental to Persian independence. After the conclusion of the congress the party manifested a new vigor and energy for activism.

The second congress generated considerable activity among workers, not only in the factories, but also in the tightly controlled oil industry in the south. At the instigation of PCP, on 1 May 1929, Persian workers at the APOC went on strike which was met by the prompt response of the Persian authorities. ${ }^{244}$ The communists, nevertheless, continued their long and patient effort among workers. The next major communist-led strike took place in Isfahan in May 1931, at the Watan textile factory. Reza Shah defeated this oneday strike and crushed its communist nuclei as well. ${ }^{245}$

While party activists in Persia experienced considerable frustration owing to Reza Shah's policy of repression, they made vigorous efforts to recruit students who had been sent by the government for higher education abroad. The recruitment was supplemented by heavy Marxist ideological education and vehement anti-Shah propaganda. ${ }^{246}$ Immediately after the second congress, a brochure announcing the formation of the Revolutionary Republican Party of Iran (R.R.P.I.) was distributed in the West. The R.R.P.I, addressed the "Iranian nation," blaming "the rich and the aristocracy" of the country for the "misery and poverty" of the people. The brochure was an invitation to overthrow the Pahlavi monarchy and replace it with a "national regime." Many of the scholarship students

\footnotetext{
${ }^{244}$ Cosroe Chaqueri. The Conditions of the Working Class in Iran, (Florence, 1978), 52-59.

245 ibid, 43-47, 60-67.

246 Hussein Makki, Tarikh-e Bist Saley-e Iran [Twenty Years' History of Iran] 7 vols. (Tehran: Nashr Publishing Co., 1983) 5:182.
} 
who were recruited in Europe subsequently played decisive roles in the communist movement in Persia. ${ }^{247}$ These recruiting activities supplemented by the distribution of Setāra-ye sork (Red star), the new theoretical organ of the Persian communist party, led to a conference of Persian communist students in Cologne in February 1931. Delegates resolved "to uphold the standard of liberty and revolution [and] . . . to use all in [their] power to overthrow the regime of robbers ... [as] Persia [had to] belong to the laboring masses." Immediately afterward, the newspaper Peykär (Battle) was launched in Berlin with the goal of extending political propaganda against the Pahlavi regime to a wider, nonstudent readership.

The strikes and recruiting activities among Persian students abroad alerted the government to the resurgence of the communist movement. The government in response reinforced the enforcement of repressive measures. In that pursuit, the Parliament passed a bill on June 9, 1931 designed to remedy the fact that the criminal code contained no provision for action against those intending to overthrow the government by force. Although neither communism nor the USSR were cited by name, the intent was clear. In it various clauses, the bill provided for prosecution of individuals preaching the establishment by force of one social class over others, advocating the violent overthrow of the political, social and economic order, taking part in a party or organization planning the separation of any of its territory from Iran or belonging to organizations with any such aims that had branches within and without Iran. ${ }^{248}$

\footnotetext{
${ }^{247}$ Shakeri, Asnād-e tārīkn̄i-e jonbeš-e kārgarī, IX, 93-94.

${ }^{248}$ Wilber, Riza Shah Pahlavi, 142-143.
} 
In 1933, Taghi Arani, Bozorg Alavi and Iraj Eskandari founded a theoretical magazine named Donya [The World] with an aim to propagate Marxism. In 1935, Dr. Arani travelled to Moscow. During the trip, he contacted the officials of the Comintern and persuaded them to assist him in building a new Communist Party in Iran. Following the visit, the Donya group chose a 'Provisional Central Committee', with Arani as SecretaryGeneral until a new Congress of the PCP could be held. The Provisional Central Committee was entrusted with establishing an underground organization capable of operating under Reza Shah's dictatorship, forming unions among workers and students, and organizing Communist Party members. The Provisional Central Committee succeeded in establishing youth and student organizations with established cells on college campuses for the discussion of Marxism and current affairs. Tthe student organization was not devoted solely to theoretical discussions. In 1936, the student union organized a couple of successful strikes which did not invoke Reza Shah's repressive response. ${ }^{249}$ In another attempt, Arani clearly breached a serious red line and tried to organize party activities in Khuzestan which invoked the government's unapologetic response. ${ }^{250}$ In April 1937, the government arrested Arani and 52 of his followers, followed by the trial of 48 of this number in November, 1938 and eventual imprisonment of 45.

Contemporaneous to the arrest of Arani and his followers was the ongoing Stalin's purges in the Soviet Union which cost the lives of many Iranian communist leaders, including Sultanzadeh. The dismantling of the PCP and the liquidation of its leaders in the

\footnotetext{
${ }^{249}$ Nosratollah Jahanshahlou-Afshar, Ma va Biganegan: Sargozasht [The Foreigners and Us: The Story] (Germany, 1982), 15-18.

${ }^{250}$ ibid, 84-85.
} 
Soviet Union did not result in total elimination of the communist movement in Persia. In fact, some of the old cadres and leaders such as Pishevari, Ovanessian, and Eftekhari survived their prison time to form the Tudeh party in $1941 .{ }^{251}$ On 29 September 1941 , only 13 days after Reza Shah's abdication and exile, the Tudeh party was founded by 27 members of Dr. Arani's followers who along with most other political prisoners were released from prison in the wake of the Allied invasion while the 1931 anti-communist act was still in effect.

\section{Iran Facing Britain's Aspirations and Entrenched Interests}

At Loraine's farewell meeting on June 27, 1926, he brought up to the Shah of Iran that Iranian "foreign policy was not clear," an assertion upon which Reza Shah lost his composure and reacted fiercely. Loraine suggested that it was imperative for Iran to seek closer relations with Britain and severe any relations with all state that Britain found objectionable. Reza Shah responded to Loraine saying that "it would appear to my countrymen as if we were subservient to Britain and I would not allow it."252 This was how Reza Shah set the tone for Persia's relations with Britain during his reign. It was obvious from the outset that the British would not find Reza Shah's distinct vision for Persia palatable.

Harold Nicolson who replaced Loraine as the Charge d'Affair at the British Legation, immensely disliked Reza Shah. In a report that he sent out to Chamberlain, the

\footnotetext{
${ }^{251}$ Ervand Abrahamian, Iran Between Two Revolutions, (Princeton University Press, 1982), 139-40.

${ }^{252}$ FO 371/11483, Loraine to Chamberlain, 27 June 1926 quoted in Cyrus Ghani, Iran and the Rise of the Reza Shah: From Qajar Collapse to Pahlavi Power. (IB Tauris, 2000), 388
} 
Foreign Secretary, on September 30, 1926, Nicolson called Reza Shah's "personality...alarming," lacking "intellectual and moral [caliber] necessary for his high functions." Nicolson reported how the "tribes [were] restless... [and] people [were] impoverished and oppressed." However, beneath the altruistic rhetoric, Britain's real intention stands out at the punchline of the report where Nicolson complains that "[Britain's] old tribal friends [had] been sacrificed to [Reza Shah's] policy of centralization." Nicolson vehemently opposed this policy, and rejected Loraine's idea that a "strong and stable Iran would serve Britain's strategic and economic interests in the East. ${ }^{253}$

Soon, Britain was convinced that Reza Shah was intent not to serve the British interest in the region. It is fascinating how Nicolson, representing the British government, had the audacity to "question the value of national independence for Iran." ${ }^{" 254}$ According to Cyrus Ghani, who is among prominent scholars in Iranian studies, British figures such as Robert Byron, Christopher Sykes, David Talbot Rice and Owen Tweedy were discontent with Reza Shah's attempts to "instill self-respect in his countrymen."255 Among such condescending grievances, one can read "emerging Persian arrogance," Reza Shah's imposed "puritanism" as opposed to the "gaiety" of the period, Persians' "insolence

\footnotetext{
${ }^{253}$ ibid, 388.

${ }^{254}$ Nicolson, Curzon, 148

${ }^{255}$ See Cyrus Ghani. Iran and the Rise of the Reza Shah: From Qajar Collapse to Pahlavi Power. (IB Tauris, 2000).
} 
because Reza Shah [had] made them think Persia [was] important," revocation of "extraterritorial rights and privileges for foreigners," etc. ${ }^{256}$

However, Britain's influence in Iran was and remained more entrenched than that of Russia due to their past economic penetration and the control of the southern oil fields in Iran. The concession that William Knox D'Arcy had received in 1901 from the Qajar Mozaffareddin Shah to "explore and exploit" ${ }^{257}$ oil in Iran, discovery of oil in massive quantities in May 1908, the establishment of Anglo-Iranian Oil Company in 1909, Churchill's campaign to replace coal with oil as the primary fuel for the British warships with an aim to help the British navy outmaneuver the German fleets, Britain's decision to buy 52.5 percent of the Anglo-Persian Oil Company in 1914 in order to ensure the British control over Persian oil policies, the Anglo-Persian Treaty of $1919^{258}$ which effectively placed Iran under British tutelage in many ways constitute the course of events that gravitated Britain to Persia, yet eventually made inevitable a clash between the two sides during Reza Shah's reign.

The British had ensured their uninterrupted oil profits by forming alliances with tribal leaders in Persia. Throughout its existence, the Anglo-Persian Oil Company had paid Persia a pittance compared to what it made as profit and paid the British government in taxes. By 1920, a year before Reza Khan's coup, the Iranian position had deteriorated to

\footnotetext{
${ }^{256}$ See Robert Byron, The road to Oxiana (London, 1937, reprint. Random House, 2010), 49; Christopher Sykes, Four studies in loyalty (Collins, 1946), 63-66; D. Talbot Rice, "Introduction" in Byron, The Road to Oxiana, xi; Owen Tweedy, Cairo to Persia and Back (Jarrolds, limited. 1933) 176-181.

${ }^{257}$ Gholam Reza Afkhami, The life and times of the Shah (University of California Press, 2009), 35.

${ }^{258}$ Lord Curzon was the architect of the Anglo-Persian Treaty. His project was to preserve India for England at all costs (the Great Game). In his strategy to establish a cordon sanitaire to separate the subcontinent from putative predators, Iran was critical because it was independent, a rarity in that part of the world, and at the center of the protective belt.
} 
the extent that in the negotiations toward a settlement of disputes with the company, Iran was represented by Sir Sidney Armitage-Smith, a British treasury official. The agreement that had been reached, however, was not ratified by the Iranian parliament, allowing Reza Shah to consider it immaterial. Reza Shah deemed the D'Arcy concession unfair, extracted when Iran had been at its nadir. Soon after coronation, Reza Shah ordered the government to look into the original D'Arcy agreement and renegotiate it. Formal negotiations which began in 1929 and lasted until August 1931 yielded no results. In the meantime, Iran's oil revenues fell by 76 percent from 1930 to 1931 . This was an unbearable loss considering the enormity of Reza Shah's modernization projects.

On November 27, 1932, Reza Shah, presiding over the council of ministers, called for the text of the D'Arcy agreement and records of the discussions and in a fit of anger had them thrown in the furnace that was heating the room. He then instructed the minister of finance, Seyyed Hassan Taqizadeh, to inform the Anglo-Persian Oil Company that the D'Arcy concession was cancelled. ${ }^{259}$ The British government objected to the cancellation on the ground that the agreement stipulated arbitration in case of dispute and threatened to take the case to the Permanent Court of International Justice. Persian government argued that Persia was a sovereign state, and only the Persian courts had jurisdiction in the case. On December 15, 1932, the British took the case to the League of Nations. After some discussion, the president of the League mediated between the Iranian government and the Anglo-Persian Oil Company encouraging both sides to reach an agreement on a new concession. On April 4, Sir John Cadman and Sir William Frazer of the Anglo-Persian Oil

\footnotetext{
${ }^{259}$ Mehdiqoli Hedayat, Khaterat va khatarat [Memoirs and Dangers] (Tehran: Zawwar Press, 1984), 395. The author was the prime minister at the time.
} 
Company arrived in Tehran to begin negotiations. Soon, there was another deadlock but Reza Shah managed to prevail on Cadman, and eventually an agreement in principle was reached on April 21. The Ninth Parliament soon ratified what came to be known as the 1933 Agreement. Cadman later said, "The Shah, and only the Shah, made the agreement possible." 260

The 1933 Agreement, which would later be criticized during the oil nationalization struggles of the 1950s, was celebrated at the time as a success. It significantly reduced the area under concession, increased Persia's revenues, reduced the company's intrusion in local affairs, and made the company's accounts more transparent. It also obligated the company to train Iranians for taking over technical responsibilities, and give priority in employment and promotion to technically eligible Iranians. The agreement increased the lifespan of the concession as well. The original D'Arcy agreement was valid for sixty years, terminating in 1961 and in 1933 more than half of its life had passed. The new concession, valid for another sixty years, extended it from 1961 to 1993 . The issue of the extension was raised toward the end of the negotiations. Even though the Shah initially objected to it, he finally acquiesced because he could not afford to lose the oil revenues in the midst of several development projects. ${ }^{261}$

In 1940, the tension between Iran and Britain flared up over the 1939 fall in Iran's oil revenues, plunge in the value of Iranian currency per pound sterling, and growing

\footnotetext{
${ }^{260}$ Wilber, Riza Shah Pahlavi, 150.

261 See Laurence P. Elwell-Sutton, Persian Oil: A Study in Power Politics (London: Lawrence, 1955); Ronald Ferrier, "The Iranian Oil Industry," in The Cambridge History of Iran, vol. 7. ed. Peter Avery, Gavin Hambly, and Charles Melville (Cambridge: Cambridge University Press, 1991) 7: 639 - 701.
} 
budget deficit. The way Reza Shah conducted his grievances against the British indicates the relative success of his government to extricate Iran from the British influence. Following the negative economic figures, Reza Shah accused the Anglo-Iranian Oil Company (AIOC) of deliberately restricting production, thereby cheating the Iranian government. Reza Shah impatiently demanded a parity of production with the amount of production in $1937 .^{262}$

Disappointed with Britain's failure to honor the terms of the Anglo-Iranian oil agreement that was signed in February 1940, Reza Shah unilaterally cancelled the agreement using a trenchant language that received wide coverage in the Iranian press. ${ }^{263}$ Bullard believed that Britain had to better accommodate Iran in order to preserve the lucrative oil agreement. ${ }^{264}$ It is interesting that in his response back to Bullard, the British Foreign Secretary Lord Halifax dismissed the cancellation of the agreement and instead instructed Bullard to inform the Iranian government that the language and tone of the cancellation had left “the worst impression on His Majesty’s Government."265

Reza Shah increased the pressure on Britain by threatening the oil concession altogether which had the British contemplate accommodating Reza Shah. Bullard was instructed that England deemed the Iranian oil of "great strategical importance [because]

\footnotetext{
262 Afkhami, The life and times of the Shah. 63.

${ }^{263}$ M. Moghaddam to Viscount Halifax, 19 June 1940, No. 1520, PRO FO 371/24572. Cited in Afkhami, The life and times of the Shah. 84.

${ }^{264}$ Bullard to Halifax, 20 June 1940, No. 181, PRO FO 371/24572. Cited in Afkhami, The life and times of the Shah. 84.

265 Halifax to Bullard, 25 June 1940, No. 142, PRO FO 371/24572. Cited in Afkhami, The life and times of the Shah. 64.
} 
oil from other alternative sources [would] have to be bought largely in dollars." However, Bullard was told that "there [were] limits to patience of His Majesty's Government." Matching the rhetoric, the British government authorized Bullard to threaten the Iranian government at his own discretion. He was instructed that "if Iranian Government [did] not share the desire of His Majesty's Government for friendly relations ... His Majesty's Government could and probably would exercise complete control over all exports of oil from Iran." 266

Bullard did not deliver the threat. The British government concluded that they could not risk losing the oil from the world's largest refinery and it was more prudent to honor Reza Shah's demands. Possible cancellation of the oil concession which was an intolerable alternative that Britain wanted to avoid at all costs. The idea of giving in to Iran's demands, however, was repulsive to the British but there seemed to be no other way out of the dilemma. "To give way to the Shah," wrote Chancellor of the Exchequer Sir Kingsley Wood to Lord Halifax, "would create a feeling throughout the East that we are in so perilous a situation that we are ready to submit to any bullying or blackmail, even by a small and poorly armed state such as Iran.” Sir Kingsley Wood believed that this was highly detrimental to Britain's prestige around the world. He wondered whether Halifax would want to take up the matter with the War Cabinet for a thorough debate, ${ }^{267}$ but Halifax strongly opposed incurring unnecessary military risks in the Middle East. Halifax believed

\footnotetext{
${ }^{266}$ Foreign Office to Bullard, 4 July 1940, No. 156, PRO FO 371/24573. Cited in Afkhami, The life and times of the Shah. 64.

${ }^{267}$ Sir Kingsley Wood to Halifax, 22 July 1940, PRO FO 371/24573. Cited in Afkhami, The life and times of the Shah, 64-65.
} 
that it was imperative "to take account of the possible reactions of the Soviet Union if by mischance a serious quarrel with Iran developed." 268

Reza Shah was aware of the quandary that the British were in due to their deteriorating position in the Far East, meaning that Britain could not jeopardize their oil interests in Iran. Reza Shah had said previously that under no circumstance would he accept oil payments smaller than $£ 3.5$ million per year, equal to the amount paid in the peak year of 1937. The Iranian government elevated the pressure even further by asking the AIOC to pay Iran's revenues in gold premium which according to the company's calculations gave him an extra $£ 1.5$ million for the period 1938 to 1941 . At this time, the British had concluded that there was no point in talking to Reza Shah whom Cadman had likened to a "brick wall.",269 On 21 August 1940 the dispute was resolved on the terms favorable to $\operatorname{Iran}^{270}$

The pressure Iran put on Britain in these tumultuous years immensely antagonized the British but they had to bear with Reza Shah's intransigence. Lacy Baggallay of the Foreign Office expressed the sentiment in a note to A. P. Waterfield of the Treasury, "However disagreeable it may be to have to give way to the Iranian demands, the price is on the whole a cheap one when one considers the benefits which we secure from retaining our hold till happier times on this vital supply of oil." ${ }^{271}$ The bitterness between the two

\footnotetext{
268 Halifax to Wood, 26 July 1940, PRO FO 371/24573. Cited in Afkhami, The life and times of the Shah, 65.

269 Afkhami, The life and times of the Shah, 65.

${ }^{270}$ See Final Iranian Government Reply, 21 August 1940, PRO FO 371/24574.

${ }^{271}$ Lacy Baggallay to A. P. Waterfield, 25 August 1940, PRO FO 371/24754, cited in Afkhami, The life and times of the Shah. 66.
} 
states went so far to the point that Britain began to entertain the idea of replacing Reza Shah. From the correspondence between Leo Amery, secretary of state for India, and Anthony Eden, the new British foreign secretary who replaced Lord Halifax, it is clear that at some point, the British even pondered reviving the Qajar dynasty. ${ }^{272}$

\section{Germany as a Balancer, the Final Years of Reza Shah's Reign}

The friction that Reza Shah's increasingly self-assertive foreign policy caused with Britain and the Soviet Union was exacerbated by a German drive for economic, political and military presence in Iran which was welcomed by the Iranian government. Germany could help balance excessive Russian and British influence on Iranian affairs. With that understanding, the Iranian government allowed Germany to become the leading country in Iran's foreign trade from 1939 to 1941, controlling about half of it. Germans made some political advancements as well which met no obstruction by the Iranian side. Reza Shah was not averse to Nazi ideology, language and methods. In fact, Reza Shah personally admired Hitler and found his approach suitable for his dictatorial and nationalistic predilections. So, by the World War II, Iran had already established important economic and political commitments tied to a pro-German policy, while hosting a considerable number of German agents.

Reza Shah thought of Germany and its prospect of winning the war as an opportunity that could ultimately rid Iran of the pressure and influence of the Soviets and British. The pervasive idea was that a victorious Germany would treat Iran differently from

\footnotetext{
${ }^{272}$ See Leo Amery to Anthony Eden, 16 May 1941, PRO FO 371/27196, E 2583; Eden to Amery, 18 August 1941, PRO FO 371/27197, E 4586/3691/G.
} 
the way England or Russia had treated Iran in the past. This was a tough bet. Geographically, Germany was far from Iranian borders, therefore, as long as the war continued, Iran would have to guard its independence and territorial integrity on its own. However, the dazzling events in Europe such as the absorption of Czechoslovakia, the Munich Pact, and Germany's swift move into Poland, and then the fall of Norway, Denmark, the Netherlands, and Belgium looked promising.

Hitler's invasion of Russia on June 22, 1941 drastically changed Iran's strategic position in the war. The pervasive feeling in the Iranian government was that Germany's eventual drive through the Caucasus after defeating the Soviets would return, to a friendly Iran, those areas of the Caucasus and Turkmenistan taken from Iran by the Russian empire early in the $19^{\text {th }}$ century; ${ }^{273}$ however, Reza Shah was aware of the gravity of facing Russia and England without the counterbalance of Germany. As a remedy to the dilemma, Reza Shah ordered his ambassador in Moscow to declare Iran's absolute neutrality. Reza Shah personally talked to the Soviet ambassador to Iran to assure him that he always "wish[ed] to have good, constructive, and cordial relations with the Soviet Union." He wished, he said, to move beyond any misunderstanding that might have existed between the two countries in the past.

Reza Shah promised helping Allies within the bounds of neutrality, but this was not enough for the Allies. In July, Eden explained that Britain is committed to the maintenance of fully independent Iran and the upkeep of its commercial relations, on the condition that Iran expelled the Germans. "There can be no doubt that these persons will be employed

${ }^{273}$ Wilber, Riza Shah Pahlavi, 201 
whenever it may seem fit to the German Government for the creation of disorder either in Iran itself or in the neighboring countries," Eden cabled Bullard. "His Majesty's Government take a grave view of this situation and you should urge upon the Iranian Government the vital importance ... of a drastic reduction of the number of Germans who are permitted to remain in the country. ${ }^{274}$ Similar diplomatic notes were dispatched by Russians to the Iranian government on June 26, July 19 and August 16, 1941.

The growing Soviet-British pressure over Iran was accompanied by the concentration of troops at the borders. Reza Shah had already ordered his government to expel as many Germans as would be possible without appearing to have given in to the Allies' pressure. By the end of July 1941, the British had decided that they probably would invade Iran. The Iranian government kept assuring England and Russia that under no circumstances it would permit the remaining Germans to interfere in Iran's affairs, but to no avail. On August 13, Russia informed England that it was prepared to move into Iran but wanted to coordinate with Britain. On the $16^{\text {th }}$. Britain and the Soviet Union jointly gave Iran another ultimatum demanding the expulsion of all remaining Germans. Iranian government replied that few remaining Germans in Iran are all technicians working in technical and industrial fields, and could not threaten the security of the Allies. On the $19^{\text {th }}$, Eden sent British military and civilian leaders a top-secret cable in which he said that the terms of the Iranian reply were "unacceptable and designed in collaboration with Germans to play for time and that military action should begin as soon as the Russians are able to cooperate." On the $22^{\text {nd }}$, Reza Shah expelled all German nationals not absolutely needed for technical reasons, only to witness the occupation of his country three day later. Reza

${ }^{274}$ Afkhami, The life and times of the Shah. 68. 
Shah's policy was to accommodate the Allies while maintaining Iran's neutrality, but he had misread the Russians and particularly the British. Reza Shah's fundamental problem was who he was, therefore, whatever he did or could have possibly done would not have satisfied the Allies. ${ }^{275}$

Reza Shah's concern for Iran's foreign relations, its sovereignty, and destiny among European and Asian great powers haunted his reign. Under Reza Shah, Western incursions became far more indirect than before,${ }^{276}$ and in spite of rapid growth in foreign investments, particularly in the oil fields, transportation and communication infrastructures, he managed to establish and retain significant political independence. Reza Shah managed to abrogate all foreign capitulations in $1928,{ }^{277}$ and many other concessions by 1933 . Considering political circumstances in the early 1920s Persia, Reza Shah's achievements in this regard are notable.

\section{Anti-Arab Sentiments: The Fate of Aryans Rests Elsewhere}

Along with the geopolitical exigencies of the time, there was an ideational layer to the Iranian government's avoidance of Saudi Arabia. This ideational layer rests on growing anti-Arab sentiments in Iran at the turn of the century, upon which Reza Shah developed a vision of Persian prosperity that was achievable only through an engagement with racially

\footnotetext{
275 ibid., 68-71; See also Mohsen Ganjbakhsh Zamani, "Hozure almanihaye moghime iran: bahane I baraye eshale iran dar jange jahani dovvom," [The Presence of Germans in Iran: A Pretext for Occupying Iran During WWII] Tarikhe Ravabete Khareji, no.28 (2006).

276 Keddie and Richard, Modern Iran, 86.

277 See Ali Bigdeli, "farayande sheklgiriye kapitolasion va laghve aan dar iran" [Capitulations in Iran, Processes of Formation and Collapse] Tarikhe Ravabet Khareji, no. 18 (2004).
} 
up-to-par Europeans and not "inferior Arab folks." Vanessa Martin describes the "presiding ethos" of the Reza Shah's era "a militant form of secular nationalism, with a vision of Iran regaining the glories of its pre-Islamic past." ${ }^{278}$ Sandra Mackey provides the same impression of the time:

Reza Shah launched his attack on Islam by painting the religious leaders as symbols of the old, impotent Iran and himself as the great deliverer of the nation. Freeing Iran from the stultifying influence of Islam, the shah would gain his authority as the leader of a modernized state protected by a mechanized army, not as the "Defender of the Faith" or the "Shadow of God on Earth." 279

Concomitant to this form of "militant secularism" and glorification of pre-Islamic ancient Persia was a rejection of Islam and Arabs on the belief that they were the main culprits in bringing Iran to its ruin. The lamentable state of Persia during the rule of Qajar dynasty encouraged some intellectuals to search for a remedy to the country's inferior world standing. In their diagnosis, these intellectuals found Islam and Islamic culture as the sources of all ills. In their view, the reason that Iran was embarrassingly backward in the $19^{\text {th }}$ century had to do with the "savage" Arab invasion that replaced the "peaceful and civilized" Persian culture with one of "vulgarity," "violence," "superstition," and "backwardness." In response, an attempt was made to rescue Iran from such a legacy by bringing back the pre-Islamic Iran to the limelight. ${ }^{280}$

\footnotetext{
${ }^{278}$ Vanessa Martin, Creating an Islamic State: Khomeini and the Making of a New Iran (London: I. B. Tauris, 2000), 13.

${ }^{279}$ Sandra Mackey, The Iranians: Persia, Islam and the Soul of a Nation, (Penguin Group, 1996) 176.

${ }^{280}$ Kamran S. Aghaie and Afshin Marashi, Rethinking Iranian Nationalism and Modernity (University of Texas Press, 2014), 255-256.
} 
This cultural/intellectual (re)articulation preceded the political manifestation of Iranian nationalism by at least two generations. Therefore, in order to fathom the context to the rise of Iranian nationalism informed by the Persian pre-Islamic legacy, it is important to briefly examine the efforts of those who tried to cast a new conception of Iranian nation through a complex synthesis of traditional Iranian myth narratives and new European styles of thought long before Reza Shah's employment of that narrative. ${ }^{281}$

The genealogy of this (re)articulation began with cultural innovators such as the Qajar Prince Jalal al-din Mirza, Mir Fath'ali Akhundzadeh, Hassan Taqizadeh, and Mirza Aqa Khan Kermani who were among the most active participants in constructing a history of Iran that idealized the pre-Islamic period as the period of prosperity, glory and progress. ${ }^{282}$ Their writings reflect a synthesis of cultural and religious heterodoxy with European orientalism, anthropology, and historiography.

Educated at the Dar al-Fonun, ${ }^{283}$ Jalal al-Din Mirza — one of many Fath Ali Shah's sons - was among the most important figures of the time to articulate a modernist construction of Iranian national history. Mirza's Nameh-ye Khosravan includes indications of the experimental and heterodox ideas that were beginning to circulate among a small sector of Iranian intellectuals during the Qajar period. Nameh-ye Khosravan is an

\footnotetext{
${ }^{281}$ Afshin Marashi, Nationalizing Iran: culture, power, and the state, 1870-1940 (University of Washington Press, 2011), 57.

${ }^{282}$ For a thorough examination of the nature of the thought of many of these intellectuals, see Marashi, Nationalizing Iran, 49-85.

${ }^{283}$ The Dar al-Fonun was established in 1851 by the reforming Qajar minister Mohammad Taqi Khan Amir Kabir as an institution of modern learning to train the members of the Qajar elite for careers in government service. On the Dar al-Fonun, see Fereydun Adamiyat, Amir Kabir va Iran (Tehran: Chap-e Ruz, 1954), 174-90.
} 
imaginative narrative of Iranian history which portrays a host of influences that informed the narratives of an emerging modern Iranian intelligentsia who aimed to (re)construct Iran as a modern nation capable of serving as a political subject of history. ${ }^{284}$ A key feature of the Nameh-ye Khosravan was the inclusion of images and visual motifs from Iranian antiquity which helped forge a direct link between the viewer and the pristine past, assisting them in embracing the cultural renaissance that was underway. ${ }^{285}$ Name-ye Khosravan projects Iran as an indivisible conceptual-territorial entity whose historical continuity was only momentarily disrupted by the Arab-Muslim invasion and the Mongol assaults. As possessor of an autonomous and continuous history, Iran, Jalal al-Din Mirza argued, could reclaim its core identity and national essence whose authenticity had remained intact despite the vicissitudes of history.

Mirza Fath Ali Akhundzadeh (1812-1878) was among the most important figures to participate in the Iranian national revival. His literary works played a significant role in constructing a classical past as the basis of modern Iranian national identity. ${ }^{286}$ These works reflect a romanticized notion of a classical past and a racialized understanding of culture. In his construction of Iranian political-historical consciousness, Akhundzadeh decried an association of Arab cultural and ethnic characteristics with anti-modern Islamic practices. He was convinced that the deplorable condition of Persia was due to its long association with Arab-Islamic culture. Therefore, he called for dissociating Iran from its Arab-Islamic

\footnotetext{
${ }^{284}$ Jalal al-Din Mirza Qajar, Nameh-ye Khosravan, vol. 1 (Tehran, 1869) as seen in Marashi, Nationalizing Iran.

${ }^{285}$ Benedict Anderson, Imagined Communities (Verso Books, 2006), 175.

${ }^{286}$ Mirza Fath 'Ali Akhundzadeh, Tamsilat: Seh Namayesh va Yek Dastan (Tehran: Entesharat-e Kharazmi, 1977).
} 
heritage in order to revive "authentic Iran." He believed that only through what he called an "Islamic Protestantism," 287 the reconstruction of Iranian identity would be possible. Iranian authenticity, in his view, had a natural affinity with ethos of modernity, unlike inauthentic, anti-modern, Arab-Islamic elements in Iranian culture. His most important work Maktubat-e Kamal al-Dowleh ${ }^{288}$ which is one of the earliest challenges to the Islamicate narratives of Persian history reflects this fervor. Maktubat is a lamentation of the state of Iran's once elevated civilization. In the iconoclastic tone with which Akhundzadeh treats Islam and his racial undertone in his polemics against Arabs, one can trace the likes of Ernest Renan's treatment of Catholicism, and popularized Aryan mythology implying distinct and sublime social and cultural practices of Aryans. ${ }^{289}$ Accordingly, his articulation of Iranian national-cultural imagining entailed purging the pristine essence of Iranianness from Semitic Arab and Muslim heritage woven into the fabric of Iranian culture. His harsh tone and pronouncements, his deliberate word choice, and the nature of criticisms he espoused fit his radical approach in deposing the "impediments of progress." He portrays in his various works how the Persian glorious

\footnotetext{
287 "Islamic Protestantism" was a recurring theme in Akhundzadeh's writings. In his autobiography, for example, he discussed the reasons for writing his Maktubat-e Kamal al-Dowleh: "In order to change the basis of this religion [Islam] . . . and for the awakening of the peoples of Asia from entrenched sleep and ignorance and for promoting the emergence of Protestantism in Islam."

${ }^{288}$ Mirza Fath 'Ali Akhundzadeh, Maktubat-e Mirza Fath 'Ali Akhundzadeh, ed. M. Subhdam (German, 1985).

${ }^{289}$ Aryan theory, predicated upon ethno-linguistic genealogy of mankind, was proposed first by Sir William Jones in 1786 and later confirmed further by the work of Schlegal, Bobb, and Grimm among others. The reading of Jones' conception of ethno-linguistic genealogy which was predicated on a monogenetic conception of humankind with arguably reconcilable differences was distorted by the proponents of the politics of romantic nationalism. For them, Jones' findings were no longer representative of the common history of humankind but the basis for constructing new hierarchies of racial-linguistic value. The most powerful of these was the division separating the Semitic from the Indo-European ethno-linguistic groups. In other words, Jones' hypothesis turned into scientific confirmation of national distinctiveness to be consumed by a mass audience; On the ramification of Aryanism in Europe, see Leon Poliakov, The Aryan Myth: A History of Racist and Nationalist Ideas in Europe (New York: Barnes and Noble Books, 1996).
} 
kingdom of perfect justice ${ }^{290}$ was brought to decline by the "violent assault"291 of "barefoot and hungry Arabs." ${ }^{292}$ Akhundzadeh's contribution to the nationalist project was one of infusing modern standards of progress with a mythic antiquity.

Hassan Taqizadeh played an active role in the 1905-1911 constitutional struggle in Iran, distinguishing himself as a strong advocate of the constitutionalist cause against the increasing autocracy of the Qajar rule. ${ }^{293}$ Taqizadeh was among the most politically conscious intelligentsia of his time. He was "capable of inspiring great enthusiasm ... [and] sacrifices." ${ }^{294}$ In 1906, Taqizadeh was elected as a representative of Tabriz to the first Iranian parliament. ${ }^{295}$ His criticism of Qajar autocracy and clerical conservatism made him the target of attacks by both fronts which eventually encouraged him to leave Iran in October $1910 .^{296}$ Taqizadeh lived in Istanbul, Paris, London and New York before he arrived in Berlin on January 9, 1915. ${ }^{297}$ Once in Berlin, Taqizadeh immediately began to gather a circle of agitators and intellectuals to cooperate with the Germans in charting a new nationalist course for Iran. ${ }^{298}$ This circle established the "Iranian Committee for

\footnotetext{
${ }^{290}$ Akhundzadeh, Maktubat. 17-18.

291 ibid, 31-32.

292 ibid, 20.

${ }^{293}$ Homayoun Katouzian, Seyyed Hassan Taghizadeh, Se Omr Dar Yek Zendegi, [Seyyed Hassan Taqizadeh: Three Lives in One Lifetime] Iran Nameh, vol.21, no. 3 \& 4. (Summer, Spring 1993).

${ }^{294}$ Edward G. Browne, E. G. \& Abbas Amanat, The Persian Revolution Of 1905-1909. (F. Cass, 1996), 145.

${ }^{295}$ Iraj Afshar, Iraj. (ed) Zendegi-ye Tufani: Khaterat-e Sayyed Hasan Taqizadeh, (Tehran: 'Elmi, 1993), 59 
Cooperation with Germany" which undertook a series of initiatives against British interests in Iran. ${ }^{299}$

The Iranian Committee began the publication of a semimonthly Persian-language periodical called Kaveh, ${ }^{300}$ under Hassan Taqizadeh's editorship. Kaveh, one of the weightiest voices of nationalism, combined markedly pro-German political coverage of the war with cultural, historical, and literary articles referencing Iranian antiquity. Kaveh bridged the foundational work of the earlier generation of nationalists with the statist project that was to emerge with the ascendance of Reza Khan. The burgeoning of a journalistic print culture was conducive to Kaveh's success in circulating the novel articulation of nationalist narrative beyond the culturally heterodox elites, making it more accessible to a broader audience. Kaveh employed a populist language to situate an invocation of Iran in a romantic construction of mythic antiquity within a modernizing agenda. ${ }^{301}$ By juxtaposing the present against a mythic antiquity infused with modernist values and standards, Kaveh made the present recognizable as a moment of decay that had to be transcended. Kaveh aimed to bridge "an immemorial past... [to] a limitless future." 302 This was a profound historical consciousness with important political implications. The politicized version of this organic conception of political community which was slowly

\footnotetext{
299 ibid. 185.

300 This periodical was published from January 1916 through March 1922. The selection of Kaveh as the name of the newspaper was not accidental. Kaveh was, "according to the ancient legends, a blacksmith from Isfahan who launched a national uprising against the evil foreign tyrant Zahhak, expelled the foreigners and restored the pure race of the Iranian Fereydun to the throne, and achieved independence for Iran.” Kaveh, January 24, 2016.

${ }^{301}$ Nader Entekhabi, "Nationalism and Tajaddod dat Farhang Siaisi after Mashrootiyat," [Nationalism and Modernization in Iran's Post-Constitutional Political Culture] Iran Nameh, vol.11, no.2 (Spring 1993).

${ }^{302}$ Anderson, Imagined communities, 11-12.
} 
pieced together from a newfound awareness of Iran's pre-Islamic past became an increasingly ubiquitous model by the beginning of the twentieth century leading directly to the rise of the Pahlavi state.

During this transitional period, Mirza Aqa Khan Kermani, ${ }^{303}$ the prolific intellectual reformer of late $19^{\text {th }}$ century played an important role. ${ }^{304}$ Kermani's reformist ideas along those of his contemporaneous intellectuals set the stage for the Constitutional Revolution of 1906. In the same vein, he had an idealized image of pre-Islamic Iran for its geographic vastness, the virtues and mercy of its kings who were aided by wise court advisors and Zoroastrian clergies, the order of her fighting men, and the all-encompassing rule of law that governed her lands. ${ }^{305}$ Kermani believed it was the invasion of barbaric Arabs and their institution of an unjust rule that were responsible for the lost glory and the problem-riddled Iranian society. ${ }^{306}$ Kermani was convinced that Islam and the "inferior" Arabs destroyed the populous, prosperous and powerful Persian Empire and its greatness. Kermani viewed the influence of Arabic far worse than Mongols' carnage in Iran and rebuked Arabs for debasing Iranians moral characteristics. ${ }^{307}$

After the collapse of the Qajar dynasty and the constitutionalist projects, built upon half a century philosophical/intellectual effort to (re)construct Iranian nationalism, political

\footnotetext{
${ }^{303}$ For an overview of the Kermani's writings, refer to Iraj Parsi Nejad, "Mirza Agha Khan Kermani," Iran Nameh, vol. 8, no.4 (Fall 1990).

${ }^{304}$ See Fereydoun Adamiyat, Andishehaye Mirza Agha Khan Kermani [The Ideas of Mirza Agha Khan Kermani] (Tehran, Pirouz Publication, 1962).

${ }^{305}$ Mirza Aqa Khan Kermani, Seh maktub [Three Letters], ed., Bahram Chubineh. (Nima Verlag, 2000), 129.

${ }^{306}$ ibid, 132, 142.

307 ibid.
} 
dynamics swayed toward a model of political community that could impose political order and offer a new cultural synthesis to mediate the relationship between state and society. Reza Khan emerged out of such political dynamics. He made use of the nationalist narrative that had been developed since the late nineteenth century in order to cast a new relationship between state and society.

Xenophobic nationalist sentiments kept rising into the 1920s. This was catalyzed by intellectuals and the press propagating anti-clericalism, hostility to the Muslim Arab conquest of Iran, and glorification of pre-Islamic Iran. The radical anti-Arab and antiIslamic ideas of Kermani and others were expanded by a number of twentieth-century writers and intellectuals - notably Sadeq Hedayat, Ahmad Kasravi, and Bozorg Alavi. While there was no freedom of press in this period, newspapers of varying orientations continued to publish. Many of these journals along with some others that were published abroad had a role in propagating and reinforcing nationalist sentiments by reminding masses of the past glories and long-forgotten virtues of Persia. ${ }^{308}$

Reza Shah's vision of the country, its calamities, potentials and destiny did not accidentally coincide with the ideas and ideals of his contemporaneous intellectuals, rather his disdain of Islam and Arabs was fed by figures with demonstrable anti-Islam and antiArab predilections. Reza Shah habitually sought tales of history from figures such as Adib al-Mamalek, Abdollah Mostofi, and Ahmad Kasravi who portrayed for him an idealized

\footnotetext{
${ }^{308}$ For instance, the journal called 'Iranshahr,' edited in Germany 1922-27 by Hossein Kazemzadeh was widely read in Iran. Iranshahr advocated secular nationalism, including universal secular education, women's rights, and Farsi-oriented centralization at the expense of local languages. Keddie and Richard, Modern Iran, 83.
} 
image of the pre-Islamic Iranian past. ${ }^{309}$ Therefore, Reza Shah was socialized into the nationalistic discourse of the time which he found extremely appealing, if not convenient. The main appeal of an idealized distant past is that a great variety of values may be read into it, while the evils of the present could be ascribed to a deviation from that ethos. Reza Shah picked up pre-Islamic Iranian nationalism and made it a foundation of anticlerical monarchism, which by association was anti-Arab. According to Tajolmolouk, ${ }^{310}$ Reza Shah was not religious but in his irreligiosity one could find traces of anti-Arabism or a conflation of the two. He apparently used to sarcastically say "There is no point to speak to God in Arabic everyday unless God is Arab." She narrates that he used to say, "Islam is the religion of the bedouin [pejoratively used] Arabs and long before they knew God, Iranians were devout worshipers and had their own prophets." ${ }^{311}$ In another instance, Tajolmolouk quoted Reza Shah saying that “Arabs [were] Iran’s historical enemies, and the one and only misfortune of Iran [was] having to live by Arabs." 312

\section{Conclusion}

In this chapter, a puzzling period of Iranian-Saudi relations was analyzed. What characterizes the puzzling nature of this period was Persia's policy of avoiding any

\footnotetext{
${ }^{309}$ Memoirs of Pahlavi Queen, Tajolmlouk Ayromlou, (Beh Afarin Publications, 2001) 242.

${ }^{310}$ Tajolmolouk Ayromlou (1896-1982) was Reza Shah's first wife and the mother of Mohammad Reza Pahlavi.

${ }^{311}$ Memoirs of Pahlavi Queen, 242.

312 ibid. 303.
} 
engagement with infantile Saudi Arabia. In order to give presence to Saudi entity in the region and reaffirm their assumed identity, Saudis desired to engage Iran but much to their disappointment, Persia did not reciprocate that desire, making a curious case of 'disregard' in foreign policy. The case was made that geopolitically, Persia's primary concern rested with the threats posed by Russia and Britain. To be more precise, there was neither any real or perceived threat posed by the neighboring Arab states that would amount to that level of gravity, nor these states could be part of any solution to Persia's affliction with RussoBritish interventionist policies. The composition of the 1937 Saadabad Pact, the only security pact that Iran entered in this period attests to the latter clam. ${ }^{313}$ This pact which was a treaty of nonaggression was signed among Iran, Iraq, Turkey, and Afghanistan, leaving out Saudi Arabia. ${ }^{314}$ Reza Shah's hallmark of foreign policy during his reign was playing Russia and Britain against one another. In fact, nothing amounted to that level of urgency in Iranian foreign policy making than to find a way to rid the country from the menace of foreign influence or at least ameliorate its impact by balancing the two powers. In these calculations, there was no place for the infantile state of Saudi Arabia.

Going forward, an ideational/geo-cultural layer of analysis was added to make the case for how a gradually dominating narrative of Iranian nationalism predicated on a romanticized notion of glorious pre-Islamic Persia - which was essentially anti-Arab informed Reza Shah's European-style modernization and the pursuit of the Persian fate in relation with Europeans and not "racially sub-par Arabs." The (re)construction of Iran's

\footnotetext{
${ }^{313}$ See Alireza Bigdeli, "peyman e saadabad” [Saadabad Pact] Tarikhe Ravabete Khareji, no. 9 (2001).

${ }^{314}$ League of Nations, Treaty Series, No. 4402, vol. 190 (1938), pp. 21-27. The Saadabad Pact's most important feature was an agreement by Iran, Iraq, and Turkey to stop using the Kurds to foment trouble for each other and instead to work together to stifle Kurdish dissent. See also Survey of International Affairs, 1936, pp.793-803.
} 
classical past as an epoch in which the nation existed in its homogeneous and unsullied form was the foundation of the nationalist discourse that emerged out of a complex interplay between mobilized myths and legends representing pre-Islamic Iranian culture and an appropriation of racialist Aryanism. ${ }^{315}$ This essentially anti-Arab discourse defined Reza Shah's foreign policy toward Arab states, specifically Saudi Arabia.

${ }^{315}$ Marashi, Nationalizing Iran, 55. 


\section{CHAPTER V}

(1944-1960): WWII-STIRRED SHIFT OF POWER BALANCE AND THE SPILLOVER EFFECT OF NASSERISM \& ARAB-ISRAELI CONFLICT

\section{Test of the Treaty of Friendship, Halting of Diplomatic Relations at a Hajj Incident}

Saudi-Iranian political relations remained stable until December 1943, when the Saudi police arrested an Iranian pilgrim inside the Great Mosque in Mecca for defiling the area around the Ka'bah. ${ }^{316}$ In a letter sent to the Saudi Foreign Ministry on December 12, 1943, Iranian embassy vigorously reacted to the arrest, prosecution and later execution of the culprit of this incidence, and threatened repercussions. The Saudis denounced the Iranian claims and right to prosecute the case. The subsequent correspondence between the two states only escalated vitriol to the point that the Iranian government threatened to "review the continuance of its relations with the Government of Saudi Arabia." 317 The clash between the two countries grew beyond rhetoric and the two sides eventually recalled their representatives and broke off diplomatic relations in March 1944. Later, Iran and Saudi Arabia entrusted the representation of their interests to Egypt and Lebanon respectively.

The fact that the entire diplomatic relations between the two countries could easily come to a halt over the Hajj incident demonstrated the fragility of the 1929 Friendship Treaty. The striking aspect of this encounter between the two countries was the way that

\footnotetext{
${ }^{316}$ Um Ul-Qora (newspaper), no.990, (17 Dec. 1943) (Official Notice, No, 82).

317 (Translated text of letter No. 77H/186, dated 2 Feb. 194, from the Iranian Embassy in Saudi Arabia to the Saudi Foreign Ministry
} 
Saudis handled the matter. Saudis were emboldened ${ }^{318}$ and resolute to treat the incident as a matter of national sovereignty irrespective to what the Iranian government thought would be the more proper course of action. This reality was indicative of a gradual shift in the relative power of the two countries during the Second World War.

In 1939, both Iran and Saudi Arabia announced their neutrality towards the warring coalitions at the beginning of the Second World War; however, they experienced the war years very differently. The European Allies including the Soviet Union did not take the neutrality announcement by Iran seriously. Perhaps due to the pre-war relations of Iran with Germany, and Reza Shah's admiration of Hitler's personality and his ultra nationalist rhetoric, ${ }^{319}$ Iran became occupied in 1941. Mohammad Reza who ascended to the throne after the abdication of his father in the aftermath of the Allies' occupation of Iran was too inexperienced to be able to safely navigate the country through the troubled waters of the war years. The Second World War damaged Iranian economy, fragmented the military force and created the condition of potential domestic instability. ${ }^{320}$

Saudi Arabia’s war-time experience was drastically different. Abdul Aziz had relinquished his normal diplomatic and commercial relations with Germany, and instead sided with the Allied forces. Saudi government allowed Britain and the United States to fly over Saudi territory, and facilitated Soviet re-supply efforts that the Allies were running up

\footnotetext{
318 Towards the end of the 1930s, however, the British began to realize that the international conditions required Britain to find a strong Arab ally. This led to Britain's willingness to compromise with Abd AlAziz, because of his expert knowledge and use of tribal politics, in order to ensure his continued friendship. This factor also contributed to Saudi Arabia's confidence to make a noticeable entrance in the region's inter-state relations by engaging Iran.

${ }^{319}$ Dillip Hiro, Iran under the Ayatollahs (Routledge Revivals, 2013) 29.

${ }^{320}$ See Hossein Abadian, "Ghodrathaye bozorg va eshghale iran dar jange jahaniye dovvom," [Great Powers and the Occupation of Iran during WWII], Tarikhe Ravabete Khareji, no. 28 (2006).
} 
the Persian Gulf. These measures gained the Allies' confidence and precluded the occupation of Saudi territory. As the result, the Saudi monarchy came out of the war stronger and more confident. The way the incident of Hajj in 1944 was unfolded between Saudi Arabia and Iran can reasonably be explained by the deterioration of Iran's power relative to the growing power of the Saudis. In the incident of Hajj, Saudis seized the opportunity to assert their regional power once they realized that the country is run by an inexperienced young king, and that Iran had turned into the "Persian Corridor" ${ }^{321}$ for the British aid and American supplies to the Soviet Union during the war. The estrangement continued until October 15, 1946, when King Abdul Aziz sent a personal letter to the Shah of Iran, urging the renewal of the Saudi-Iranian relations based on the old ties. Iran responded favorably to the Saudi initiative in renewing diplomatic relations which took place in early $1947 .{ }^{322}$

After the resumption of diplomatic relations, the overall Saudi-Iranian relations gradually strengthened up to early 1960s except with the occurrence of minor setbacks. Iranian-Saudi security interconnectedness in years following the end of the WWII was directly impacted by the exigencies of the post-World War/Cold War international security. The real security concerns in both Tehran and Riyadh rested in (re)positioning their respective states in the post-WWII world order. During this period, Iran and Saudi Arabia both converged and diverged policies on a number of issues; however, the realities of the new era overshadowed these policy practices and neither gained momentum enough to

\footnotetext{
${ }^{321}$ Robert W. Coakley, The Persian Corridor as a Route for Aid to the USSR (Center of Military History, 1990); TH Vail Motter, The Persian Corridor and Aid to Russia (Office of the Chief of Military History, Department of the Army, 1952).

${ }^{322}$ Saeed M. Badeeb, Saudi-Iranian Relations, 1932-1982 (Al-Saqi, 1993) 50-51.
} 
develop into any amicable or hostile relationships. In fact, these encounters, regardless of nature and outcome, were diluted, sporadic and episodic.

\section{Post-War Context and International Security}

The Western strategic planning for the post-war context granted both Iran and Saudi Arabia an important role to play. In light of the growing geopolitical and economic significance of the region, the Western powers determined that the stability of the region would be guaranteed by ensuring the domestic security in Iran and Saudi Arabia. Below, the presence of the United States in the region and where Iran and Saudi Arabia fit in the post-war order are contextualized.

The historical origin of the United States' interests in the Persian Gulf region is rooted in the developments of the First World War along with the increasing importance of oil as a key economic and strategic commodity for the United States. ${ }^{323}$ The US involvement in the Middle East is best captured by Andrew Bacevich' argument which highlights the two interrelated historical processes that have shaped the United States' global exercise of power. ${ }^{324}$ These processes are a mass consumerist ethos in American culture and a corresponding drive to sustain global military supremacy in order to ensure privileged access to global energy, markets and credit. During the $20^{\text {th }}$ century, Fordist industrial capitalism in the US was setting global standards of dynamism and

\footnotetext{
323 John A. DeNovo, American Interests and Policies in the Middle East, 1900-1939 (Minneapolis: University of Minnesota Press, 1963) 167-69.

324 See Andrew J. Bacevich, The new American militarism: How Americans are seduced by war. (Oxford University Press, 2013); Andrw J. Bacevich, The limits of power: The end of American exceptionalism. (Macmillan, 2008); Andrew J. Bacevich, Washington rules: America's path to permanent war. (Macmillan, 2010).
} 
productivity. ${ }^{325}$ This energy-intensive model required raw material for its pervasive petrochemical industry, and inputs for its increasingly mechanized agriculture. As the result, oil became indispensable to the Fordist capitalism and the twentieth century global order. The significance of oil in shaping the American strategic interests can also be accounted for by the exigencies of the modern era of mechanized warfare. ${ }^{326}$ Therefore, the quest for oil and military supremacy correlated dialectically.

After the Second World War, creating a world which would be hospitable to the growth of US-centered capitalism became as paramount as containing communism. ${ }^{327}$ This meant an inevitable juxtaposition of capitalist "free world," created after the image of the "American way of life," with globally projected US military power. ${ }^{328}$ This foundational vision of global order embodied in NSC-68 (1950, reprinted in May 1993) normatively justified US interventions in order to counter political forces which might inhibit the growth of US-dominated global capitalism and support those forces that are favorable to such a geopolitical project. ${ }^{329}$ The reprint of NSC-68 in 1993 demonstrates that the rationale behind this project far exceeded the exigencies of the grand ideological struggle between the two superpowers.

Insofar as the Fordist global order depended upon ample and cheap supplies of oil, US strategists sought to establish predominance in the oil-rich Persian Gulf region to

325 Mark Rupert, Producing hegemony (Cambridge University Press, 1995).

${ }^{326}$ DeNovo, American Interests, 167-69.

${ }^{327}$ Robert A. Pollard, Economic security and the origins of the Cold War: 1945-1950. (Columbia University Press, 1985).

${ }^{328}$ Andrew J. Bacevich, “The real world war IV”. The Wilson Quarterly (1976-), 29.1 (2005) 36-61.

${ }^{329}$ Stephen Kinzer, Overthrow: America's century of regime change from Hawaii to Iraq. (Macmillan, 2007) 
secure "[an] unhindered flow of oil ...to the world market at a stable price." 330 Pivotal to this strategy was the US relations with Iran and Saudi Arabia. However, the United States was not among the major powers historically having a foothold in the Middle East.

The entrance of the United States in the region was generally facilitated by the positive image of the country in the Middle East between the two wars. Ever since the early days of the republic, the United States had its destiny tied to serving as a beacon of freedom, hope and advancement. Conceiving the values on which the republic was founded as universal moral maxims had the founding fathers think of the United States as a 'shining city on the hill' for others to emulate. Through the isolationist years of the $19^{\text {th }}$ century, such moral maxims did not come to the fore of the US foreign policy in observance of the accepted Westphalian doctrines of sovereignty and non-intervention. In fact, the promotion of such moral virtues was largely a missionary affair than political. An evidence to this observation is John Quincy Adams' famous statement that the United States was only "the well-wisher to the freedom and independence of all" but not a nation that "goes in search of monsters to destroy."

The presidency of Woodrow Wilson was a fundamental break from this pattern. After a century of feeling inhibited by the Westphalian order, the First World War presented an opportunity for Wilson to remake the international order based on the underlying political moral maxims that captured the essence of America. Indeed, Wilson explicitly justified America's involvement as premised on the objective of reordering the international system in its own image. Among the values that guided Wilson's agendum

\footnotetext{
${ }^{330}$ United States, "United States Security Strategy for the Middle East", ed. Department of Defense (GPO, 1995).
} 
was the notion that people had an innate right to determine their own future. These values, specifically in clear tension with long-standing Westphalian notions on a nation's sovereignty over its internal polity, resonated with the Middle Easterners who on top of the centuries-long abuses of colonial powers had to bear with the arrangements that the British and French had established in the region as the result of the 1916 Sykes-Picot Agreement.

Between the wars, Woodrow Wilson's Fourteen Point Proposal was commonly cited by nationalists in their quest for self-determination and as the result America gradually presented itself as a benign alternative to France and Britain. The United States was completely aware of such sentiments in the region and, as the result, acted carefully so not to upset the favorable vision of the US in the region. Between the two wars, the United States clearly refrained from adopting policies that would insinuate semblance of the French or British imperialism, and propagated ideas that most actors in the region found appealing. ${ }^{331}$

Well before World War II drew to a close, the United States began to signal a shift in its approach. During the war, U.S. officials began to articulate a novel conception of the post-war world order and the role that the United States wished to play in that context. Roosevelt had given an early indication of this broad reading of American interests in a letter to Stalin. As he was referring to southeastern Europe where America had traditionally no interest in, Roosevelt wrote, "You, naturally, understand that in this global war there is literally no question, political or military, in which the United States is

\footnotetext{
${ }^{331}$ Philip J. Baram, The Department of State in the Middle East, 1919-1945 (University of Pennsylvania Press, 1978) 56; Also, Mark Gasiorowski, "US foreign policy toward Iran during the Mussadiq era," in David Lesch, The Middle East and the United States, ed. (Boulder, CO: Westview press).
} 
not interested." ${ }^{332}$ Roosevelt made a clearer assertion in March 1944 in his letter to James Landis, Director of Economic Operations in the Middle East. He wrote "the Middle East is an area in which the United States has a vital interest. The maintenance of peace in that area, which has so frequently seen disturbances in the past, is of significance to the world as a whole." 333

The context of the US involvement in the region after 1945 closely followed those early indications. Following the armistice, the Truman administration challenged domestic isolationist sentiments in support of the view that, as the predominant world power, America's interests now stretched around the globe. From this point forward, ensuring the nation's security, Truman administration made clear, would require maintaining military superiority and economic "preponderance." This vision entailed a guarantee of unfettered access to natural resources, skilled labor, and markets, as well as military facilities on a global scale. American officials did not see themselves as pursuing colonial interests nor did the White House consciously seek to establish outright hegemony in international affairs. Instead, the new vision the administration embraced was one of ensuring the conditions necessary for peace and economic prosperity for all nations - conditions that were tightly linked, and seen as fully consistent, with furthering the economic and national security interests of the United States. ${ }^{334}$

\footnotetext{
${ }^{332}$ Quoted in Charles E. Bohlen, Witness to History 1929-1969 (Norton and Company, 1973) 162.

${ }^{333}$ President Roosevelt to James Landis, Memorandum: 800.24/1541, March 6, 1944.

${ }^{334}$ For a thorough analysis of the shaping of postwar American national security policy, see Melvyn P. Leffler, A Preponderance of Power: National Security, The Truman Administration and the Cold War (Stanford University Press, 1992). For an examination of the underlying links between economic and military strength, see Paul M. Kennedy, The Rise and Fall of the Great Powers: Economic Change and Military Conflict from 1500 to 2000 (Vintage Books, 1989).
} 
The Soviets Union with its communist worldview was the principal source of threat to the American novel conception of the peaceful world. A series of events beginning even before the end of the war combined to reinforce Truman administration's suspicion of Kremlin intentions. The West had been concerned about Soviet aims for years, particularly since the signing of the 1939 Nazi-Soviet pact, which had led to attacks on Finland and the occupation of eastern Poland and the Baltics. By the time the Allied leaders met at Yalta in February 1945, the Red Army's brutal sweep across much of Eastern Europe in the wake of Germany's retreat had magnified Western worries over the region's postwar future. By the beginning of 1946, the Truman administration was already under pressure by public opinion and growing Republican criticism for being soft on Soviets when on February 9, Stalin delivered a speech that sounded like a renunciation of the wartime alliance, a reassertion of Marxist-Leninism indicting the imperialist West, and a warning to the Soviet population to prepare themselves for an eventual conflict.

The US global strategic considerations and concerns over Soviets' ambitions found stronger reflection in American foreign policy towards the Persian Gulf region. The reasons why the United States found key strategic interest for the United States during the Cold War era are captured by Michael Hudson in his article "To Play the Hegemon: Fifty Years of US Policy Towards the Middle East." Hudson argues that "the entrenchment of Soviet power" in the Persian Gulf and possible Soviet disruption of oil flow from the region would have caused a "decisive shift in the world balance," and "the economy of the free world," leading to the ultimate "triumph [of the Soviet Union] throughout Asia, Africa, and Europe." 335

\footnotetext{
${ }^{335}$ Michael C. Hudson, "To Play the Hegemon: Fifty Years of US Policy Towards the Middle East",
} Middle East Journal 50.3 (1996): 334. 
In light of these exigencies, Iran and Saudi Arabia found an important place in the United States' strategic thinking; however, the United States was more concerned with Iran than Saudi Arabia in the immediate years after the Second World War through 1955. Between 1946-1955, Soviet-American rivalry was concentrated largely in the non-Arab 'northern tier' of countries bordering the USSR itself, namely Turkey, Iran, and Greece. In this phase of the global contest, the USSR possessed neither the will nor the capacity to challenge the west in the Arab world. ${ }^{336}$

\section{International Security and Where Iran Fit in the United States' Strategic Thinking}

Iran experienced the Cold War as early as 1944, well before the end of the Second World War. This was when the Soviets launched a propaganda campaign against the British and the Americans for their alleged role in persuading Iran to deny the Soviets an oil concession that they were bidding, ${ }^{337}$ while Kremlin was fomenting separatism in northwest Iran. ${ }^{338}$ In a secret letter to President Roosevelt on January 24, 1944, Churchill wrote:

According to the reports received from Azerbaijan, a group of people who are not native inhabitants to the region have launched a campaign with the aim to culturally attach the Iranian Azerbaijan to the Soviet Azerbaijan. Even though there is no information at hand confirming any attempt to annex Iranian Azerbaijan to the Soviet's politically, the possibility that

\footnotetext{
${ }^{336}$ Fred Halliday, The Middle East in international relations: power, politics and ideology. (Cambridge University Press, 2005).

${ }^{337}$ Mostafa Fateh, Panjah Sal Naft e Iran [Fifty Years Iranian Oil] (Tehran: Chehr Publication, 1956) 335; See also Hamidreza Dehghani, "Nazari ba tasire mozou e nafte shoma va afzayesh nofuze amrika dar iran," [A Thought on the Impact of the Caspian Oil Controversy on the Increase of American Influence in Iran] Tarikhe Ravabete Khareji, no. 37 (2008).

${ }^{338}$ J.C. Hurewitz, "Iran in World and Regional Affairs," in Ehsan Yar-Shater, ed. Iran Face the Seventies (New York, Praeger Publishers, 1971) 117.
} 
cultural annexation may serve as a means for political annexation cannot be ignored. ${ }^{339}$

Roosevelt replied to Churchill on January 26 in a letter which reflects, in the hindsight, the limited understanding of the US policymakers of the possible course of events in the aftermath of the WWII. Roosevelt wrote:

I received your letter but I believe it is too early to speculate about the Soviets' future plan in Azerbaijan. I agree with you that those propagating the cultural unity of the two Azerbaijans are directed by the Soviets but I cannot predict if cultural unification leads to any political unification. Even though the Soviets might have plans for their neighboring countries, but they are too entangled in the war to be able to implement those plans. Once the war is over, we will see if they intend to spread their ideology in their neighboring countries. If the Soviets decide to do so, then the United States, in line with its international obligations, will counter that effort. ${ }^{340}$

With that background, Harry S. Truman and his advisers were intent to solidify Iran's anchorage in the Western camp from the earliest days of the Cold War. But, Iran's place rose in importance in the US strategic thinking as the United States became increasingly concerned with the Soviets' probable ambitions in the Middle East. One of the earliest episodes that contributed to the stiffening of American attitudes toward Soviets was the crisis in the northern Iranian province of Azerbaijan. Since August 1941, Soviet and British forces had occupied the northern and southern segments of Iran respectively according to Tripartite Treaty of Alliance with Iran in order to keep the integrity, sovereignty and independence of Iran in face of the German threat. In January 1942, by agreement with Mohammad Reza Pahlavi, the Soviets and British pledged to

\footnotetext{
${ }^{339}$ Churchil's secret letter to Roosevelt, Jan. 24, 1944. Warren F. Kimball, Mokatebat e Churchil and Roosevelt, trans. by Zabihollah Mansouri.

${ }^{340}$ Roosevelt's secret letter to Churchil. Jan, 26, 1944. Warren F. Kimball, Mokatebat e Churchil and Roosevelt, trans. by Zabihollah Mansouri.
} 
withdraw their forces within six months after the end of hostilities. When the March 2, 1946, deadline arrived, the British complied, but Moscow balked, citing threats to Soviet security. $^{341}$

Both Britain and the United States found the Soviet decision alarming but they did not have much leverage over Soviets since they needed the Red Army in Europe, and ultimately in Japan. Iran, with Washington's encouragement, took the issue to the newly founded United Nations while Tehran's Prime Minister, Ahmad Qavam, traveled to Moscow to strike a deal directly with the Kremlin. By early May 1946, Stalin finally decided to remove his forces from Azerbaijan as the Soviets still needed to work with the more powerful Western governments and their wartime agreements (especially Yalta) to advance Soviet international interests. Stalin agreed to pull the Red Army out of Iran in return for the creation of a joint Soviet-Iranian oil company, a guarantee of stability in the northern provinces and a "friendly" attitude by Tehran toward Moscow. These demands were closely tied to both Soviets' traditional imperial aims and their more immediate security concerns. ${ }^{342}$ Ultimately, Moscow left Iran empty-handed because the Iranian parliament never ratified the agreement. ${ }^{343}$ This entire saga led the Truman administration

\footnotetext{
${ }^{341}$ Malcolm Byrne, “The Road to Intervention: Factors Influencing US Policy toward Iran, 1945-1953.” in Mark Gasiorowski and Malcolm Byrne, eds., Mohammad Mosaddeq and the 1953 coup in Iran (Syracuse University Press, 2004), 201-226. The validity of the argument about the existence of security threats posed by Iranians unto Soviet interests is contested; however, in December 1945, Stalin told British Foreign Secretary Ernest Bevin that the Red Army was needed in Azerbaijan to prevent hostile Iranian forces from sabotaging the petroleum industry centered in Baku (Ambassador in the Soviet Union, Harriman, to the acting secretary of state, Dec. 23, 1945, cable 4262, in FRUS, 1945, 8:510-11.; The CIA acknowledged that Moscow had an interest in protecting "its vital Baku oil fields" from outside attacks (See the CIA memorandum for the president on July 27, 1950, file: Iran-US, Relations, Documents, 1950, National Security Archive.

${ }^{342}$ Natalia Yegorova, "Iran Crisis of 1945-1946: A View from the Russian Archive," Cold War International History Project, Woodrow Wilson International Center for Scholars. 18.

${ }^{343}$ See Louise Fawcett, Iran and the Cold War: the Azerbaijan Crisis of 1946 (Cambridge University Press, 1992); Also Ervand Abrahamian, Iran between Two Revolutions, (Princeton University Press, 1982).
} 
to draw very definite conclusions about Soviet general conduct and in relation to Iran specifically. Based on these events, the US concluded that Stalin's conduct in Azerbaijan and Kurdistan, coming on the heels of the Soviet suppression of Eastern Europe, could only be seen as hostile to Western interests and a confirmation that the Kremlin could not be trusted to honor its international commitments.

The recent archival revelations and scholarship show that Moscow's outlook during and after the war mirrored Washington's perceptions in several fundamental ways. Initially, Stalin seems not to have had a consistent postwar strategy. Beyond pursuing certain cherished security aims such as establishing Soviet-dominated regimes in Eastern Europe ${ }^{344}$ he responded to each situation on a case-by-case basis, bringing to bear a mix of motivations deriving from historical Russian objectives, revolutionary ideology, security concerns, economic or material imperatives, power politics, domestic factors, and even personal impulses. All of these strands together formed a pattern of steady, probing expansionism that was opportunistic in the extreme but that also stopped short of deliberately provoking a military confrontation with the West. ${ }^{345}$

As suggested by Kennan's February 1946 "Long Telegram," the mixture of ideological and practical considerations drove Soviets, in Molotov's words, "to expand the borders of [their] Fatherland" as far as possible. ${ }^{346}$ As for the Near East, a typical

\footnotetext{
${ }^{344}$ New evidence indicates that Stalin also had well-developed ideas in other selected areas, such as consolidating the positions of communist parties in Western Europe. See Eduard Mark, "Revolution by Degrees: Stalin's National-Front Strategy for Europe, 1941-1947," Cold War International History Project, Working Paper no. 31, Woodrow Wilson International Center for Scholars, (Washington DC, 2001). 
report from July 1946 states, “The Soviet Union desires to include Greece, Turkey, and Iran in its security zone through the establishment of 'friendly' governments in those countries.” By the end of war, Stalin seemed reasonably satisfied with Soviet territorial gains in all direction except the regions below Caucasus. Since at least the eighteenth century, the tsars had eyed Persia both as a gateway to the Persian Gulf and south Asia and as a barrier to outside, mainly British, interference. ${ }^{347}$ Accordingly, Stalin, as Albert Resis recounts, points to this region on a map and says, "I don't like our border right here." 348

Truman's concerns were reinforced by crises in Turkey and Greece. Along with Iran, these two countries constituted the Northern Tier in U.S. strategy, a first line of defense against communism stretching from the Mediterranean to South Asia. In August 1946, the Soviets demanded military rights to the Dardanelles with Turkey. Coming on the heels of so many other apparently provocative steps, the Kremlin's proposal for joint defense of the straits with Turkey was interpreted in Washington as a hostile move that would not only give the Soviet navy direct access to the Mediterranean through the Black Sea but would also, as Truman later wrote, "in the natural course of events, result in Greece and the whole Near and Middle East falling under Soviet control."349

As the sense of urgency heightened on September 24, 1946, the views of the president and his advisers became more rigid. In late September, a particularly influential

\footnotetext{
${ }^{347}$ See Martin Sicker, The Bear and the Lion: Soviet Imperialism and Iran (New York: Praeger, 1988), 935; also, Peter Hopkirk, The Great Game: The Struggle for Empire in Central Asia (New York: Kodansha International, 1994).

${ }^{348}$ As recounted in Albert Resis, ed. Molotov Remembers: Inside Kremlin Politics, Conversations with Felix Chuev (Chicago: Ivan R. Dec.1993), 8.

${ }^{349}$ Harry S. Truman, H. S. Memoirs by Harry S. Truman: Years of Trial and Hope (Doubleday, 1956) 97.
} 
study known as the Clifford-Elsey report was introduced to the president. This report synthesized the consensus of several senior experts, depicting Soviet international behavior in heavily ideological terms and warning of the need to be prepared to confront the Soviets "vigorously," using, if necessary, the "language of military power ... the only language which disciples of power politics understand." ${ }^{350}$ In the Near East, as in other parts of the world, the Kremlin had been able to "flow into the political vacuum" of the region "because no other nation was both willing and able to prevent it." The Soviet were prepared to "take over new areas in the same way," warned the Clifford -Elsey report.

According to the U.S. intelligence assessments at the time, Moscow was unlikely to risk open war under current conditions but instead would rely on infiltration, cooptation, and subversion in Iran and elsewhere on the "periphery." 351 Therefore, on June 26, 1950, the day after North Korean forces attacked South Korea, President Harry S. Truman was more concerned with the Middle East and more specifically Iran and not necessarily the Far East. ${ }^{352}$ This means that the significance of Iran for Washington had grown beyond the strategic importance of the country on its own right to the point that U.S. officials began to tie the fate of Iran to the rest of the Middle East. Iran, aside from possessing oil reserves of its own, was an important buffer between the USSR and the Persian Gulf and Indian subcontinent. U.S. officials had faith that the Russians had

\footnotetext{
350 "American Relations with the Soviet Union: A Report to the President by the Special Counsel to the President," Sept. 24, 1946, in Arthur Krock, Memoirs: Sixty Years on the Firing Line (New York: Funk and Wagnalls, 1968), 419-482.

${ }^{351}$ See, for example, Central Intelligence Group (CIG), Weekly Summary, "The Azerbaijan Settlement," June 14, 1946; CIG, "Soviet and Foreign Military Policy," ORE 1, July 23, 1946; CIA, Weekly Summary, "Iran," Mar. 18, 1949; and CIA, Special Evaluation no. 39, "Possibility of Soviet Aggression Against Iran," July 27, 1950. These reports are reprinted in Woodrow J. Kuhns, ed. Assessing the Soviet Threat: The Early Cold War Years (Washington DC: Center for the Study of Intelligence, CIA, 1997).

352 Byrne, “The Road to Intervention,” 201-226.
} 
coveted a port on the "warm waters" of the Persian Gulf since Peter the Great. If Moscow gained that access, Western strategists were afraid that it would place the even larger oil fields of the Saudi peninsula, and beyond them British military and commercial interests from Suez to India under direct threat. In this sense, Iran was "vital to the security of the United States" ${ }^{353}$ and the British interests; therefore, neither Washington nor London was prepared to let that happen.

During the immediate postwar period, by mutual agreement with the United States, primary responsibility for defense of the Middle East rested with Britain. This reflected a recognition of long-standing British economic and security interests as much as an awareness of the limitations on the U.S. military's global reach. But Britain's own economic picture was bleak as the crippling effects of the war forced a reevaluation of the country's ability to manage its far-flung assets. In February 1947, the Foreign Office secretly told the US State Department that London would not able to uphold its military and economic commitments to Greece and Turkey for a long time. ${ }^{354}$ This meant that the Truman administration was going to be unassisted in the crucial defense of the Northern Tier.

The enunciation of the Truman Doctrine on March 12, 1947 reflected the United States' readiness to take on the onerous task of filling the void created as of the British gradual withdrawal from the Near East. The Truman doctrine was a broad statement of intent "to support free peoples who [were] resisting attempted subjugation by armed

\footnotetext{
${ }^{353}$ See FRUS, 1947, 5:575. A virtually identical policy statement appears two years later in "Reports of the National Security Council on the Position of the United States with Respect to Iran."

${ }^{354}$ See FRUS, 1947, 5:32-37.
} 
minorities or outside pressures. ${ }^{" 355}$ Despite the seemingly broad scope of the president's address, the Truman Doctrine reflected the more constrained "strong points" strategy as described by Kennan and already in use by the United States at the time. Originally, the concept of containing the Soviet Union had entailed reacting to Kremlin aggression anywhere it appeared. ${ }^{356}$ But U.S. strategists and politicians realized that a "perimeter" defense was both militarily and economically unfeasible. The United States did not possess the resources for an undertaking of that scope, and the domestic political mood was not supportive of militating for expanding obligations overseas so early after the war. Instead, certain areas of the world were identified as being crucial to American interests and deserving of the commitments needed to keep them in the Western camp. For postwar planners, Europe and Japan were the most critical areas because of their enormous industrial and economic potential. They were therefore the focus of the most extensive economic and military restructuring schemes of the period, including the Marshall Plan, expounded in June 1947. Other areas of the world that were mainly rich in strategic resources such as oil, and likely to be targets of the Soviets, formed a second tier of importance. This category included the Near East, comprising Greece, Turkey and Iran, also known as the Northern Tier.

\footnotetext{
${ }^{355}$ For more on the US-Soviet confrontation in the region, see Bruce R. Kuniholm, Origins of the Cold War (Princeton University Press, 2014); For a different perspective on the evolution of the superpower rivalry in the early postwar era, see Leffler, Preponderance of Power, especially on the Near East and Iran, 77-81, $121-127,142-47,237-39,288-91,419-26,476-85$.

${ }^{356}$ Kennan's best-known analyses of Soviet behavior and prescription for US policy were contained in the "Long Telegram," Moscow Embassy telegram 511, Feb. 22, 1946, FRUS, 1946, 6:696-709; and "The Sources of Soviet Conduct," Foreign Affairs 25 (July 1947): 572-76, 580-82. See also the extended discussion in John Lewis Gaddis, Strategies of Containment: a critical appraisal of American national security policy during the Cold War. (Oxford University Press, 1982).
} 


\section{International Security and Where Saudi Arabia Fit in the United States' Strategic Thinking}

The case of Saudi Arabia in the immediate years after the end of the Second World War was different. Unlike Iran that was placed in the Northern Tier, therefore deserving an important place in the American strategic thinking, Saudi Arabia was not subject to direct communist threat until 1955 as the Soviets neither had the capacity nor the willingness to extend their outreach to the Arab world by then. In contradistinction to Iran which was passively dragged into the new world order, Saudi Arabia had to carve itself a place in the American strategic thinking between 1945 through 1955. The fact that Saudi Arabia was not included in the Northern Tier did not mean that Saudi Arabia had no gravitational effect on American policies toward the region. Below, the (re)positioning of Saudi Arabia in the American strategic thinking is discussed.

The overarching reason that explains Washington's gravitation to Saudi Arabia was economic interests. These interests were so vital that they justified cooperation despite domestic backlash in the Congress on the charge that Saudi Arabia embodied a political system that shared none of the American ideals. The Saudi oil, alone, rendered this country indispensable in the post-war world order that the US envisaged, the context of which has been laid out above. The United States' intensified involvement in Saudi Arabia could be traced back to the 1930s when Standard Oil of California (SoCal) discovered commercial quantities of oil on the eastern shores of Saudi Arabia. When SoCal won the concession in 1933 to explore oil resources in Saudi Arabia, it invited 
Texaco and then later Exxon and Mobil to become partners in newly established Saudi oil company, ARAMCO. ${ }^{357}$

The importance of Saudi Arabia for the energy-intensive Fordist industrial capitalism was so high that Franklin D. Roosevelt pronounced the defense of Saudi Arabia among the US national interests, long before any hint of energy shortage. ${ }^{358}$ To solidify this intention. Roosevelt established a strategic partnership with Saudi ruling family in 1945 by forging "an agreement with Abdul-Aziz ibn Saud, the founder of modern Saudi dynasty, to protect the royal family against its internal and external enemies in return for privileged access to oil." 359

During the Second World War, Axis powers' threat to the Allies' oil supplies and transportation lines dramatically impacted the production of Saudi oil and revenues. The drop in oil revenues was compounded by a sharp decrease in pilgrimage revenues, causing a financial crisis in Saudi Arabia. In response, Abdul Aziz asked SoCal for a loan and threatened to cancel the concession if his request was not honored. ${ }^{360}$ In hindsight, it is obvious that Abdul Aziz was trying to take advantage of the rivalry between the great powers in the region, especially Britain and the United States. The US strategists were savvy enough to understand that Saudi Arabia's financial crisis had to be handled right or it would have had catastrophic repercussions. The financial crisis could have swayed

\footnotetext{
${ }^{357}$ Anthony Sampson, The seven sisters: the great oil companies and the world they shaped. (Bantam, 1991); See also Simon Bromley, American Hegemony and World Oil, (Cambridge: Polity Press, 1991); Daniel Yergin, The Prize: the Epic Quest for Oil, Money and Power, (London: Simon and Schuster, 1993).

${ }^{358}$ David Holden \& Richard Johns, The house of Saud. (Sidgwick \& Jackson, 1981) 128; See also Alexi Vassiliev, The History of Saudi Arabia. (Al-Saqi, 2013) 325

${ }^{359}$ Michael Klare, "Bush-Cheney energy strategy: Procuring the rest of the world's oil." Foreign Policy in Focus, 1.13 (2004) 1-10.

${ }^{360}$ Vassiliev, The History of Saudi Arabia. 323-324.
} 
Saudis toward the Axis powers had they outmaneuvered Allies to provide financial support to Saudis. Not only would this jeopardize American interests, but Saudis' move toward the Axis powers could have impacted the fate of the war, considering the weight of Saudi Arabia in both Islamic and Arab world.

SoCal turned to the US Government for help. President Roosevelt initially vacillated whether the United States, Britain, or a joint venture should take on the task of assisting Saudi Arabia. ${ }^{361}$ The representatives of American oil companies in Saudi Arabia adamantly urged the US Government to support King Abdul Aziz as a strong and true friend of the Allies. These representatives warned that the British possible provision of a substantial loan to the Saudis would strengthen their position in Saudi Arabia which would threaten American oil interests. ${ }^{362}$ SoCal representatives asked their government to provide direct aid to Saudi Arabia and suggested that the Kingdom should be included in the Lend-Lease Act. As a result, in February 1943, Roosevelt took the initiative and instructed his government to include Saudi Arabia in the Lend-Lease aid program at an estimated cost of $\$ 99$ million. This enabled the American oil companies to have the upper hand over their British competitors. ${ }^{363}$ Harold Ickes, the US Secretary of Interior, perfectly captures this rivalry when he acknowledged that "When one turns to the question of who the Saudi concession should be protected against, it is surprising to find that the perceived enemy was Great Britain and the British-controlled companies." 364

\footnotetext{
361 ibid.

362 Ernest L. Woodward, British foreign policy in the Second World War. (HM Stationery Office, 1962) 396-397.

${ }^{363}$ See Robert O. Keohane, "State power and industry influence: American foreign oil policy in the 1940s," International Organization, vol. 36, 1 (1982) 165-183.

${ }^{364}$ Lawrence P. Frank, “The First Oil Regime.” World politics, 37.4 (1985) 591.
} 
With the discovery of more oil fields, Abdul Aziz better appreciated the importance of Saudis' sovereignty over such massive strategic wealth, and how fungible to other sources of power this wealth could be. When the United States began to import oil directly, owing to the shrinkage of domestic oil production and a substantial growth in demands, ${ }^{365}$ Abdul Aziz perceived the American interests in the region as an opportunity for Saudi Arabia. Undoubtedly, the ever-increasing importance of Saudi oil for the American economy led to a fundamental change in the United States' policy towards Saudi Arabia. ${ }^{366}$ This implied a decision by the United States Government to end the British political supremacy in the region. ${ }^{367}$ By the early 1940s, America had become seriously interested in Saudi Arabia and started to forge political links with it. The American-Saudi link was solidified by the historical meeting between King Abdul Aziz and Franklin D. Roosevelt after the Yalta Conference on February 14, 1945 onboard USS Quincy in the Bitter Lakes of the Suez Canal. ${ }^{368}$ This meeting constituted a great step towards establishing a strong and stable Saudi-American relationship, which has lasted to the present day.

Abdul Aziz enthusiastically desired continued American involvement in the region which could mean more American aid and contribution to the development of Saudi Arabia. Much to the King's satisfaction, there were reasons other than oil to keep Americans interested in Saudi Arabia. During the Second World War, the United States realized that Saudi Arabia could help bridge the two remote fronts in Europe and the

\footnotetext{
${ }^{365}$ Keohane, "State power and industry influence,"168.

${ }^{366}$ ibid.

${ }^{367}$ Woodward, British foreign policy, 399-400.

${ }^{368}$ Harry St. John Philby, Saudi Arabia. (Ernest Benn, 1955) 338.
} 
Pacific where American forces were deployed. Therefore, during their summit, President Roosevelt asked for King Abdul Aziz's permission to use the Saudi's eastern ports and for the establishment of an air force base in the Eastern Province. ${ }^{369}$ King Abdul Aziz agree in principle to the request by the US president. With Germany's deteriorating position, the United States needed to move some of the deployed forces in Europe to the Far East against Japan. Thus, the United States requested to obtain a lease for an air force base in Saudi Arabia pursuant of the exchanges between President Roosevelt and King Abdul Aziz on board of the USS Quincy. This meant the possibility of further entrenchment of American involvement in the region, which was of strategic importance for Abdul Aziz. Since this was an opportunity that Saudi Arabia could not pass up, Abdul Aziz honored the request and authorized in May 1945 the building of al-Dhahran airport. ${ }^{370}$

The strategic importance of Dhahran airfield was clear to the American officials. J. Rives Childs writes, "[without any] knowledge of air or defense strategy[,] one glance at a map [would be] sufficient to persuade [one] of the prime importance of Dhahran, situated on a land mass resembling a gigantic aircraft carrier, astride the Middle East, and close to one of the world's richest oil fields, in which [America] had a controlling interest." ${ }^{371}$ According to the agreement reached by the two sides, the United States committed to return to Saudi Arabia the airport including all the constructions and equipment in it as soon as the Second World War was over. The war ended before the

\footnotetext{
${ }^{369}$ Vassiliev, The History of Saudi Arabia. 326-327.

370 ibid. 327.

${ }^{371}$ James Rives Childs, Foreign Service Farewell, My Years in the Near East. (Charlottesville, 1969) 146; See also James L. Gormly, "Keeping the Door Open in Saudi Arabia: The United States and the Dhahran Airfield, 1945-46." Diplomatic History 4, 2 (1980): 189-206.
} 
construction of the airfield was over, nevertheless, the Saudi government extended the lease several times according to renewed negotiations and revised agreements that would ensure Saudi sovereignty and full authority inside and outside the airport.

After its completion in 1946, the Dhahran airport continued to play an important role in the US military strategy. The Dhahran airport was among the 109 overseas airfields capable of handling American long and medium-range bombers, including the B-36. ${ }^{372}$ The costly maintenance of the lease even after the Japanese surrender triggered a backlash in the US Congress but the significance of Dhahran airfield as a potentially useful second-strike base from which the United States could contain the Soviet Union justified the renewal of the lease, what King Abdul Aziz found highly desirable. ${ }^{373}$ US Ambassador Raymond Hare who was sent to Saudi Arabia mainly to negotiate the Dhahran airfield recalls that "Dhahran airfield was particularly important as a staging point in the event there was trouble with the Russians." ${ }^{374}$ Dhahran contributed greatly to America's continued presence in the region as well as solidifying Saudi-American relations.

Saudi Arabia needed the United States to protect the Al-Saud regime and provide the kingdom with the means necessary for the survival of Al-Saud rule and sovereignty over the largest political entity on the Arabian Peninsula. King Abdul Aziz was apprehensive of the ambitions of Hashemite thrones in Iraq and Transjordan as a potential threat. This apprehension was intensified by King Abdul Aziz's growing

\footnotetext{
372 Gormly, "Keeping the Door Open," 203.

373 Aaron D. Miller, Search for Security: Saudi Arabian Oil and American Foreign Policy, 1939-1949. (Chapel Hill: University of North Carolina Press. 1980) 138.

${ }^{374}$ Paul Aarts \& Gerd Nonneman, Saudi Arabia in the balance: Political economy, society, foreign affairs.
} (NYU Press, 2005) 378. 
skepticism of the British assistance to the Hashemite kings of Iraq and Transjordan, and to a lesser extent, Saudis' regional rival, Iran. ${ }^{375}$ On various occasions, King Abdul Aziz expressed his concerns to the Americans about potential Hashemite attacks, and the British reluctance to restrain the Hashemites' ambitions. During an official visit to the United States in 1947, Prince Saud requested Americans on behalf of his father to extend their support to Saudi Arabia in response to Britain's support of the Hashemites and other regional opponents. ${ }^{376}$ Abdul Aziz believed that only the United States could guarantee Saudi Arabia's security against these threats. ${ }^{377}$ The policy of tying Saudi's security to the American interests in Saudi Arabia yielded Abdul Aziz's desired outcome when Secretary of State, James Byrnes, confirmed to Prince Saud America's full support for Saudi Arabia's territorial integrity and political sovereignty against any external threat. By playing into the discourse of the time and citing the communist threat, Saudi Arabia convinced the United States to aid Saudi Arabia militarily. This included the American involvement in training the Saudi officers, and furnishing Saudi forces with modern American weapons. ${ }^{378}$ These developments were extremely desirable for King Abdul Aziz. The Saudi King was committed to replacing the tribal and quasi-military forces of the Kingdom with a prestigious modern army symbolizing the sovereignty of

\footnotetext{
${ }^{375}$ Vassiliev, The History of Saudi Arabia. 330.

${ }^{376}$ Khayruddin Al-Zirikli, Shibh Al-Jazeerah fi `Ahd al-Malik Abdulaziz. [The Peninsula in the Era of King abdul Aziz] (Beirut: Dar al- 'Ilm li al-Malayeen. 1977) quoted in Mohammad Zaid Al-Kahtani, The Foreign Policy of King Abdul Aziz (1927-1953): A Study in the International Relations of an Emerging State (Diss.).

${ }^{377}$ Leslie McLoughlin, Ibn Saud: founder of a kingdom. (Springer, 1993) 181.

${ }^{378}$ Vassiliev, The History of Saudi Arabia. 342.
} 
the infantile state. The Saudi-American agreements made possible long strides in this direction.

After contextualizing Saudi-Iranian post-WWII relations, below the occasions of Iranian-Saudi encounters and missed opportunities are examined. As a reminder, the argument is that these encounters, regardless of nature and outcome, were diluted, sporadic and episodic.

\section{Iranian Recognition of Israel}

Before the end of the Second World War, Abdul Aziz was among the most influential Arab leaders to the extent that President Roosevelt felt obliged to obtain his support of the settlement in Palestine of the Jewish refugees from Germany and Eastern Europe. President Roosevelt believed that Abdul Aziz had the clout needed to facilitate the Zionist bids. ${ }^{379}$ Roosevelt attempted to make the case for the Zionist movement before the Saudi King; however, Abdul Aziz decisively negated Roosevelt arguments. King Abdul Aziz's replied, "If the Jews are to be compensated for the outrages perpetrated against them, then it should be the perpetrators who carry the cost. If the United States and its allies wished to see the Jews settled on land of their own, then it should be German land that is appropriated." Upon the question of partitioning Palestine, Abdul Aziz uncompromisingly asserted, "Why should the Palestinians be expected to

\footnotetext{
${ }^{379}$ Holden \& Johns The house of Saud. 133; also see David A. Howarth, The desert king: Ibn Saud and his Arabia. (McGraw-Hill, 1964) 203.
} 
atone for the sins of the Germans? Why should the United States look to its friends rather than to its enemies to make reparations for the crimes of its enemies?"380

President Roosevelt was impressed by Abdul Aziz, the clarity of his argument and his determination on the issue of Palestine. ${ }^{381}$ During the Summit meeting, the President Roosevelt pledged not to assist the Jews against the Arabs, and made a promise to consult with both Arab and Jewish sides before making any decision. Shortly before his death on April 12, 1945, President Roosevelt confirmed these verbal assurances in a letter to King Abdul Aziz. In this letter, Roosevelt committed that he would take no hostile action hostile against Arabs. ${ }^{382}$

Roosevelt's successor, Harry Truman, broke the commitment that Roosevelt, as the United States Commander in Chief, had given to Abdul Aziz. ${ }^{383}$ President Truman was sympathetic to the Jewish cause for pragmatist purposes. In November 1945, Truman summoned his Ambassadors in the Arab countries to Washington, and annulled his predecessor's promises with the words "I'm sorry, gentlemen, but I have to answer to hundreds of thousands of people who are anxious for the success of Zionism; I do not have hundreds of thousands of Arabs among my constituents." ${ }^{384}$ King Abdul Aziz tried to counter this ominous course of events by insisting on the pledge the United States had made during Roosevelt's administration. He also emphatically asserted that the Arabs were determined to resist the Jewish state and it could only be established and maintained

\footnotetext{
${ }^{380}$ Howarth, The desert king, 206-207.

${ }^{381}$ Holden \& Johns, The house of Saud. 137.

382 ibid. 138; also see Howarth, The desert king. 206-207.

${ }^{383}$ Holden \& Johns, The house of Saud; Howarth, The desert king, 207.

${ }^{384}$ Holden \& Johns, The house of Saud. 142; Howarth, The desert king, 207.
} 
by force. He insisted that the only acceptable solution to the Palestine dispute was handing the country to its rightful Arab owners and that any other solution would constitute an inhumane aggression. ${ }^{385}$ Abdul Aziz was unsuccessful to turn the tides, and eventually, Truman officially endorsed the partition of Palestine and supported this policy at the United Nations in 1947.386

The creation of Israel entailed some strategic potentials for Iran. The creation of a non-Arab, yet pro-Western state in the region, especially with the specificities of Israel's creation, could give Iran an edge over the rival Arab states. Israel would have Arabs rechannel their attention and resources to deal with such an emergence, a desirable outcome on its own right for the Iranian government. ${ }^{387}$ Iran withheld the recognition of Israel due to Israelis' initial effort to cultivate ties with the Soviets but when Tel Aviv's pro-Western leanings became clear, Mosaddeq government extended de facto recognition to the Jewish state in $1951 .^{388}$ The possibility of close ties with Iran was appealing to Israel as it found itself surrounded by hostile Arab states. The remedy to this geographical imperative was reaching out to the non-Arab states of the peripheral region. This perception predicated Ben-Gurion's doctrine which suggested the necessity of building ties and alliances with state and non-state actors such as Iran, Turkey, Ethiopia, Kurds and the Lebanese Christians. ${ }^{389}$ Iran shared some of the Israelis' concerns regarding the threat of radical pro-

\footnotetext{
${ }^{385}$ Vassiliev, The History of Saudi Arabia. 343.

${ }^{386}$ Holden \& Johns, The house of Saud. 143.

387 Trita Parsi, Treacherous alliance: the secret dealings of Israel, Iran, and the United States. (Yale University Press, 2007) 20.

388 Rouhollah K. Ramazani, "Iran and the Arab-Israeli Conflict," Middle East Journal 3 (1978):414 415; Also, Sohrab Sobhani, The Pragmatic Entente: Israeli-Iranian Relations, 1948 -1988 (New York: Praeger, 1989), 23.

${ }^{389}$ Sobhani, the Pragmatic Entente, 34.
} 
Soviet Arab states and the pan-Arabism propagated by the Anti-Western regime of Nasser in Egypt. Nasser's anti-colonial and socialist rhetoric was gaining strong traction in the Arab world; therefore, neither Israel nor Iran could overlook that. ${ }^{390}$ Another viable explanation regarding the urge on the Iranian side for establishing ties with Israel would be the pragmatist objective of solidifying relations with the United States in light of the capacity that the Jewish population demonstrated by impacting American politics beginning with the election of President Truman.

The de facto recognition that Iran granted Israel troubled the Arab states the region including Saudi Arabia and King Abdul Aziz whose strong take on the matter was wellknown. What compounded the ideological grievance that Saudis had against that recognition, Riyadh was concerned with the implications of Iranian-Israeli ties specifically in the military domain. Despite these grievances, it is interesting that Riyadh did not confront Iran on that matter. While denying recognition to Israel, Abd al-Aziz decided to adopt a policy of "quiet restraint." ${ }^{\text {" }} 391$ King Abdul Aziz was not willing to take on any unnecessary challenge which would alienate the United State and deprive Saudi Arabia from American aid and contribution. Even though King Abdul Aziz had to face strong proPalestinian sentiments not only on the Arab streets but also within the royal family, he considered any policy that would jeopardize the American-Saudi ties illogical. These calculations secured the newly reestablished Iranian-Saudi diplomatic relations as well, and nothing came out of the possibility of an encounter over the divergence of policies toward Israel.

\footnotetext{
${ }^{390}$ ibid. 18.

${ }^{391}$ Banafsheh Keynoush, Saudi Arabia and Iran: Friends or Foes? (Springer, 2016) 64.
} 


\section{Nationalization of Oil and 1953 CIA Coup in Iran}

While Iran was officially in the pro-American camp, its unstable domestic politics threatened to undermine the Shah's commitment to the west. The Shah's position was challenged both by the nationalist forces of the National Front, led by Mohammad Mosaddeq, and by the pro-Soviet Tudeh party.

Ever since 1908 discovery of a large oil field, Iran conceded the right to exploit oil to the Anglo-Iranian Oil Company (AIOC) ${ }^{392}$ in return for only a pittance of the oil export profits. The Iranian middle class and intelligentsia blamed Britain and its imperialist policies for the country's underdevelopment. ${ }^{393}$ Given these sentiments, in March 1951, Iran's Parliament voted to expropriate the oil industry and oust AIOC from Iran. The British responded by placing an embargo on Iranian oil from 1951 to 1953 which caused serious financial hardship for Iran.

When Mohammad Mosaddeq was elected Prime Minister in April 1951, his bid to change Iran's contract with AIOC received support by the sympathetic Truman administration. Washington believed that the popularity of Mosaddeq could provide an alternative to the socialist Tudeh Party. ${ }^{394}$ This support, however, did not carry over to the next administration. Once Dwight Eisenhower was elected president, the United States ceased to demonstrate the same level of patience with Mosaddeq's bargain with

\footnotetext{
392 The company was named Anglo Persian Oil Company between 1908 and 1935. In 1954, the company changed name to British Petroleum Company which is one of the antecedents of the modern BP Public Limited Company.

${ }^{393}$ Yaqub Halabi, US Foreign Policy in the Middle East: From Crisis to Change. (Ashgate Publishing, Ltd. 2009) 33.

${ }^{394}$ Mark Gasiorowski, "US foreign policy toward Iran," 55.
} 
the West in the height of the Cold War. The Eisenhower administration feared that severe economic condition in Iran caused by embargo could drive the whole country into the Soviet sphere of influence. Furthermore, the US began to fear possible ties between Mosaddeq, the clergy and the Tudeh Party, believing that such ties could spur a collusion to counter Western influence in Iran. ${ }^{395}$ With the strengthening of such a perception, the Eisenhower administration joined the British-led conspiracy to overthrow Mosaddeq's democratically elected government. Even though the Eisenhower administration did not view Mosaddeq as a communist, the State Department and CIA had come to believe that Iran was ripe for a communist takeover and as the result Mosaddeq's government had to be toppled. ${ }^{396}$ Kermit Roosevelt, ${ }^{397}$ the mastermind of CIA operations in Tehran, who had been plotting Mosaddeq's overthrow for months operationalized the plot to pave the way for the return of the Shah. Once the Shah returned to Iran he declared, "I regained my throne thanks to God, the Iranian people and the CIA."398

August 1953 was a decisive moment in Iranian politics and in Iran's relation to the Cold War. The opposition bloc of nationalist and communist forces was destroyed, and power came increasingly to be held by the Shah. In 1953, Iran and the US consolidated their strategic relationship which lasted until the revolution of 1979. The coup also led to a reorganization of Iran's oil industry, with US firms now acquiring a 40

\footnotetext{
395 Ashley E. Bayne, “Crisis of confidence in Iran.” Foreign Affairs, 29.4 (1951) 578-590.

${ }^{396}$ Halabi, US Foreign Policy in the Middle East, 34.

${ }^{397}$ Kermit Roosevelt Jr. (February 16, 1916 - June 8, 2000), a grandson of U.S. president Theodore Roosevelt, was a Harvard-educated career intelligence officer who served in the Office of Strategic Services, forerunner to the Central Intelligence Agency (CIA), during and following WWII.

${ }^{398}$ Halabi, US Foreign Policy in the Middle East, 35.
} 
percent share of total output in a new consortium, therefore, technically, the nationalization of 1951 was not reversed.

Surprisingly, Iranian-Saudi relations remained untroubled in these tumultuous years. During the early 1950s leading up to the Shah's fleeing from Iran in March 1951, not to return until August 1953, Saudis refrained from adopting any provocative policy toward Iran, even though the time might have been right for Saudis' further regional assertion. There is hardly any document from this period that suggests Abdul Aziz's concern with Saudi Arabia's regional rival, Iran. Instead, the Saudi ruler was more preoccupied with Britain than any other real or perceived threat in this period. The Buraimi crisis is a clear indication of where King Abdul Aziz's real concerns rested.

The villages of Buraimi Oasis were disputed territories sitting on a large swath of unchartered oil deposits. Abdul Aziz was aware of the importance of sovereignty over this undemarcated land which was disputed among several claimants. Emboldened by his putative oil holdings, on September 17, 1952, Abdul Aziz invoked a previously declared American commitment to "preserve the independence and territorial integrity" of Saudi Arabia, but not against Egypt, Iraq, Yemen, Iran or even the Soviet Union, but rather this was a call on the United States to defend Saudi Arabia against Britain, the Washington's closest ally. In yet another attempt, in May 1953, King Abdul Aziz requested the American assistance against Britain in the Buraimi dispute, ${ }^{399}$ erroneously thinking that the United States would forgo the Cold War strategic contingencies for the interests of the American oil companies. The United States clearly did not want to jeopardize its

\footnotetext{
399 Prince Faisal's visit to the Department of State, Memo of Conversation, US Department of State, Washington. 3 March, 1953.
} 
alliance with Britain over a land dispute. In a delayed response, American government encouraged both sides to practice quiet diplomacy in order to settle their differences. In May 1953, during his visit to Riyadh, the US Secretary of State, John Foster Dulles made it clear to Saudi officials that the United States would not appreciate Saudis' compromising American policies by bringing up local and regional disputes. ${ }^{400}$ Regardless of the outcome of the dispute and what Saudi Arabia could harvest from an attempt to raise the bars of an alliance with the United States, the Buraimi crisis indicates where Abdul Aziz's primal security concerns rested in his final years of reign and life. ${ }^{401}$ Another explanation as to why Saudis refrained from any provocative policy toward Iran during these years need to be sought in the way these developments were perceived and received in Saudi Arabia. Iran's oil nationalization inspired identical calls to end oil concessions to Western corporations in other countries such as Bahrain and Iraq. ${ }^{402}$ In Saudi Arabia, officials putatively praised Mosaddeq's efforts. Iran's vicegerent in Jeddah, Mozafar Alam, reported that during his hours-long dinner with Prince Faisal which almost exclusively focused on Iran's oil nationalization, the Saudi prince spoke highly of Mosaddeq and the National Front. The ulama in Mecca and Medina took an extra step and on a separate occasion told Alam that their prayers were with Mosaddeq. In 1952, the kingdom expanded trade ties with Iran despite the boycotts, and in April 1953, it concluded a one-year commercial agreement, subject to subsequent renewal, to facilitate trade between Iranians and Saudis. As explained, during these years, Saudis

\footnotetext{
${ }^{400}$ David E. Long, The United States and Saudi Arabia: Ambivalent Allies, vol. 3 (Westview Press, 1985) 108-112.

401 J. E. Peterson, "Britain and The Oman War: An Arabian entanglement." Asian Affairs, 7.3 (1976) 285298.

402 Keynoush, Saudi Arabia and Iran, 61.
} 
were fighting a quite similar battle with the British. Arguably, the coincidental alignment of anti-British policies in this period contributed as a secondary factor dissuading adventurous Saudi policies toward Iran.

There is another factor that may explain why the Arabs and more specifically Saudi Arabia did not conduct any anti-Iranian opportunistic policies. This had to do with the recognition of Israel by Iran in 1950. Even though Iran's initial recognition of Israel was only meant to preserve the rights of Iranian citizens inhabiting in that region and any de jure recognition in face of home-grown pro-Palestinian sentiments was impossible, there are signs that the two countries moved to deepen their relations in the mid-1950s. This was concerning for the Arabs in the region; however, due to the growth in power of the Mosaddeq's National Front — which was adamantly against the recognition and contending that it was attained through bribery — and the important role of Ayatollah Kashani, the policy of enhancing ties with Israel got derailed. With growing pressures by the religious hubs in the region including Baghdad and al-Azhar, Iran closed down its Jerusalem consulate. It appears that closing the consulate was, on the one hand, a gesture to empathize with Muslims in the region and regain the confidence of the religious groups. On the other hand, this gesture could have garnered the support of the Arab states in the region for Iran's legal dispute with the Great Britain. Neither of such desired outcomes lasted long enough as with the overthrow of Mosaddeq's government, everything reverted back to where it was prior the departure of Shah from Iran. Nevertheless, the assumption that the closure of the Iranian consulate in Jerusalem meant 
rescinding the 1950 de facto recognition was enough for Arabs to forgo the seizure of opportunities in Iran. ${ }^{403}$

\section{3 - The Succession of King Saud and Disarray in Saudi Foreign Policy}

In 1953, the same year that Mohammad Reza Shah was reinstated by CIA-led coup, Abdul Aziz, the founding father of the Kingdom of Saudi Arabia died and his eldest son, King Saud ibn Abdul Aziz ascended to the throne. King Saud ruled Saudi Arabia during one of the most tumultuous periods (1953-1964) in the history of the country. In this period, the ruling family experienced a sharp division of power between King Saud and his Heir Apparent Faisal which escalated into a bitter feud over political and policy differences. ${ }^{404}$ The bitterness of this feud negatively impacted Saudi Arabia's foreign policy in this period, marked by disarray in foreign policy making, confusion and reversals.

The succession of Saud was smooth, but troubles began within a few years into his rule when real differences between Saud and Faisal surfaced. These differences created irreparable schism in the ruling family. Saud and Faisal disagreed on appointments which constitute a crucial aspect of state-building in any nascent political system. King Saud tended to strengthen his power base within the family, while Faisal concentrated his efforts in the Council of Ministers. Saud appointed his young and inexperienced sons as commander of both National and Royal guards, chief of the Diwan, minister of defense, and governor of Riyadh. This was both concerning and embarrassing

\footnotetext{
${ }^{403}$ See Masoud Koohestaninejad, "ravabeteh iran va Israel dar doreye dolate dr. mosaddegh" [IranianIsraeli Relations During Dr. Mosaddeq's Administration] Tarikhe Ravabete Khareji, no. 15 (2003).

${ }^{404}$ For a detailed assessment of Saud's rule, see Gary Samore, "The Persian Gulf," in David A. Deese and Joseph S. Nye, eds., Energy and Security (Cambridge: Ballinger Publishing Company, 1981) 74-229. See also Vassiliev, The History of Saudi Arabia, 354-368.
} 
to many senior members of the ruling family. ${ }^{405}$ On the other hand, Faisal did not limit the opportunities to his sons, rather he extended them to his half-brothers as well. The deterioration of the Kingdom's finances amidst charges of corruption and extravagance ${ }^{406}$ compounded by the rise of Gamal Abdel Nasser on a wave of Arab socialist ideology which was an unprecedented threat to the conservative Saudi establishment ${ }^{407}$ eventually broke down the unstable state of disunity in Saudi royal family by the early 1958.

The anxiety of King Saud's possible intention to break form the tradition and instead transfer power to one of his sons was exacerbated by the king's excessive expenditure habits amidst deteriorating fiscal health of the monarchy. Therefore, senior members of the royal family urged King Saud to relinquish power to Faisal. Facing the pressure, King Saud transferred executive powers to Faisal by a royal decree on March 24, 1958. Faisal rectified the fiscal situation, reduced the royal family expenditures, made the appointments to the Council of Ministers methodically, and personally took over the Ministries of Foreign Affairs, Interior, Commerce and Finance. ${ }^{408}$ Faisal's success in turning the tides in both financial and foreign policy realms encouraged King Saud to reclaim full power. With the support of tribal and commercial circles and a disgruntled faction of younger princes, by late 1960s, King Saud reshuffled the council of Ministers by appointing himself prime minister and replacing some of the cabinet officials with his sons and the supportive "free princes.” In response, Faisal and Council of Ministers

\footnotetext{
405 Joseph Kechichian, ed. Succession in Saudi Arabia. (Springer, 2001) 41.

${ }^{406}$ Helen Lackner, A House Built on Sand: A Political Economy of Saudi Arabia, (London: Ithaca Press, 1978) 57-68.

${ }^{407}$ William Powell, Saudi Arabia and Its Royal Family (New Jersey: Lyle Stuart, Inc., 1982) 230-232.

408 See Sara Izraeli, The Remaking of Saudi Arabia: The Struggle between King Sa'ud and Crown Prince Faysal, 1953-1962 (Syracuse University Press, 1997).
} 
resigned, and this resignation ushered in a complex period of royal family politics. In the ensuing months, King Saud strengthened the power and position of his sons, especially Minister of Defense Muhammad, who was being discussed as a possible successor.

At the height of his power, however, Saud's health deteriorated, and in December 1961, the monarch sought medical care in the United States. This marked the beginning of Faisal's return to power. Although several Al Saud family members urged Faisal to take control of the government and the country, the Heir Apparent declined, citing a promise he had made to his father to support Saud, even though later he broke the promise. Instead of an outright overtake, Faisal became prime minister, named Khalid deputy prime minister, and formed a new government. He took command of the armed forces and quickly restored their loyalty and morale. This step proved to be a turning point, as later developments proved. ${ }^{409}$

About the same time that Faisal was effectively in charge, civil war broke out in Yemen, and Egyptian forces arrived to support revolutionary elements there against Saudi-supported royalists. Faisal sized the crisis as an opportunity to secure and strengthen his authority by appointing a new Council of Ministers composed of loyal princes. ${ }^{410}$ Among Faisal's loyal supporters, Khalid, the Deputy Prime Minister, was outstanding. Khalid's ties to Jiluwi tribe could undercut Saud's traditional power base. In 1963, Faisal replaced King Saud's sons with new appointees as commander of the

\footnotetext{
${ }^{409}$ See Gerald De Gaury, Faisal: King of Saudi Arabia, (New York: Frederick A. Praeger Publishers, 1967) 93-94.

${ }^{410}$ See Izraeli, The Remaking of Saudi Arabia.
} 
National Guard and the governor of Riyadh. ${ }^{411}$ In 1964, King Saud, however, made one last effort to reclaim his position by ordering the restoration of all his executive powers. In response, Faisal invited leading religious figures and princes to convene in Riyadh in order to find a settlement to persistent feud. At the same time, he cut off King Saud's access to military force by arresting Saud's son Sultan bin Saud, commander of the Royal Guard, among others.

On March 26, a delegation composed of religious leaders met with King Saud and demanded that the King attach the Royal Guard to the Armed Forces, attach the monarch's personal guards to the Ministry of Interior, abolish the Royal Diwan, and rechannel excessive royal expenses to development projects. ${ }^{412}$ King Saud rejected the demands and immediately mobilized the Royal Guard around the palace. What followed was a classic coup because Defense Minister Sultan and National Guard Commander Abdallah had surrounded both the palace as well as the Royal Guard. Even though King Saud's traditional sources of support disappointed him and even the Royal Guard declared allegiance to the Heir Apparent, the king refused to abdicate. On November 2, 1964, the Council of Ministers, under Deputy Prime Minister Khalid bin Abdul Aziz, "asked the Kingdom's Ulama to examine the October 28, 1964 letter from the ruling family—deposing King Saud and proclaiming Faisal monarch—from a canonical point of view, and to issue a suitable fatwa." ${ }^{413}$ A fatwa confirming the latter was issued on the

\footnotetext{
${ }^{411}$ De Gaury, Faisal, 100.

${ }^{412}$ Gary Samore, "The Persian Gulf," in David A. Deese and Joseph S. Nye (eds.), Energy and Security, (Cambridge: Ballinger Publishing Company, 1981).

413 ibid, 194-195.
} 
same day, and Faisal immediately became King, and Saud, along with some of his sons, went into exile.

In this tumultuous period, Saudi foreign policy positions fluctuated with the back and forth changes in the political balance. Series of blunders by King Saud in the realm of foreign policy specifically toward Iraq, Jordan, Syria, Egypt and the United States further separated the king from his Heir Apparent. Among King Saud's novelties in this realm were lukewarm attitude toward the United States, favoring rapprochement with the Hashemite monarchy in Jordan, and aligning with Egypt as Nasser was mobilizing Arab masses for Arab ideals. When Faisal was granted the executive power in 1958, he turned around these misjudgments and revived the conservative approach of Abdul Aziz in foreign policy-making. These fluctuations as well as severe factionalism within the ruling family deterred Saudi Arabia from developing a strong stance on Iran in light of the exigencies of this period. What is documented from this period of relationships between the two states suggests ambivalence or, at best, a hesitant approach. The encounters of the governments in Tehran and Riyadh around the problematique of 1955 Baghdad Pact and 1956 Suez Canal Crisis and the Sinai War attest to this claim.

\section{5 - The Problematique of the Baghdad Pact}

With the return of Mohammad Reza Shah to Iran after the 1953 CIA-led coup and the succession of King Saud ibn Abdul Aziz to the throne as the eldest son of the founder of modern Saudi Arabia, the relations between the two countries entered a new era. Shah demonstrated positive intentions by sending King Saud and his Heir Apparent Crown 
Prince Faisal a Pahlavi Order and a Crown Order respectively. Iranian king also expressed an interest to extend ties with the Saudi Kingdom. ${ }^{414}$

In May 1955, the United States launched the Baghdad Pact to connect the US geographic spheres of influence in the Middle East. The short-lived and "ill-fated" 415 Baghdad Pact was a pro-Western mutual security alliance ${ }^{416}$ suggested by the US Secretary of State John Foster Dulles after his trip across eleven Middle Eastern capitals in May 1953. This pact which was meant to block possible expansion of the Soviet Union into the Middle East ${ }^{417}$ was concluded among Great Britain, Iran, Iraq, Pakistan and Turkey. The nucleus of the pact was formed in February 1955 by a mutual defense treaty between Turkey and Iraq. The Eisenhower administration strongly supported the Turkish-Iraqi pact and hoped it would form the nucleus of a Northern Tier defense organization that the Western powers could support without actually joining. Britain, however, seized the opportunity of reviving the 1930 Anglo-Iraqi treaty and reasserting its influence among Arab states by joining the pact in April, 1955. Pakistan joined later and Iran was the last state to join the pact on October 11, 1955, interestingly, in spite of Britain's encouragement to do the otherwise. In fact, Mohammad Reza Shah, who had regained power after the 1953 coup, viewed joining the Baghdad Pact vital for the preservation of his throne and his state's capacity to contain the Soviets and counter the communist threat.

\footnotetext{
${ }^{414}$ Ali Mohaghegh, Asnad ravabet Iran va arabestan saudi (1304-1357) [Documents of Relations between Iran and Saudi Arabia (1925-1979)] (Tehran: Entesharat Vezarat Oumur Kharejeh, 2000).

${ }^{415}$ Stephen Walt, Origins of Alliance (Cornell University Press, 1990) 58.

416 ibid.

${ }^{417}$ Ali M. Ansari, Modern Iran since 1921: The Pahlavis and After. (Pearson Education, 2003) 146.
} 
This anti-Soviet regional bloc marginalized Saudi Arabia and sidelined its possible role in a regional defense pact. For obvious reasons, Saudi officials were discontent with this configuration and blasted that as blatant interventionism in the region. King Saud publicly charged the pact for strengthening Israel's position due to the wedge it created within the Arab world and the secret clauses, King Saud believed it contained, in favor of Israel and to the detriment of Arab states. Although King Saud's rhetoric in his opposition to the Baghdad Pact resembled that of Gamal Abdel Nasser and the belief that the Baghdad Pact was a colonial framework that undermined Arab interests and independence, and served the Western political and economic interests, his disappointment primarily emanated from the fact that the pact had excluded Saudi Arabia. The architect of the pact, John Foster Dulles, believed that the Arab states were not prepared to take part in an anticommunist pact because of their growing nationalism and that they were more concerned with Israel than with the Soviet Union. Another reason for the Saudi King to oppose the pact was the inclusion of Iraq and the prospect of including Jordan later on. Iraq and Jordan were two Hashemite states that had lasting feud with Saudis. The officials in Saudi Arabia believed that the Baghdad Pact was an instrument of Hashemite aggrandizement. ${ }^{418}$ Adding to his concern was the decisive alignment between Iran and the United States through the pact at a time when Riyadh was reluctant to forge a full-blown partnership with the West

${ }^{418}$ See Holden and Johns, House of Saud, 184-187; Also, George Lenczowski, Middle East in World Affairs, (Ithaca, NY: Cornell University Press, 1956) 590-592; Adeed I. Dawisha, Saudi Arabia's Search for Security. Dawisha, Adeed Isam, and Adeed Dawisha. Saudi Arabia's search for security. No. 158. (London: International Institute for Strategic Studies, 1979). 
in order to balance its relations with Egypt. ${ }^{419}$ The possibility that the Baghdad Pact could trigger an Iranian-Iraqi alliance was another unsettling feature of the pact for Saudi Arabia.

In spite of some reactionary measures such as accusing Iran of fomenting unrest among Saudi Shiite laborers employed by Aramco, and a ludicrous charge that Tehran recruited Shaban Jafari, a CIA recruit during the Operation Ajax to plot the assassination of King Saud ${ }^{420}$ Mohammad Reza Shah invited the Saudi king to pay a state visit to Iran in August 1955. During the week-long visit, the two monarchs discussed a variety of political, economic, security and military issues. They agreed on the threat of communism and expressed willingness to join the West in combating it. At the end, the two monarchs published a bilateral communique reiterating the friendship between the two nations and calling for more cooperation in political, economic and security areas. Despite the optimistic memorandum issued at the end of King Saud's official visit to Tehran, Saudi king did not leave Tehran without any grievance. Although King Saud was not pleased with the unenthusiastic reception he had received in Iran, and that Iran's claim to Bahrain was left unresolved, King Saud's anger emanated from the fact that Muhammad Reza Shah did not back down on his adherence to the 1955 Baghdad Pact, which he officially joined about two month after in October. Nevertheless, Mohammad Reza Shah agreed to support Saudi Arabia against a claim by Abu Dhabi to the Buraimi oasis when that dispute was brought up on Riyadh's initiative at the United Nations in 1956. In return, King Saud

\footnotetext{
${ }^{419}$ See Rouhollah K. Ramazani, Iran's Foreign Policy, 1941-1973: A Study of Foreign Policy in Modernizing Nations. (Charlottesville: University Press of Virginia, 1975) 276.

${ }^{420}$ Hamid Ahmadi, ravabet iran va arabestan dar sadeh bistom: doreh pahlavi [Relations between Iran and Saudi Arabia in the Twentieth Century: Pahlavi Era]. (Tehran: markaz chap va entesharat vezarat Oumur Kharejeh, 2007) 257.
} 
endorsed Iran's charge that its citizens in Bahrain, including a large merchant class, had been mistreated by the British. ${ }^{421}$

\section{Nasserism, 1956 Suez Canal Crisis and the Sinai War}

In January 1956, Saudi Arabia sought and obtained Iranian support when it brought the issue of its claim to the Buraimi oasis to the attention of the UN Security Council. Iran at the same time needed the Saudi support in its grievance over Britain's treatment of Iranians in Bahrain and other parts of the Persian Gulf region. ${ }^{422}$ Despite the cooperation on the issues of Buraimi oasis and the Iranians residing in Bahrain, the real test of the Iranian-Saudi relations in this period was the $1956 \mathrm{Suez}$ Crisis.

When Nasser consolidated his power at home, he espoused Third World neutralism at the height of the Cold War. Neutralism, for Nasser, was a means to turning Egypt to a dominant power in the wake of Anglo-French withdrawal from the region, and establishing a Pan-Arab empire from the Atlantic to the Persian Gulf under his leadership. Nasser masterfully played the superpowers against one another in order to secure the highest possible financial assistance offers. Soon, Egypt turned into a "microcosm of the East-West competition for influence in the Third World." ${ }^{423}$ Nasser believed that his dream of leading the Pan-Arab world would not come true until he could do away with three obstacles. These obstacles were the vestiges of British colonialism in Egypt, French colonial authority in

\footnotetext{
${ }^{421}$ Badeeb, Saudi-Iranian Relations, 53.

422 (See declassified confidential telegram No. 1622/4/56, dated 22 Feb 1956, from the British Embassy in Tehran to the Foreign Office in London, Public Record Office, London).

${ }^{423}$ Keylor, W. R. (1984). The twentieth-century world. Oxford University Press. 297.
} 
Algeria, and eventually Israel. Nasser viewed the Israeli state dominated by citizens of European descent in the heart of the Arab world as a return to the colonial past which posed a serious challenge to the cause of Arab unity. Therefore, Nasser took the lead in organizing the Arab states in opposition to Israel. ${ }^{424}$

The rise of Gamal Abdel Nasser in Egypt on a wave of Arab socialist ideology was an unprecedented threat to the conservative Saudi establishment. ${ }^{425}$ In a seemingly unjustified reversal of policy and a clear departure from late King Abdul Aziz's tradition, King Saud aligned Saudi policies with Egypt and Nasser's call for the adoption of unified anti-colonial policies and non-alignment in the Cold War rivalries. This "questionable alignment" has to be properly contextualized. Strengthening his position within the royal family feud could have been a contributing factor to Saud's decision to align himself with Nasser, and there is enough evidence to substantiate that claim; ${ }^{426}$ however, Saud's decision to turn to Nasser has a broader context to it.

In order to better understand King Saud's policy in this period, we need to consider the sovereignty-identity dynamic in the Middle Eastern politics. This dynamic is fueled by the strength of sub/supra-state sources of identity. Due to the lack of a rough correspondence between identity and territory, most Middle Eastern states suffer various degrees of legitimacy deficiency. ${ }^{427}$ Deficiency in legitimacy of the state has important ramifications. In states as such, citizens are not willing to embrace, or readily acquiesce to

\footnotetext{
424 ibid. 299.

${ }^{425}$ Powell, Saudi Arabia and Its Royal Family, 230-232.

${ }^{426}$ See Kechichian, Succession in Saudi Arabia.

${ }^{427}$ For a thorough analysis of this deficiency in Saudi Arabia, refer to the concluding chapter of the present work.
} 
the norms of sovereignty. The state's weakness to serve as a source of identity makes citizens susceptible to centrifugal sources of identity below and above the state level. This condition blurs the lines of national interests, negatively impacts the state's mobilization capacity, weaves irredentism into the fabric of the states, and dramatically hinders concerted foreign policy-making. Pan-Arabism as a supra-state source of identity had important effect on the behavior of Arab states. According to the ideas and ideals of PanArabism, it was expected for all Arab states to fulfill the role of defending regional autonomy from the West, promote the Palestinian cause, and cooperate with other Arab states in pursuit of common interests. Among the perennial dilemmas that Arab states have to face is navigating the contradiction between the global norm of sovereignty in which the state's interests should be a priority in foreign policy-making and the regional norms of pan-Arabism which suggest that interests should be compatible with those of the larger identity community. Balancing a defense of sovereignty and demonstrating tangible respect and adherence to pan-Arab ideals and norms is a tall order, indeed.

The conservative members of the royal family in Saudi Arabia were extremely concerned with Saud's turn to Egypt as, they thought, it would sacrifice their power and status for "chimerical Arab ideals." 428 Among the main reasons that the royal family pressured King Saud to relinquish his executive power to Faisal in March 1958 was King Saud's preferred foreign-policy choice toward Egypt. Crown Prince Faisal's grasp of foreign policy surpassed that of the King on many levels. Faisal realized that mere resistance to the pan-Arabist threat posed by Nasser would not be effective. Instead, Faisal attempted to appease Nasser while reinforcing the country's internal capabilities. Faisal

${ }^{428}$ Kechichian, Succession in Saudi Arabia. 93. 
proclaimed in behalf of his state sympathy with pan-Arab ideals but not at the expense of suppressing ties with the United States, even though Nasser had called for such a measure. $^{429}$

Despite Faisal's attempt to roll back King Saud's foreign policy blunders, Nasser had already made an inroad in Saudi politics. ${ }^{430}$ In May 1956, when King Saud made visit to Aramco facilities at the same time that the US lease of the Dhahran Air Base was about to expire, Aramco Shiite workers staged a strike featuring anti-imperialism. These strikes turned into riots when Nasser visited Dhahran in September. ${ }^{431}$ Arguably, the discourse of Arab nationalist struggle against Western colonialism championed by Nasser had inspired the unrest which Saudi officials found unsettling. In an interesting coincidence, these strikes occurred about the same time that Saudi officials had made a decision to suspend the renewal of the Dhahran Air Base agreement. ${ }^{432}$ These strikes catalyzed a reversal in that decision.

Shiites constituted one among several subsets of the Saudi society who had found Nasserist ideals appealing. The pervasiveness of this influence was to the extent that Saudi officials found strong sympathy and loyalty to Nasser and the pan-Arab cause even among the Saudi military. In 1962, when the Yemeni revolution broke out, a number of disenchanted Saudi pilots defected to Egypt, creating an embarrassment for the kingdom

\footnotetext{
${ }^{429}$ ibid. 93-94.

${ }^{430}$ ibid. 59.

${ }^{431}$ Nadav Safran, N. From War to War: The Arab-Israeli Confrontation, 1948-1967; a Study of the Conflict from the Perspective of Coercion (Pegasus, 1969).81.

${ }^{432}$ Kechichian, Succession in Saudi Arabia. 98.
} 
that further divided the King and Crown Prince. ${ }^{433}$ Interestingly enough, when Saud was deposed from power, he took refuge in Egypt and Nasser allowed him to be active through radio propaganda against Saudi Arabia. ${ }^{434}$ After this brief introduction to Nasserism, the discussion moves on to how the Suez Canal crisis served as yet another instance of IranianSaudi encounters in the region.

In mid-1956, Soviet-American competition for influence in the Middle East, the Arab-Israeli conflict, and Egyptian efforts to hasten the departure of the British and French from the Arab world converged in the Suez Canal crisis. The Suez Crisis and the way it unfolded had important ramifications for the region. The crisis was an end to Anglo-French pretensions of an imperial role in the Middle East, it bolstered Nasser's prestige in the Arab world, and helped introduce the Soviet Union as a champion of Arab aspirations. Below, a brief account of the crisis is provided to set the stage for an analysis of the Suez showdown, its aftermath and what it meant for Iranian-Saudi relations.

On June 13, 1956, Britain formally terminated its long-lasting military occupation of the Suez Canal pursuant to the agreement of October 1954. In the aftermath of the British departure, Egypt attained full responsibility of defending this important waterway. Israel perceived the British withdrawal from Suez Canal which had removed an important buffer between Israel and Egypt threatening. The removal of the British buffer in light of Nasser's growing pressure on Israel in order to enhance his image as the Arab leader most devoted to the Palestinian cause was alarming to the Israeli officials. On another front, the formation

\footnotetext{
433 ibid. 103.

${ }^{434}$ Holden and Johns, the House of Saud, 237.
} 
of the Egyptian-Syrian-Saudi alignment increased the Israel's fear of encirclement. ${ }^{435}$ In response, Israel intensified reprisal raids against its neighbors including Egypt. ${ }^{436}$

Frustrated by Nasser's growing dependence on the Soviet military assistance, ${ }^{437}$ Nasser's formal recognition of Communist China in May 1956, the United States withdrew its financial offer to the Egyptian leader on July 20, $1956 .{ }^{438}$ This move was conceivable due to increasing pro-Israeli sentiments in the Congress, The withdrawal was a blow to Nasser's prestige and his development programs, In response, Nasser retaliated by nationalizing the Suez Canal and announced that he intended to employ the revenues from the canal to domestic development projects. ${ }^{439}$ Almost three months of diplomatic effort to attain Nasser's endorsement of a multinational control of the waterway failed. This bold move increased Nasser's prestige even further, but also united his principal adversaries. Anthony Eden, the British Prime Minister, concluded that the only option available was the recourse to military force. Eden despised Nasser and viewed him as an "incarnation of Hitler." ${ }^{440} \mathrm{He}$ was resolute to seize the opportunity and topple Nasser. Nasser's record of

\footnotetext{
${ }^{435}$ See Michael Brecher, Decisions in Israel's Foreign Policy (New Haven, 1975), 254-55; also Erskine B. Childers, The Road to Suez: A Study of Western-Arab Relations. (MacGibbon \& Kee, 1962) 130.

436 Jonathan Shimshoni, Conventional deterrence: lessons from the Middle East. (Princeton University, 1986).

${ }^{437}$ On Nasser's attempts to obtain arms from the West, see Townsend Hoopes, The Devil and John Foster Dulles (Boston, 1971) 323-24; also Gail C. Meyer, Egypt and the United States: The Formative Years (Cranbury, N.J., 1980) 120-22.

${ }^{438}$ See William J. Burns, Economic aid and American policy toward Egypt, 1955-1981. (SUNY Press, 1985); Hoopes, Devil and John Foster Dulles, 336-42.

${ }^{439}$ Mohammad H. Heikal, The Cairo documents: the inside story of Nasser and his relationship with world leaders, rebels, and statesmen. (Doubledays, 1973) 66-69.

${ }^{440}$ William R. Keylor, The twentieth-century world. (Oxford University Press, 1984) 299.
} 
hostile support for Algerian rebels ${ }^{441}$ and Palestinian guerrillas made it easy for Paris and Tel Aviv to join forces with the British to retake the canal and potentially bring about Nasser's downfall. ${ }^{442}$

The successful tripartite military attack failed to achieve its political objectives. Britain, France and Israel carried out the October 29 attack without prior consultation with the United States. President Eisenhower did not believe in the utility of force against Nasser. Furthermore, he was angered by the British, French and Israelis for bypassing the United States in staging of the military campaign. Following the Sinai Campaign, the United States exerted strong diplomatic and economic pressure against the belligerents. ${ }^{443}$ As the result of the conflict, Nasser did not fall and throughout the crisis enjoyed supportive Soviet propaganda. ${ }^{444}$ Syria played a considerable role in helping Nasser as well. Syria cut the oil pipeline from Iraq which triggered a severe oil shortage in Britain and France. Eventually, Britain and France left the Suez Canal in December, and Israel withdrew from Sinai and Gaza in March 1957.

In the 1956 Suez Crisis, Mohammad Reza Shah decided to remain on the sidelines when the Arab world and many Islamic countries condemned the invasion of Egypt. ${ }^{445}$ This decision was predicated on a foundational policy rift between Iran and the Arab world.

\footnotetext{
${ }^{441}$ See also Childers, Road to Suez, 171-75; Safran, From War to War, 50-51; and Michael Brecher, Decisions in Israel's Foreign Policy (Oxford University Press, 1974) 262-64.

${ }^{442}$ See Donald Neff, Warriors at Suez (New York, 1981) 182, 275-77.

${ }^{443}$ On this point, see Dwight D. Eisenhower, The White House Years, 1956-61: Waging Peace (Garden City, N.Y., 1965), 36-40.

${ }^{444}$ Walt, Origin of Alliance, 64.

${ }^{445}$ Saudi Arabia severed its diplomatic relations with Britain and France as a result of the tripartite invasion of Egypt in 1956. The first Arab oil embargo was also imposed on Britain and France by Saudi Arabia while Iran continued its shipment.
} 
The Shah's primary concern after regaining his throne in 1953 was maximizing security and promoting economic development by aligning policies with those of the United States. The Baghdad Pact provided a modicum of security, but the Iranian government came to believe that strong ties with Israel would help Iran in several ways.

The assignment in Iran of two Israeli officials further enhanced the mutual cooperation between the two countries. Meir Ezri, a Persian native, was sent by the Israeli foreign ministry to Tehran in 1958 and remained there as minister and ambassador until 1973. ${ }^{446}$ Accompanying Meir Ezri was Jackob Nimrodi, an intelligence officer who was originally assigned to Iran on a Mossad mission, and later returned to Persia as military attaché and private businessman. ${ }^{447}$ These men were instrumental in translating the general understandings between the two parties into a network of intimate cooperation. The Iranian government believed Israel could assist Iran's economic programs, serve to strengthen Iran's ties with the United States, and balance Egyptian-Soviet alliance. Establishing and cultivating ties with Israel could preoccupy Nasser in the Arab-Israeli front for a longer time, therefore precluding the spread of his creed to the Persian Gulf region. The Iranian government in the 1950s was primarily concerned with the Soviet Union and the Sovietsupported leftist Iranian opposition groups such as the Mujahedin-e Khalq, the Tudeh Party, and the Fedayeen-e Khalq. Shah did not perceive pan-Arabism as a threat on its own

\footnotetext{
${ }^{446}$ See Meir Ezri, Anyone of His People among You - Mission in Iran (Or Yehudah, Israel: Hed Artzi, 2001) 58-169.

${ }^{447}$ Ali Fallaḥ-nezhad, Monasabāt-e Irān wa Esrā'il dar dawra-e Pahlavi-e Dovvom [Iranian-Israeli Relations in the Second Pahlavi Era] (Tehran, Markaz-e-Asnad Enghelab Eslami, 2002) 142-47.
} 
right, but he was concerned as a medium to extend the Soviet threat to the vital Persian Gulf region. ${ }^{448}$

The strategic value of Israel for Iran in meeting the challenges of internal subversion and regional aggression further encouraged the cultivation of closer economic ties as well as security and intelligence cooperation. Iran needed oil-markets following the 1954 agreement with the Consortium that replaced Anglo-Persian Oil Company, and Israel was viewed as a potential partner in this. The opening of the Tiran Straits, as the result of the tripartite military campaign against Egypt turned Eilat into a natural route for importing oil to Israel and later to Europe. In 1957, Iran and Israel began oil transactions using alien ships lest overt cooperation would harm Iran's standing with Arab nations and foment their hostility.

Keeping relations and transactions with Israel in the dark was an integral part of Iran's strategic thinking in this period. The Shah allowed the Iranian intelligence service to supervise the dealings with Israel while sidelining the natural conduit of such dealings, Iranian Foreign Ministry. In this period, Israel furnished Iranian military with high-tech equipment, and trained Iranian military officers, pilots, paratroopers, and artillery men, and the Savak personnel, yet the annals of these interactions were kept off the book. ${ }^{449}$ Fearing Arab antagonism, during these years, even the deployment of diplomatic missions was disguised much to the disappointment of the Israeli side. In Tel Aviv, the belief was that Iranian full recognition of Israel could help advance the cause of the Jewish state among hostile Arab neighbors. Despite diverging opinions, the secrecy protocol between the two

\footnotetext{
${ }^{448}$ Parsi, Treacherous Alliance, 24.

449 ibid. 26.
} 
states remained intact until few years later when the Israeli prime Minister Golda Meir broke with this tradition, brought the relations between the two states to public, and had the United States and Britain pressure Iran to recognize Israel de jure, but the Shah of Iran did not back down. ${ }^{450}$

The publicity of Iranian-Israeli dealings led Egypt's Nasser to cut diplomatic ties with Iran and embark on an anti-Iranian propaganda. ${ }^{451}$ This was an opportunity for Nasser to extend his influence to the Persian Gulf region. Soon, Cairo replaced Baghdad as the main anti-Iranian Arab propaganda hub. In an address on anniversary of the Unity Day on February 2, 1966, with the benefit of hindsight, Nasser recounted the reasons for severing ties with Iran:

The Shah had declared ... that his country recognized Israel... so a country said to be an Islamic member of the Baghdad Pact opened all opportunities of activity to Israel and helped it to work against the Arab homeland. Actually Iran became in recent years a base for Israel threatening the Arab countries.... There is a secret agreement between Iran and Israel... the two sides studied the role of Israel in the defensive systems of ...CENTO. They also affirmed the importance of reinforcing the economic, political and military cooperation between the two countries. ${ }^{452}$

Nasser's pressure on the Shah and the tripartite Egyptian-Iraqi-Soviet alliance was extremely threatening. Concerned with the weakening of Iran which could potentially redirect Iraqi's attention from the eastern borders to the possibility of an invasion on Israel,

\footnotetext{
${ }^{450}$ ibid. 26-27.

${ }^{451}$ Pishgahifard, Zahra \& Mirahmadi, Soghra. "Tahlil e tarikhi geopolitiki e ravabet e iran va mesr as jange jahani dovvom ta enghelabe eslami," [A Historical-Geopolitical Analysis of Iranian-Egyptian Relations From WWII through the Islamic Revolution]. Tarikh e Ravabete Kharejii, no. 40, (2009).

${ }^{452}$ Nasser's address on anniversary of the Unity Day, February 22, 1966, 26-27.
} 
the Jewish state supported Iran by providing intelligence on the Egyptian army as Iran was preparing for possible attacks by Egyptians or Iraqis. ${ }^{453}$ The essence of Iranian-Israeli ties in the 1950s and 1960s was not an alliance of non-Arab states in the region against the Arabs after all. Common threats and mutual needs were the reasons that motivated Israel and Iran to align policies. ${ }^{454}$

Iran's stance toward the Suez Canal Crisis which was predicated on strategic calculations strained relations between Iran and Saudi Arabia. However, the strain in the Saudi-Iranian relations eased by Mohammad Reza Shah's visit to Saudi Arabia in March 1957 at the invitation of King Saud. During the talks, King Saud, yet again, protested the Baghdad Pact, arguing that Britain, a signatory of the Pact, had attacked an Arab country. However, this time around, King Saud did not overly condemn the pact, rather he raised the possibility of improved relations with Iraq, another signatory of the pact. The heads of state also discussed the Shah's suggestion of a Saudi-Iranian Defense Pact, aimed particularly at detaching Saudi Arabia from Egypt and Syria and at improving the standing of the Baghdad Pact in the Arab world. King Saud promised to study the proposal.

The two monarchs also discussed the Saudi-British relations which had been damaged both by the dispute over the Buraimi oasis and by the Suez crisis. With the Shah's good offices, King Saud acknowledged the British interests in the region and hinted that he would resume relations with Britain if he is approached with a concrete proposal regarding the Buraimi oasis. Other Issues such the future of a number of islands in the Persian Gulf, peace and security in the Middle East, the Palestinian question and

\footnotetext{
${ }^{453}$ ibid. 27-28.

${ }^{454}$ ibid. 29.
} 
cooperation among Muslim nations were discussed in this meeting. The two leaders released a joint communique at the conclusion of the visit and both attested to the unparalleled success of their meeting.

Saudi-Iranian political relations in the aftermath of the Shah's visit to Saudi Arabia witnessed a remarkable improvement. In the closing years of the 1950s, political cooperation and identical political views began to evolve around the critical issues of the era including the Lebanese crisis of 1958, Soviet attempts to infiltrate the Middle East, Gamal Abdel Nasser's revolutionary thrusts in the region, and the 1958 replacement of the monarchical system in Iraq with a revolutionary republican regime. One of the many regional consequences of the overthrow of the monarchical system in Iraq in 1958 was the fall of the Baghdad Pact in 1959 when the revolutionary republican regime decided to withdraw from that. The demise of the pact, for the reasons mentioned, was more palatable to the Saudis than Iranians, yet it was not long before Saudis learned that there were some intrinsic merit to the Baghdad Pact they had adamantly opposed.

For all the differences Saudis had with the monarchical regime in Iraq, a modus vivendi had characterized the relations between the two. The coup orchestrated by General Abdul Karim Qasim was a total overhaul in the Iraqi Cold War orientation. Riyadh perceived Iraq with its new pro-Soviet tendencies nationalist aspirations throughout the Arab world far more dangerous than the Baghdad Pact. Qasim's nationalist vision was a call for removal Arab monarchies, and Saudi monarchy was no exception. He also believed that Saudi kingdom had to be divided into smaller entities. ${ }^{455}$ The demise of the Baghdad Pact helped Iranians to placate some of the regional concerns in Riyadh and created a better

\footnotetext{
${ }^{455}$ Kechichian, Faysal, 69.
} 
ground for the alignment of policies between the two states which the Saudi monarchy needed in face of a new host of threats in its neighborhood. 


\section{CHAPTER VI}

\section{DEVELOPMENT OF AN IRANIAN-SAUDI ALIGNMENT: CAUTIOUS AND CURTAILED (1962-1979)}

The strength of Saudi-Iranian relations was put to another test on July 24, 1960, when the Shah made a confusing statement about an extension of the de facto recognition he had given to Israel in $1950 .{ }^{456}$ In response to a question by a foreign correspondent about whether Iran had decided to recognize Israel, Shah stated that "Iran [had] recognized Israel years ago." 457 Nader Entessar attributed the recognition extended to the Jewish state by Iran as a counterbalance to the perceived Arab threat to Iran's southern frontier. ${ }^{458}$ However, this analysis is challenged by the realities on the ground at the time. This controversial move by the head of the Iranian state needs to be viewed in the framework of regional developments beginning in 1958. The developments of 1958 including the formation of the United Arab Republic of Egypt and Syria in February, the collapse of Iraq's pro-Western monarchy in July, and the subsequent collapse of the Baghdad Pact augmented Iran's concern over ramifications of the increasingly threatening expansionist rhetoric and policies pursued by Cairo. The growing concern over these developments reinforced Shah's decision to enhance Israeli-Iranian relations further. For other pragmatic reasons such as the prospect of receiving support by the American Jews having influence

\footnotetext{
${ }^{456}$ Nader Entesar, "The Lion and the Sphinx: Iranian-Egyptian Relations in Perspective" in Hooshang Amirahmadi, and Nader Entessar, eds. Iran and the Arab world. (Springer, 1993)162.

${ }^{457}$ Rouhollah K. Ramazani, The Persian Gulf: Iran’s Role, (Charlottesville, University Press of Virginia) 36.

${ }^{458}$ Nader Entessar, "Changing Patterns of Iranian-Arab Relations," Journal of Social, Political and Economic Studies, Vol. 9, no. 3 (Fall 1984) 344.
} 
in the Congress, administration, media, and business community, Mohammad Reza Shah sought closer ties with Israel.

This move roused the anger of Egyptian President Nasser and other Arab League members, calling for cutting diplomatic relations with Iran. In Nasser's view, IsraeliIranian entente was yet another manifestation of a collusion between the Shah of Iran with Western imperialism and Jewish Zionism at the expense of the Arab cause. ${ }^{459}$ President Nasser denounced the alleged recognition and labelled the Iranian leaders as "colleagues of colonialists." Echoing long-standing grievances against Iran, Nasser accused Iran of assuming "hostile attitudes" toward Egypt, the Arab nations and Arab nationalism. In an attempt to discredit the Shah in the eyes of the Arab world, Nasser and Egyptian propaganda sought to exploit religious sentiments against the Iranian regime. Accordingly, Sheikh Mahmoud Shaltout of al-Azhar University dispatch a telegram to the Shah explaining the repercussions of his move to extend recognition to Israel. Sheikh Shaltout wrote:

[the recognition of ] the Israeli gang has hurt our sentiment as well as the feelings of ulema in al-Azhar. We believe that the feelings of all Muslims in East and West have been equally injured. We consider this action contrary to the religious and cultural measures which we have taken for strengthening the brotherly relations among all Muslim peoples and which you have condoned. We should therefore hope you will reconsider this grave decision for the purpose of Muslim unity. ${ }^{460}$

\footnotetext{
${ }^{459}$ Shahram Chubin and Sepehr Zabih, the Foreign Relations of Iran: A Developing State in a Zone of Great Power Conflict (Berkeley, CA: University of California Press, 1974), 156-7.

${ }^{460}$ Ettela'at Hava'i. August 3, 1960.
} 
In response, Iran prudently responded back to the Sheikh of al-Azhar. In a reply, the Shah explained that Iran had not extended the de facto recognition of Israel in 1952, and that President Nasser's claim that Iran had recognized the Jewish state de jure was unfounded. Shah maintained that the unfoundedness of Nasser's claim demonstrated that he was trying to distract the public from Egypt's myriad of problems. ${ }^{461}$ Iranian paper, Ettela'at, elevated the hostile rhetoric against Egypt by asserting that Cairo aimed at subjugating other Arab states in order to access the vast Arab oil resources in the Persian Gulf for financing the propaganda apparatus of the Egyptian regime. Ettela'at continued that Egypt's anti-Iran propaganda was an attempt to undermine the friendly relations between Iran and the Arab nations in the region. The editorial made the case that the Nasser tried to "colonize the Persian Gulf Sheikhdoms," but he found the amicable relations between Iran and these states as an impediment and "a thorn in [his] eyes." 462

Egypt began to utilize the Arab League and its influence in its campaign against Iran. According to an editorial by Ettela'at, Abd al-Khaliq Hassounah, Secretary General of the Arab League, had warned the Persian Gulf Arab rulers of the Iranian alleged colonizing ambitions in the region. Accordingly, Hassounah made a case for the Arab Sheikhdoms that the influence of Iran in the Persian Gulf was detrimental to the Arab Nation and that it was only a matter of time before Iran took the opportune moment to rise against the Arabs. He portrayed Iran as the enemy of Islam and Arabism and assured that the Egyptian Nasser had all the intentions to stay by the Arab Sheikhdoms in their eventual war with Iran. The editorial continues:

\footnotetext{
${ }^{461}$ Ramazani, the Persian Gulf, 37.

${ }^{462}$ Editorial, Ettela'at, August 9, 1960.
} 
These are real accounts indicative of the fire that the enemy is building for the destruction of part of our national heritage. These are examples of the intrigues against the Iranians and Iranianism. These form a prelude to the destruction of Iran's influence in the Persian Gulf Sheikhdoms, for the expulsion of Iranian inhabitants from the Persian Gulf islands and for the extension of Egyptian control over the entire Persian Gulf. ${ }^{463}$

King Saud never joined the anti-Iranian campaign. Nevertheless, in an attempt to respond to such an alarming circumstance, Iran ordered its ambassadors to various Arab countries, including Saudi Arabia, to explain the situation and clarify Iran's position directly to the Arab League by promising not to recognize Israel de jure or to exchange envoys.

In December 1961, Ben-Gurion visited Tehran and met with prominent officials as the first Israeli prime minister to have ever done so. Ben-Gurion described relations between the two sides informal, "but not hidden," and based on “mutual benefit." 464 These hesitant initial steps gained significant momentum after the 1963 White Revolution, ${ }^{465}$ but they remained informal. Shah espoused an ideology predicated on nationalism, westernization, secularization, and edging closer to the West. On January 28 and March 21, 1963, Shah emphasized the spirit of his revolutionary reforms in an address to the nation:

With the God's will and the diligence of all Iranians, we will make a country that would rival with the most developed countries in the world. We will make a country that would host the land of the free, where the Iranian talents can thrive in a fertile ground free from the

${ }^{463}$ Ettela'at, Dec. 22, 1964.

464 B. Gilad, "Paras," Ha-Miazrah ha-Hadash 4/4, 1953. Seen in "Israeli Relations with Iran," Encyclopedia Iranica, retrieved on 11/2/2017. http://www.iranicaonline.org/articles/israel-i-relations-with$\underline{\text { iran }}$

${ }^{465}$ White Revolution refers to series of economic and social reforms introduced by Mohammad Reza Shah. For a brief overview, refer to Gholamreza Afkhami, "Moghaddame e bar enghelabe sefid," [An Introduction to the White Revolution] Iran Nameh, vol. 30, no. 1 (Spring 2015) 
corruption of power, and that the is the secret to the longevity of the nation. Our society does will not bear any disappointment, corruption, destruction, laxity and evasion from one's duties. The future of our society will be defined by social justice, equitable distribution of wealth, and honorable vocations in accordance to the rule of law and the necessity of providing a basic level of sustenance for all. I can vividly see this prosperous society. ${ }^{466}$

The vision that Shah had developed for the future of the Iranian society could not have been realized without any assistance. Accordingly, clearly for instrumentalist purposes, Shah turned toward Israel and sought close cooperation with Israelis. Not only this ideology permitted but also encouraged increasingly greater IranianIsraeli cooperation.

Shah viewed himself as a benevolent leader following in the footsteps of Cyrus the Great; hence, it was not difficult for him to transcend the religious differences and establish a friendship with the Jewish States. Israeli officials, on the other hand, reinforced Shah's self-ascribed vision persistently by making flattering comparisons between the Shah and Cyrus the Great in their joint-meetings. The strengthening of ties since the early 1960s also corresponded with Ben-Gurion's "periphery concept," which encouraged seeking friendship with "the neighbors of the neighbors." In the list of the countries that could contribute to that vision, Iran was perceived especially important due to its strategic location, size, and economic potential.

In this tense period, Saudi Arabia managed to maintain good relations with Iran without compromising its position in the Arab world. Once this episode was over, the

\footnotetext{
466 Shah's message to the Iranian nation after the ratification of the six principles of his reform movement, Jan. 28, 1963; Shah's New Year message to the Iranian nation, March 21, 1963.
} 
Kingdom resumed normal contacts with Iran and in 1962, Iran appointed its eighth ambassador to Saudi Arabia. Iran used the opportunity of the ambassadorial exchange to recognize Saudi Arabia as an oasis of stability in the region. Iran's Prime Minister Ali Amini on April 11, 1962 said, "The Arab countries seem to be getting more and more unstable with the exception of Saudi Arabia." ${ }^{467}$ On this positive note, Iran and Saudi Arabia entered a new era in their relations which was characterized by cautious cooperation between the two states. This period began with the ascendance of Crown Prince Faisal to the Saudi throne in November 1964 and lasted through 1979.

\section{Factors Capturing the Essence of the Period 1962-1979}

Iran and Saudi Arabia experienced relatively amicable relations from 1962 through 1979. Such amicability in spite of a variety of factors which could potentially distance the two states shapes the puzzle of the Iranian-Saudi relations in this period. Among the factors which could have negatively impacted Iranian-Saudi relations, one can note Iran's controversial de facto recognition of Israel and continued ties between the two states in the ensuing years, Iranian-Arab territorial disputes, change in Saudi leadership with the assassination of King Faisal and the ascendance to the throne by Crown Prince Khalid, withdrawal of Britain from the region and a power vacuum created thereof, Iran's demonstrable regional assertiveness and its rapid military build-up, contention over the sovereignty of Bahrain, etc.

${ }^{467}$ Interview by FRB's chief editor with Iran's Prime Minister Ali Amini on 11 April 1962, FRB 17 April 1962. 
Two factors convinced Iran and Saudi Arabia that pursuing cautious political ties, in spite of disagreements and differences, was vital to their interests. These factors are Egyptian President Nasser and his pan-Arab ideology, and cooperative norms propagated by the Nixon Doctrine. Egyptian Nasserism and Nixonian Twin-Pillar policy catalyzed relatively close ties between the two states in the 1960s and 1970s respectively.

After the overthrow of Egypt's pro-Western monarchy in 1952 and the emergence of a radical nationalist regime under the leadership of Colonel Gamal Abdel Nasser, Egyptian foreign policy took a decidedly pan-Arabist turn. Increasingly, the new Egyptian government saw itself as the defender of Arab causes and promoter of Arab unity in the Middle East. Nasser's activist foreign policy propelled the country into a leading position in the nascent non-aligned movement. Among various strategically important regions, Nasser had specifically honed in on the Persian Gulf region where the British had heavy political and military presence. In addition, Nasser was particularly opposed to the formation of the Baghdad Pact, which was designed to promote Western interests by offering a counterweight to the Soviet threat and the challenge of radical nationalism.

Nasser perceived Iran's close ties with Israel and the West as an indication that Iran was anathema to the Arab cause he was promoting. In his strategic thinking. Therefore, Nasser found utility in countering any improvement in relations between Iran and its neighboring Arab states. He launched a campaign from Cairo to refer to the Persian Gulf and the oil-rich Khuzestan province as the "Arabian Gulf," and "Arabistan" respectively. In another attempt to poison the Iranian-Arab relations, the Egyptian government drew parallel between Iranian immigration to the Persian Gulf states and the 
Zionists' immigration to Palestine. ${ }^{468}$ In spite of this bitter rhetoric, Nasser's opposition to Western pacts and monarchical regimes, ${ }^{469}$ and his enthusiasm for non-alignment during the Cold War unlike the Shah's reluctance of that policy choice, Iran's real concern with regard to Nasser and his pan-Arabist ideology rested elsewhere. The Iranian government's concern was about Arab radicalism functioning as a medium for Soviet interventionist policies.

Unlike Iran that perceived the Egyptian growing influence in the region primarily through pure Cold War geopolitical considerations, Saudi Arabia had more reasons to feel apprehensive of Nasser's eastward move and the ideological narrative he championed. Nasser's supra-state identity of pan-Arabism was a serious challenge for those polities in the Middle East where there was an absence of any rough correspondence between identity and territory. These are the polities that typically face legitimacy deficiency and massive upward pressure on the state from centrifugal forces within society that refuse to readily acquiesce to the state sovereignty. Saudi Arabia represents one of such polities. Exposure to Nasser's pan-Arabism as a strong supra-state source of identity placed Saudi rulers in a difficult dilemma. The pan-Arab ideals normatively pressured Arab states to defend the notion of regional autonomy from the West, promote the cause of the Palestine and cooperate with other Arab states for common interests. Adherence to these ideals are anathema to the sovereign status and independent foreign policy-making of the state, yet

\footnotetext{
${ }^{468}$ Shahram Chubin, and Sepehr Zabih, The Foreign Relations of Iran: A Developing State in a Zone of Great Power Conflict (Berkeley, CA: University of California Press, 1974) 148.

469 ibid. 143.
} 
walking away from those ideals would cost further deepening of the legitimacy crisis. ${ }^{470}$ Saudi Arabia, unlike Iran, was extremely permeable to Nasserism as a trans-state ideology. This could shake the foundations of any state as young as Saudi Arabia. Initially, Saudis tried to appease Nasser, but as Nasserism gain further strength and its threat to the foundation of the Saudi state grew in intensity, Saudi officials shifted from bandwagoning to balancing, a policy move that brought about Iranian-Saudi cooperation on several fronts in this period.

The other factor that helped Saudi-Iranian relations continue with its remarkable growth into 1970s was the consolidating effect of the cooperative norms that the 1969 Nixon Doctrine set forth. During the latter half of the 1960s, Iran and Saudi Arabia learned how to cooperate in certain areas without letting their disagreements and rivalry disrupt their relationship. The Nixon Doctrine's Twin Pillar policy further solidified the IranianSaudi relations. Following Britain's decision to withdraw from the region, Nixon administration promoted Iran, and to a lesser extent Saudi Arabia, as guardians of regional security and as bulwarks against Soviet expansionism. ${ }^{471}$ This policy involved the provision of military armaments to these two key allies with the aim of achieving regional security. $^{472}$

Understanding the context in which the United States introduced the Nixon Doctrine is essential to better understanding of the roles Iran and Saudi Arabia were

\footnotetext{
${ }^{470}$ Raymond Hinnebusch, The international politics of the Middle East. (Manchester University Press, 2010) $72-73$.

${ }^{471}$ Henry Kissinger, the White House Years (London: Weidenfeld \& Nicolson, 1979) 1262-65.

${ }^{472}$ F. Gregory Gause III, "British and American Policies in the Persian Gulf 1968-1973," Journal of International Affairs 45.2 (1985).
} 
assigned accordingly. When Richard Nixon took office in early 1969 after running a campaign on the promise of "peace with honor," the signs indicating the failure of the United States involvement in the Vietnam War were abundant. With thousands of US soldiers having lost their lives and countless anti-war protests going on around the country, Washington realized that the prospect of victory in Vietnam was not promising. The Vietnam syndrome warranted a novel approach in fulfilling American commitments around the globe. In a statement that President Nixon made during a stopover in Guam, the Asian allies of the United States were encouraged to take on their own defense, except for the threats involving nuclear weapons. In a report to Congress on February 25, 1971, President Nixon spelled out his doctrine:

It is no longer natural or possible in this age to argue that security and development around the globe is primarily America's concern. The defense and progress of other countries must be first their responsibility and second a regional responsibility. ${ }^{473}$

According to the doctrine, the United States pledged to provide its allies with massive aid and armaments so that they could more actively partake in regional security tasks vital to the United States. In his report to the Congress in 1971, President Nixon explained the function of "security assistance" as such:

By fostering local initiative and self-sufficiency, security assistance enables us...to reduce our direct military involvement abroad ...[and] lessen the need for and likelihood of the engagement of American forces in future local conflicts. Thus, it will ease the burden of the United States. But at the same time it signals to the world that the United States continues to help and support its allies....[America will assist] friends and allies who are shouldering the burden of their own and regional security. ${ }^{474}$

\footnotetext{
${ }^{473}$ See Nixon Doctrine in "US Foreign Policy for the 1970s: Building for Peace," A report to the Congress by Richard Nixon, Feb. 25, 1971.

474 ibid.
} 
The United States allies in the Persian Gulf region were pro-American regimes of Iran and Saudi Arabia. These two states constituted the two pillars of Nixon doctrine's twin-pillar policy. The policy was effective because the roles assigned to Iran and Saudi Arabia were consonant with their self-image as status-quo powers in the region. ${ }^{475}$ These identical roles assigned to both states increasingly reinforced an already expanding alignment of policies between the two.

The United States, in accordance with the Twin-Pillar doctrine, empowered both Iran and Saudi Arabia with sophisticated military hardware and training assistance. ${ }^{476}$ Between the two pillars, the US relied more on Iran than Saudi Arabia given its military might and stability. Kissinger writes in his White House Years:

There was no possibility of any American military forces to the Indian Ocean in the midst of the Vietnam War and its attendant trauma. Congress would have tolerated no such commitment; the public would not have supported it. Fortunately, Iran was willing to play this role. The vacuum left by British withdrawal, now menaced by Soviet intrusion and radical momentum, would be filled by a local power friendly to us. Iraq would be discouraged from adventures against the Emirates in the lower Gulf, and against Jordan and Saudi Arabia. A strong Iran could help damp India's temptations to conclude its conquest of Pakistan. And all of this was achievable without any American resources, since the Shah was willing to pay for the equipment of his oil revenues. ${ }^{477}$

\footnotetext{
475 Arshin Adib-Moghaddam, The international politics of the Persian Gulf: a cultural genealogy (Routledge, 2006) 12.

${ }^{476}$ See John E. Peterson, "The Historical Pattern of Gulf Security," in Lawrence G. Potter and Gary G. Sick, eds. Security in the Persian Gulf. Origins, Obstacles, and the Search for Consensus, (Houndmills: Palgrave, 2002), 7-31.

${ }^{477}$ Henry Kissinger, The White House Years (Simon and Shuster, 2011) 1264.
} 
According to the Nixon's doctrine, Iran benefited from almost unlimited access to the US weaponry with its status as the "gendarme of the Persian Gulf," at the invitation of Sultan Qabus, Iranian troops defused a Marxist separatist uprising in Oman's Dhofar province in $1973 .{ }^{479}$ Kayhan, a prominent Iranian press outlet, captured the essence of Iranian military intervention in Oman in an editorial on February 4, 1974 titled "In Defense of the Persian Gulf" as such:

The announcement that Iranian troops have scored military successes in Oman proves this country's determination to be as good as its word in aiding its neighbors to preserve their independence and territorial integrity. Iranian troops have been dispatched to Oman at the invitation of the Omani government. Their participation in Oman's efforts to frustrate attempts against its very existence is in accordance with Iran's declared policy of resisting subversive activities in this region. Again and again, Iran has made it plain it shall not tolerate plots to turn the Persian Gulf region into backwater of this or that colonial or neo-colonial empire. And yet, the rebellion in Oman is clearly fostered, aided and abetted by hegemonic powers dreaming of gaining control of the Straits of Hormuz, the key to the Persian Gulf. Everyone knows that keeping the Persian Gulf secure and free for international navigation is a matter of life and death to Iran. Everyone knows that Iran shall not allow this region's vast resources to fall into hands of this or that power bloc so that they can be used as pawns in international power chess. Iranian soldiers have fought valiantly, demonstrating their resolve and ability to help a friendly country in need of support against international conspiracies. ${ }^{480}$

Following the Iranian assistance to the Omani government, Oman's new ambassador to the Imperial Court, Ismael al-Rasasi expressed gratitude on behalf of his nation upon his arrival in Tehran on February 5, 1974. He pointed out to the Pars News Agency at the Omani Embassy:

\footnotetext{
${ }^{478}$ See Jacob C. Hurewitz, "The Persian Gulf: British Withdrawal and Western Security." The Annals of the American Academy of Political and Social Science 401, no. 1 (1972) 106-115.

${ }^{479}$ See Calvin H. Allen and W. Lynn Rigsbee II. Oman under Qaboos: From coup to constitution, 19701996 (Routledge, 2014); also Mohammad Jafar Chamankar, "Ravabete iran ba oman dar doreye Pahlavi" [Iranian-Omani Relations during Pahlavi Era] Tarikhe Ravabete Khareji. no.16 (2003).

${ }^{480}$ Kayhan International, February 10, 1974.
} 
Iran's assistance to Oman has had great positive effects on the establishment and preservation of security [emphasis added] in this region and that Oman will always be thankful for this assistance which is a manifestation of friendly and correligious ties. The Omani nation joins me in expressing their thanks. ${ }^{481}$

It is interesting how the Nixon Doctrine tamed Saudi's apprehension over Iran's growing regional power and influence due to Washington's military aid to Iran and the Shah's regional aspirations. Perhaps, Saudi's 69 percent higher fiscal revenues in 1971 compared to Iran had made King Faisal confident that Saudis could dash for parity once the need emerged, ${ }^{482}$ nevertheless, Iran was never perceived as a threat in Riyadh under Faisal.

The rest of the chapter examines the highlights of the Iranian-Saudi relations from 1962 through 1979 in order to make the case for how the threat of Nasserism in the 1960 s and then Nixon's Doctrine in the 1970s helped Iran and Saudi Arabia transcend their seemingly irreconcilable differences, and cooperate on many levels.

\section{Key Features of King Faisal's Reign 1964-1975}

Upon his ascent to the throne, King Faisal was arguably the most experienced living Arab leader. Faisal had years of experience partaking in wars, governing as the viceroy of Hijaz, and interacting with world leaders in various capacities. The first obligation that he undertook after ascending to the throne was restoring order to the royal family, which was

\footnotetext{
${ }^{481}$ New Oman Ambassador Views Relations with Iran, Tehran Domestic Service, February 5, 1974. FBISMEA-74-031, Feb. 1, 1974.

${ }^{482}$ Keynoush, Saudi Arabia and Iran, 90.
} 
weakened due to prolonged family in-fighting. ${ }^{483}$ Other outstanding features of King Faisal's rule which distinguished his era from that of his predecessor were "increased centralization of power, greater internal stability, and clearer policy direction." ${ }^{484}$ As the result, the distribution of power within the monarchy became more harmonious and key foreign policy decisions eventually altered the image of the kingdom permanently.

During King Faisal's reign, Saudi oil revenues skyrocketed causing a GDP growth from 10.4 billion in 1965 to 164.5 billion in $1975 .^{485}$ This allowed the Saudi state to consolidate the redistributive role of the central government. During the reign of King Abdul Aziz, access to foreign subsidies and fund helped the founder of the Saudi Kingdom reward allegiances. Within almost a decade, under Faisal, the massive oil revenue surplus enabled the state not only to secure allegiance of its citizens, but also transform many aspects of their lives. With the oil money, King Faisal initiated his modernization projects by importing technological expertise and heavily investing in developing material infrastructure and education. During his reign, King Faisal consolidated the Saudi state by "merg[ing] important branches of the royal lineage with state machinery," and successfully countering the discourse of constitutional monarchy, Arab nationalism, and socialism propagated by his deposed brother, Talal ibn Abd al-Aziz and other Free Princes. ${ }^{486}$ Under Faisal's patronage and his bureaucratic reforms, major senior ulama were formally coopted and became state functionaries. Concessions to the ulama were made in return for

\footnotetext{
${ }^{483}$ Joseph A. Kechichian, Faysal: Saudi Arabia's king for all seasons. (University Press of Florida, 2008), 106.

484 ibid. 45 .

${ }^{485}$ Madawi Al-Rasheed, A History of Saudi Arabia. (Cambridge University Press, 2010) 116.

486 ibid. 118-119.
} 
religious decrees granting authenticity and legitimacy to almost every aspect of his social and economic reform. ${ }^{487}$ Not only did the success of Saudi renaissance figure overshadow the tumultuous years of King Saud's reign, but also a historical amnesia regarding this era was encouraged. ${ }^{488}$

King Faisal rejected Arab nationalism in its both Nasserite and Baathist versions. Nasser's pan-Arabism, and the Ba'athi call for "unity, freedom and socialism" under the banner of a single Arab nation, in Faisal's viewpoint, were direct threats to the ruling family. The August 1967 humiliation of the Arab leaders was a big blow to Nasser's leadership. Even though his popularity did not abate in the Arab world, but he lost much of his bargaining power with other Arab states. However, around the same time, Iraqi and Syrian Ba'athism emerged. Faisal rightfully perceived Arab nationalism in its Ba'thist version as yet another threat to the legitimacy of Al-Saud rule. The Ba'athist discourse of Arab unity which was fundamentally predicated on secular Arab culture and socialism was clearly against Saudi Arabia's raison d'etre. While in the 1950s and early 1960s Cairo had been the center for anti-Saudi activities, in the late 1960s, Baghdad became the hub for oppositionists to Saudi rule. Not only were Saudi Ba'athists allowed to broadcast their anti-Saudi propaganda from Baghdad, but also they published a journal — popular among Ba'athists and leftists — titled Sawt al-Talia's. ${ }^{489}$

\footnotetext{
487 ibid. 120.

488 ibid. 119.

${ }^{489}$ Al-Rasheed, A History, 126.
} 
To counter the pressure of Arab nationalism, King Faisal turned to Islam and non-Arab Muslim countries. ${ }^{490}$ The architect of lining religion to foreign policy was King Faisal's son and Saudi foreign minister, Prince Saud al-Faisal who believed that "by promoting universal Islamic solidarity, the House of Saud [could] escape the specter of pan-Arabism that had haunted it since the 1950s." ${ }^{" 491}$ In this pursuit, he began to support Muslim countries in Africa and Asia. In 1974, he contributed 10.2 million dollars to the Islamic Solidarity Fund, and catalyzed the establishment of Islamic Development Bank. ${ }^{492}$ With these measures, Saudi Arabia gradually became the symbol of Islamic politics defying the pervasively negative image of the country in the Muslim world in preceding decades.

Aware of the Saudi's vulnerability to internal and external threats, King Faisal secured the military protection of the United States as a reliable extra-regional, non-Arab guarantee for the security of Saudi Arabia. ${ }^{493}$ In this pursuit, relying on its emerging oil wealth, Saudi Arabia ventured into the world of petro-politics to balance various tactics to survive and prosper. With a novel pro-business slant, Faisal tied the Western oilappetite to the necessity of balancing the threats posing the kingdom. This was not an easy order considering the Cold War contingencies. Before Faisal's rise to power, King Saud's foreign policy blunders and attitude toward the United States weakened the Saudi appeal to keeping the US interested and involved in Saudi politics; however, one cannot

\footnotetext{
${ }^{490}$ Alexei Vassiliev, The History of Saudi Arabia (Saqi, 2013) 385.

491 Sandra Mackey, The Saudis: Inside the Desert Kingdom, (Boston, Houghton Mifflin Company, 1987) 326.

492 James Piscatori, "Islamic Values and National Interest: The Foreign Policy of Saudi Arabia," in Adeed Dawisha (ed.), Islam in Foreign Policy, (Cambridge University Press, 1983)

${ }^{493}$ Foreign Relations of the United States, 1964-1968, 21: 424-612.
} 
neglect the Cold War developments such as the Soviet invasion of Hungary and Czechoslovakia, Cuban missile crisis, and the Chinese Cultural Revolution which had consumed the US foreign policy-makers to the extent that they did not deem the Middle East as a high-profile policy arena until the 1967 and 1973 Arab-Israeli conflicts. These two conflicts restored the status of the Middle East in the American strategic thinking. In this context, building upon an "institutional memory buttressing the [partiality] of the AlSaud ...to the United States," American-Saudi ties reemerged in full force. ${ }^{494}$

During his reign, King Faisal securely guided the Saudi state through some tumultuous years characterized by internal and external threats to the Saudi rule. Despite upheavals, dissidence, and terror plots at home; the Nasserite, Arab nationalist, Ba'athist, socialist and communist threats from the outside; and the difficulty of navigating ArabIsraeli conflict, Faisal managed to consolidate the Saudi state of 1932, introduce and carry out important modernization projects, and bring Saudi Arabia an unprecedented recognition in both Arab and Islamic world.

\section{Iranian-Saudi Encounters during King Faisal's Reign}

The Shah of Iran had prior encounters with Faisal and thought highly of the new King's competence as a statesman. In December 1965, Mohammad Reza Shah hosted King Faisal in Tehran. ${ }^{495}$ The Shah was eager to cooperate with the King's vision for the Muslim world to fight communism. In this meeting, the two monarchs affirmed their agreement on practical concerns in the Persian Gulf region such as Soviet ambitions in the region,

\footnotetext{
${ }^{494}$ Kechichian, Faysal, 152.

${ }^{495}$ Pirouz Mojtahed-Zahed, Security and territoriality in the Persian Gulf: A Maritime Political geography. (Routledge, 2013), 46.
} 
Nasser's moves in the Middle East, the matter of oil, and the situation in North Yemen. After his successful visit to Iran, King Faisal paid similar visits to Jordan, Sudan, and Pakistan. Iran described King Faisal's visit to Iran and those subsequent ones as "a step to prepare the grounds for the unity of Islamic countries.”

During King Faisal's visit to Iran, the two sides signed a cultural agreement which served as a foundation of cultural cooperation in the ensuing years. Accordingly, Iran and Saudi Arabia agreed to closely collaborate in exchanging scholarship students, facilitating the meeting of cultural figures and consortiums, and conducting joint scientific and cultural projects. ${ }^{496}$ In addition to mutual understanding in the matters of low politics, in the years to follow, Iran collaborated with Saudi Arabia in the Muslim World League and helped establish Organization for Islamic Conference in $1969 .{ }^{497}$ The idea of the Organization of Islamic Conference stemmed from King Faisal's vision that such an organization would widen the scope of regional politics to include non-Arab Muslim states to dilute Egypt' influence in the region. ${ }^{498}$

Maintaining ties with Saudi Arabia was arguably important for the Shah of Iran. After King Faisal's visit with the Shah, Iran tried to allay Saudi's concern over IranianIsraeli ties by publicly supporting Saudi Arabia. The highest point of such an effort was in

\footnotetext{
${ }^{496}$ See Karim Soleimani, "monasebate farhangiye iran va arabestan dar beyne salhaye 1345 va 1355," [Iranian-Saudi Cultural Relations, 1966-1976] Tarikhe Ravabete Khareji, no. 21 (2004).

${ }^{497}$ Banafsheh Keynoush, Saudi Arabia and Iran: Friends or Foes? (Springer, 2016), 85; The Organization of Islamic Cooperation was established upon a decision of the historical summit held in Rabat, Morocco on September 25, 1969 a week after the arson of AL-Aqsa Mosque in Jerusalem. The organization aims to be the "collective voice of the Muslim world" and "protect the interests of the Muslim world in the spirit of promoting international peace and harmony among various people of the world." (OIC website, retrieved on $5 / 16 / 16$ )

${ }^{498}$ Gregory Gause, Saudi-Yemeni Relations: Domestic Structures and Foreign Influence (Columbia University Press, 1990) 69.
} 
June 1966 when the Iranian press criticized the mayor of New York City for his "rudeness" towards King Faisal during his June 1966 visit to the United States. Mayor John Lindsay was supposed to host King Faisal but he cancelled the dinner party after Faisal publicly attacked Zionism during a Washington press meeting. This position by the Iranians encouraged the Saudi Foreign Minister to pay an official five-day visit to Tehran. At the formal airport reception on June 21, 1966, Seyyed Omar al-Saggaf, the Saudi Foreign Minister, said that the Iranian-Saudi friendship was a perfect example of Islamic brotherhood and neighborly relations. ${ }^{499}$ In an interview, Saggaf identifies "friendship with Iran [as] the cornerstone [of the kingdom's] foreign policy." ${ }^{500}$ These developments reinforced Iranian-Saudi partnership further.

The strategic importance of this partnership was to the extent that the Shah of Iran introduced an unprecedented rhetoric that fit King Faisal's vision of Islamic unity. Mohammad Reza Shah allegedly maintained that neither could theological differences undermine the Iranian-Saudi partnership nor Iranian-espoused Shiism was meant to overshadow the Saudi role in the Islamic world. ${ }^{501}$ Aside from the connections at the personal level, geopolitically, the snapshot of the 1960s demonstrates that Riyadh and Tehran, in spite of ebbs and flows, sought to establish closer ties in order to coordinate their oil policies within the Organization of Petroleum Exporting Countries (OPEC), curb

\footnotetext{
${ }^{499}$ ibid, 85-86.

${ }^{500}$ Keyhan International, Dec. 12, 1982.

501 ibid. 86.
} 
Nasser's moves in the region, and collaborate to maintain the regional peace and security. $^{502}$

\section{Arab-Israeli War}

During the 1967 Six-Day War, Israel crushed its Arab neighbors and seized parts of Egyptian, Jordanian, and Syrian territories. The seemingly desirable outcome of the conflict ensured the Iranian government that Israel remained strong enough to balance the Arabs who were susceptible to the Soviet influence. In other words, Israel's weakness could have meant the reinvigoration of the Soviet threat to Iran. However, these developments proved to be more complicated for Iran. Even though Iran benefited from Israel's balancing weight, it was also wary of Israel's rise to regional predominance which could have challenged "Iran's quest for preeminence or its strategic significance in Washington." ${ }^{, 503}$ Iran needed to take a stance on Israel's aggressive posture and its refusal to return seized Arab territories. This was a tough call as both warring factions looked forward to an Iranian response favorable to their own objectives. Tel Aviv expected that its show of force during the war would prompt Iran to recognize the Jewish State de jure, which Iran had refused to do so. The Shah refused to honor Israel's wishes and instead stated that "any occupation of territory by force of arms shall not be recognized. A permanent solution for the existing differences between Arab states and Israel must be

\footnotetext{
${ }^{502}$ For example, about the troubled situation in Jordan and its spillover effect for the region during mid1966, Mohammad Reza Shah had privately stated his concern at the possible repercussions of the Jordanian crisis in Saudi Arabia. (FRB, 9 Dec. 1966).

503 Trita, Parsi. Treacherous alliance: the secret dealings of Israel, Iran, and the United States (Yale University Press, 2007) 30.
} 
found within the framework of the UN charter." ${ }^{504}$ Iran supported UNSC Resolution 242 calling for the "withdrawal of Israeli armed forces from the [occupied] territories, and privately pressured Israel to comply with the resolution. ${ }^{505}$ Iran was not willing to demonstrate any sign of appreciation for Israel's rise to power which made Tel Aviv suspicious of Shah's intentions. ${ }^{506}$

This was a "substantive shift" in Iranian attitude toward Israel. ${ }^{507}$ Added to the geopolitical considerations informing the Iranian government's reluctance to side with Israel, one has to take into consideration the domestic dynamics encouraging Iran's unprecedented move. Iranian government's decision to turn its back on Israel and side with the Arab world could be seen as a pragmatic response to the strengthening of the domestic anti-Israeli rhetoric throughout the 1960s, particularly among the clergy and the anti-Shah and anti-Western elements. Most prominent among these spokesmen was Ayatollah Ruhollah Khomeini, who, in a speech on June 3, 1963, asserted, "[Israel wishes] to seize your economy, to destroy your trade and agriculture, to appropriate your wealth." He continued that Israel wished to make Iran bereft of the Quran and ulama. ${ }^{508}$ Therefore, Shah's anti-Israeli posture alleviated some of the pressure that the opposition front put on the government in this regard.

\footnotetext{
504 ibid. 31.

505 ibid.

506 ibid.

${ }^{507}$ Shah's interview with Borba, a Yugoslavian newspaper, quoted in Parsi, Treacherous Alliance, 31.

508 See Ruhollah Khomeini. Islam and Revolution: Writings and Declarations of Imam Khomeini (19411980). (Mizan Press, 1981).
} 
Even though King Faisal was not utterly satisfied with Iran's response to the SixDay War, mutual understanding between the two monarchs about their limitations helped the two countries conduct their bilateral relations cautiously. In this regard, Shah's open condemnation of Israel's occupation of Arab lands and his call for immediate withdrawal of Israeli forces from occupied territories, ${ }^{509}$ was enough for King Faisal to pay a visit to Iran in December 1967. In a speech to the Iranian parliament, King Faisal emphasized Islam as the binding element between the two nations which had helped the Iranian-Saudi bond emerge from this turbulent phase of relations intact. Saudi King particularly directed his speech to the Shah, who was present at the Parliament Hall, saying, "Now is the time for more cooperation and coordination between the two countries." King Faisal referred to Iranian and Saudis as brothers in faith who had shared interests in the region. ${ }^{510}$ The visit served its purpose, and the monarchs agreed that their Foreign Ministers would meet occasionally to exchange views. King Faisal also invited the Shah to visit Saudi Arabia the following year.

\section{2-1969 Yemeni War}

The partnership between the two states in the 1960s was beyond rhetoric. On September 19, 1962, a military coup in North Yemen — supported by Egyptian Nasser — overthrew the Imamate and replaced it with a republican system hostile to Saudi Arabia. Iran stood by Saudi Arabia and withheld recognition of the new regime. On November 20, 1962, Shah in an interview with the chief editor of Foreign Reports Bulletin expressed his

\footnotetext{
${ }^{509}$ Iran Almanac and Book of Facts, 7th vol. (Echo of Iran, 1968) 236.

${ }^{510}$ Saeed M. Badeeb, Saudi-Iranian Relations 1932-1982 (Al Saqi, 1993) 60.
} 
worries over the Egyptian intervention in Yemen, calling it an attempt to gain control of the Arabian Peninsula's oil reserves. ${ }^{511}$ Later, when Nasser intervened militarily in North Yemen, Saudi Arabia and Iran extended political and military assistance to the ex-Imam of Yemen, who was fighting to regain his throne. On August 24, 1965, President Nasser pledged to King Faisal that he would withdraw Egyptian troops from Yemen by November 1966.512

In the aftermath of Nasser's defeat in 1967, the rise to power of a socialist regime in south Yemen and the prospect of unification of the two Yemens made King Faisal apprehensive of the potential threats to the regional position and stability of Saudi Arabia. When the leftist regime of People's Democratic Republic of Yemen (PDRY) gained further strength by co-opting Ba'athist and communist groups, it called for the liberation of the Arabian Peninsula. This call was followed by an attack on the Saudi territory in 1969. In an unprecedented move, King Faisal turned to Iran for help, and Mohammad Reza Shah obliged. Relying on its close ties with the Johnson administration, the Shah of Iran urged the United States to provide military assistance to Riyadh. ${ }^{513}$

By the mid-1960s, Egypt's military involvement in Yemen had backfired and Nasser's pan-Arabism had begun to lose its enchantment in the region's conservative Sheikhdoms. At home, Nasser's Yemeni quagmire had become increasingly unpopular, and by 1966, Nasser was struggling to extricate himself from Yemen without losing

\footnotetext{
${ }^{511}$ FRB, 28 November, 1962.

${ }^{512}$ Gregory Gause, Saudi-Yemeni Relations: Domestic Structures and Foreign Influence (Columbia University Press, 1990) 68.

513 Alinaqi Alikhani, yad dasht ha-yi asaddollah alam, [The Diaries of Alam], vol. 1, 1968-1969 (Tehran: entesharat maziar va moin, 1998), 298.
} 
prestige among the Arabs of the Persian Gulf. Ironically, it was the June 1967 Arab-Israeli war that provided the outlet for Nasser to end Egypt's military involvement in the Arabian Peninsula. Exhausted by the futile military engagement in Yemen and devastated by the swift military defeat of Egypt in the June 1967 war, Nasser began to reassess Cairo's ambitious goals in the Arab world. This reassessment apparently entailed a shift in Nasser's hostile rhetoric against the Shah, and a drop of the "Iranian threat" narrative that had informed Egypt's pre-1967 policy in the Persian Gulf. As a consequence, a rapprochement began to develop between Iran and Egypt.

\section{Territorial Disputes in Anticipation of the British Withdrawal from the Region}

On January 16, 1968 Britain's Labor government headed by Prime Minister Harold Wilson and his Defense Secretary, Denis Healey announced that there would be a total withdrawal of British forces stationed east of Suez by the end of $1971 .^{514}$ The British decision marked the end of more than a century and a half of British dominance in the Persian Gulf and the opening of a new chapter in its history. For the first time in the modern era, the Persian Gulf states had to assume responsibility for the security of the region. However, there were strong signs indicative of the British decline as early as 1940s. The fall of Singapore to the Japanese on February 15, 1942 was detrimental to the British Empire, its image and influence after World War II. ${ }^{515}$ Then, with Indian independence in

\footnotetext{
${ }^{514}$ Saki Dockrill, Britain's Retreat from East of Suez: the Choice Between Europe and the World? (Palgrave Macmillan, 2002); Shohei Sato, "Britain's Decision to Withdraw from the Persian Gulf, 1964-68: A Pattern and a Puzzle," Journal of Imperial and Commonwealth History, 37.1 (2009) 99-117.

515 Tim Harper, “Japan's Gigantic Second World War Gamble”, The Guardian, retrieved on 08/04/16, https://www.theguardian.com/world/2009/sep/07/japan-imperialism-militarism
} 
1947, there was a gradual draw-down of the military presence "East of Suez," which ensured the eventual collapse of the empire. ${ }^{516}$ The Suez Crisis and associated diplomatic and military confrontation in November 1956 ending in Egypt taking full control of the canal marginalized the economic and military influence of Britain over the region, and limited its control over the bases in the Middle East and Southeast Asia. ${ }^{517}$ These developments led London to reassess the British commitments in the region.

Britain desired to leave behind a stable regional structure after withdrawal. ${ }^{518}$ Therefore, on January 9, 1968, during his trip to the Persian Gulf to announce the pending British withdrawal, Foreign Secretary Goronwy Roberts is reported to have said that British policy was to encourage mutual co-operation among the Persian Gulf states in matters of defense. ${ }^{519}$ Iran at the time was considering a regional pact to replace CENTO that would include Saudi Arabia, Kuwait and Pakistan. ${ }^{520}$ Iran was not opposed to the notion of regional cooperation, but this excluded any defense and regional security proposal that included Bahrain. Iran signaled that it is determined and prepared to protect its own regional interests once the British withdrawal was complete. Iranian Prime Minister, AmirAbbas Hoveida asserted, "the Imperial Iranian Government can undoubtedly protect its interests and rights in the Persian Gulf without allowing outside powers to interfere.” He continued that Iran had "... no problems with the Arabs unless they create some ... [or]

\footnotetext{
516 John Darwin, "Britain, the Commonwealth and the End of Empire," BBC. retrieved on 08/04/16, http://www.bbc.co.uk/history/british/modern/endofempire_overview_01.shtml; Also, John E. Peterson, Defending Arabia, (Routledge, 2016).

${ }^{517}$ Peterson, Defending Arabia.

${ }^{518}$ Faisal bin Salman Al-Saud, Iran, Saudi Arabia and the Gulf: Power Politics in Transition (IB Tauris, $2003) 30$.

${ }^{519}$ Daily Telegraph, 9 January 1968.

${ }^{520}$ Al-Saud, Iran, Saudi Arabia. 30
} 
think that they should be heirs to British colonialism." ${ }^{521}$ In an interview with A.M. Rendel of the Times in May 1968, the Shah reinforced the same stance:

As regards the Arab countries, we really do not have any problems with them unless they create one. The only difficulty is that certain of these Arab countries that presently exist or are about to be created, believe that they must become the successors and heirs of Britain ancient imperialism. If they want to follow this path, we will have out difficulties. Otherwise, we do not have any problems between us. ${ }^{522}$

In this way, Iran set the tone of the early years leading up to the British withdrawal from the region. Iranian government was of the opinion that any long-term regional arrangements are contingent upon the settlement of territorial disputes. ${ }^{523}$ Iranian-Arab territorial claims over Bahrain and the Hormuz islands were the most notable of such disputes. Other disputed issues that Iranians were concerned about were the formation of the federation of Arab emirates and the maritime dispute between Iran and Saudi Arabia. These disputes dominated the Persian Gulf agenda in the late 1960s.

During the first two months of 1968, all the territorial disputes between Iran and the lower Gulf Arabs were brought to the fore. On January 15, shortly before the Shah was due to pay an official visit to Saudi Arabia, the Emir of Bahrain was formally received by King Faisal during the time when the long-standing claims to Bahrain was the dominant theme of the Iranian press. During the visit, Saudi Arabia and Bahrain decided to build a causeway bridging the two countries. ${ }^{524}$ They also issued a joint communiqué emphasizing

\footnotetext{
521 ibid. 31. Tehran's rhetoric in these years resembled that of Cairo and Baghdad but nationalistic tendencies in Iran made any rapprochement with the radical Arab camp impossible.

${ }^{522}$ The Times, London, April 13, 1970.

${ }^{523}$ ibid. 32.

${ }^{524}$ Times, 18 January 1968.
} 
the strong historical bonds between the peoples of Bahrain and Saudi Arabia, Saudi Arabia's full support for the government of Bahrain, and the prospect of further economic cooperation. ${ }^{525}$ King Faisal assured Shaikh Eisa that, "any attack on Bahrain would be treated as one on Saudi Arabia and met with all his country's resources." ${ }^{, 526}$ Soon after Sheikh Eisa's departure, Saudis began preparation for the Shah's arrival only to hear from the Iranian Foreign Minister, Ardeshir Zahedi, that Shah had decided to cancel his official visit to the kingdom. ${ }^{527}$ Shah's decision to cancel the visit was to protest Shaikh Eisa's visit, his reception as a head of state, and the language of the resulting communiqué. ${ }^{528}$ Dr. Abbas Ali Khal'atbary, the Iranian Undersecretary for Foreign Affairs, revealed to a correspondent from Christian Science Monitor, that the reason for the cancellation was that the Shah's visit to Saudi Arabia could have been interpreted as the Iranian "tacit approval" of the Saudi's recognition of Bahrain as an autonomous entity. ${ }^{529}$

The Iranian-Saudi rift was an opportunity for Egypt to pursue its revolutionary policies in the Persian Gulf region. Following the cancellation of the scheduled visit, $A l$ Ahram praised Saudi's strong and due support of the independence of the Persian Gulf sheikhdoms and the Arab character of "Gulf." The characterization of the Saudi-Bahraini talks and agreements by the Egyptian paper is interesting. Al-Ahram wrote:

An agreement had been reached between Saudi Arabia and Bahrain for the construction of the 12-mile bridge as part of the defense arrangements which the two countries will take after the withdrawal of British forces from

\footnotetext{
${ }^{525}$ Al Riyadh, 18 January 1968.

526 PRO/FO, 8/518/42, from Bahrain to London, 19 January 1968.

${ }^{527}$ SARCA: Telegram from the Saudi Embassy in Bangkok to the Foreign Ministry, 27 January 1968.

528 Al-Saud, Iran, Saudi Arabia. 33.

${ }^{529}$ Christian Science Monitor, March 16, 1968.
} 
the area before 1971. The bridge building aims at thwarting any attempt by Iran against Bahrain. ${ }^{530}$

Meanwhile, another disagreement flared up. Iran and Saudi Arabia had differences over offshore oil in the mid-Persian Gulf dating back to the early 1960s. In January, 1969, the two sides were exchanging accusations that their respective oil companies were drilling in the disputed waters. ${ }^{531}$ The two sides agreed on halting the drilling until a meeting could be held to negotiate the dispute. However, the arrangement collapsed when, on February 1, an Iranian gunboat drove an ARAMCO drilling rig - allegedly sent to drill in an offshore concession leased by Saudi Arabia to the oil company ${ }^{532}$ — out of the waters claimed by Iran. Apparently, Tehran had not ordered the seizure of the rig and the admiral in charge of the gunboat conducted the operation on his own discretion. King Faisal called the incident an "act of piracy." Even though, the US ambassador in Tehran was asked to mediate and ease the tension, Shah's order to release the rig put an end to further escalation of matter. This incident only added to the mistrust between the two states.

A third development in early 1968 brought territorial issues to the attention of the Iranian government. On January 22, the Ruler of Dubai, Sheikh Rashid Al-Maktoum, met with the Ruler of Abu Dhabi to discuss a federation of Arab emirates. Al-Maktoum had subsequent meetings with the rulers of Bahrain and Qatar regarding the matter. ${ }^{533}$ On February 18, Abu Dhabi and Dubai signed a union agreement, and a conference in Dubai brought the rulers of Bahrain, Qatar as well as those of the Trucial States to discuss the

\footnotetext{
${ }^{530}$ Al-Ahram, Feb. 3, 1968.

${ }^{531}$ SARCA: Telegram from King Faisal to Saudi Ambassador in Tehran, 29 January 1968.

${ }^{532}$ Middle East Economic Survey, Vol. XI, no. 43, 23 August 1968, 4.

533 The Times, 23 January 1968.
} 
idea. ${ }^{534}$ On February 27, the participants signed an agreement on the creation of a Supreme Council to coordinate a unified foreign and defense policy among them. Saudi Arabia and Kuwait welcomed the initiative; however, the inclusion of Bahrain, Sharjah and Ras alKhaimah in the document — which was only a declaration of intent — provoked the anger of the Iranian government. In response, on July 8, the Iranian Minister of Foreign Affairs released a communique asserting that "the creation of the so-called confederation of the Persian Gulf emirates embracing the Bahrain islands is absolutely unacceptable to Iran."${ }^{.535}$ In addition, on April 1, Iranian Minister of Foreign Affairs reiterated the official Iranian position by saying, "the British Government cannot bequeath to others territories that it has ... severed from Iran by force and trickery. The Imperial Government reserves all rights in the Persian Gulf and will in no circumstances tolerate this historical injustice and imposition. ${ } 536$

These three developments strained the Saudi-Iranian relations; however, Iran seemed willing to resolve the regional territorial issues with Saudi Arabia. An indication of such willingness was the Shah's remark on the importance of good relations with Saudi Arabia which “... could become the nucleus for stability and progress in the Persian Gulf." ${ }^{537}$ In spite of all the tensions, Shah viewed King Faisal as the only Arab leader who could balance Nasser, therefore, a resumption of amicable relations with Saudi Arabia was

\footnotetext{
534 Al-Saud, Iran, Saudi Arabia. 35.

${ }^{535}$ Kayhan International, July 9, 1969.

${ }^{536}$ SWB, Iranian statement on the Gulf, 2 April 1968.

${ }^{537}$ NSF: Telegram from Rusk to US Ambassador to Tehran (157), 28 February 1968, 'Iran Cables Vol. II, 66-69 [2 of 2],' box 136, Country File, Iran, LBJ Library.
} 
important for the Iranian government. Saudi Arabia demonstrated similar attitude with King Faisal telling Washington that he hoped the problems between the two countries could be managed through direct discussions. Secretary of State Dean Rusk in response asked Meyer, the US ambassador to Iran, to convey the King's opinion to the Shah.

The controversy over Bahrain entered an unprecedented phase with Iran beginning to signal fading lack of interest in the island as early as February $1968 .{ }^{538}$ In a meeting with the American national security advisor, Walt Rostow, the Shah said that he "... would not use force to gain Bahrain,” adding that, “... pearl and oil industries are no longer [a] great prize ... [and that the] island is infested with Arab nationalist trouble-makers." However, he stressed that Iran's old claim could not be dismissed without some honorable justification. ${ }^{539}$ In mid-March, the US ambassador to Iran proposed a formula for the Bahrain question. Concerned with the prospect of Shah's unilateral action which would have caused permanent feud across the Persian Gulf, Meyer argued that Shah could relinquish Iran's claim to Bahrain in exchange for Tunbs and Abu Musa islands. He also recommended that Bahrain stay out of the proposed Arab federation. ${ }^{540}$ The British, however, were opposed to the deal. ${ }^{541}$

In an interview with the Kuwaiti newspaper Al-Siyasah in early May, King Faisal publicly invited the Shah to pay a visit to Saudi Arabia. King Faisal assured Iran that no

\footnotetext{
${ }^{538}$ SARCA: Telegram from Saudi Ambassador in Tehran to King Faisal, 12 February 1968.

${ }^{539}$ NSF: Shah-Rostow meeting (62), 9 February 1968, 'Iran Cables Vol. II 66-69 [1 of 2],' box 136, Country File, Iran, LBJ Library.

${ }^{540}$ NSF: Telegram from US Ambassador in Tehran to Rusk (55), 15 March 1968, 'Iran Cables Vol. II 6669 [1 of 2],' box 136, Country File, Iran, LBJ Library.

${ }^{541}$ PRO/FO, 26/59510/167, from Tehran to London, 7 April 1968.
} 
Arab state in the region would take any action against Iran's interests. King Faisal's statement was received positively by the Iranian press and four days later the Shah responded by announcing that he would go to Saudi Arabia at the first opportunity. Following this exchange, Maroof Al-Dawalibi, an advisor to King Faisal, met with the Shah to discuss Iran's claim to Bahrain but much to his surprise, the Shah made a commitment to Saudi Arabia that he intended to drop the claim on Bahrain. On his way back, Dawalibi stopped in Manama to placate Bahrain's fears of Iranian intentions. ${ }^{542}$ The decision to inform the Saudi government of Iran's official position on Bahrain in May 1968 is a strong indication of the Saudi Arabia's weight in Shah's strategic decision. On June 3, 1968, Shah made a stopover in Jeddah on his way to Ethiopia. In this short symbolic visit, the two monarchs agreed upon a new date, in November, for the Shah to make a formal visit to Saudi Arabia. This time the visit took place on schedule between 9 to 14 November. This meeting gave special emphasis to the Palestine question, their rights and their claims. ${ }^{543}$ The atmosphere was friendlier than expected, with the Shah calling King Faisal "Amir al-Muminin." 544

With the promising prospect of a resolution to the dispute over Bahrain, the terms of a possible compromise over the Persian Gulf offshore oil began to emerge. In March, the president of ARAMCO, Thomas Barger, had presented a proposal for the resolution of

\footnotetext{
${ }^{542}$ Al-Saud, Iran, Saudi Arabia. 42.

${ }^{543}$ Iran Almanac and Book of Facts, 8th ed. (Echo of Iran, 1969) 216.

544 This is a highly respected title which was given to the early Caliphs and successors of the Prophet Muhammad. For a thorough discussion of the religious titles in Shiism refer to Jalal Matini, "Bahsi Darbare ye Sabeghe ye Tarikhi ye Alghab va Anavin e Olama Dar Mazhab e Shia," [A Historiography of Titles Used for Ulema in Shiism] Iran Nameh.
} 
the Saudi-Iranian oil dispute to the US government. Berger had suggested that a geographical or economic division of the disputed area might be the solution. At this stage, a response came from Washington that encapsulated the Johnson administration's attitude toward the Persian Gulf. The State Department believed that it would not be desirable to mention the Barger proposal to the Shah. Also in a memorandum, the State Department made it clear that the US should stay out of internal Gulf affairs [and suffice to] ... reminding both [Faisal and the Shah] that the best way to keep Nasser and the Russians out is to work together." $" 545$

On July 29, Iranian-Saudi negotiations on the Persian Gulf oil dispute were resumed in Taif, Saudi Arabia. The two states agreed in principle on equal division of "oil in place" and a new median line, a solution along the lines of Barger's recommendations. In order to conclude the agreement, King Faisal sent Muhammad Zaki Yamani, Saudi Minister of Oil and Petroleum, to Tehran in August, hoping that the two states could move on from the dispute and instead "... focus on other essential matters." ${ }^{546}$ When Yamani arrived for the talks, the Iranian negotiators had changed their position, arguing for a division of "recoverable oil" or proven oil reserves and not the "oil in place." 547 Yamani objected to the proposal, citing technical difficulties. The negotiation deadlock was overcome when Yamani met with the Shah, the day after. Aware of the Saudis' stronger legal case and the

\footnotetext{
545 NSF: Memorandum from Foster to Rostow (222), 21 May 1968, 'Iran memos Vol. II 66-69,' box 136, Country File, Iran, LBJ Library.

${ }^{546}$ SARCA: Letter from King Faisal to the Shah, 16 August 1968.

${ }^{547}$ SARCA: A technical definition of 'oil reserves' is 'estimated quantities of all liquids defined as crude oil, which geological and engineering data demonstrated with reasonable certainty to be recoverable in future years from known reservoirs under existing economic and operating conditions,' While the 'oil in place' can be defined as 'the amount of crude oil that is estimated to exist in a reservoir and that has not been produced. See Energy Information Administration/International Energy Annual (1993)
} 
need for preserving the stability in Saudi-Iranian relations, Shah endorsed the mutual understanding reached in Taif. ${ }^{548}$

On the federation, the Shah clarified his position in an interview in May with the Kuwaiti journal Al-Ra'y al-Amm. In this interview, Shah expressed that he had no opposition to the formation of the Arab federation, “... as long as historical and territorial rights are observed in its foundation." Shah expressed his concern that "the federation could inherit the old British colonial policy, which opposes the interests of Iran." ${ }^{549}$ Tehran Radio continued to speak of the federation as an unacceptable British plot to maintain its imperialist policy. ${ }^{550}$ In spite of the concerns expressed by the Iranian government, a meeting of Persian Gulf rulers was eventually convened on July 8 and an agreement on the functions of federal institutions was issued. ${ }^{551}$ Iranian Foreign Minister opposed to the results of the convention, referred to the federation as a "manifestation of colonialism," and indicated that the inclusion of Bahrain in the federation was unacceptable. ${ }^{552}$ Iranian government's rhetoric against the federation, however, was never paired with any subversive attempt. In fact, in spite of a hardline rhetoric toward these developments in the Persian Gulf region, ${ }^{553}$ demonstrations throughout Iran in support of the claim to Bahrain, ${ }^{554}$ and the Iranian press protesting any insinuations of independent Bahraini

\footnotetext{
${ }^{548}$ SARCA: Telegram from Saudi Ambassador in Tehran to Foreign Ministry, 19 August 1968.

${ }^{549}$ FBIS, Tehran, Kayhan International in English, 10 May 1968.

${ }^{550}$ SWB, Tehran Home Service in Persian, 27 May 1968.

${ }^{551}$ SWB, Kuwait Home Service in Arabic, 7 July 1968.

${ }^{552}$ SWB, Tehran Home Service, 8 July 1968.

${ }^{553}$ See for example New York Times, 17 September 1968.

554 The Times, 8 August 1968.
} 
sovereignty by outsiders ${ }^{555}$ a private deal on Bahrain was being prepared. The United States continued with its policy of refraining from any involvement in the region's disputes, allowing the British to take the lead. ${ }^{556}$

On November 9, 1968, Shah paid his promised state visit to Saudi Arabia. The speculations prior the visit dwelt on discussion on Bahrain, Hormuz islands, and the Federation of Arab Emirates between the two kings; $;{ }^{557}$ however, the joint communique issued at the end of the meeting made no reference to the Persian Gulf territorial disputes. Interestingly, the Western press, unlike their Iranian counterparts, reported that the Shah, in his meeting with King Faisal, had dropped the Iranian claim on Bahrain. ${ }^{558}$

At the press conference in New Delhi, on January 4, 1969, Shah announced that Iran was not willing to use force to regain what rightfully belonged to it rather "it [preferred] to see the Bahraini people make their own free choice." ${ }^{559}$ This statement was promising to the settlement of Arab-Iranian dispute; however, the procedural difficulties remained in place. Throughout 1969 and the early 1970, a tripartite approach led by Iranian, British and the United Nations officials sought practical ways to implement the Shah's commitment to resolving the Bahrain question. In May 1970, trying to normalize relations with Bahrain, Iran sent to Bahrain a mission led by the Foreign Ministry's political under-

\footnotetext{
555 See for example Ettela 'at, 24 July 1968.

${ }^{556}$ NSF: Telegram from Rusk to US Ambassador in Tehran (136), 2 August 1968, 'Iran Cables Vol. II 6669 [2 of 2],' box 136, Country File, Iran, LBJ Library.

${ }^{557}$ SARCA: Telegram from Saudi Ambassador in Tehran to King Faisal, 18 October 1968.

${ }^{558}$ Compare The Times, 15 November 1968 with Ettela 'at, 13 November 1968.

${ }^{559}$ FBIS, Tehran Domestic Service in Persian, 14 January 1969.
} 
secretary, Manuchehr Zelli. ${ }^{560}$ This visit was an indication of Iran's willingness to eventually bring the dispute over Bahrain to a peaceful end. ${ }^{561}$ On March 29, 1970, Ardeshir Zahedi, the Minister of Foreign Affairs, addressed the nation's representatives in an attempt to justify the decision on Bahrain. An excerpt of his address follows:

I want to use the opportunity to brief you on the government's attempts in recent months to bring the issue of Bahrain to a legal and acceptable settlement. The separation of Bahrain from Iran was a British imperialist plot and for the past 150 years, Britain has prevented the annexation of Bahrain to the Iranian territory. During this period, Iran never dropped its legitimate claim over Bahrain. In fact, Iran has tried any possible bilateral relations and international channels to defend and preserve its legal rights in Bahrain. Iran exhausted all possibilities offered by the League of Nations and then the United Nations; however, the controversy persisted. We are about to enter a new era and the future of the Persian Gulf necessitates the resolution of the issue once and for all. In 1971, Britain will leave the Persian Gulf, meaning that we can use our army to capture the island; however, we need to bear in mind that Bahrain's demographic composition might have gone through an immense change throughout all these years. The inhabitants of Bahrain might hold wishes that we are not aware of. Accordingly, Shahanshah Aryamehr has wisely decided to appeal to the Iranian aversion to the use of force for conquest. We will not use force to regain Bahrain against the will of its inhabitants. Shahanshah believes that there is no merit in the conquest of a territory whose people are against us. In this pursuit, we have decided to assign the United Nations, the sole arbiter of international disputes, to conduct a survey of the will and wishes of the Bahraini inhabitants. We believe that this approach will help the royal government in the attainment of its sublime objectives being the preservation of security and stability in the region. ${ }^{562}$

The great powers, despite their interests in the outcome of regional disputes in these years, played only a secondary role in resolving these issues. In fact, progress in the disputes resolution seemed to occur when Iran took diplomatic initiatives at a regional and/or a bilateral level. Of course, the British and American initiatives came to assist Iran

\footnotetext{
${ }^{560}$ FBIS, Tehran Domestic Service in Persian, 23 May 1970.

${ }^{561}$ SWB, Tehran Home Service in Persian, 3 April 1970.

${ }^{562}$ Doc. No. 9. 1349-54-98-1056. The Selection of the Persian Gulf Documents
} 
after the Shah had agreed on a particular course of action. Considering the permissive geopolitical context of the region in this decade resulting from pending British withdrawal and unwillingness of the United States to intervene excessively in regional affairs, Iran, relying on its unique military might in the region, could have determined the outcome of events unilaterally; however, contrary to its public statements, Iran did not pursue its interests without reference to neighboring states. In particular, Iran was interested in maintaining normalcy in its relations with Saudi Arabia.

This attempt on the part of Iran did not go unnoticed, and was reciprocated by Saudi Arabia. The pinnacle of these mutual efforts was the 1969 meeting between King Faisal and the Shah in the Moroccan capital, Rabat. The occasion was the first Islamic Summit and the celebration of the establishment of the Organization of the Islamic Conference (OIC). The Shah and King Faisal entered together and received a standing ovation from an audience that included kings and presidents of the Islamic world. This positive initiative and the ability to overcome setbacks set the stage for continued constructive political relations between Saudi Arabia and Iran during the 1970s.

\section{Iranian-Saudi Coordination Against Iraqi Seizure of Kuwaiti Outposts}

The regional equilibrium created as the result of the roles Iran and Saudi Arabia were assigned by the Nixon Doctrine and the benefits they had received for acting as the US surrogates in the region effectively deterred ambitious, and revisionist policies in the region for a whole decade. The containment of Iraq's expansionary appetite for Kuwait in this period is arguably the most important achievement of the alignment between Iran and Saudi Arabia at the regional level. Iraq during the military regime of General Abdel-Karim 
Qasim had rhetorically claimed that Kuwait was part of the southern Basra province in Iraq. After the Ba'thist coup in February 1963, this rhetoric became stronger and in 1973 turned into an offensive action when Iraq — bolstered by the 1972 friendship treaty with the Soviet Union - occupied Kuwaiti border outposts and demanded control over the Kuwaiti islands of Warba and Bubiyan. The fact that Iraq retreated from its position and did not attack Kuwait at that stage was for the support and assurance that Kuwait received from Saudi Arabia and Iran. ${ }^{563}$ Another account by Naddav Safran attributes Iraqi withdrawal to the prospect of Iranian-Saudi joint retaliatory measures. ${ }^{564}$ For the rest of the decade, Iraq succumbed to the regional order normatively buttressed by the tacit alignment of roles and policies between Iran and Saudi Arabia. In compliance to that order, Iraq consented to delineate the Shatt al-Arab according to Iranian demands stipulated in the 1975 Algiers Agreement. Aware of the military disparity between Iraq and the two regional powerhouses, and the fact that the revolutionary Arab socialist ideology espoused by the Ba'thist regime had no appeal to the monarchies of the Persian Gulf, ${ }^{565}$ Iraq acquiesced to the regional order and never tried to upset the Saudi-Iranian lead. ${ }^{566}$

This regional consensus was unachievable without the permissive/encouraging context that resulted from the Twin Pillars doctrine of Nixon administration. Richard

\footnotetext{
563 John Duke Anthony, "The Persian Gulf in Regional and International Politics: the Arab Side of the Gulf," in Hossein Amirsadeghi (ed.), The Security of the Persian Gulf (London, Croom Helm, 1981), 170196.

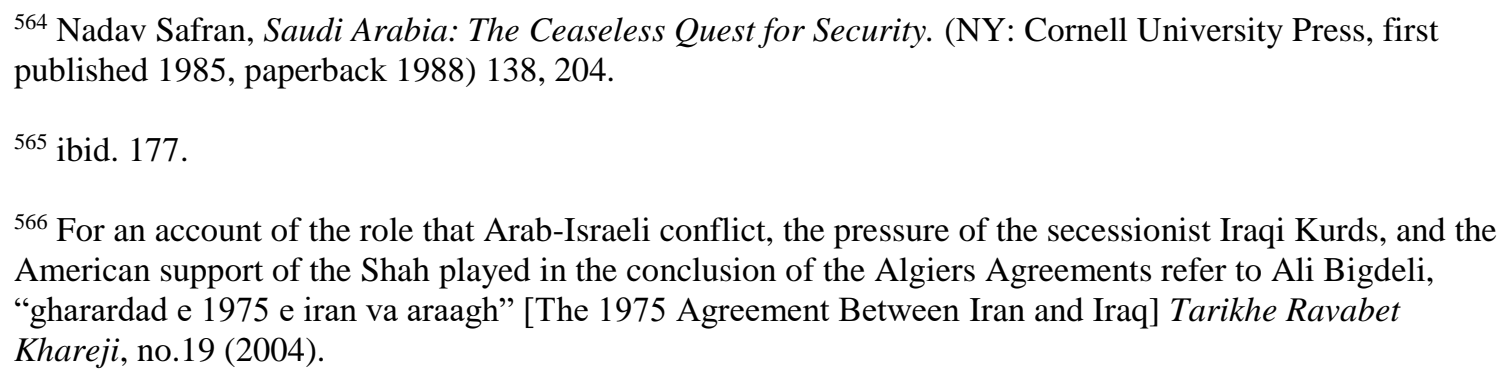
American support of the Shah played in the conclusion of the Algiers Agreements refer to Ali Bigdeli, "gharardad e 1975 e iran va araagh" [The 1975 Agreement Between Iran and Iraq] Tarikhe Ravabet Khareji, no.19 (2004). 
Haass ${ }^{567}$ finds the "large degree of commonality of interests and purpose" between Iran and Saudi Arabia in the 1970s impressive. He believes that despite all differences between the two states over oil policies, Iran and Saudi Arabia helped OPEC survive a rough period of massive changes in the international oil economy. "Massive importation of arms and mutual military development did not bring about deep hostility or conflict between the two countries," and "the absence of formal machinery for the promotion of regional security did not preclude coordination and tacit cooperation," Haass continues. ${ }^{568}$ However, Richard Hass's analysis might not capture the whole truth of the Iranian-Saudi cooperation in the aftermath of Yom Kippur War, this time against the American interests.

\section{Yom Kippur/Ramadan War and Oil Embargo}

While Saudis had managed to stay out of 1948 war that led to the creation of Israel and then again 1956 Suez crisis, the 1967 war "upset the territorial and psychological balance of the Arab world" to the extent that Saudis were dragged to the central stage of the struggle between Arabs and Israelis. With Israelis attaining the control of Jerusalem, the third holiest site in Islam, Saudis — self-proclaiming guardian of Islam — had to assume a strong stance against Israel in the name of Islam. King Faisal's primary concern with this circumstance was more political than religious. The real anxiety for the Saudis was the undesirable outcome of strengthening Arab radicalism in the region in response to the Arab-Israeli struggle. This anxiety was predicated on the experience Saudis had in the

\footnotetext{
${ }^{567}$ Richard Hass was the special assistant to the deputy under Secretary of Defense during the period of Iranian revolution.

${ }^{568}$ Richard Haass, "Saudi Arabia and Iran: The Twin Pillars in Revolutionary Times," in Hossein Amirsadeghi (ed.), The Security of the Persian Gulf (London: Croom Helm, 1981), 163.
} 
1950s and 1960s when the radical regimes targeted Saudi Arabia by a series of sabotage bombing. The Saudis' apprehension was exacerbated by the political leadership vacuum created as the result of the Six Day War. This was an opportunity for the Palestinians to emerge and declare "vengeance on Arab regimes tepid in support of their cause." This fear was warranted as Saudi Arabia was a special and easy target for Palestinians. On May 30, 1969, a section of the Tapline that carried a huge amount of oil a year to Mediterranean ports was allegedly blown up by the Popular Front for the Liberation of Palestine, giving more credence to the Saudis' threat perception. Saudis' apprehension of the Palestinian vengeance was further corroborated by the publicity PLO's acts of sabotage and massacre around the world received. ${ }^{569}$

The Israeli stunning victory against a coalition of Arab states in 1967 was humiliating and demoralizing for the Arab world. Although, the Johnson administration catalyzed the ceasefire process, but later in November 1967, accepted the British initiative which led to the United Nations Security Council Resolution 242. This resolution provided for the permanency of the Jewish state, yet did not succeed in putting an end to hostilities. ${ }^{570}$ After Nasser died in September 28, 1970, Anwar Sadat succeeded him. The Egyptian succession coincided with the overthrow of Shukri al-Quwatli's rule in Syria by Hafez al-Asad. These two leaders entered an alliance leading to the 1973 Yom Kippur War. On October 6, 1973, Egypt and Syria launched an attack on Israeli-occupied territory, attempting to push back Israel from the Sinai and Golan Heights. With the

\footnotetext{
569 Sandra Mackey, The Saudis: Inside the Desert Kingdom, (Boston, Houghton Mifflin Company, 1987) 320-321.

${ }^{570}$ Kechichian, Faysal, 147.
} 
element of surprise, the Egyptian-Syrian alliance made impressive advances. Once the Israeli forces recovered the surprising attack, they managed to outmaneuver the Arabs. Yet again, Israel was victorious but at very high cost and casualties.

In response to the American involvement in the Yom Kippur War, OAPEC announced a crippling oil embargo against Canada, Japan, the Netherlands, the United Kingdom and the United States. As much as Saudis were concerned, this move was a dissent from Saudi government rhetoric that the kingdom would not utilize its oil resource as a weapon in Arab-Israeli conflict. ${ }^{571}$ In fact, as late as July 1972, King Faisal had categorically opposed the idea of weaponizing oil against the United States:

I recall that such a suggestion was made by some at Rabat Conference, but it was opposed by Gamal Abdul Naser on the grounds that it would affect the economies of the Arab countries and interfere with their ability to support Arab staying power; at the same such a measure would not affect America because America does not need any of our oil or other Arab Gulf oil before 1985. Therefore, my opinion is that this proposal should be ruled out, and I see no benefit in reviving its discussion at this point. ${ }^{572}$

With a shift in rhetoric, King Faisal warned the United States in August that "he [could] not continue to maintain the shipment of oil if the United States continued its cordial relations with Israel," ${ }^{, 573}$ but neither Europe nor America took King Faisal's warning seriously. ${ }^{574}$ At first, Saudi Arabia did not spearhead the drive for the oil embargo, and delayed its commitment to the initiative with the hope to ride out conflict without

\footnotetext{
${ }^{571}$ Madawi Al-Rasheed, A history of Saudi Arabia. (Cambridge University Press, 2010) 131.

572 John A. Shaw \& David E. Long. Saudi Arabian modernization: the impact of change on stability. (Praeger Publishers, 1982) 9.

${ }^{573}$ Benson L. Grayson, Saudi-American Relations, (Washington: University Press of America, 1982) 110.

${ }^{574}$ Malcom C. Peck, “The Saudi-American Relationship and King Faisal.” in Willard A. Beling (ed.), King Faisal and the Modernisation of Saudi Arabia, (London: Croom Helm, 1980) 240.
} 
having to play the oil card. ${ }^{575}$ Ultimately, Saudi Arabia acquiesced to the pressures and responded to the call by the Palestinian Liberation Organization urging oil-producing Arab states to weaponize their oil wealth. ${ }^{576}$ This was an interesting development which could be explained by rhetorical attachment of Saudi Arabia to Arab solidarism, not to mention that the conservative Saudi society and its delicate stability warranted such a pragmatist move. $^{577}$

Subsequently, ten Arab oil ministers met in Kuwait on October 17 and agreed to reduce oil production by five per cent every month until the Middle East conflict was resolved. They also agreed to raise oil prices by 17 per cent which came on top of 11.9 percent price increase by OPEC in July. A day after, Saudi Arabia went a step further by announcing a ten per cent reduction in oil production, with a complete ban on petroleum shipment to the United States. ${ }^{578}$ Riyadh declared that it would cease oil supplies to all countries that had adopted a pro-Israeli stance. ${ }^{579}$

Saudi Arabia initially delayed the full enforcement of the embargo in order to avoid further antagonizing the United States, ${ }^{580}$ but once the embargo was fully enforced, the 70 percent rise in oil prices shocked the international community. ${ }^{581}$ The crisis caused by the

\footnotetext{
575 David B. Golub, When Oil and Politics Mix: Saudi Oil Policy, 1973-1985. No. 4. (Harvard University Center Middle Eastern, 1985) 10.

${ }^{576}$ Grayson, Saudi-American Relations, 15.

577 Simon W. Murden, "Secondary Institutions of Regional Interstate Society," in Barry Buzan and Ana Gonzalez-Palaez (ed.), International Society and the Middle East: English School Theory at the Regional Level, (Palgrave Macmillan UK, 2009) 125.

${ }^{578}$ Grayson, Saudi-American Relations. 110-111.

${ }^{579}$ Vassiliev, The History of Saudi Arabia, 393.

${ }^{580}$ Golub, When Oil and Politics Mix, 112.

${ }^{581}$ Safran, Saudi Arabia, 161.
} 
oil embargo created a major rift within NATO in the height of the Cold War. Some European nations and Japan sought to disassociate themselves from the United States foreign policy in the Middle East to avoid being targeted by the boycott. To address the crisis, the Nixon Administration began multilateral negotiations with the combatants. They arranged for Israel to pull back from the Sinai Peninsula and the Golan Heights. The promise of a negotiated settlement between Israel and Syria was enough to convince Arab oil producers to lift the embargo in March 1974. The embargo occurred at a time of rising petroleum consumption by industrialized countries and coincided with a sharp increase in oil imports by the world's largest oil consumer, the United States.

The Saudi decision to use the oil weapon played a key role in "catapult[ing] Saudi Arabia to the center of Arab politics after the 1973 war." ${ }^{, 52}$ Saudi Arabia's image in the Muslim and Arab world was altered beyond recognition. Faisal and Saudi Arabia became symbols of defiance in the eyes of many Muslims. The oil embargo "underscored the Kingdom's pivotal position within oil producing countries, brought it into open confrontation with the United States for the first time, and thrust upon it an unprecedented leadership role in the Arab World." ${ }^{583}$ Furthermore, Saudi Arabia became the critical player in international oil diplomacy. ${ }^{584}$ Domestically, the dramatic increase in oil prices brought Saudi Arabia an unprecedented affluence, which helped facilitate King Faisal's modernization projects which had started in the late 1960s, strengthen the ability of the

\footnotetext{
${ }^{582}$ Cary Fraser, “In Defense of Allah's Realm: Religion and Statecraft in Saudi Foreign Policy Strategy,” in Susanne H. Rudolf and James Piscatori (eds.), Transnational Religion and Fading States, (Boulder: Westview, 1997) 222.

583 Safran, Saudi Arabia, 176.

584 Fraser, “In Defense of Allah’s Realm,” 222.
} 
regime to extend services, and enforce state control over the population. ${ }^{585}$ The dramatic increase in oil revenues allowed Faisal to launch his economic transformation and increase his government spending on infrastructure. From 1972 through 1973, Saudi GDP rose from 40.5 billion to an unprecedented level of 99.3 billion Riyals. ${ }^{586}$ Due to an increase in oil revenues and Faisal's management of such unprecedented affluence, his reign is recalled in popular imagination as Al-Nahda which means renaissance. Faisal expanded education and health services, improved transportation and communication facilities, implemented bedouin sedentarization schemes and, most importantly, enhanced Saudi military capabilities. $^{587}$

Initially, the OAPEC initiative excluded Iran, perhaps due to the Shah's decision to maintain relations with Israel. In November, Prince Fahd made a visit to the Shah of Iran. The aim of the visit was to get Iran onboard with the embargo but the Shah — committed to project neutrality — refused to oblige. ${ }^{588}$ Shah was determined to keep neutrality and by doing so solidify Iran's position in the region by balancing Iran's relations between the warring factions, the policy that disappointed Israel as well. ${ }^{589}$ However, trying to balance his position, Shah agreed to help the Arab front with medical aid and providing crude oil to Egypt. ${ }^{590}$ Interestingly, after the war, Iran provided oil to US military bases and aided

\footnotetext{
585 Al-Rasheed,.A history of Saudi Arabia. 130.

586 International Monetary Fund (IMF) International Statistics Yearbook, (Washington) 798.

587 Al-Rasheed,.A history of Saudi Arabia. 133.

588 Alikhani, the Diaries, 233-234, 260.

589 Parsi, Treacherous alliance, 49.

${ }^{590}$ Charles Glaser and Rosemary Kelanic, Crude Strategy, (Washington D.C. Georgetown University Press, 2016) 33.
} 
US peacemaking efforts by selling oil to Israel making it easier to return oil-rich portions of Sinai Peninsula to Egypt. Shah was critical of the OAPEC embargo. He believed that "playing with the oil weapon is extremely dangerous." He recommended that the Arabs "drop the embargo because it [was] depriv[ing] the world of... something vital."591

Despite repudiating the oil embargo, Shah had signaled in November that he advocates the rise in oil prices. In an interview with Oriana Falacci, the Shah of Iran protesting the strategy by the West to buy crude oil and sell it back in other forms at much higher prices — said, "Of course [the price of oil] is going to rise." ${ }^{, 52}$ In December 1973, with the Arab embargo still in place, the Shah used his influence in OPEC to impose a drastic increase in OPEC's posted price from 5.11 per barrel to $11.65,{ }^{593}$ making a remarkable case of policy convergence between Iran and Saudi Arabia in that decade. This convergence of policies was strained and tainted as soon as the United States employed its clout on the Saudis.

Once approached and influenced by the United States, Saudis began to protest the latest oil price hike, even though it meant massive influx of oil revenue into the Saudi economy. As soon as, the US Secretary of the Treasury, George Shultz called for the reduction of oil prices and specifically mentioning the 5-dollar price tag as "just," Saudi officials reverberated the same concerns and figures. In an interview, Shaykh Ahmad Zaki Yamani said, "the oil price hike in the Persian Gulf region should be logical not as to

\footnotetext{
${ }^{591}$ New York Times, 22 Dec. 1973.

${ }^{592}$ New York Times, 12 Dec. 1973.

${ }^{593}$ Andrew S. Cooper The oil kings: how the US, Iran, and Saudi Arabia changed the balance of power in the Middle East. (Simon and Schuster, 2012) 143-147; See also Alikhani, The Diaries, 190-205.
} 
destroy the economy of the consuming nations." ${ }^{994}$ The Shah of Iran, nevertheless, was steadfast and stood by his decision adamantly. He said:

What is a just price of oil? US Secretary of Treasure, George Shultz has apparently no doubt about the answer. He has come out with a call for the reduction of oil prices, mentioning the figure of 5 dollars per barrel of crude. Shultz is entitled to his opinion just like everyone else. But the whole thing cannot stop there. If the consuming countries were to be allowed to arrogate to themselves the right to dictate oil prices to OPEC members, some measures of reciprocity would, no doubt, be justified. Would Secretary Shultz or any of his counterparts in the OECD countries allow us to decide prices of their goods? Incidentally, the magical figure of $\$ 5$ reportedly mentioned by Shultz does not seem to have emerged out of thin air. Where did it come from? What analysis is it based on? But what is especially interesting is that Saudi Arabia's oil minister is reported to have mentioned the same figure in some of his discourses recently. The Shaykh has made no secret about his opposition to the price decided by OPEC in Tehran. He is a 5-dollar-a-barrel man. Who inspired who? It would be interesting to know. That the Shaykh and Shultz are on the same wavelength cannot be accidental unless we believe in the telepathy of love. ${ }^{595}$

In this period, aside from abovementioned differences, close but not necessarily deliberate Iranian-Saudi relations transformed OPEC into an effective international cartel with huge leverage on the direction of the world economy. ${ }^{596}$ According to Kissinger, such alignment of policies between Iran and Saudi Arabia with such massive repercussions could not have been achieved outside the permissive context of the Twin-Pillars Doctrine. ${ }^{597}$ Ironically, however, the resulting recession caused by Iranian-Saudi involvement in the oil embargo did not cause the unraveling of the twin-pillars strategy. If anything, the strategic value of oil increased the desire of the US to maintain its geopolitical

\footnotetext{
594 “Commentary on Saudi Oil Price Stand,” Tehran Domestic Service, Jan 28, 1974 translated and published in FBIS-MEA-74-021. Jan 30, 1974.

${ }^{595}$ Kayhan International, (Tehran, 22 Jan, 1974).

596 Pirouz Mojtahed-Zadeh, "Regional Alliance in the Persian Gulf: Past Trends and Future Prospects." Iranian Journal of International Affairs 10 (1998): 1-20.

${ }^{597}$ Henry Kissinger, Years of Upheaval, (London: Weidenfeld and Nicolson, 1982) 882.
} 
presence in the region and this ironically served to strengthen the commitment of the US towards Persian Gulf security.

Even though the cooperative norms propagated by the Nixon Doctrine contributed to the alignment of policies between Iran and Saudi Arabia, it is important to avoid exaggerating the role this permissive context bore. Such a bold and unprecedented move by the pro-American governments in Tehran and Riyadh against the United States interests in the height of the Cold War cannot be discounted to the continuation of Iranian-Saudi rapprochement beginning in the mid-1960s. In other words, the alignment of policies between Iran and Saudi Arabia in this decade was neither encouraged by a sudden outburst of pan-Islamist consciousness, nor created by the identical task of guaranteeing the statusquo assigned to Iran and Saudi Arabia.

The core to such a coincidental alignment of policies in 1973 was a pragmatic turn by the rulers in both countries in response to a host of threats to their rules. The rulers in both states found maneuvering around the global Islamic sentiments to the best of their interests, as both faced a host of growing domestic pressures on the state. Shah in Iran was pressured by a resurgent indigenous Islamic political culture, and King Faisal was challenged by the spread of Islamism, Ba'thist and Nasserite versions of Arab nationalism. ${ }^{598}$ Both states pragmatically used the opportunity of rallying around the cause of the Palestinians, even at the cost of alienating the United States, in order to make a gesture in response to the challenges they were facing. The tone and language that Shah employed in an interview with Al-Ahram on January 30, 1974 are telling. The Shah reiterated his position by saying:

${ }^{598}$ See Adib-Moghaddam, The international politics of the Persian Gulf. 13. 
Following the war between the Arabs and Israelis, it became clear to what extent the enemy [emphasis added] was taken by surprise, and the world also understood that the previous situation could not continue, because no country is prepared to accept the continued occupation of its territories. Our views ... are unalterable, and it is our opinion that Israel should evacuate the Arab territories on the basis of the UN resolutions of 1967. We reject the occupation of territories by the use of force. ${ }^{599}$

These precautionary measures by the Iranian and Saudi rulers, nevertheless, brought the two states an unprecedented amount of wealth and influence.

Prior the oil embargo, King Faisal had been rhetorically promoting Saudi Arabia as guardian of Islam and supporter of Muslim causes. The 1973 Saudi Arabia's weaponization of its' only vital resource for the Palestinian cause enhanced Saudi Arabia's Islamic credentials and influence in the Arab world, even though King Faisal was reluctant to be lumped with the hardline Arab forces in the Israeli-Arab conflict. Not only did this unfortunate circumstance conflict with the Saudi Arabia's need for maintaining its special relationship with the United States, but also the massive wealth and political influence that Saudi Arabia garnered in this period brought about other complications for the Saudi regime. Saudi Arabia moved to the center of regional developments at the height of the Cold War, exposing more than ever the vulnerability of the Saudi regime and the structural difficulties that prevented Saudi Arabia to provide for its own security. The solution, the Saudi leadership believed, was the continuous and unabated US protective patronage against internal and external threats. Saudi sovereignty over the holiest Islamic sites made

\footnotetext{
599 Al-Ahram interviews the Shah on the Mid-East Developments, Tehran Domestic Service, January 30 , 1974. FBIS-MEA-74-022, January 31, 1974.
} 
this partnership problematic, ${ }^{600}$ with repercussions that would emerge in the following decades, specifically in Iranian-Saudi relations after the 1979 revolution.

\section{Iran-Iraq Border Dispute/ 1975 Algiers Agreement}

With the 1968 Iraqi revolution and the developments emerging in its aftermath, attempts were made to settle the outstanding disputes with Iran. An official Iranian delegation arrived in Baghdad in February 1969 to negotiate a new protocol for an alternative treaty to that of 1937; however, the proposal was turned down by the defiant Iraqi side. In response, Iran resumed navigation in the disputed zones of Shatt al-Arab. This measure had the Iraqi government summon the Iranian ambassador to hand him a letter of protest which the ambassador found threatening and insulting to Iran's honor and sovereignty. This resulted in the unilateral cancellation by the Iranian government of the Boundary treaty of 1937 . Iranian government took on provocative measures and began to deploy troops along the length of the entire boundary with Iraq. Iranian vessels continued to navigate Shatt al-Arab with the protection by Iranian gunboats and warplanes flying overhead in violation of the established laws. ${ }^{601}$ With the intensification of propaganda war, relations between the two states reached crisis proportions.

Tensions in Iraqi-Iranian relations continued especially with the Iraqi stance on Iranian occupation of the three Persian Gulf islands at the end of 1971. The Iraqi government severed diplomatic relations with Iran and filed, along with Libya, Algeria and

\footnotetext{
${ }^{600}$ Al-Rasheed,.A history of Saudi Arabia. 130.

${ }^{601}$ Sayyar al-Jamil, "Iraqi-Iranian Boundary and territorial disputes," in Khair el-Din Haseeb, Arab-Iranian Relations (Beirut, Center for Arab Studies) 270.
} 
South Yemen, a joint complaint to the United Nations Security Council against Iran's "expansionist" measures in the region. The situation remained volatile with border clashes in 1974 bringing the two countries on the brink of full-fledged confrontation. ${ }^{602}$ These clashes received widespread coverage around the world. ${ }^{603}$ As the matter grew in gravity, the Iranian security language shifted dramatically within few days. While on February 13, 1974, the Iranian government had announced following the border skirmishes that "Iran [did] not look any opportunity as an opportunity for aggression, because a peace-loving Iran exert[ed] all its efforts to eliminate tension and expose policies implemented by proxy in the region, ${ }^{, 604}$ on February 16, in a commentary on Iraqi aggression, the Iranian government asserted that "as a responsible country which has undertaken to preserve peace, Iran does not reply to aggression with aggression but by crushing the attacking troops. ${ }^{\circ 605}$

For so long, Iraq was preoccupied by Iran's destabilizing support of Iraqi Kurdish resistance. Therefore, a settlement of the Iranian support for the Iraqi Kurds could possibly be part of a resolution to Iranian-Iraqi territorial disputes. With that in mind, in September 1974, Saudi intelligence chief Kamal Adham along with a prominent Saudi prince representing King Faisal, and Egyptian representative Muhammad Ashraf Marwan, traveled to Tehran to explore ways to resolve the Iran-Iraq border dispute and control the regional arms race. The Shah believed the Egyptian-Saudi efforts would fail to bring Iraq

\footnotetext{
${ }^{602}$ See FBIS-MEA-74-029 (Feb. 11, 1974); Mohamed Hassanein Heikal, The Ayatollah's Guns: The Story of Iran and the Revolution (Beirut: Dar al-Shorouq, 1982) 137.

${ }^{603}$ See FBIS-MEA-74-032 (Feb. 12, 1974).

${ }^{604}$ See FBIS-MEA-74-032 (Feb. 13, 1974).

${ }^{605}$ See FBIS-MEA-74-034 (Feb. 16, 1974).
} 
out of the Soviet fold. Yet, he agreed to halt support for Iraqi Kurds in return for a resolution of the dispute with Iraq over the Shatt al-Arab.

During the OPEC summit conference in Algiers in March 1975, Algerian President Hawari Boumediene initiated a historical initiative for resolving Iranian-Iraqi disputes built upon the tacit approval that the Shah gave to Saudi-Egyptian representatives regarding Iranian support for the Iraqi Kurds. On March 6, 1975, he managed to get Saddam Hussein and the Shah to sign the Algiers Agreements. The agreement was predicated on the principle of good neighborliness and implementation of the principles of the inviolability of national soil, common borders and non-interference in the internal affairs of both sides. Regarding the Shatt al-Arab dispute, per the stipulation of the Algiers Agreement, the waterway was demarcated according to the Thalweg line. ${ }^{606}$ Such demarcation of the water boundary between the two states granted Iran the better portion of the disputed waterway.

Algiers Treaty revived the traditional bonds between Iran and Iraq. These bonds with the mediatory efforts that Saudi Arabia brought to the resolution of the Iranian-Iraqi territorial disputes strengthened, in Washington's view, the prospect of a collective regional security arrangement around the Iranian axis, but neither Saudi Arabia nor Iraq were willing to concede the central role to Iran. The Algiers Treaty would certainly have been a genuine historical step toward ending the prevailing problems and the ancient disputes between the two neighbors. The two states could have enjoyed the solid foundation that the treaty offered for cooperation and mutual understanding to spread

\footnotetext{
${ }^{606}$ Hamid Ahmadi, ravabet iran va arabestan dar sadeh bistom: doreh pahlavi [Relations between Iran and Saudi Arabia in the Twentieth Century: Pahlavi Era]. (Tehran: markaz chap va entesharat vezarat oumur kharejeh, 2007) 230-231.
} 
bilateral relations; however, the revolutionary climate in Iran precluded further development of those ties.

\section{Iranian-Saudi Relations during King Khalid Reign}

On March 25, 1975, King Faisal was assassinated by his half-brother's son. In a historical move, Iran declared a week of mourning and the Shah paid a visit to the Kingdom on 28-29 April 1975 to extend his condolences to the new Saudi monarch, King Khalid. The two monarchs conducted fruitful discussions regarding bilateral matters, international issues and matters of concern to the whole Islamic world. The two countries also agreed that the security and stability of the Middle East could not be obtained without Israel's withdrawal from all Arab territories and the restoration of Palestinian rights. At the end of his visit, the Shah extended an invitation to King Khalid to visit Iran. ${ }^{607}$ Below, major characteristics and hallmarks of King Khalid's reign are presented.

\section{Hallmarks of King Khalid Reign}

After ascending to the throne, King Khalid named his half-brother, Fahd as Crown Prince. Soon after the appointment, Crown Prince Fahd assumed most of the typical decision-making responsibilities of a King while King Khalid was more a ceremonial figure due to his deteriorating health. ${ }^{608}$ Even though such division of tasks between the king and the crown prince might be reminiscent of King Saud's period of reign, the Saudi ruling family did not go through any infighting in this period. Indeed, the politics of ruling

\footnotetext{
${ }^{607}$ Arab News, 30 April, 1975.

${ }^{608}$ Al-Rasheed,.A history of Saudi Arabia. 143.
} 
family during King Khalid reign enjoyed the stability that King Faisal's institutionalized division of tasks and ministerial jobs among senior princes had brought to the Saudi court. It was in this period that the so-called Sudairi Seven ${ }^{609}$ became more consolidated as a political force among the Saudi ruling group.

Despite relative stability in the court of Al-Saud, King Khalid's period of reign (1975-1988) was raucous. In this period, the contradiction between Saudi Arabia's Islamic rhetoric and increasing materialist tendencies within the Saudi society began to unfold and paved the way for the return of the Ikhwan. While Islamic worldview and foreign policy bolstered Saudi's position both internally and externally, they exposed the kingdom to criticism with the slightest deviation from what was deemed as the Islamic ideal. During the annual pilgrimage season on November 20, 1979, the siege of the mosque in Mecca by Juhayman al-Utaybi and Muhammad al-Qahtani was the strongest manifestation of that underlying tension in Saudi Arabia. Prior the siege, Juhayman had preached strongly against relations with "infidel powers," materialism and corruption. He was a strong voice in delineating the appropriate relations between ulama and power. The accusatory rhetoric that Juhayman espoused against the Saudi ruling family had strong resemblance to that of Ikhwan against Abdul Aziz in the late 1920s. "Religious and moral laxity and degeneration of the Saudi rulers" were among the charges made against the ruling family ${ }^{610}$ In response, King Khalid had Shaikh Abd al-Aziz Ibn Baz issue a fatwa in support of the ruling family

\footnotetext{
${ }^{609}$ The sons of a Sudairi mother. Sudairi Seven was consisted of Crown Prince, Fahd; second deputy prime minister and the minister of defense and aviation, Sultan; minister of interior, Nayef; governor of Riyadh, Salman; vice minister of defense and aviation, Abd al-Rahman; vice minister of interior, Ahmad; and vice minister of defense, Turki.

${ }^{610}$ James Buchan, "Secular and Religious Opposition in Saudi Arabia," in Tim Niblock ed. State, Society and Economy in Saudi Arabia (Routledge, 2015) 120-124.
} 
and the use of military force in and around the holy sites. In a matter of two weeks, Saudi forces crushed the neo-Ikhwanian rebellion, killed al-Qahtani, arrested Juhayman and some 170 of his followers.

King Khalid had to face the outcome of other social tensions that were created during the reign of King Faisal including the unrest in the Eastern Province where the majority of Saudi Shiite lived. Discrimination against Shiites on theological, economic and social levels ${ }^{611}$ gave rise to grievances strong enough to foment unrest in the Eastern Province where the oil industry was based. These grievances exacerbated by the success of the Iranian revolution in 1979 and the anti-Saudi rhetoric of the post-revolutionary Iranian leadership, turning some Shiite activists into "Muslim rebels."

King Khalid's period of reign was contemporaneous to major regional events with serious repercussions for the Saudi domestic scene. Notable events in this regard were the 1979 Islamic Revolution in Iran which inspired Islamic activism in several Arab countries including Saudi Arabia, scathing criticism of the Saudi-American relations by the postrevolutionary Iranian leadership, Soviets invasion of Afghanistan which made Saudi ruler more apprehensive than before of communist threat, and the Iran-Iraq war which brought a large-scale regional conflict to Saudi borders.

\footnotetext{
${ }^{611}$ Madawi Al-Rasheed, "The Shi'a of Saudi Arabia: a minority in search of cultural authenticity." British Journal of Middle Eastern Studies 25, no. 1 (1998): 131.

${ }^{612}$ Al-Rasheed,. A history of Saudi Arabia. 141.
} 


\section{Iranian-Saudi anti-Communist Collaboration within the Framework of Safari Club}

In the years to follow, Iran and Saudi Arabia under King Khalid collaboratively assisted the United States conclude a peace treaty between Israel and Egypt. The support Egypt received from Iran and Saudi Arabia helped Anwar Sadat break with radical Arab states which culminated in the conclusion of the Sinai Agreements in 1974, 1975 and eventually the 1979 Camp David Accords. By the end of the negotiation process, Saudi Arabia and Iran had withdrawn from the forefront of efforts to lead Egypt into the Western hemisphere, allowing the US to take credit for their past efforts.

In 1976, Iran and Saudi Arabia joined Morocco, Egypt, Israel and France to form the so-called Safari Club. The club was an elite intelligence force, meant to thwart leftist governments and support anti-communist regimes. The formation of the club was contemporaneous with the United States reluctance to get dragged into conflict zones; however, the group maintained an informal connection with the CIA. The United States government deemed the formation and maintenance of the Club vital to the American interests, specifically in the aftermath of interesting events in U.S. domestic politics which had disrupted the government's modus operandi. The US Congress had passed the War Powers Resolution in 1973 and the Clerk Amendment in 1976 in reaction to the Executive branch's involvement in decades of covert military actions. ${ }^{613}$ These Congressional moves came at the heels of the revelations by the Rockefeller Commission and the Church Committee regarding the government's utilization of CIA and FBI in illegal operations. Therefore, Kissinger avidly advocated supporting the Club without partaking in it so that

\footnotetext{
${ }^{613}$ Mahmood Mamdani, Good Muslim, bad Muslim: America, the Cold War, and the roots of terror. (Harmony, 2005) 80-84.
} 
it would effectively fulfill American objectives by proxy. He firmly believed that America should "get others to do what [it] want[s] done, while avoiding the ... blame if the operation fails. ${ }^{\circ 614}$ Prince Turki Al-Faisal who served as the head of the Saudi intelligence service in those crucial years captured the essence of the time in his 2002 speech at the Georgetown University. Turki al-Faisal said, "Your intelligence community was literally tied up by Congress. It could not do anything.... In order to compensate for that, a group of countries got together ... and established what was called the Safari Club. The principal aim of this club was that we would share information with each other and help each other in countering Soviet influence worldwide, and especially in Africa. ${ }^{615}$

The club's notable accomplishments, among others, are successful military intervention in Zaire in response to an invasion from Angola, providing arms to Somalia in its conflict with Ethiopia during 1977-1978, and contributing to the initiation of peace negotiation between Egypt and Israel. The club was heavily funded by Saudi Arabia and Iran, and the heads of the intelligence apparatus in both states kept close contact to coordinate the effort. Iranian-Saudi collaboration within the Safari Club framework continued until 1979 Iranian revolution. ${ }^{616}$

\footnotetext{
${ }^{614}$ John K. Cooley, Unholy wars: Afghanistan, America and international terrorism. (Pluto Press, 2002) 24.

${ }^{615}$ Quoted in Joseph Trento, Prelude to Terror: Edwin P. Wilson and the Legacy of America's Private Intelligence Network. (Basic Books, 2009) 102.

${ }^{616}$ Keynoush, Saudi Arabia and Iran, 90.
} 


\section{Saudi's Perception of the Tumultuous Year Leading to the Islamic Revolution in Iran}

Shah insisted on the Iranian role in the preservation of the Persian Gulf security as late as March 1978 in spite of the events unfolding in Iran. In an interview with London BBC, when asked by Richard Kershaw if Iran was prepared to intervene in the Persian Gulf region to counter further radicalization of the Arab world and eventual emergence of leftwing regimes, Shah responded, "Certainly, this is our duty." ${ }^{.617}$ In spite of that posture, it was Iran that was undergoing the most radical of a shift in the region. The recurrent unsettling unrest, strikes and demonstrations around the country had the entire region vigilantly watch the course of events in Iran.

Concerned with the anti-regime cries and rallies in Iran, King Khalid sent Prince Sultan ibn Abdul Aziz, the Saudi Minister of Defense and Aviation, to pay a 3-day official visit to Iran. In an audience with Mohammad Reza Shah on April 11, 1978 Prince Sultan conveyed to the Shah the greetings of his brother King Khalid and the Crown Prince Fahd. During this audience, which was attended by Iranian War Minister, General Reza Azimi and Saudi Ambassador in Tehran Shaikh Ibrahim Bakr, the two sides reviewed bilateral relations and explored ways to strengthen mutual cooperation in various fields. ${ }^{618}$

On the very same day, the newspaper al-Madinah published an article titled "We and Iran Are One Nation," which termed the relations between the two states "fraternal" and bonded by "spiritual ties." The article praised the cooperation between Riyadh and Tehran, underscored the significant role that the two countries played in the region and the world at large, and emphasized the determination of the two countries to continue their close

\footnotetext{
617 “Shah Interview on Mideast, African, Internal Issues," FBIS-MEA-78-048).

${ }^{618}$ FBIS-MEA-78-071, April 12, 1978.
} 
coordination and consultation in variety of security-related issues. ${ }^{619}$ The official visit to Iran by Prince Sultan and al-Madinah's quick coverage of it are signs that Saudis were anxiously tracing the turn of events in Iran, and in hindsight, the unraveling of a kingdom.

Eight days later, on April 19, Sheikh Hisham Nazir, the Saudi Planning Minister, left Riyadh for Tehran. According to Riyadh SNA, Nazir was carrying an important message form King Khalid for the Shah of Iran. The nature of the message has not been documented to this day. This visit, which occurred only few days after Prince Sultan's visit to Iran, did not last more than a day but one can speculate that it was encouraged by the Saudis' consternation over upheavals in Iran. ${ }^{620}$

Meanwhile, in Najaf, the leader of the movement, Ayatollah Khomeini had no hesitation in rendering his harsh critique of the Shah and the incumbent regime in Iran. This critique, one can argue, further exacerbated Saudis' anxiety over the Iranian uprising since there were alarming resemblances between the Iranian and Saudi polities. In an interview with Le Monde on May 6, 1978, Ayatollah Khomeini asserted:

In all my proclamations to the Iranian people over the past 15 years, I have always called strongly for the economic and social development in my country. But the Shah, implementing the imperialists' policy, strives to keep Iran in a backward state. His regime is dictatorial [and has no respect for] individual freedoms ..., real elections, the press and parties. In violation of the constitution, deputies are imposed on people by the Shah. Political and religious associations are prohibited, and independence of the courts and cultural freedom no longer exists. The Shah has assumed all there powers. He has established a single party system and ...has made it compulsory to join it. ${ }^{621}$

\footnotetext{
${ }^{619}$ FBIS-MEA-78-072, April 13, 1978.

${ }^{620}$ Riyadh SNA, April 19, 1978. See FBIS-MEA-78-077. April 20, 1978.

${ }^{621}$ Le Monde, May 6, 1978. See FBIS-MEA-78-091. May 10, 1978.
} 
Putting aside negligible specificities, this critique of the regime in Iran was as applicable to Saudi Arabia as it was to Iran. Watching how a strong a regime backed by the United States was shaken by recurrent riots, strikes and rallies was unsettling to a regime that had its own host of domestic threats and vulnerabilities.

Another special meeting between the Iranian-Saudi officials took place on May 10, 1978. In this meeting Crown Prince Fahd ibn Abdul Aziz received Manuchehr Zelli, the undersecretary of the Iranian Foreign Ministry, who handed him a message from the Shah of Iran. The meeting was attended by the Saudi undersecretary for political affairs in the foreign ministry and the Iranian ambassador to Saudi Arabia. After the meeting, Saudis maintained that the message was about common matters of interest, falling within the framework of the Iranian-Saudi consultations in the interest of the two countries and peoples. ${ }^{622}$ The text of the message is still unknown.

On August 24, 1978, Saudi officials publicly, for the first time, expressed their concern about the turbulence on the Iranian streets. In an interview, Prince Sultan ibn Abdul Aziz, the Minister of Defense and Aviation, stressed the importance of stability in Iran. Concerned with the rise in the gravity of the matter, Prince Sultan warned "that any fundamental disturbance in the situation will upset the security balance in the whole region." ${ }^{263}$ In another interview with on the same day, Prince Sultan accused communism and international left of fomenting the riots in Iran. He reiterated his concern that "any basic disruption [in Iran] is bound to affect the security situation in the entire area." ${ }^{624}$

\footnotetext{
${ }^{622}$ Riyadh SNA, May 10, 1978. See FBIS-MEA-78-092. May 11, 1978.

${ }^{623}$ Kuwait Domestic Service, August 24, 1978. See FBIS-MEA-78-166. August 25, 1978.

${ }^{624}$ Manamah Gulf New Agency, August 24, 1978. FBIS-MEA-78-166. August 25, 1978.
} 
On Nov. 20, 1978, Saudi Foreign Minister, Prince Saud al-Faisal states that Iran was of great importance to the region and the world and "any problem in Iran [would naturally] provoke anxiety." Prince Saud hoped that the situation in Iran would calm down so that it would resume its important role in the region. He emphasized that Saudi Arabia encouraged the Shah to remain in Iran and continue with his reign. He maintained that the achievements of Mohammad Reza were an example for any state aspiring development. ${ }^{625}$ In an interview with a London-based Arabic newspaper on December 22, 1978, Ayatollah Khomeini addressed the nature of Sunni-Shiite divide and the prospect of relations between an Islamic republic in Iran and the royalist regimes in the Persian Gulf region. Ayatollah Khomeini in response to a question regarding the nexus of incidents in Iran and Sunni-Shiite differences said, "I have addressed an appeal to our Sunni brothers thanking them for their struggle against the shah. The Sunnis are out brothers and will remain so." He also replied to a question regarding the nature of relations with the Arab countries littoral to the Persian Gulf after the establishment of the Islamic republic asserting, "the Islamic republic in Iran will continue to deal with all countries that respect the independence and freedom of the Iranian people on the basis of the mutual respect provided that contact and dealing with these states does not jeopardize and violate the Islamic laws and values, to which the Iranian Islamic republic will strongly adhere." ${ }^{26}$ In an interview with Radio Luxemburg on January 11, 1979, Ayatollah Khomeini echoed the

\footnotetext{
${ }^{625}$ FBIS-MEA-78-224. Nov. 20, 1978.

${ }^{626}$ FBIS-MEA-78-248. Dec. 26, 1978.
} 
same principle, stating that the Islamic republic would maintain friendly relations with all those nations who desire such ties. ${ }^{627}$

On January 6, 1979, Crown Prince Fahd made interesting commentary on the Iranian upheavals, demonstrating an uneasy vacillation whether to fully support the incumbent regime in Iran or prepare for an overhaul. In a statement to Saudi paper alJazirah, Crown Prince Fahd expressed the Saudi Kingdom's support for the regime of Shah in Iran on the ground that it was based on legal legitimacy. He said that Saudi Arabia supports any legal regime in Iran, but also affirmed that the regime of Shah was legal and had the support of its Saudi counterpart. He continued that the situation in Iran was detrimental to the stability of the region. ${ }^{628}$

On January 16, 1979, the days that Shah fled Iran, Saudi paper Okaz expressed concerns over the growth of communist activities under the leadership of Tudeh Party with an aim to win supporters amidst popular unrest in Iran. The author of the piece discounts the complexity of the pre-revolutionary alliance among disparate forces. The disparaging language of this editorial in accounting for how that alliance came to be is notable. Okaz wrote:

The communist party which has returned from exile, imagines that, through absolute or partial power, it can bring about ideological and philosophical changes in the country's domestic and foreign policies through new commitments reflecting strategic ties influencing current Middle East events. The other extremist side is not aware of this fact. Therefore, this side, which includes Shiite religious leaders, has deliberately declared that the political color of the future state, after the Shah's temporary or permanent departure, will be purely Islamic and not subject to influence by any other internal and external forces so as to curb the role of the communist party, with which it was allied during the struggle and with which it is now in conflict during the struggle for power. However, the communist party is

\footnotetext{
${ }^{627}$ FBIS-MEA-79-009. Jan. 12. 1979.

${ }^{628}$ FBIS-MEA-79-005. January 8, 1979.
} 
now countering this religious trend, which the popular masses support because of their deep Islamic beliefs through misleading actions and by exploiting the ignorance of the majority of the masses. This ignorance is the result of incorrect educational and cultural policies, lacking in foresight, which were pursued prior to these incidents. Such policies have enabled the communists to raise false slogans that they have tried to ascribe to religious beliefs, such as justice and equality, thus succeeding in winning support among the broad base, which believes in Islam. ${ }^{629}$

After Ayatollah Khomeini returned to Iran after years in exile, Riyadh in a commentary expressed concern about the future course of events in Iran; however, the tone and language used in this commentary reflected a departure Okaz's coverage of Iran, and Saudis' gradual move to embrace the political overhaul in Iran. This commentary reads:

[Iran,] this great Islamic county has witnessed, particularly in the past few days, developments whose impact on the various aspects of life there cannot be underestimated. The question which poses itself most persistently now is [if] the return of ...Ayatollah Khomeini to his country means that calm and tranquility will return to Iran or the trouble will be intensified. The answer to this question is ...extremely difficult, for only the Iranian people themselves can create calm and restore tranquility to Iran. Iranian people are capable of overcoming these troubles and difficulties and of saving their country from the tribulations of division and anarchy. The Arab and Islamic nation prays with hope to God to protect Iran and save it from all ill, for any challenge to any Islamic country is a challenge to the entire Islamic nation. ${ }^{630}$

On February 4, Riyadh, clearly in reaction to recent developments in the region, commented on the composition of Saudi foreign policy in a vague language open to interpretation. This declaration was indicative of an anxiety that Saudi officials felt as of massive change one of the most stable countries in the region was going through. Riyadh declared in this commentary:

\footnotetext{
${ }^{629}$ FBIS-MEA-79-016. January 23, 1979.

${ }^{630}$ FBIS-MEA-79-024. Feb. 2, 1979.
} 
Once again, we recall and important question imposed by events: What governs Saudi foreign policy and decide its directions? We repeat the questions while comprehending with great satisfaction that our language is understandable at the Arab, Islamic and international levels. We do not speak with a faint voice; we do not deal with events with ambiguity. Many new developments in the Middle East have confirmed that all that the kingdom has warned against has happened and that what it is warning against requires a quick review of all our calculations in order to prevent it from happening. ${ }^{631}$

Saudi Foreign Minister, Prince Saud al-Faisal in an interview granted to the Kuwaiti paper, KUNA on February 5, clarified on the ambiguous Saudi position in the February 4 commentary. Prince Saud al-Faisal asserted that as long as the events in Iran remained of an internal nature, Saudi Arabia would have no position, but it opposed any changes that were likely to attract foreign interference. ${ }^{632}$ On the same day, the Saudi Council of Ministers met with the Crown Prince Fahd ibn-Abdul Aziz. In this meeting, Prince Fahd pointed out that the Saudi policy of supporting the Arab right and noninterference in the internal affairs of other states has not changed due to the latest development in the region. ${ }^{633}$ In another events on February 5, Prince Saud al-Faisal had an extensive interview with the special correspondent of al-Siyasah on the developments in Iran. Saud al-Faisal expressed that Saudi Arabia had nothing against the developments in Iran as they were reflective of the demands of the Iranian populace, but he asserted that Saudi Arabia opposed any change that disrupted the balance of power in the region. However, the impact of developments in Iran was by no means contained within its bounds. In fact, what the

\footnotetext{
${ }^{631}$ FBIS-MEA- 79-026. Feb. 6, 1979.

${ }^{632}$ FBIS-MEA-79-025. Feb. 5, 1979.

${ }^{633}$ FBIS-MEA-79-026. Feb 6, 1979.
} 
Saudi officials feared as of the direct or inspirational influence of the Iranian Islamic revolution was a legitimate threat to the Saudi rule and not far from reality.

The paradigmatic shift in the foreign policy of post-revolutionary Iran was a rejection to the regional status-quo and a challenge to the legitimacy of the monarchic regimes in power. According to Ayatollah Khomeini, monarchic and secular forms of governance were incompatible with Islamic injunctions. He had declared in the 1970s that monarchy is "one of the most shameful and disgraceful reactionary manifestations. ${ }^{9634}$ Drawing upon Shiite imageries and symbols ${ }^{635}$ Ayatollah Khomeini had called upon religious leaders of all traditions to fight monarchic systems. Saudi Arabia was host to various opposition fronts with which Ayatollah Khomeini's call could resonate. On February 14, Al-Safir, published in Beirut, inquired into the recent unrest behind the "border curtain of the Kingdom of oil and silence" suggesting that something menacing was brewing and it was logical to think that events in Iran had played a role in kindling that. ${ }^{636}$

Saudi Arabia was about to experience another round of Islamist resurgence in the likes of 1920s Ikhwan revolt, but this time motivated and inspired by the success of the Islamic Revolution in Iran. This challenge unlike what Abdul Aziz had handled successfully emerged in an environment filled with anxiety and doubt. The collapse of a monarchy in the region in face of revolutionary passions led by a religious leader brought to the fore Saudi's fear of its own religious fundamentalists. In addition, the fall of a

\footnotetext{
${ }^{634}$ Rouhollah Khomeini, Islam and Revolution. Writings and Declarations of Imam Khomeini, tran.by Hamid Algar, (Berkeley, CA: Mizan, 1981) 204.

${ }^{635}$ ibid. 204-205.

${ }^{636}$ FBIS-MEA-79-032. Feb 14, 1979.
} 
monarchy amidst the United States hesitancy to prop up the regime of a much closer ally left the House of Saud with questions as to what the United States would do to support the Saudi Kingdom in face of threats posed by religious fundamentalists. ${ }^{637}$

The inspiring success of the Iranian Revolution coupled with "American impotence in face of Islamic vengeance" 638 further corroborated by the Iranian students storming into the American embassy in Tehran and taking hostage American diplomats emboldened Juhaiman al-Utaibi and Abdollah al-Qahtani to seize the Grand Mosque of Mecca with the support of two hundred to three hundred men. Clearly inspired by the charges hurled Iran's Ayatollah Khomeini, Juhaiman denounced the legitimacy of the rule by the House of Saud on the charge that monarchies are alien to Islam in front of thousands of worshipers that were beseeched in site. Saudi officials emerged from this crisis triumphant and eventually purged the vault of the Grand Mosque from "corrupt gang of renegades," in the words of Amir Nayif ibn Abdul Aziz, the Saudi Interior Minister. ${ }^{639}$ However, the House of Saud could not ignore the fact that even though Juhaiman and his followers were some Wahhabi zealots but their movement was inspired by the paradigm of the Islamic Revolution which was admired among religious students in Mecca in 1979.

There is no evidence confirming that Saudi Shiites played any role in Mecca uprising despite speculations to that effect. The Saudi Shiites, however, were not immune to the message of the Islamic Revolution from across the Arabian Peninsula. This message resonated well with their long-standing grievances against the House of Saud. The Islamic

\footnotetext{
${ }^{637}$ Sandra Mackey, the Saudis, Inside the Desert Kingdom, (Boston, Houghton Mifflin Company) 228-229.

${ }^{638}$ Ibid. 229.

${ }^{639}$ FBIS-MEA-79-234. Dec. 4, 1979.
} 
Republic of Iran had assumed "an eternal mission for emancipation of the "oppressed" around the world. ${ }^{940}$ This self-bestowed universal mission was predicated on the unique interpretation of Ayatollah Khomeini of the Shiite political theory ${ }^{641}$ Central to Ayatollah Khomeini's political worldview was the Manichean imagery of constant struggle of the "oppressed" against the "oppressors". ${ }^{642}$ Joining the leftist Zeitgeist of the time from a theological angle, Ayatollah Khomeini had assigned the Islamic Republic of Iran, a moral duty to act as the agent of bringing about the triumph of the oppressed against the oppressors. ${ }^{643}$ In December, while observing Ashura, the Shiite day of mourning that commemorates the death of Imam Hussein, the residents of Qatif took to the streets with such fervor that the National Guardsmen had to engage them with panic resulting in violence and bloodshed. In February riots broke out once again with Shiite demonstrators in Qatif pouring out their wrath against the tyranny of Najdi Wahhabi majority. The National Guard, once again, met demonstrators with brute force. ${ }^{644}$

Ayatollah Khomeini's emphasis on poor masses and his call for social justice and political participation remained threatening to Saudi Arabia, Kuwait and Bahrain in which Shiites were more socio-economically disadvantaged than their co-religionists in Qatar, the UAE or Oman. However, in response to the disturbances stirred by provocative Iranian post-revolutionary foreign policy, Saudi Arabia managed to calm mass discontent

\footnotetext{
${ }^{640}$ Adib-Moghaddam, The international politics of the Persian Gulf, 23.

${ }^{641}$ Roy Mottahedeh, "Shi' ite Political Thought and the Destiny of the Iranian Revolution," in Jamal S. alSuwaidi (ed.), Iran and the Gulf: A Search for Stability, (Abu Dhabi: The Emirates Center for Strategic Studies and Research, 1996) 70-80.

${ }^{642}$ Farhang Rajaee, Islamic Values and Worldview: Khomeyni on Man, the State and International Politics, vol.XIII, (Lanham, MD: University Press of America, 1983)

${ }^{643}$ Ervand Abrahamian, Khomeinism. Essays on the Islamic Republic, (London: I.B. Tauris, 1993)

${ }^{644}$ Ibid. 236-237.
} 
by improving the living conditions in Hasa province while keeping a watchful eye on the Shia community. In November 1980, King Khalid visited Hasa, spoke to Shia leaders and heard their grievances. This further improved the atmosphere in the Eastern Province. These developments stopped any further uprisings, in particular as the Saudi Shia had no institutional links with the clerics in Iran.

The anti-monarchic narrative central to Ayatollah Khomeini's political theory was antithetical to the ruling elites in the Arab monarchies of the region. Ayatollah Khomeini castigated the Al-Saud's "frivolous and shameless way of life," which, according to him, reflected no adherence to Islamic morality. ${ }^{645}$ The clash between Iran and Saudi Arabia, however, was not limited to Ayatollah Khomeini's reproach of the Al-Saud's hedonism. Saudi Arabia represented a conservative, status-quo-oriented, pro-Western hereditary monarchic system which made the symbiosis with the revolutionary, idealistic, antiimperialist and anti-monarchical Iran extremely difficult. ${ }^{646}$

\section{Concluding Remarks}

Despite the relatively stable period between 1969 and 1978 in which Iran and Saudi Arabia could align their policies and tacitly cooperate on many levels, that cooperation did not spawn a radical change in the historical patterns of amity/enmity between the two states as Saudi Arabia and Iran never surmounted their mutually stigmatizing differences deeply embedded in their political cultures. In other words, while the facade of interactions between the two states in this decade alludes to cooperation, the convergence of policies

\footnotetext{
${ }^{645}$ Goldberg, "The Shia Minority," 243.

${ }^{646}$ Ramazani, Revolutionary Iran, 44-45.
} 
between the two countries did not occur as the result of a genuine transformation in historical perceptions. The reason is to be sought in an exacerbated Arab-Persian divide which was pushed to the back of geopolitical considerations, yet limiting the extent of an Iranian-Saudi integration.

The insistence of Shah on an exclusionary and chauvinistic 'Iranianist' state identity, in the likes of his father's, was perceived as "belligerent" by the Arab states in the region. Iranian nationalism in this period appeared as an expansionist and hegemonic ideology threatening its geographical, ethnic and cultural neighbors. ${ }^{647}$ Mohammad Reza Shah, following the path of his father, nurtured the notion of Iranianism by linking his rule to ancient, pre-Islamic Persian empires. ${ }^{648}$ The Iranian self that Shah was promoting in this period was embedded in the romanticized idea of Aryan superiority over Arab-Semitic other. ${ }^{649}$ Such self-identification was anathema to genuinely communitarian relations among the Arab states in the Persian Gulf region. ${ }^{650}$

In this ideational context where racially coded Iranian supremacy over the ArabSemitic people was emphasized as the basis for essentializing the Iranian self, Arabs had begun to develop their own vitriolic discourse towards Iranians. Drawing upon the

\footnotetext{
${ }^{647}$ Wajih Kawtharani and Khair el-Din Haseeb. "Mutual awareness between Arabs and Iranians." ArabIranian Relations (Beirut: Centre for Arab Unity Studies, 1998) 75.

${ }^{648}$ For an interesting account of the variant of Iranian nationalism, see Firoozeh Kashani-Sabet, "Cultures of Iranianness: The Evolving Polemic of Iranian Nationalism", in Nikki R. Keddie and Rudi Matthee (eds), Iran and the Surrounding World. Interactions in Culture and Cultural Politics, (Seattle, WA: University of Washington Press, 2002) 162-181.

${ }^{649}$ For a comparison of the representation of 'self' and 'other' in Iranian textbooks before and after the revolution see Golnar Mehran, 'The Presentation of the "Self" and the "Other" in Postrevolutionary Iranian School Textbooks,' in Keddie and Mathee (eds), Iran and the Surrounding World. 232-253; See also Shahrokh Meskoob, Iranian Nationality and the Persian Language, trans. (Washington, DC: Mage, 1992).

${ }^{650}$ See Mohammad Reza Pahlavi, Answer to history. (Stein \& Day Pub, 1980)
} 
metanarrative of "Arab nationalism"651 developed by Sati Khaldun Al-Husri, ${ }^{652}$ Arabs invoked a political strategy that excluded Iran from the arena of inter-Arab politics by advocating the myth of perennial antagonism between Arabs and Persians. Accordingly, the Arabs, in their definition of self and advocacy of Arab volkgeist externalized Iranians as others. According to this view, the Arab nation was a cultural entity held together by a common language and shared common folklore, a nation that is to be protected from its chief nemesis, the Persians. In his survey of the image of Iranians in Arab school textbooks, Talal Atrissi demonstrates that Iranians are mostly introduced as "racist" Persians who constantly "conspire against the Arab nation, its unity and its language, as well as the Islamic Arab civilization." Atrissi confirms that Persians are largely portrayed as evil invaders constantly conspiring against the Arab nation, and causing sectarian conflict and unrest in the Arab world. Nevertheless, there are variations of this portrayal in various Arab societies, and as Atrissi documents, this portrayal, for example, is much softer in Saudi textbooks than their Iraqi counterparts. ${ }^{653}$ This ideational divide effectively stymied the prospect of transforming the communitarian norms and aligned policies into a functioning security community architecture. In other words, Iranian-Saudi relations from 1962 through 1979, by and large, moved in a canal as a synthesis of common threats with cooperative norms catalyzed by the Nixon Doctrine provided a ground where the two states

\footnotetext{
${ }^{651}$ Bassam Tibi, Arab nationalism: between Islam and the nation-state. (Springer, 1997).

${ }^{652}$ Prominent $20^{\text {th }}$ century Syrian writer and Arab nationalist thinker who advocated a culturalist interpretation of political community. He suggested that because of the common linguistic bond and their eternal kinship, Arabs were destined to fulfill a sacred mission as a resurgent nation. See Sati Al-Husri quoted in Paul Salem, Bitter Legacy, Ideology and Politics in the Arab World (Syracuse, NY, 1994) 57.

${ }^{653}$ Talal Atrissi, "The Iranian Image in Arab School Books," in Discourse: An Iranian Quarterly, vol. 1, no. 1 (Summer 1999) 103-56.
} 
could manage to overcome some of their historical grievances against one another, yet that effort was capped by ideational differences fundamentally dividing the two states along cultural fault-lines.

With the 1979 Islamic revolution and the Soviet invasion of Afghanistan, the regional stability of the 1970 s — determined by the Saudi-Iranian equilibrium — collapsed which led to a long period of bloodshed and hostility in the region. The 1970s cooperative norms which were consonant with the global norms of 'appropriate behavior' had ameliorated the contentious effect of diverging interests and exclusionary narratives of state identity. The Islamic Revolution was essentially anathema to that order. The role that Iranian revolutionaries had defined for the Islamic Republic of Iran was a blunt rejection of the role assigned to the state under Nixon's Twin-Pillar doctrine. ${ }^{654}$ The crux of the new role was the notion of "neither East, nor West," which called for a radical nonalignment policy and detachment from the Cold War rationale. ${ }^{655}$ Despite the forbidding exigencies of the Cold War, this ambitious approach turned Iran from the guardian of the status-quo under the patronage of the United States to a revisionist state. ${ }^{656}$

The paradigmatic shift that the Islamic revolution introduced to the region overhauled the essence and character of regional interaction in the Middle East. The postrevolutionary Iran was intent to unilaterally determine the outcome of regional politics within the forbidding context of the Cold War. The natural corollary to such self-

\footnotetext{
${ }^{654}$ Arshin Adib-Moghaddam, The international politics of the Persian Gulf: a cultural genealogy (Routledge, 2006).

${ }^{655}$ Mehrzad Boroujerdi, "Iranian Islam and the Faustian bargain of Western modernity." Journal of Peace Research 34, no. 1 (1997): 1-5.

${ }^{656}$ Rouhollah Ramazani, Revolutionary Iran: challenge and response in the Middle East. vol. 237. (Baltimore: Johns Hopkins University Press, 1986); John L. Esposito, ed. The Iranian revolution: Its global impact. (Florida International University Press, 1990)
} 
attributed revolutionary state identity was an effort to export the revolution by the "true and unique Islamic state. ${ }^{957}$ Accordingly, Iranian revolutionary/ideological turn exposed the receptive sub-state political constituencies in other polities in the region, specifically Shiites. The revolutionary message that the marginalized Shiite communities in the region received from Iran served as an impetus for their struggle against their suppressive states. ${ }^{658}$ This means that Iran's interaction with the Persian Gulf states and the wider Muslim world, in negation of the orthodox nation-state principles of the Westphalian system, became one of interaction with the states in the composite sense of the word as opposed to its unitary sense.

Soon, the media outlets of the time, religious sermons and seminars, pamphlets of propaganda material, as well as Iranian embassies became the means to propagate the Iranian revolutionary message. In Arabic language, programs broadcasted from major hubs, ${ }^{659}$ the Iranian government attacked the United States, criticized the collusion between the Arab states and the US, and denouncing the region's Arab governments' harsh treatment of opposition groups. Through frameworks such as the Association of Militant Clerics and the Revolutionary Guards, the Congress of Friday Imams and Prayer Leaders, and the Revolutionary Islamic International, Islamic Republic of Iran coordinated a network of activist clerics, Shiite and Sunni alike, to help import the

\footnotetext{
${ }^{657}$ See the preamble of the Constitution of the Islamic Republic of Iran.

${ }^{658}$ Oliver Roy, the Failure of Political Islam, trans. by Carol Volk, (London: I.B. Tauris, 1999)187.

${ }^{659}$ See e.g. FBIS/SAS/I9 25 June 1980; FBIS/SAS/I13, 3 September 1980; FBIS/SAS/I13, 24 October 1980.
} 
Iranian Revolution into their respective countries. ${ }^{660}$ Also, the Foreign Ministry and Iran's representatives abroad were assigned to "voice Iran's views to the world" and "convey the message of the Islamic revolution." ${ }^{661}$ Ali Shams Ardakani, Iran's Ambassador to Kuwait, confirmed in 1982 that "The Islamic revolution will reproduce itself in places [plagued by] oppression and social injustice... [therefore] it would be stupid to believe that revolutionary ideas stop at state boundaries. ${ }^{662}$

\footnotetext{
${ }^{660}$ See Robin Wright, Sacred Rage: The Crusade of Modern Islam (New York: Linden Press, 1985), 27; Marvin Zonis and Daniel Brumberg, Khomeini, the Islamic Republic of Iran, and the Arab World, No. 5. (Center for Middle Eastern Studies, Harvard University, 1987) 32.

${ }^{661}$ FBIS/SAS/I2, 4 November 1985; FBIS/SAS/I14, 5 January 1980.

${ }^{662}$ Le Monde, 12 May 1982.
} 


\section{CHAPTER VII}

\section{$\underline{\text { CONCLUSION }}$}

In this research, an attempt was made to identify dynamics of Iranian-Saudi relations, trace patterns of amity/enmity in these relations, and examine the operation of some variables commonly referred to as chief/contributing factors in these relations. Below, a brief account of the elements that proved to be enduring factors in shaping/influencing Iranian-Saudi relations are provided. Here, the emphasis will be on major themes that capture the essence of Iranian-Saudi relations in decades of their coexistence. Accordingly, minor incidents and encounters have been excluded.

Iran and Saudi Arabia as an entity in the formation had their first encounter in the 1920s, when Reza Khan began securing Iran's interior, responding to several revolts that erupted against his new government and suppressing the federal rulers of Qajarid Iran. In November 1924, Reza Khan launched a campaign to subdue Sheikh Khazal's rebellion in Khuzestan. Abdul Aziz perceived Reza Khan's campaign to subdue Sheikh Khazal in November, 1924 threatening. This encounter had the Saudis suspect Reza Khan's expansionist drive, closely monitor Persia's next move, and follow further regional developments with insecurity. In other words, geopolitical considerations informed Iranian-Saudi relations from the outset. The measures that Abdul Aziz employed in response to Reza Shah's growing power and rising star with the British attest to the role and significance of geopolitics in Iranian-Saudi relations. To be more precise, Abdul Aziz — concerned with Persia's expansionist drive into the Arabian Peninsula — concluded the 1927 Treaty of Jeddah with Britain in order to preempt the materialization of such a scenario. In another move, Abdul Aziz — having witnessed Britain's failure to protect its 
Arab ally — unilaterally appeased Iran in 1929 Treaty of Friendship. These events provide an empirical case for mutual construction of security perceptions, practices and policies between the two states. In other words, the sequence of events according to the available data reflect an incontrovertible case of security interconnectedness. Also, the Iranian-Saudi relations in this period reflect a notable level of agency that both Iran and Saudi Arabia exercised despite British hegemonic power in the region

In the 1930s, an ethno-racial rift as an enduring component was introduced to the Iranian-Saudi relations. This period of Iranian-Saudi relations was puzzling as Persia pursued a policy of avoiding any engagement with infantile Saudi Arabia. In order to give presence to Saudi entity in the region and reaffirm their assumed identity, Saudis desired to engage Iran but much to their disappointment, Persia did not reciprocate that desire, making a curious case of "disregard" in foreign policy. The notion that Saudis sought affirmation for their identities [a matter of ontological security] in an engagement with Persia provides yet another case of security interconnectedness. Two factors of geopolitics and geo-culture explain the course of (non)events in this decade. Geopolitically, Persia's primary concern rested with the threats posed by Russia and Britain. To be more precise, there was neither any real or perceived threat posed by the neighboring Arab states that would amount to that level of gravity, nor these states could be part of any solution to Persia's affliction with Russo-British interventionist policies. However, an ideational/geo-cultural element contributed to such an outcome in conjunction with the abovementioned geopolitical considerations. This element had to do with the gradually dominating narrative of Iranian nationalism predicated on a romanticized notion of glorious pre-Islamic Persia which was essentially anti-Arab. This 
racist/racialist notion informed Reza Shah's European-style modernization and the pursuit of the Persian fate in relation with Europeans and not "racially sub-par Arabs." The (re)construction of Iran's classical past as an epoch in which the nation existed in its homogeneous and untarnished form was the foundation of the nationalist discourse that emerged out of a complex interplay between mobilized myths and legends representing pre-Islamic Iranian culture and an appropriation of racialist Aryanism. This essentially anti-Arab discourse defined Reza Shah's foreign policy toward Arab states, specifically Saudi Arabia. The relevance of Persian-Arab divide for the states' preferences, policies and practices which endured as a subtext to the Iranian-Saudi relations for the subsequent decades had its origin in this period.

In the 1940s, the role and relevance of great power politics as yet another enduring factor in shaping the Iranian-Saudi relations became apparent. The exigencies of the new era made it both functionally and normatively mandatory for the states to subscribe to the ethos of either the Western or Eastern bloc. Without any vacillation, both Iran and Saudi Arabia submitted to the patronage of the United States. Therefore, clientelism in a variety of degrees and sense became a common feature in both Iranian and Saudi foreign policies in this period. Nevertheless, the two states exhibited two distinct modes of clientelism despite the sameness of their patron. For Saudis, clientelism was a desirable mode, a status to aspire for, and a condition that was a host of political and economic benefits. Saudi Kings, except for a short period of policy disarray during King Saud's reign, enthusiastically desired continued American involvement in the region which could mean more American aid and contribution to the development and stability of Saudi Arabia. Furthermore, such a presence and active involvement of the 
United States in the region, Saudi Kings were convinced, was a protective measure for the House of Saud in face of a large swath of domestic threats to their rule. The material and ideational compromises that Saudi Arabia have historically made to carve themselves a secure space in American strategic thinking, thus ensuring the continued support of the United States demonstrates the gravity of this matter for Riyadh. On the other hand, a clientelist status has never been Iran's status of choice, a glorious state of being, and conducive to permanent security and prosperity. Iran never strived for a clientelist status rather it viewed it as a fallback position, a point of departure, and a point from which to resurge. From the earliest days following the of the WWII, Iran was placed in the Northern Tier, therefore deserving an important place in the American strategic thinking. In fact, Iran was passively dragged into the new world order, as opposed to Saudi Arabia that actively strived to attain a parallel role and position. There is not enough evidence to argue that such a rift caused serious tensions in Saudi-Iranian relations before the Islamic Revolution; however, this variable played a significant role in defining the nature of Iranian-Saudi relations after 1979. There is no evidence suggesting any strong case of Iranian-Saudi security interconnectedness in this period as the real security concerns in both Tehran and Riyadh rested in (re)positioning their respective states in the post-WWII world order. During this period, Iran and Saudi Arabia both converged and diverged policies on a number of issues; however, the realities of the new era overshadowed these policy practices and neither gained momentum enough to influence patterns of amity and enmity. In fact, Iranian-Saudi encounters in this period, regardless of nature and outcome, were diluted, sporadic and episodic. 
The 1950s introduced the importance and relevance of two themes/layers of analysis for the Iranian-Saudi relations. First, both Iran and Saudi Arabia proved to be highly sensitive to major political events in adjacent regions and their spill-over effect on the Persian Gulf. This is yet another enduring element that has defined/impacted the nature of Iranian-Saudi relations in certain historical junctures. Second, the role and impact of domestically generated vulnerabilities - caused by the maladies of statesociety relations - in constraining foreign policy options and thereby defining foreign policy choices came to the fore. The Iranian-Saudi relations in the 1950s were impacted, more than anything, by Nasserism and the Israeli question. The case was made in the analysis of this period that the Iranian government perceived the Egyptian growing influence in the region primarily through pure Cold War geopolitical considerations. In the 1950s, Iran was primarily concerned with the Soviet Union and the Soviet-supported leftist Iranian opposition groups. In fact, Shah did not perceive Nasserist pan-Arabism as a threat on its own right, but he was concerned that this ideology could function as a vehicle for the expansion of the Soviet threat to the Persian Gulf region. On the other hand, the instability ingrained in the foundation of the Saudi polity (as discussed in chapter two) imposed certain choices and policies on the Saudis when dealing with the predicament of Nasserim became the order of the day. Unlike Iran and its pure geopolitical considerations with regard to Nasserism, Saudi Arabia had more reasons to feel apprehensive of Nasser's eastward move and ideological narrative. Nasser's suprastate identity of pan-Arabism was an existential challenge to Saudi Arabia's idea of the state. Exposure to Nasser's pan-Arabism as a strong supra-state source of identity placed Saudi rulers in a precarious situation. The pan-Arab ideals normatively pressured Arab 
states to adhere to ideals that were anathema to the state's sovereign status and independent foreign policy-making, an imposition that could shake the foundation of the infantile Saudi state. With such predispositions, Iranian pure geopolitical response to the challenge as witnessed in de facto recognition of Israel and close cooperation with this state in a variety of areas stood in contradistinction with Saudi's ambivalent response to this scenario. This divergence of policies went beyond straining Iranian-Saudi relations. Indeed, Riyadh — in line with the rest of the Arab world — turned anxious as to what Tehran's real intentions behind such a preference/policy were, an anxiety that was only reinforced when Iran joined the 1955 Baghdad Pact and decided to remain on the sidelines of the 1956 Suez Canal crisis. After a decade of dormancy, the 1950s witnessed a resurgence in Iranian-Saudi mutual construction of security perceptions and policies.

In the 1960s, Iran and Saudi Arabia experienced relatively amicable relations in spite of a variety of factors which could potentially distance the two states. Among the factors, one can note Iran's adamancy in maintaining ties with Israel, Iranian-Arab territorial disputes in anticipation of the British withdrawal from the region and a power vacuum created thereof, Iran's demonstrable regional assertiveness and its rapid military build-up, and contention over the sovereignty of Bahrain. Two factors convinced Iran and Saudi Arabia that pursuing cautious political ties, in spite of disagreements and differences, was vital to their interests. First, the threat of Nasser and his Pan-Arab ideology to the Persian Gulf region persisted into the 1960s; however, unlike the 1950s, this threat proved to be of positive impact on Iranian-Saudi relations thank to King Faisal's introduction of prudence to Saudi Arabia's foreign policy after almost a decade of disarray under King Saud's aegis. The second factor that kicked in the second half of 
the decade, was cooperative norms propagated by the Johnson administration's Persian Gulf policy in anticipation of the British withdrawal from the region. Despite ebbs and flows, Iran and Saudi Arabia sought to establish closer ties in order to coordinate their oil policies within the Organization of Petroleum Exporting Countries (OPEC), curb Nasser's moves in the region, and collaborate to maintain the regional peace and security. This partnership was of immense strategic importance for Mohammad Reza Shah to the point that he allegedly maintained that neither could theological differences undermine the Iranian-Saudi partnership nor Iranian-espoused Shiism was meant to overshadow the Saudi role in the Islamic world. This positive invocation of foundational theological differences constitutes the first and only instance where this notion was brought to the forefront of foreign policy rhetoric between the two states. Shiite-Sunni schism is commonly cited as one of the most important factor explaining the Iranian-Saudi difficult relations. In contrast to this suggestion, there is no evidence from the years covered in this study that corroborates that essentialist notion. Interestingly, the theological divide was never utilized in any securitizing language by either Iran or Saudi Arabia even in the heat of their most divisive tensions. In addition to that, the Shah of Iran had alluded that it does not intend to politicize the religious divide by any means. When in a symbolic visit to Saudi Arabia on June 3, 1968, Mohammad Reza Shah referred to King Faisal "Amir al-Muminin," he was clearly hinting Saudi Arabia that Shiite-Sunni divide did not need to be a determining factor in their interstate relations. In this period, mutual understanding between King Faisal and Mohammad Reza Shah about their common interests and their respective constraints helped them emerge from difficult times of the decade and overcome setbacks, join forces in launching regional initiatives such as Organization of 
the Islamic Conference, and set the stage for continued constructive political relations during the 1970s. At the outset of the first Islamic Summit, King Faisal and Mohammad Reza Shah entered together and received a standing ovation from an audience that included kings and presidents of the Islamic world. This positive image captures the essence of the Iranian-Saudi relations in this 1960s.

Iranian-Saudi relations continued with its remarkable growth into the 1970s due to the consolidating effect of the cooperative norms that the 1969 Nixon Doctrine set forth. During the latter half of the 1960s, Iran and Saudi Arabia learned how to cooperate in certain areas without letting their disagreements and rivalry negatively impact their relations. The Nixon Doctrine further solidified these relations. Nixon's Doctrine was slightly different from Johnson's Persian Gulf policy as it offered a greater role to Iran rather than Saudi Arabia. According to the documents, between 1969 and 1972, Mohammad Reza Shah aggressively lobbied Nixon to allow Iran fill the void left by the British withdrawal in the region. Accordingly, Nixon administration promoted Iran, and to a lesser extent Saudi Arabia, as guardians of regional security and as bulwarks against Soviet expansionism. This policy involved the provision of military armaments to these two key allies with the aim of achieving regional security. In spite of disparate American support for Iran, Tehran and Riyadh could align their policies and tacitly cooperate on many levels. Nevertheless, that cooperation did not spawn a radical change in the historical patterns of amity/enmity between the two states as Saudi Arabia and Iran never surmounted their mutually stigmatizing differences deeply embedded in their political cultures. In other words, while the facade of interactions between the two states in this decade alludes to cooperation, the convergence of policies between the two countries did 
not occur as the result of a genuine transformation in historical perceptions. The reason was the exacerbated Arab-Persian divide which was pushed to the back of geopolitical considerations, yet limiting the extent of an Iranian-Saudi integration. This ideational divide effectively stymied the prospect of transforming the communitarian norms of the decade into a functioning security community architecture. In other words, Iranian-Saudi relations overcame historical grievances, yet its further expansion was capped by ideational differences fundamentally dividing the two states along cultural fault-lines.

The cut-off point for this research was set at 1979 for greater intellectual consistency; nevertheless, the identified dynamics for the Iranian-Saudi Relations continued to define the nature of these relations in the decades to follow. The rift between Iran and Saudi Arabia came to complete rupture after other fault-lines were introduced to their relations after the revolutionary overhaul in the Iranian foreign policy. A snapshot of how these dynamics operated after 1979 is provided below. 


\section{Bibliography}

\section{$\underline{\text { Sources in Farsi }}$}

Abadian, Hossein. "Ghodrathaye bozorg va eshghale iran dar jange jahaniye dovvom," [Great

Powers and the Occupation of Iran during WWII], Tarikhe Ravabete Khareji, no. 28 (2006).

Adamiyat, Fereydoun. Andishehaye Mirza Agha Khan Kermani [The Ideas of Mirza Agha Khan Kermani] Tehran, Pirouz Publication, 1962.

Adamiyat, Fereydoun. Amir Kabir va Iran. [Amir Kabir and Iran] Tehran: Chap-e Ruz, 1954.

Afkhami, Gholamreza. "Moghaddame e bar enghelabe sefid," [An Introduction to the White Revolution] Iran Nameh, vol. 30, no. 1 (Spring 2015)

Afshar, Iraj. ed. Zendegi-ye Tufani: Khaterat-e Sayyed Hasan Taqizadeh, [Tumultuous Life: The Memories of Seyyed Hassan Taqizadeh] Tehran: Elmi, 1993.

Ahmadi, Hamid. ravabet iran va arabestan dar sadeh bistom: doreh pahlavi [Relations between Iran and Saudi Arabia in the Twentieth Century: Pahlavi Era]. Tehran: markaz chap va entesharat vezarat Oumur Kharejeh, 2007.

Akhundzadeh, Mirza Fath 'Ali. Maktubat-e Mirza Fath 'Ali Akhundzadeh, ed. M. Subhdam. Düsseldorf, Germany: Mard-e Imruz, 1985.

Akhundzadeh, Mirza Fath'Ali. Tamsilat: Seh Namayesh va Yek Dastan. Tehran: Entesharat-e Kharazmi, 1977.

Alaii, Mehdi. "Farayand e dolat va mellat sazi dar arabestan," [The Process of State Beuilding and Nation Building in Saudi Arabia] in Kamali, Hamidreza, The Middle East (9). Tehran: Abrar e Mo'aser.

Alikhani, A. yad dasht ha-yi asaddollah alam, [The Diaries of Alam], vol. 1, 1968-1969. Tehran: entesharat maziar va moin, 1998.

Arani, Taghi. Asar va Magalat [Collected Articles and Works]. Tehran, 1978.

Ashraf, Ahmad. "Hoviyat e Irani be se ravayat," [Iranian Identity, Three Narratives] Iran Nameh, vol. 24, no. 2 \&3 (Summer and Fall 2008)

Atabaki, Touraj. "Tanavvo e ghomi dar Iran va hoviyat e melli ye Iranian," [Ethnic Diversity in Iran and Iranian National Identity] Iran Nameh, vol. 24, no. $2 \& 3$ (Summer and Fall, 2008)

Ayromlou, Tajolmolouk. Khaterate tajolmoulk ayromlou [Memoirs of Pahlavi Queen, Tajolmlouk Ayromlou] Beh Afarin Publications, 2001.

Bahar, Mohammad-Taghi, Tarikh-e-Ahzab Siassi [The History of Political Parties]. Tehran, 1945.

Bayāt. Kaveh. ed., Fa 'ālīyathā-ye komūnīstī dar dawra-ye Rė̇ā Šāh, 1300-1310 [The Communist Activities in Iran during Reza Shah's Reign]. Tehran, 1992.

Bigdeli, Ali. "gharardad e 1975 e iran va araagh" [The 1975 Agreement Between Iran and Iraq] Tarikhe Ravabet Khareji, no.19 (2004).

Bigdeli, Ali. "farayande sheklgiriye kapitolasion va laghve aan dar iran" [Capitulations in Iran, Processes of Formation and Collapse] Tarikhe Ravabet Khareji, no. 18 (2004). 
Bigdeli, Ali “peyman e saadabad” [Saadabad Pact] Tarikhe Ravabete Khareji, no. 9 (2001)

Chamankar, Mohammad Jafar. "Ravabete iran ba oman dar doreye Pahlavi" [Iranian-Omani Relations during Pahlavi Era] Tarikhe Ravabete Khareji. no.16 (2003).

Chamankar, Mohammad Jafar. "degargooniye naghsh afarini e iran dar khalij e fars 1350-1357," [Shift in the Iranian Role in the Persian Gulf 1972-1979] Tarikhe Ravabete Khareji. no.22 (2005).

Chubineh, Bahram. ed. Mirza Aqa Khan Kermani: Seh Maktub [Three Letters]. 2000.

Dehghani, Hamidreza. "Nazari ba tasire mozou e nafte shoma va afzayesh nofuze amrika dar iran," [A Thought on the Impact of the Caspian Oil Controversy on the Increase of American Influence in Iran] Tarikhe Ravabete Khareji, no. 37 (2008).

Enayati, Alireza \& Zaki, Davud. "Payehahye mashrooi’yate siasi dar arabestan and noghate ghovvat va za'fe aan," [The Pillars of Political Legitimacy in Saudi Arabia: Strength and Weaknesses]. Tehran: Abrar e Mo'aser.

Entekhabi, Nader. "Nationalism and Tajaddod dat Farhang Siaisi after Mashrootiyat," [Nationalism and Modernization in Iran's Post-Constitutional Political Culture] Iran Nameh, vol.11, no.2 (Spring 1993)

Fakhrai. Ebrahim. Sardār-e jangal Mīrzā Kūček Kāan, Tehran: Javidan, 1972.

Farahmand, Ali. "Nagofteh haye emtiaz e d'arcy" [The Untold of the D'arcy Concession] Tarikhe Ravabete Khareji, no.29 (2006)

Fateh, Mostafa. Panjah Sal Naft e Iran [Fifty Years Iranian Oil] Tehran: Chehr Publication, 1956.

Ganjbakhsh Zamani, Mohsen. "Hozure almanihaye moghime iran: bahane I baraye eshale iran dar jange jahani dovvom," [The Presence of Germans in Iran: A Pretext for Occupying Iran During WWII] Tarikhe Ravabete Khareji, no.28 (2006).

Gharayaq-Zandi, D. Ir-aniy-an-e 'arab-tab-ar: mardom-shen'-asi-ye s $^{-} a k h t^{-}$ar-e qowmi-ye $a^{\prime} r^{-} a b-e$ khuzest ${ }^{-}$an [Iranians of Arab Origins: An Anthropology of the Ethnic Structure Among Khuzestan's Arabs], Tehran: Nashr-e Afkar, 2008.

Hajilou, Mohammad Ali, Rishehaye Tarikhi Tashayyo Dar Iran [Historical Roots of Shiism in Iran] Majma e Jahani Shia Shenasi, 2007.

Hedayat, M. Khaterat va khatarat [Memoirs and Dangers]. Tehran: Zawwar Press, 1984.

Jahanshahlou-Afshar. N. Ma va Biganegan: Sargozasht [The Foreigners and Us: The Story]. West Germany, 1982.

Karimi Hakkak, Ahmad. "Nejad, Mazhab, Zaban: Ta'ammoli dar se engareye ghomiyat dar Iran," [Race, Religion, Language: A Thought over the Three Elements of Iranian Ethnicity] Iran Nameh, vol.11, no.4 (fall, 1993).

Katouzian, Homa. Seyyed Hassan Taghizadeh, Se Omr Dar Yek Zendegi, [Seyyed Hassan Taqizadeh: Three Lives in One Lifetime] Iran Nameh, vol.21, no. 3 \& 4. (Summer, Spring 1993)

Khonji, Amir Hossein. "Sabegheye tarikhi e eskan e ashayer e Arab dar khuzestan," [The History of Accommodation of Arab Tribes in Iran]. Persian Gulf Studies. 
Koohestaninejad, Masoud. "mokatebat e abdolhasan teymourtash va robert clive" [Correspondence between Abdolhasan Teymourtash and Robert Clive] Tarikhe Ravabete Khareji, no. 21 (2004).

Koohestaninejad, Masoud. "ravabeteh iran va Israel dar doreye dolate dr. mosaddegh" [IranianIsraeli Relations During Dr. Mosaddeq's Administration] Tarikhe Ravabete Khareji, no. 15 (2003)

Makki Hossein. Tarikh-e Bist Saley-e Iran [Twenty Years' History of Iran]. 7 vols. Tehran: Nashr Publishing Co., 1983.

Matini, Jalal. "Bahsi Darbare ye Sabeghe ye Tarikhi ye Alghab va Anavin e Olama Dar Mazhab e Shia," [A Historiography of Titles Used for Ulema in Shiism] Iran Nameh.

Mirza Saleh, Gholam Hossein. Bist Sal Ba Reza Shah, Khaterat-e Soleiman Behbudi [Twenty Years with Reza Shah, Memoires of Soleiman Behbudi]. Tarhe No. 1993.

Mohaghegh, Ali. asnad ravabet iran va arabestan saudi (1304-1357) [Documents of Relations between Iran and Saudi Arabia (1925-1979)] . Tehran: Entesharat Vezarat Oumur Kharejeh, 1379/2000-2001.

Mohammadzadeh, Hamid. ed. Akhundzadeh, Alefba-e Jadid va Maktubat, Tabriz: Ehya Publications, 1978.

Mojtahed-Zadeh, Pirooz. "Regional Alliance in the Persian Gulf: Past Trends and Future Prospects." Iranian Journal of International Affairs 10 (1998)

Mojtahed-Zahed, Pirooz. Security and territoriality in the Persian Gulf: A Maritime Political geography. Routledge, 2013.

Mo’memi, Baqer. ed. Maqalat. Tehran: Ava Press, 1972.

Motahari, Morteza. Khadamat e Moteghabel e Eslam va Iran [Mutual Contributions of Islam and Iran,] Sadra Publication, 1987.

Pahlavi, Ashraf. Chehrehayi dar Ayeneh [Faces in the Mirror, Memoires from the Exile] Tehran: Nashr va Pajoohesh Farzan Rooz, 1998.

Parsi Nejad, Iraj. "Mirza Agha Khan Kermani," Iran Nameh, vol. 8, no.4 (Fall 1990).

Pishgahifard, Zahra \& Mirahmadi, Soghra. "Tahlil e tarikhi geopolitiki e ravabet e iran va mesr as jange jahani dovvom ta enghelabe eslami," [A Historical-Geopolitical Analysis of Iranian-

Egyptian Relations From WWII through the Islamic Revolution]. Tarikh e Ravabete Kharejii, no. 40, (2009)

Pour Bakhtiar, Ghaffar. "Khaneine bakhtiari, dolat e englis va siasathaye nafti," [Bakhtiari Tribes, Britain and Oil Policies] Tarikh e Ravabet e Khareji, no. 41, 2009.

Shoomij, Mohammad. "barresiye tatbighiye ravabete roosiye e tazari va shoravi by nehzate jangal," [Comparative Study of the Relations of Tsarist Russia and Soviet Union with the Jangali Movements] Tarikhe Ravabet Khareji, no. 30 (2008). 
Soleimani, Karim. "monasebate farhangiye iran va arabestan dar beyne salhaye 1345 va 1355," [Iranian-Saudi Cultural Relations, 1966-1976] Tarikhe Ravabete Khareji, no. 21 (2004).

Tooyserkani, Mojtaba. "Iran va jame e ye melal" [Iran and the League of Nations] Tarikhe Ravabete Khareji, no. 24/25 (2005).

Qajar, Jalal al-Din Mirza. Nameh-ye Khosravan, vol. 1. Tehran, 1869.

Yegikian, G. Showravi va Jonbeshi Jangal: Yaddashthayi Yek Shahedi Eyni [The Soviet Union and the Jangali Movement: Writings of an Eyewitness]. Novin Publishing Organization, 1984.

Zahedi, Ardeshir, Khaterat e Ardeshir Zahedi [Memoires of Ardeshir Zahedi] Maryland, Ibex Publishers, 2010.

Zera'at Pisheh, Najaf. Barovord e strategic e arabestan Saudi [A Strategic Assessment of Saudi Arabia] Tehran, Abrar e Mo'aser, 2007.

\section{$\underline{\text { Sources in English }}$}

Aarts, Paul \& Nonneman, Gerd. Saudi Arabia in the balance: Political economy, society, foreign affairs. NYU Press. 2005.

Abrahamian, Ervand. Iran between Two Revolutions. Princeton: Princeton University Press, 1982.

Acharya, A. "The emerging regional architecture of world politics" World Politics, 59, 4 (2007) 629-652.

Acharya, A., \& Johnston, A. I. Crafting cooperation: Regional international institutions in comparative perspective. Cambridge University Press, 2007.

Adelson, Roger. London and the Invention of the Middle East: Money, Power, and War, 19021922. Yale University Press, 1995.

Adib-Moghaddam, Arshin. The international politics of the Persian Gulf: A cultural genealogy Routledge, 2006.

Adler, Emanuel \& Barnett, M. Security Communities. Cambridge University Press, 1998.

Adler, Emanuel "Imagined (security) communities: Cognitive regions in international relations." Millennium-Journal of International Studies, 26, 2, (1997) 249-277.

Adler, Emanuel \& Barnett, M. "A framework for the study of security communities." Cambridge Studies in International Relations, 62 (1998) 29-66. 
Afary, Janet. The Iranian Constitutional Revolution, 1906-1911: Grassroots Democracy. Columbia University Press, 1996.

Afkhami, Gholamreza. The life and times of the Shah. University of California Press, 2009.

Afrasiabi, Kaveh. L., After Khomeini: New directions in Iran's foreign policy. Westview Press Boulder, CO. 1994.

Agabekov, G. S. OGPU, the Russian Secret Terror. Brentano's, 1931.

Aghaie, Kamran S., \& Afshin Marashi. Rethinking Iranian Nationalism and Modernity. University of Texas Press, 2014.

Ahmadi, Hamid. "Unity within diversity: foundations and dynamics of national identity in Iran." Critique: Critical Middle Eastern Studies 14, no. 1 (2005): 127-147.

Ahmadi, Kourosh. Islands and international politics in the Persian Gulf: The Abu Musa and Tunbs in strategic context. Routledge, 2008.

Albaharna, Husain M. The legal Status of the Arabian Gulf States: a study of their treaty relations and their international problems. Manchester University Press, 1968.

Aldamer, Shafi. Saudi Arabia and Britain: Changing Relations, 1939-1953. Ithaca, 2003.

Al-Kahtani, Mohammad Zaid. The Foreign Policy of King Abdul Aziz (1927-1953): A Study in the International Relations of an Emerging State (diss.)

Al-Rasheed, Madawi. "The Shi'a of Saudi Arabia: a minority in search of cultural authenticity." British Journal of Middle Eastern Studies 25, no. 1 (1998)

Al-Rasheed, Madawi. ed. Transnational connections and the Arab gulf. Routledge Research in Transnationalism. London, Routledge, 2004.

Al-Rasheed, Madawi. A history of Saudi Arabia. Cambridge University Press, 2010.

Al-Saud, Faisal bin Salman. Iran, Saudi Arabia and the Gulf: Power Politics in Transition. IB Tauris, 2003.

Alvandi, Roham. "Muhammad Reza Pahlavi and the Bahrain Question, 1968-1970." British Journal of Middle Eastern Studies, 37.2 (2010) 159-177.

Amirahmadi, Houshang \& Nader Entessar, eds. Iran and the Arab world. Springer, 1993.

Amirsadeghi, Hossein. (ed.), The Security of the Persian Gulf. London, Croom Helm, 1981.

Anderson, Benedict. Imagined communities: Reflections on the origin and spread of nationalism. Verso Books, 2006.

Ansari, Ali M. Modern Iran since 1921: The Pahlavis and After. Pearson Education. 2003.

Ansari, Mustafa. The history of Khuzistan, 1878-1925: a study in provincial autonomy and change. University of Chicago, 2005.

Anthony, John D. "The Persian Gulf in Regional and International Politics: the Arab Side of the Gulf," in Hossein Amirsadeghi (ed.), The Security of the Persian Gulf. London, Croom Helm, 1981. 
Anthony, John D. "Aspects of Saudi Arabia's Relations with Other Gulf States," in Timothy Niblock, State, Society and Economy in Saudi Arabia. Routledge, 2015.

Askari, Hossein, Mohseni, Amin, \& Daneshvar, Shahrzad. The militarization of the Persian Gulf: An economic analysis. Edward Elgar Publishing. 2010.

Atabaki, Touraj. Iran and the First World War: Battleground of the Great Powers, ed. London: I. B. Tauris, 2006.

Axworthy, Michael. A history of Iran: Empire of the mind. Basic Books, 2010.

Bacevich, Andrew. J. "The real world war IV.” The Wilson Quarterly (1976-) 29.1. (2005) 36-61.

Bacevich, Andrew. J. The limits of power: The end of American exceptionalism. Macmillan, 2008 .

Bacevich, Andrew. J. Washington rules: America's path to permanent war. Macmillan, 2010.

Bacevich, Andrew. J. The new American militarism: How Americans are seduced by war. Oxford University Press, 2013.

Badeeb, Saeed. M. Saudi-Iranian Relations 1932-1982. London: Centre for Arab and Iranian Studies and Echoes, 1993.

Baram, Philip. J. The Department of State in the Middle East, 1919-1945. University of Pennsylvania Press. 1978.

Barkan, Leonard. Unearthing the Past: Archaeology and Aesthetics in the Making of Renaissance Culture. New Haven, Yale University Press, 1999.

Barthold, V. V. An Historical Geography of Iran, trans. Soucek, S. Princeton, NJ: Princeton University Press, 1984.

Barzegar, K. “Iran's foreign policy in post-invasion Iraq” Middle East Policy, 15.4 (2008) 47-58.

Bausani, A. The Persians, from the Earliest Days to the Twentieth Century. St. Martin's Press, 1971.

Bayne, Ashley E. "Crisis of confidence in Iran.” Foreign Affairs, 29.4 (1951) 578-590.

Beeson, M. "Rethinking Regionalism: Europe and East Asia in Comparative Historical Perspective," Journal of European Public Policy, 12.6 (2005): 969-985.

Beling, Willard A. (ed.), King Faisal and the Modernization of Saudi Arabia, London: Croom Helm, 1980.

Bellamy, Alex J. Security communities and their neighbors. Regional fortresses or global integrators? Palgrave MacMillan, 2004.

Beloff, Baron M. The Foreign Policy of Soviet Russia 1929-1941. Vol. 2. 1936-1941. Oxford University, 1955. 
Bennett, A. 'The mother of all "isms": Organizing political science around causal mechanisms.' in Ruth Groff, Revitalizing Causality: Realism about Causality in Philosophy and Social Science Routledge, 2007. 205-219.

Berbeglou, Berch. Nationalism and Ethnic Conflict: Class, State and Nation in the Age of Globalization, Rowman and Littlefield, Lanham, 2006.

Bhagwati, Jagdish. "Regionalism and Multilateralism: An Overview," New dimensions in regional integration 22 (1993).

Bill, James A. "Resurgent Islam in the Persian Gulf." Foreign Affairs 63, no. 1 (1984): 108-127.

Bohlen, Charles. E. Witness to history, 1929-1969. WW Norton \& Company, 1973.

Boroujerdi, Mehrzad. "Triumphs and travails of authoritarian modernization in Iran." in Stephanie Cronin, The Making of Modern Iran: State and Society under Riza Shah, 1921-1941. Routledge, 2003.

Boroujerdi, Mehrzad. “After Khomeini: New directions in Iran's foreign policy” The Middle East Journal, 50.2 (1996)

Brecher, Michael. Decisions in Israel's Foreign Policy. New Haven, Conn., 1975.

Bromley, Simon. American hegemony and world oil: The industry, the state system and the world economy. Penn State Press, 1991.

Browne, Edward. G., \& Abbas Amanat. The Persian Revolution of 1905-1909. F. Cass. 1966.

Brysac, Shareen. B. "A very British coup: how Reza Shah won and lost his throne," World Policy Journal, 24.2 (2007) 90-103.

Buchan, James. "Secular and Religious Opposition in Saudi Arabia," in Timothy Niblock, State, Society and Economy in Saudi Arabia, Routledge, 2015.

Burns, William. J. Economic aid and American policy toward Egypt, 1955-1981. SUNY Press, 1985.

Burrell, Robert. M. The Persian Gulf. New York, Library Press, 1972.

Burrell, Robert M., and Jarman, Robert. Iran: Political Diaries, 1881-1965, Cambridge University Press, 1997.

Buzan, Barry. and Ana Gonzalez-Palaez ed., International Society and the Middle East: English School Theory at the Regional Level, Palgrave Macmillan UK, 2009.

Buzan, Barry. People, States \& Fear: an Agenda for International Security Studies in the PostCold War Era. Ecpr Press, 2008.

Buzan, Barry, \& Wæver, Ole. "Macrosecuritization and security constellations: Reconsidering scale in securitization theory" Review of International Studies, 35.2 (2009) 253-276.

Buzan, Barry, \& Weaver, Ole. Regions and powers: The structure of international security. Cambridge: Cambridge University Press, 2003. 
Buzan, Barry, Wæver, Ole, \& de Wilde, Jaap. Security: A new framework for analysis. Boulder, Colorado: Lynne Rienner Publication, 1998.

Byman, Daniel. L., \& Wise, John R. The Persian Gulf in the Coming Decade: Trends, Threats, and Opportunities, Rand Corp. Santa Monica, 2003.

Byrne, Malcolm. "The road to intervention: Factors influencing US policy toward Iran, 19451953." Gasiorowski, M. J., \& Byrne, M. eds. Mohammad Mosaddeq and the 1953 coup in Iran. Syracuse University Press. 2004. 201-226.

Byron, Robert. The road to Oxiana. Random House, 2010.

Cantori L.J. \& Spiegel, S.L. "The analysis of regional international politics: The Integration versus the empirical systems approach.” International Organization, 27.4, (1970) 465-494.

Cantori L.J. \& Spiegel, S.L. The international politics of regions. Englewood Cliffs, N.J: Prentice-Hall, 1970.

Chaqueri, Cosroe. "Sultanzade: the forgotten revolutionary theoretician of Iran: a biographical sketch”. Iranian Studies, 17, 2-3 (1984): 215-235

Chaqueri, Cosroe. Avetis Sultanzade, the Forgotten Revolutionary Theoretician. Antidote Publications, 1985.

Chaqueri. Cosroe. The Conditions of the Working Class in Iran, Florence, 1978.

Checkel, J.T. "Process tracing." In D. Prakash, \& A. Klotz, Qualitative methods in international relations. Palgrave Macmillan UK, 2008. 114-127.

Checkel, J.T. "Tracing causal mechanisms." International Studies Review 8, no. 2 (2006) 362370.

Childers, E. The Road to Suez. MacGibbon \& Kee. 1962.

Childs, J. R. Foreign Service Farewell: My Years in the Near East. University of Virginia Press, 1969.

Childs, James Rivs. Trans. Perso-Russian Treaty and Notes 1828-1931. 1935.

Chubin, Shahram and Sepehr Zabih, the Foreign Relations of Iran: A Developing State in a Zone of Great Power Conflict. Berkeley, CA: University of California Press, 1974.

Chubin, Shahram and Tripp C. Iran-Saudi Arabia Relations and Regional Order. No. 304.

Routledge, 2014.

Chubin, Shahram. Iran's national security policy: Intentions, capabilities, and impact. Washington, D.C.: Carnegie Endowment for International Peace, 1994.

Chubin, Shahram \& Litwak, R. S. Debating Iran's nuclear aspirations. Washington Quarterly, 26.4 (2003) 99-114. 
Churchill, W. The world crisis, 1911-1918. Simon and Schuster, 2005.

Cleveland W.L. \& Bunton, M.P. A History of the Modern Middle East. ed. Westview, 2012.

Coakley, Robert W. The Persian Corridor as a Route for Aid to the USSR. Center for Military History, 1990.

Cohen, B. "The political economy of currency regions." The political economy of regionalism 50 (1997).

Cole, J. "The United States and Shi'ite religious factions in post-Ba'athist Iraq." The Middle East Journal, (2003) 543-566.

Cole, J. R., \& Keddie, N. R. Shi'ism and social protest. Yale University Press, 1986.

Cooley, J. Unholy wars: Afghanistan, America and international terrorism. Pluto Press, 2002.

Cooper, A. F. Niche diplomacy: Middle powers after the cold war. Basingstoke: Macmillan, 1997.

Cooper, A. The oil kings: how the US, Iran, and Saudi Arabia changed the balance of power in the Middle East. Simon and Schuster, 2012.

Cordesman, Anthony H. (1997). Bahrain, Oman, Qatar, and the UAE: Challenges of security. Boulder, Colorado: Westview. 1997.

Cordesman, Anthony H., \& Gold, B. The Gulf military balance: The missile and nuclear dimensions. Rowman \& Littlefield. 2014.

Cottam, R. W. Nationalism in Iran. University of Pittsburgh Press, Pittsburgh, 1964.

Cottrell, A. J., Bosworth, C. E., \& Burrell, R. M. The Persian Gulf states: A general survey. Johns Hopkins University Press. 1980.

Cronin, Stephanie. "Building a New Army: Military Reform in the Qajar Era," in Farmanfarmaian, R. War and Peace in Qajar Persia: Implications Past and Present. London: Routledge, 2008.

Cronin, Stephanie. The Making of Modern Iran: State and Society under Riza Shah, 19211941. Routledge, 2003.

Crosbie, S. K. A tacit alliance: France and Israel from Suez to the Six Day War. Princeton University Press, 2015.

Crystal, J. Oil and politics in the Gulf: Rulers and merchants in Kuwait and Qatar. Cambridge University Press. 1995.

Dahl, E. J. Naval innovation: from coal to oil. National Defense University, Washington DC Institute for National Strategic Studies, 2001. 
Dailami, P. "The populists of Rasht: Pan-Islamism and the role of the Central Powers," in

Atabaki, T. Iran and the First World War: Battleground of the Great Powers, ed. London: I. B. Tauris, 2006.

Dame, L. "Four Months in Nejd," The Muslim World, 14.4 (1924) 353-362.

Darwin, J. "Britain, the Commonwealth and the End of Empire," $B B C$.

Daryaee, Touraj. "National history or Keyanid history? The nature of Sasanid Zoroastrian historiography." Iranian Studies 28, no. 3-4 (1995): 129-141.

Dawisha, A.I. Saudi Arabia's Search for Security. Adelphi Papers, no. 158. 1979.

Dawisha. A. (ed.), Islam in Foreign Policy, Cambridge University Press, 1983.

De Gaury, Gerald. Faisal: King of Saudi Arabia, New York: Frederick A. Praeger Publishers, 1967.

Deese, D. A., \& Nye, J. S. (1981). Energy and security. Ballinger Pub Co.

Dennis, A. L. P. The Foreign Policies of Soviet Russia. Dent \& Sons, 1924.

DeNovo, John A. American Interests and Policies in the Middle East, 1900-1939. Minneapolis: University of Minnesota Press, 1963.

Dickson, H.R.P. The Arab of the Desert. A Glimpse into Badawin Life in Kuwait and Sau'di Arabia. Routledge, 2015.

Dockrill, S. Britain's Retreat from East of Suez: the Choice between Europe and the World? Palgrave Macmillan, 2002.

Doran, M. S. “The Saudi paradox.” Foreign Affairs, (2004) 35-51.

Dunnigan, J. F., \& Macedonia, R. M. Getting it right: American military reforms after Vietnam to the Persian Gulf and beyond. New York: W. Morrow and Co. 1993.

Ehteshami, A. "Iran-Iraq relations after Saddam.” Washington Quarterly, 26.4 (2003) 115-129.

Eisenhower, Dwight D. The White House Years, 1956-61: Waging Peace. Garden City, N.Y., 1965 .

Elling, R. C. Minorities in Iran: Nationalism and Ethnicity after Khomeini. Palgrave Macmillan, 2013.

Elphinston, W. G. “The Kurdish Question.” International Affairs, 22, 1 (1946)

Elwell-Sutton, L.P. Persian Oil: A Study in Power Politics. London: Lawrence, 1955.

Entesar, N. "The Lion and the Sphinx: Iranian-Egyptian Relations in Perspective" in Hooshang Amirahmadi, and Nader Entessar, eds. Iran and the Arab world. Springer, 1993.

Entessar, N. "Changing Patterns of Iranian-Arab Relations," Journal of Social, Political and Economic Studies, Vol. 9, no. 3 (Fall 1984).

Ethier, W. J. “The New Regionalism,” The Economic Journal, 108, 449 (1998): 1149-1161. 
Farmanfarmaian, R. War and Peace in Qajar Persia: Implications Past and Present, ed. London: Routledge, 2008.

Farrokh, K. Iran at War: 1500-1988. Osprey Publishing, 2011.

Fateh, M. Fifty years of Iranian oil. Tehran, Chehr stock company, 1956.

Fawcett, L. "Exploring Regional Domains: A Comparative History of Regionalism." International Affairs, 80.3 (2004) 429-446.

Fawcett, L.L. and Hurrell, A. eds. Regionalism in world politics: regional organization and international order. Oxford University Press, 1995.

Fawcett, Louise. Iran and the Cold War: the Azerbaijan Crisis of 1946, Cambridge: Cambridge University Press, 1992.

Fawn, R. "'Regions' and their study: wherefrom, what for and whereto?." Review of International Studies 35, no. S1 (2009): 5-34.

Ferrier, R.W \& Bamberg, J. H. The History of the British Petroleum Company. Cambridge University Press, Cambridge. 1982.

Ferrier, Ronald. "The Iranian Oil Industry," in Avery, P, Gavin Hambly, and Charles Melville. ed. The Cambridge History of Iran. Cambridge University Press, 1991. 7: 639 - 701

Finer, Herbert. Dulles over Suez: The Theory and Practice of His Diplomacy. Chicago, 1964.

Finlayson, J. A., Zacher, M.W. "The United Nations and Collective Security" in Tobi T. Gati, The US, the UN and the Management of Global Change. New York: New York University Press, 1983.

Fisher, J.A. Records by Admiral of the Fleet, Lord Fisher. Hodder and Stoughton, 1919.

Foran, J. A Century of Revolution: Social Movements in Iran, ed. University of Minnesota Press, 1994.

Fox, J. W., Mourtada-Sabbah, N., \& Al Mutawa, M. Globalization and the Gulf. Routledge. 2006.

Frank, A. G. "Third world war: A political economy of the Gulf war and the new world order." Third World Quarterly13, no. 2 (1992): 267-282.

Frank, L. P. (1985). “The first oil regime.” World politics, 37(4), 586-598.

Fraser, C. "In Defense of Allah's Realm: Religion and Statecraft in Saudi Foreign Policy Strategy," in Susanne H. Rudolf and James Piscatori (eds.), Transnational Religion and Fading States. Boulder: Westview, 1997.

Freedman, L., \& Karsh, E. The Gulf conflict, 1990-1991: Diplomacy and war in the new world order. Princeton, N.J.: Princeton University Press. 1993. 
Frye, R.N. "The political history of Iran under the Sasanians." The Cambridge History of Iran 3, no. 1 (1983): 116-180.

Fuller, Graham and Franke, R.R. The Arab Shia: The Forgotten Muslims. New York: Palgrave, 1999.

Gaddis, J. L. (2005). Strategies of containment: a critical appraisal of American national security policy during the Cold War. Oxford University Press.

Garthoff, Raymond L. Detente and Confrontation: American Soviet Relations from Nixon to Reagan. Washington, DC. Brookings Institutions, 1994.

Gasiorowski, Mark J. "US foreign policy toward Iran during the Mussadiq era," in David Lesch, The Middle East and the United States (ed.) Boulder, CO: Westview press, 2006.

Gasiorowski, M. J. US foreign policy and the shah: building a client state in Iran. Cornell University Press, 1991.

Gasiorowski, M. J., \& Byrne, M. (Eds.). Mohammad Mosaddeq and the 1953 coup in Iran. Syracuse University Press, 2004.

Gause, Gregory. "Illogic of dual containment," Foreign Affairs. (1994)

Gause, Gregory. The international relations of the Persian Gulf. Cambridge University Press. 2009.

Gause, Gregory. "British and American Policies in the Persian Gulf 1968-1973," Journal of International Affairs 45.2 (1985).

Gause, Gregory. Saudi-Yemeni Relations: Domestic Structures and Foreign Influence. Columbia University Press, 1990.

George, A.L., and Andrew Bennett. Case studies and theory development in the social sciences. (MIT Press, 2005)

Gerring, J. "Single-outcome studies: A methodological primer." International Sociology 21, no. 5 (2006): 707-734.

Ghani, C. Iran and the Rise of the Reza Shah: From Qajar Collapse to Pahlavi Power. IB Tauris, 2000 .

Gherado Gnoli, The idea of Iran: an essay on its origin. Rome, 1989.

Ghods, M. R. "The Iranian Communist Movement under Reza Shah.” Middle Eastern Studies, 26.4 (1990): 506-513

Giddens, Anthony. The nation-state and violence. University of California Press, 1985.

Giddens, Anthony. Modernity and Self-Identity. New York: Polity Press, 1991.

Glaser, Charles \& Rosemary Kelanic, Crude Strategy. Washington D.C. Georgetown University Press, 2016. 
GoGwilt, C.L. "The geopolitical image: imperialism, anarchism, and the hypothesis of culture in the formation of geopolitics." Modernism/modernity 5, no. 3 (1998): 49-70.

Goldberg, Jacob. The foreign policy of Saudi Arabia: The formative years, 1902-1918 (No. 19). Cambridge, Harvard University Press, 1986.

Golub, D. When Oil and Politics Mix: Saudi Oil Policy, 1973-1985. No. 4. Harvard University Center Middle Eastern, 1985.

Gordon, M. Conflict in the Persian Gulf. Springer, 1981.

Gordon, M. R., \& Trainor, B. E. The generals' war: The inside story of the conflict in the Gulf. (Boston Mass.: Little, Brown. 1995)

Gormly, J. L. "Keeping the Door Open in Saudi Arabia: The United States and the Dhahran Airfield, 1945-46”. Diplomatic History, 4.2 (1980) 189-206.

Grayson, B. Saudi-American Relations. Washington: University Press of America, 1982.

Graz, L. The turbulent Gulf. IB Tauris. 1990.

Griffiths, L. Permeable boundaries in Africa. African Boundaries, Barriers, Conduits and Opportunities. London \& New York, Pinter, 1996.

Gunder Frank, Andre "Capitalism and underdevelopment in Latin America; historical studies of Chile and Brazil" (1969).

Gunther, John, Inside Asia. Harper, 1939.

Haas, E.B. "The study of regional integration: reflections on the joy and anguish of pretheorizing." International Organization 24, no. 4 (1970): 606-646.

Halabi, Y. (2009). US Foreign Policy in the Middle East: From Crisis to Change. Ashgate Publishing, Ltd.

Hall, S. Yemen: The politics of unity. London: Gulf Centre for Strategic Studies. 1991.

Halliday, Fred. The Middle East in international relations: power, politics and ideology (Vol. 4). Cambridge University Press, 2005.

Harper, T. “Japan's Gigantic Second World War Gamble,” The Guardian, 2009.

Heikal, Mohamed. The Cairo documents: the inside story of Nasser and his relationship with world leaders, rebels, and statesmen. Doubleday, 1973.

Heikal, Mohamed. The Ayatollah's Guns: The Story of Iran and the Revolution. Beirut: Dar alShorouq, 1982.

Heikal, Mohamed. The Sphinx and the Commissar. New York, 1976.

Helms, Christine. M. The Cohesion of Saudi Arabia. Routledge, 2015.

Herrmann, R.K., and Ayres, R. W. The New Geo-Politics of the Gulf: Forces for Change and Stability. St. Martin's Press, 1997. 
Hettne, B. "Globalization and the New Regionalism: The Second Great Transformation." Globalism and the New Regionalism, 1(1999): 1-24.

Hinnebusch, Raymond. The international politics of the Middle East. Manchester University Press, 2010.

Hiro, D. Iran under the Ayatollahs. Routledge, 2013.

Hobsbawm. Eric. Nations and nationalism since 1780: programme, myth, reality. Cambridge University Press, 1990.

Holden, D., \& Johns, R. The house of Saud. Sidgwick \& Jackson, 1981.

Holm, H.H. and Sørensen, G. Whose world order? Uneven Globalization and the End of the Cold War. Westview Press, 1995.

Holsti, K.J. The state, war, and the state of war. Cambridge University Press, 1996.

Hoopes, Townsend. The Devil and John Foster Dulles. Little, Brown, 1973.

Hopkirk, Peter. On Secret Service east of Constantinople: The Plot to Bring down the British Empire. Oxford University Press, 2001.

Hopkirk, Peter. The Great Game: The Struggle for Empire in Central Asia. New York: Kodansha International, 1994.

Hudson, Michael C. "To Play the Hegemon: Fifty Years of US Policy towards the Middle East", Middle East Journal 50.3 (1996)

Hunter, Robert. E. Building Security in the Persian Gulf. Santa Monica, CA: RAND, 2010.

Hunter, Shireen. T. "The Soviet Union and the Islamic Republic of Iran.” in Malik, H. SovietAmerican Relations with Pakistan, Iran and Afghanistan. Palgrave Macmillan UK. 1987.

Hunter, Shireen T. Iran divided: the historical roots of Iranian debates on identity, culture, and governance in the twenty-first century. Rowman \& Littlefield, 2014.

Hurewitz, J. "The Persian Gulf: British withdrawal and Western security." The Annals of the American Academy of Political and Social Science, 401.19 (1972) 106-115.

Hurewitz, J. C. ed. Diplomacy in the Near and Middle East: 1914-1956 (Vol. 2). Van Nostrand, 1956.

Hurewitz, J. C. ed. The Middle East and North Africa in World Politics: A Documentary RecordBritish-French Supremacy, 1914-1945 (Vol. 2). Yale University Press, 1979.

Hurewitz, J. C. The Middle East and North Africa in World Politics, 2 vols. (New Haven, Ct. 1975)

Hurrell, Andrew. "Regionalism in theoretical perspective" in L. L. Fawcett, \& A. Hurrell, eds., Regionalism in world politics. Oxford University Press, 1995. 
Hurrell, Andrew \& Fawcett, L. L. "Regionalism and international order?" in Andrew Hurrell, \& L. L. Fawcett, eds. Regionalism in world politics: Regional organization and international order. Oxford University Press, 1995.

Ibn Khaldun, The Muqaddimah: an introduction to history, 3 vols. Princeton University Press, 1969.

International Monetary Fund (IMF) International Statistics Yearbook, Washington.

Izraeli, S. The Remaking of Saudi Arabia: The Struggle between King Sa'ud and Crown Prince Faysal, 1953-1962 (Vol. 121). Syracuse University Press, 1997.

Jackson, R.H. Quasi-states: Sovereignty, international relations, and the third world. (Cambridge: Cambridge University Press. 1990)

James Sontang, Raymond and James Stuart Beddie, eds. Nazi-Soviet Relations, 1939-1941:

Documents from Archives of the German Foreign Office. Washington DC: Department of State, 1948.

Jervis, Robert. "Security regimes." International organization, 36, no. 2 (1982): 357-378.

Jones, D., \& Smith, M. L. "Constructing communities: The curious case of East Asian regionalism." Review of International Studies, 33.1 (2007) 165-186.

Jones, S. The Archaeology of Ethnicity: Constructing Identities in the Past and Present, Routledge, London. 1997.

Jones, T.C. "Rebellion on the Saudi Periphery: Modernity, Marginalization, and the Shia Uprising of 1979." International Journal of Middle East Studies 38, no. 2 (2006): 213-233

Joshua, W., \& Gibert, S. P. Arms for the Third World: Soviet military aid diplomacy. Johns Hopkins University Press, 1969.

Juergensmeyer, M. "Rethinking the Secular and Religious aspects of Violence," in Craig Calhoun, Mark Juergensmeyer, and Jonathan Van Antwerpen. Rethinking secularism. Oxford University Press, 2011.

Kacowicz, A. M. Zones of peace in the third world: South America and West Africa in comparative perspective. Suny Press, 1998.

Kahtani, M. The Foreign Policy of King Abdul Aziz (1927-1953): A Study in the International Relations of an Emerging State (Diss).

Kaiser, K. "The interaction of regional subsystems: Some preliminary notes on recurrent patterns and the role of superpowers," World Politics, 21, (1968) 84-107.

Kamrava, Mehran. International politics of the Persian Gulf. Syracuse University Press. 2011.

Kaplan, Robert .D. The revenge of geography: what the map tells us about coming conflicts and the battle against fate. Random House, 2012.

Karanjia, R. K. The Mind of a Monarch. Allen \& Unwin, 1977. 
Karsh, E., and Karsh, I. Empires of the Sand: The Struggle for Mastery in the Middle East, 17891923. Harvard University Press, Cambridge, 2001.

Kashani-Sabet, F. "Cultures of Iranianness: The Evolving Polemic of Iranian Nationalism", in Keddie N. and Rudi Matthee, eds., Iran and the Surrounding World. Interactions in Culture and Cultural Politics,. Seattle, WA: University of Washington Press, 2002.

Katzenstein, Peter. J. "Re-examining Norms of Interstate Relations in the New Millennium," Kuala Lumpur: Paper for the 14th Asia-Pacific Roundtable, 2000.

Katzenstein, Peter. J. A world of regions: Asia and Europe in the American imperium, Cornell University Press, 2005.

Kawtharani, W. and Khair el-Din Haseeb. "Mutual awareness between Arabs and Iranians." Arab-Iranian Relations. Beirut: Centre for Arab Unity Studies, 1998.

Kazemzadeh, F. "Iranian relations with Russia and the Soviet Union," in The Cambridge History of Iran. Vol. 7: From Nadir Shah to the Islamic Republic (1991) 314-342.

Kazemzadeh, M. "Tribal Politics in Iran: Rural Conflict and the New State, 1921-1941." Middle Eastern Studies, 44.1 (2008) 153-157.

Kearns, Gerry. Geopolitics and empire: The legacy of Halford Mackinder. Oxford University Press, 2009.

Kechichian, Joseph. ed. Succession in Saudi Arabia. Springer, 2001.

Kechichian, Joseph. Faysal: Saudi Arabia's king for all seasons. University Press of Florida, 2008.

Keddie Nikkei and Rudi Matthee, eds., Iran and the Surrounding World. Interactions in Culture and Cultural Politics, Seattle, WA: University of Washington Press, 2002.

Keddie, Nikkei R., \& Yann Richard. Modern Iran: Roots and results of revolution. Yale University Press, 2006.

Keefer, Edward C. \& Patterson, David, Foreign Relations of the United States, 1964-1968. Washington, United States Government Printing Office, 2000.

Keller, E. "Rethinking African Regional Security." Regional Orders: Building Security in a New World (1997): 296-317.

Kennan, G. F. (1946). “The sources of Soviet conduct.” Foreign Affairs, 25, 566.

Kennedy, Edward M. "The Persian Gulf: Arms Race or Arms Control?" Foreign Affairs 54, no. 1 (1975): 14-35.

Kennedy, Paul M. The Rise and Fall of the Great Powers: Economic Change and Military Conflict from 1500 to 2000 (1987)

Keohane, Robert. "State Power and Industry Influence: American Foreign Oil Policy in the 1940s". In International Organization. Vol., 36. No. 1, (Winter, 1982) 165- 183. 
Keohane, Robert \& Joseph S. Nye Jr. "Between centralization and fragmentation: the club model of multilateral cooperation and problems of democratic legitimacy." John F. Kennedy School of Government Working Paper. Harvard University, 2001.

Keylor, W. R. The twentieth-century world. Oxford University Press, 1992.

Keynoush, Banafsheh. Saudi Arabia and Iran: Friends or Foes? Springer, 2016.

Khomeini. Roohollah. Islam and Revolution: Writings and Declarations of Imam Khomeini (1941-1980). BookBaby, 2015.

Kim, S. S. "Northeast Asia in the local-regional-global nexus: Multiple challenges and contending explanations." The International Relations of Northeast Asia, 41 (2004).

Kinzer, S. Overthrow: America's century of regime change from Hawaii to Iraq. Macmillan, 2007.

Kissinger, Henry. The White House Years. London: Weidenfeld \& Nicolson, 1979.

Kissinger, Henry. Years of Upheaval. London: Weidenfeld and Nicolson, 1982.

Kitson, M., \& Michie, J. Trade and Growth, a Historical Perspective: From Managing the Global Economy. Oxford University Press. 1995.

Knights, M. "Saudi Arabia faces long-term insecurity." Janes Intelligence Review. 16 (2004): 1621.

Kostiner, J. The making of Saudi Arabia, 1916-1936: From chieftaincy to monarchical state. Oxford University press, 1993.

Koury, E. M., and Nakhleh, E. A. eds. The Arabian Peninsula, Red Sea, and Gulf: Strategic Considerations. Institute of Middle Eastern \& North African Affairs, 1979.

Kraig, Michael Ryan. "Forging a new security order for the Persian Gulf." Middle East Policy 13, no. 1 (2006): 84.

Kramer, M. S. Shi'ism, resistance, and revolution. Westview Press, 1987.

Krasner, Stephen D. Defending the national interest. Princeton: Princeton University Press, 1978.

Krock, A. Memoirs: 60 Years on the Firing Line. Funk \& Wagnalls, 1968.

Kuhns, Woodrow J. ed., Assessing the Soviet Threat: The Early Cold War Years. Washington DC: Center for the Study of Intelligence, CIA, 1997.

Kuniholm, B. R. The origins of the Cold War in the Near East: Great power conflict and diplomacy in Iran, Turkey, and Greece. Princeton University Press, 2014.

Kupchan, Charles. A., Kupchan, Clifford .A. "Concerts, collective security, and the future of Europe." International Security 16, no. 1 (1991): 114-161. 
Kupchan, Charles. The Persian Gulf and the West: The dilemmas of security. Boston: Allen \& Unwin. 1987.

Lackner, H. A House Built on Sand: A Political Economy of Saudi Arabia, London: Ithaca Press, 1978.

Lake, David A. and Morgan, Patrick M. Regional orders: Building security in a new world. University Park: Penn State University Press. 1997.

Lawson, F. Constructing international relations in the Arab world. Stanford University Press, 2006.

Leffler, Melvyn P. A Preponderance of Power: National Security, the Truman Administration and the Cold War. Stanford University Press, 1993.

Legrenzi, M. Security in the Gulf. Routledge, 2013.

Lenczowski, George. The Middle East in world affairs. Cornell University Press, 1980.

Lenczowski, George. Russia and the West in Iran, 1918-1948. NY: Cornell University Press, 1949.

Litvak, M. Constructing Nationalism in Iran: From the Qajars to the Islamic Republic.

Routledge, 2017.

Long, David E. Persian Gulf: an introduction to its peoples, politics, and economics. Routledge, 1976.

Louer, L. Transnational Shia politics: religious and political networks in the Gulf. Columbia University Press, 2008.

M.B. "British Interests in the Persian Gulf" Bulletin of International News vol. 18, No. 19 (1941) 1193-1198.

Mackey, Sandra, The Iranians: Persia, Islam and the Soul of a Nation. Penguin Group, 1996.

Mackinder, H.J. "The geographical pivot of history." Royal Geographical Society. (1904).

Majd, M.G. Great Britain and Reza Shah: The Plunder of Iran, 1921-1941. University Press of Florida, Gainesville, 2001.

Makki, Hossein. The History of Twenty Years, Vol.2, Preparations for Change of Monarchy. Mohammad-Ali Elmi Press, 1945.

Malik, H. ed. Soviet-American Relations with Pakistan, Iran and Afghanistan. Springer, 1987.

Mamdani, M. Good Muslim, bad Muslim: America, the Cold War, and the roots of terror. Harmony, 2005.

Mangold, P. Superpower intervention in the Middle East. Routledge, 2013. 
Mansfield, Edward D., \& Milner, Helen V. The political economy of regionalism. New York: Columbia University Press, 1997.

Mansfield, Edward D. \& Milner, Helen V. "The New Wave of Regionalism." International organization 53, no. 3 (1999): 589-627.

Mansoor, M. Political and Diplomatic History of the Arab World, 1900-1967: A Chronological Study, University of Michigan Press, Ann Arbor, 1972.

Maoz, Z. Regional security in the Middle East: Past present and future. Routledge, 2013.

Marashi, Afshin. Nationalizing Iran: culture, power, and the state, 1870-1940. University of Washington Press, 2011.

Marcussen, M. "The dynamics of EMU ideas." Cooperation and Conflict 34, no. 4 (1999): 383411.

Mark, Eduard, "Revolution by Degrees: Stalin's National-Front Strategy for Europe, 1941-1947," Cold War International History Project, Working Paper no. 31, Woodrow Wilson International Center for Scholars, Washington DC, Feb. 2001.

Mark, Eduard. "The War Scare of 1946 and Its Consequences," Diplomatic History 21, no. 3 (summer 1997): 383-415

Marschall, C. Iran's Persian Gulf policy: From Khomeini to Khatami. Routledge. 2003.

Martin W. Lewis, Karen Wigen. The Myth of Continents: A Critique of Metageography. University of California Press, 1997.

Martin, Vanessa. Creating an Islamic State: Khomeini and the Making of a New Iran. London: I. B. Tauris, 2000.

Marx, A.W. Faith in nation: exclusionary origins of nationalism. Oxford University Press, 2005.

Mastanduno, M. "A realist view: Three images of the coming international order." International Order and the Future of World Politics, 1990, 19-40.

McCuen, Gary E. Iran Iraq War. Gem Publications, 1987.

Mearsheimer, J. J. "Back to the future: Instability in Europe after the cold war." International Security, 15, no. 1 (1990) 5-56.

Mearsheimer, John. The tragedy of great power politics, WW Norton \& Company, 2001.

Mehran, G. 'The Presentation of the "Self" and the "Other" in Post-revolutionary Iranian School Textbooks,' in Keddie and Mathee (eds), Iran and the Surrounding World. Interactions in Culture and Cultural Politics, Seattle, WA: University of Washington Press, 2002.

Meinig, D. W. "Culture blocs and political blocs: Emergent patterns in world affairs" Western Humanitarian Review, 10 (1956) 203-222. 
Merrill, D., \& Paterson, T. Major Problems in American Foreign Relations, Volume II: Since 1914 (Vol. 2). Cengage Learning, 2009.

Meskoob, Shahrokh. Iranian Nationality and the Persian Language, trans. Washington, DC: Mage, 1992.

Metz, H. C. Persian Gulf States. USGPO, 1994.

Meyer, Gail E. Egypt and the United States: The Formative Years. Rutherford, NJ: Fairleigh Dickinson University Press. 1980.

Miles, S. B. The countries and tribes of the Persian Gulf. Garnet. 1994.

Miller, A. Search for Security: Saudi Arabian Oil and American Foreign Policy, 1939-1949. Chapel Hill: University of North Carolina Press, 1980.

Mirhosseini, S. M., \& Sandhu, S. K. "The role of Iran regarding the US security systems in the Persian Gulf region.” Cross-Cultural Communication, 6.4 (2011) 121-134.

Mittelman, J. H., and Falk. R. "Hegemony: The Relevance of Regionalism?" National Perspectives on New Regionalism in the North 175 (1999).

Mitzen, Jennifer. "Ontological security in world politics: State identity and the security dilemma." European Journal of international relations, 12, 3 (2006): 341-370

Morgan, Patrick M. "Regional Security Complexes and Regional Orders," in David Lake and Patrick Morgan, ed. Regional Orders: Building Security in a New World. Penn State University Press, 1997. 20-42.

Moshaver, Z. "The international relations of the Persian Gulf." Journal of Arabian Studies, 2.2 (2012) 242-243.

Mostyn, T. Major Political Events in Iran, Iraq, and the Arabian Peninsula, 1945-1990. Facts on file, (1991)

Motter, Vail. The Persian Corridor and Aid to Russia. Washington D.C. Center for Military History, 1952.

Mueller, C. "Anglo-Iranian Treaty Negotiations: Reza Shah, Teymurtash and the British Government, 1927-32,” Iranian Studies, 49.4 (2016) 577-592

Mughisuddin, M. Conflict and cooperation in the Persian Gulf. Praeger Publishers, 1977.

Murden, S. "Secondary Institutions of Regional Interstate Society," in Barry Buzan and Ana Gonzalez-Palaez (ed.), International Society and the Middle East: English School Theory at the Regional Level. Palgrave Macmillan UK, 2009.

Murphy, A. B. "Regions as social constructs: The gap between theory and practice." Progress in Human Geography, 15.1 (1991) 23-35. 
Nakash, Y. The Shi 'ism of Iraq. Princeton University Press, 2003.

Nakhleh, E. A. The Persian Gulf and American policy. New York, N.Y: Praeger, 1982.

Nasr, Vali. "Regional implications of Shi'a revival in Iraq." Washington Quarterly, 27.3 (2004) 5-24.

Neff, D. Warriors at Suez: Eisenhower Takes America into the Middle East. Amana Publications, 1988.

Neumann, I.B. Uses of the other:" the East" in European identity formation. vol. 9. Minneapolis: University of Minnesota Press, 1999.

Niblock, Tim. ed. State, Society and Economy in Saudi Arabia. Routledge, 2015.

Niblock, Tim. Saudi Arabia: Power, legitimacy and survival. Routledge, 2004.

Nicolson, H. Curzon: The Last Phase 1919 1925. London, 1934.

Öjendal, J. "Back to the future? Regionalism in South-East Asia under unilateral pressure." International Affairs, 80.3 (2004) 519-533.

Olson, R. Islamic and Middle Eastern Societies, ed. Brattleborough, VT, 1987.

O'Neill, B. E., \& Kass, I. “The Persian Gulf War: A political-military assessment.” Comparative Strategy, 11.2 (1992) 213-240.

Orgill, A. The 1990-91 Gulf war: Crisis, conflict, aftermath: An annotated bibliography. London; New York: Mansell, 1995.

Osterud, O. "Review Essay: The Uses and Abuses of Geopolitics." Journal of Peace Research 25, no. 2 (1988): 191-199.

Pahlavi, Mohammad Reza, Answer to History. New York: Stein and Day, 1980.

Parsi. Trita. Treacherous alliance: the secret dealings of Israel, Iran, and the United States. Yale University Press, 2007.

Peck, M. "The Saudi-American Relationship and King Faisal." in Willard A. Beling (ed.), King Faisal and the Modernization of Saudi Arabia. London: Croom Helm, 1980.

Pelletiere, Stephen C. The Iran-Iraq war: chaos in a vacuum. ABC-CLIO, 1992.

Pervin, D. J. "Building Order in Arab-Israeli Relations: From Balance to Concert." Regional orders: Building security in a new world (1997): 271-95.

Peterson, J. Defending Arabia. Routledge, 2016.

Peterson, J. E. "Britain and The Oman War: An Arabian entanglement," Asian Affairs, 7.3 (1976) 285-298 
Peterson, J. E. Saudi Arabia and the illusion of security. Routledge, 2013.

Philby, St. John H. Saudi Arabia. Ernest Benn. 1955

Piscatori, James "Islamic Values and National Interest: The Foreign Policy of Saudi Arabia," in Adeed Dawisha (ed.), Islam in Foreign Policy, Cambridge University Press, 1983.

Poliakov, Leon. The Aryan Myth: A History of Racist and Nationalist Ideas in Europe. Plume, 1977.

Pollard, R. A. Economic security and the origins of the Cold War: 1945-1950. Columbia University Press, 1985.

Potter, L. G. Security in the Persian Gulf: Origins, obstacles, and the search for consensus. Macmillan, 2002.

Powell, William. Saudi Arabia and Its Royal Family, New Jersey: Lyle Stuart, Inc., 1982

Quandt, W. B. Saudi Arabia in the 1980s: Foreign policy, security, and oil. Brookings Institution Press, 1981.

Ra'anan, Uri. The USSR Arms the Third World: Case Studies in Soviet Foreign Policy.

Cambridge, Mass. 1969.

Rajaee, Farhang. ed. The Iran-Iraq war: the politics of aggression. University Press of Florida, 1993.

Ramazani, R. K “Iran and the Arab-Israeli Conflict," Middle East Journal (1978)

Ramazani, R. K. Iran's Foreign Policy, 1941-1973: A Study of Foreign Policy in Modernizing Nations. Charlottesville: University Press of Virginia, 1975.

Ramazani, R. K. The Persian Gulf; Iran's role. Charlottesville: University Press of Virginia. 1972.

Rashidvash, V., \& Jafari, M. J. "Iranian People and the Race of People Settled in the Iranian Plateau," JHSS (2012).

Ravenhill, J. "East Asian regionalism: Much ado about nothing?" Review of International Studies, 35.S1 (2009) 215-235.

Reno, W. "Clandestine economies, violence and states in Africa." Journal of International Affairs-Columbia University, 53.2. (2000) 433-460.

Resis, Albert (ed.) Molotov Remembers: Inside Kremlin Politics, Conversations with Felix Chuev. Chicago: Ivan R. Dec.1993.

Rezun, M. The Soviet Union and the Iran: Soviet Policy in Iran from the Beginnings of the Pahlavi Dynasty until the Soviet Invasion in 1941. Vol. 8. Brill Archive, 1981.

Rice, Talbot D. "Introduction” in Byron, R. The Road to Oxiana. Random House, 2010. 
Ricks, T. M. "Slaves and slave traders in the Persian Gulf, $18^{\text {th }}$ and $19^{\text {th }}$ centuries: an assessment," Slavery and Abolition, 9.3 (1988) 60-70.

Riedel, B. "Brezhnev in the Hejaz." The National Interest 115 (2011): 27-32.

Risse, T., Engelmann-Martin, D., Knope, H., \& Roscher, K. "To euro or not to euro? The EMU and identity politics in the European union." European Journal of International Relations, 5.2 (1999) 147-187.

Rose Greaves, R. "Iranian Relations with Great Britain and British India, 1798-1921," in The Cambridge History of Iran, 7 (1991) 374-425.

Rosecrance, Richard. "Regionalism and the Post-Cold War Era." International Journal 46, no. 3 (1991): 373-393.

Rudolf, S. and James Piscatori (eds.), Transnational Religion and Fading States, Boulder:

Westview, 1997.

Rupert, M. Producing hegemony. Cambridge University Press, 1995.

Russett, B.M. International regions and the international system: A study in political ecology. Chicago: Rand McNally. 1967.

Safran, N. From War to War: The Arab-Israeli Confrontation, 1948-1967; a Study of the Conflict from the Perspective of Coercion in. Pegasus, 1969.

Safran, N. Saudi Arabia: The Ceaseless Quest for Security. NY: Cornell University Press, 1985.

Samore, Gary. "The Persian Gulf," in David A. Deese and Joseph S. Nye (eds.), Energy and Security, Cambridge: Ballinger Publishing Company, 1981.

Sampson, A. The seven sisters: the great oil companies and the world they shaped. Bantam, 1991.

Sato, S. "Britain's Decision to Withdraw from the Persian Gulf, 1964-68: A Pattern and a Puzzle," Journal of Imperial and Commonwealth History, 37.1 (2009) 99-117.

Sciolino, E. The outlaw state: Saddam Hussein's quest for power and the gulf crisis. John Wiley \& Sons Inc. 1991.

Seton-Watson, H. "An enquiry into the origins of nations and the politics of nationalism." Nations \& States.: 563 (1977)

Shahibzadeh, Y. The Iranian Political Language: From the Late Nineteenth Century to the Present. Palgrave MacMillan, 2015.

Shimshoni, J. Conventional deterrence: lessons from the Middle East. Princeton University Press, 1986.

Sick, Gary. The evolution of US strategy toward the Indian Ocean and Persian Gulf regions. The Great Game: Rivalry in the Persian Gulf and South Asia. New York: Praeger, 1983.

Sicker, Martin. The Bear and the Lion: Soviet Imperialism and Iran. New York: Praeger, 1988. 
Sloan, G. "Sir Halford J. Mackinder: the heartland theory then and now." The Journal of Strategic Studies 22, no. 2-3 (1999): 15-38.

Sloan, G. and Colin S. Gray. "Why geopolitics?" The Journal of Strategic Studies 22, no. 2-3 (1999): 1-11.

Smith, A.D. The antiquity of nations. Wiley, 2004.

Sobhani, S. The Pragmatic Entente: Israeli-Iranian Relations, 1948-1988. NewYork: Praeger, 1989.

Solingen, E. "Economic liberalization, political coalitions, and emerging regional orders." in Louise L. Fawcett, and Andrew Hurrell, eds. Regionalism in world politics: regional organization and international order. Oxford University Press, 1995. 68-100

Solingen, E. Regional orders at century's dawn: Global and domestic influences on grand strategy. Princeton University Press, 1998.

Soucek, S. “Arabistan or Khuzestan”. Iranian Studies, 17. 2 -3 (1984) 195-213.

Spykman, N. J., \& Rollins, A. A. “Geographic Objectives in Foreign Policy, II.” American Political Science Review, 33, 04 (1939) 591-614.

Steele, Brent. J. Ontological security in international relations: self-identity and the IR state. Routledge, 2008.

Stein, A. and Steven E. Lobell, "Geostructuralism and international politics: the end of the Cold War and the regionalization of international security" in David A. Lake and Patrick M. Morgan, Regional Orders: Building Security in a New World. University Park: Pennsylvania State University Press, 1997. 101-122.

Stock, Ernest. Israel on the Road to Sinai 1949-1956. Ithaca. N. Y.: Cornell University Press 1967.

Stookey, R. W. America and the Arab States: An Uneasy Encounter (Vol. 4). John Wiley \& Sons, 1975.

Strunk, W. "Britain, Persia, and Shaykh Khaz'al: The genesis of a special relationship." in Roger Olson, Islamic and Middle Eastern Societies, ed. Brattleborough, VT, 1987. 152-71.

Sykes, C. Four studies in loyalty. Collins, 1946.

Taheri, Amir. "Policies of Iran in the Persian Gulf region," in Abbas Amirie, The Persian Gulf and Indian Ocean in International Politics, Tehran: Institute for International Politics and Economic Studies, 1975. 259-286.

Tapper, R. "The case of the Shahsevan." in Stephanie Cronin, The Making of Modern Iran: State and Society under Riza Shah, 1921-1941 (Routledge, 2003)

Teitelbaum, J. "The Shiites of Saudi Arabia." Current Trends in Islamist Ideology 10 (2010): 72.

Thesiger, W. Arabian sands. Penguin, 2007.

Thomas, H. The Suez Affair. Weidenfeld \& Nicolson, 1967. 
Trautmann, Thomas R. Aryans and British India. Berkeley: University of California Press, 1997. Trento, J. Prelude to Terror: Edwin P. Wilson and the Legacy of America's Private Intelligence Network. Basic Books, 2009.

Trigger, Bruce G. A History of Archaeological Thought. Cambridge University Press, 1989.

Tripp, Charles \& Chubin, Shahram. Iran and Iraq at war. IB Taurus, 1988.

Troeller, G. The Birth of Saudi Arabia. F. Cass, 1976.

Truman, Harry S. Memoirs by Harry S. Truman: Years of Trial and Hope (2 Vols.). Doubleday, 1956.

Tuathail, G.O. and Gerard Toal. Critical geopolitics: The politics of writing global space. vol. 6. University of Minnesota Press, 1996.

Turner, B.S. "A sociology of citizenship and human rights." in Rhiannon Morgan and Bryan S.

Turner, eds. Interpreting Human Rights. London: Routledge, 2009. 177-199.

Tweedy, O. Cairo to Persia and Back. Jarrolds, limited, 1933.

Ullman, R.H. The Anglo-Soviet Accord. Princeton University Press, 1972.

Van Evera, Stephen. Guide to methods for students of political science. Ithaca: Cornell University Press. 1997.

Vassiliev, A. The History of Saudi Arabia (Saqi, 2013)

Väyrynen, R. "Stable peace through security communities? Steps towards theory building." Stable Peace among Nations, (2000).

Wæver, Ole, Lemaitre, Pierre, \& E. Tromer, eds., European polyphony: Beyond East-West confrontation. London: Macmillan, 1989.

Wæver, Ole. Concepts of security. University of Copenhagen, Institute of Political Science, 1997.

Weaver, Ole "Societal Security: The Concept," in Ole Weaver and et al. Identity, Migration and the New Security Agenda in Europe. London, Pinter 1993. 17-40.

Weaver, Ole, et al. Identity, Migration and the New Security Agenda in Europe. London, Pinter 1993.

Wahbah, Ḥ. Arabian days. London, Barker, 1964.

Walt, S. M. The origins of alliance. Cornell University Press, 1990.

Waltz, Kenneth. Theory of International Politics. Waveland Press, 1979.

Ward, S. R. Immortal: A Military History of Iran and Its Armed Forces, Georgetown University Press, 2014.

Waterfield, G. Professional Diplomat, Sir Percy Loraine, Murray, London, 1973. 
Weller, M., Iraq and Kuwait: The hostilities and their aftermath. Cambridge: Grotius Publications, 1993.

Wendt, Alexander. Social theory of international politics. Cambridge: Cambridge University Press, 1999.

Whigham, H.J. The Persian Problem. Isbister and Company Limited, 1903.

Wilber, Donald N. Riza Shah Pahlavi: the resurrection and reconstruction of Iran. Hicksville, NY: Exposition Press, 1975.

Wilkinson, J. C. "The Oman question: The background to the political geography of Southeast Arabia," Geographical Journal, (1971) 361-371

Wilson, A. The Persian Gulf. Routledge, 2011.

Winters, L. A. Regionalism vs. Multilateralism. Market Integration, Regionalism and the Global Economy. World Bank Publications, 1999.

Wohlforth, William C. "The stability of a unipolar world." International security, 24, no. 1 (1999): 5-41.

Wolfers, Arnold, "The Goals of Foreign Policy." Readings on the International Political System, Englewood Cliffs-NJ (1970).

Woodward, E. L. British foreign policy in the Second World War. HM Stationery Office, 1962.

Wriggins, W. H. Dynamics of regional politics: Four systems on the Indian Ocean rim. Columbia University Press, 1992.

Wright, D. The English amongst the Persians: during the Qajar period 1787-1921. I.B. Taurus, 2001.

Yamani, M. Cradle of Islam: The Hijaz and the quest for an Arabian identity. I.B. Taurus, 2009.

Yapp, M. E. The Near East since the First World War: A History to 1995. Routledge, 2014.

Yarshater, E., ed. The Cambridge History of Iran. vol. 3. Cambridge University Press, 1983.

Yazdi, L.P. "What He Thought... What He Did: An Archaeological Study of the Persian Gulf Coasts Colonial Sites of Sheikh Khazal Khan in the Early Twentieth Century." International Journal of Historical Archaeology, 17, 1 (2013)

Yegorova, N. I. The" Iran crisis" of 1945-1946: a view from the Russian archives (No. 15). Cold War International History Project, Woodrow Wilson International Center for Scholars, 1996.

Yergin, Daniel. The prize: The epic quest for oil, money \& power. Simon and Schuster, 2011.

Yergin, Daniel. Shattered Peace: The Origins of the Cold War and National Security State. Houghton Mifflin, 1977.

Yodfat, A. The Soviet Union and Revolutionary Iran. Taylor \& Francis, 2010. 
Zabih, S. The communist movement in Iran. University of California Press, 1966.

Zdanowski, J. Slavery and Manumission: British Policy in the Red Sea and the Persian Gulf in the first half of the $20^{\text {th }}$ Century. Ithaca Press, 2012.

Zirinsky, M. P. "The rise of Reza Khan.” in John Foran, A Century of Revolution: Social Movements in Iran, ed. University of Minnesota Press, 1994. 44-77.

Zirinsky, M. P. "Imperial Power and Dictatorship: Britain and the Rise of Reza Shah, 19211926.” International Journal of Middle East Studies, 24, 4 (1992) 639-663. 


\section{NIMA BAGHDADI}

- Born, Tehran, Iran.

- 1999-2003, B.A., English Translation, Azad University- Tehran South Branch, September 1999-September 2003

- 2003-2007, M.A., International Relations, Allameh Tabatabee University

- 2010- 2013, M.A., Political Science, Department of Politics and International Relations, FIU

- 2010-Present, Ph.D., Political Science, Department of Politics and International Relations Florida International University [Dissertation: Dynamics of IranianSaudi Relations in the Persian Gulf Regional Security Complex (1920-1979)

Publications and Presentations

- "Soft Power or Hard Power: Rethinking the United States Foreign Policy in the Arab Middle East," Journal of International and Global Studies, (Spring Issue, April, 2017)

- $\quad$ "Iranian-Saudi Relations in the 1930s: A Curious Case of "Disregard" in Foreign Policy," ISSS-ISAC, Washington, DC. 2017

- "Saudi Arabia and the Question of Stability: A Normative Discussion of Sovereignty," ISA, Baltimore, Maryland, 2017

- "Iran's National Security: Exaggerated Threat of Ethnoreligious Minorities," ISA, Baltimore, Maryland, 2017

- 'Saudi Arabia's Raison D'etre: A Challenge to the Authority of the House of Saud," Journal of International and Global Studies, (7. No. 2, 2016)

- "The Idea of the Saudi State and the Centrifugal Sources of Identity in Saudi Arabia," ISA Midwest, St. Louis, Missouri, 2016

- "The Security Dynamics of Saudi-Iranian Relations: Debunking the Myth of Religious/Racial Divide," ISA Midwest, St. Louis, Missouri, 2016

- “How Saudi Arabia's Raison D’etre Plays into Its Domestic Insecurity," ISA Northeast, Baltimore, Maryland, 2016

- "Domestic Sources of Insecurity within the Littoral States to the Persian Gulf: Regional Security Implications", Midwest Political Science Association, MPSA, Chicago 2016

- "Network of American Foreign Think Tanks", with Hamid Serri, Midwest Political Science Association, MPSA, Chicago, 2014

- How Diplomatic Processes Fail: Case of Iran's Nuclear Program from a Sociopolitical Perspective" with Naisy Sarduy, International Studies Association, ISA, Toronto 2014 
- $\quad$ "Demographic Change and National Security Culture: Iran and Inevitable Transformation of its National Security Strategy" with Saeed Mousavi, , Midwest Political Science Association, MPSA, Chicago 2013

- "Elite Conflict and the US-Iran Relations", International Studies Association, ISA, San Francisco 2013

- $\quad$ Diffusion of Democracy: Normative Encounter of Democratic Narrative of Governance and the Alternatives", International Studies Association, ISA, San Francisco, 2013

- "Prospective Construction of Identity and its Ramifications", International Studies Association , North East Division, ISA NE, Providence, 2013

- "Evolution of Warfare, Dehumanization and Ethics", International Studies Association, North East Division, ISA NE, Providence 2013

- "Secularism Revisited: State as the New Church", American Sociological Association, ASA, Denver, 2012

- "State as a Unitary Actor?: Iran Shaping an Anomaly", Middle East Studies Association, MESA, Denver, 2012 